Historic, archived document

Do not assume content reflects current scientific knowledge, policies, or practices. 



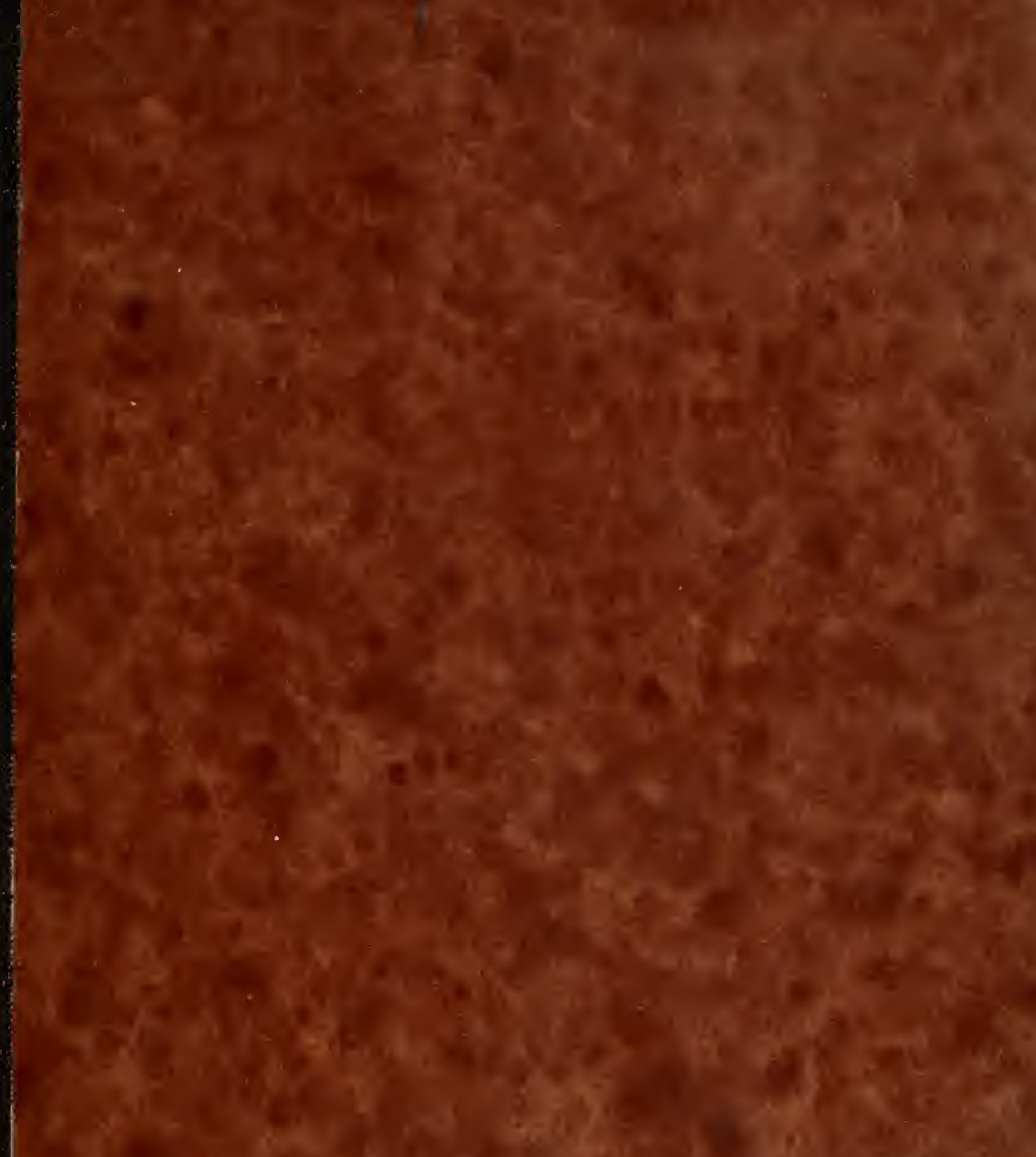




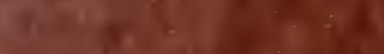

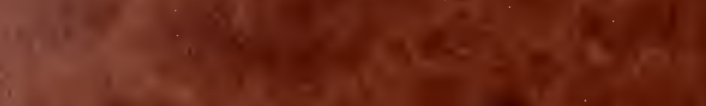

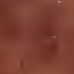

i

$(-1)$

itis: $=4$

2

$\therefore$

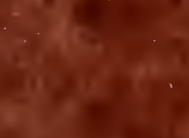

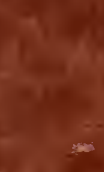

$-2 \quad 3$

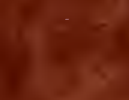

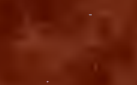

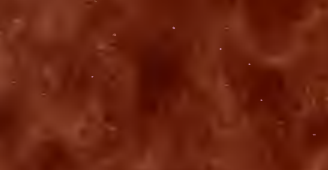

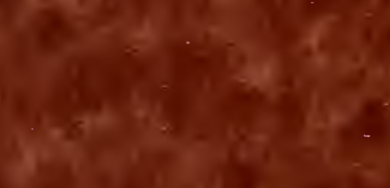

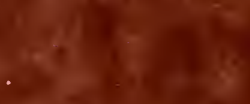

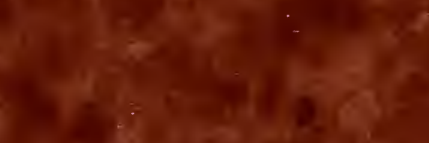

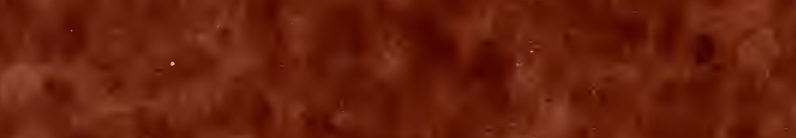

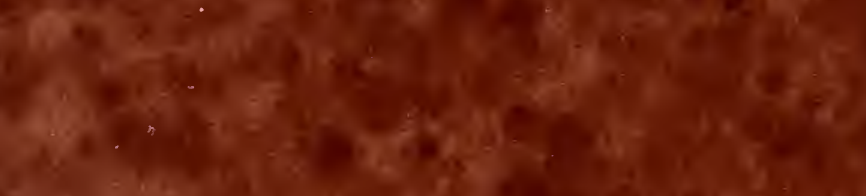

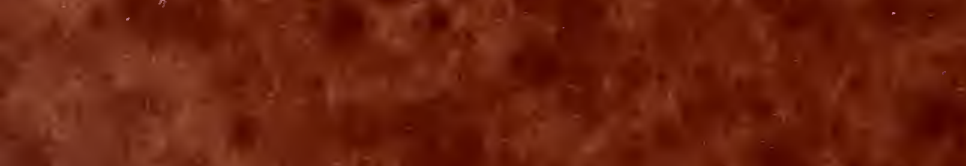

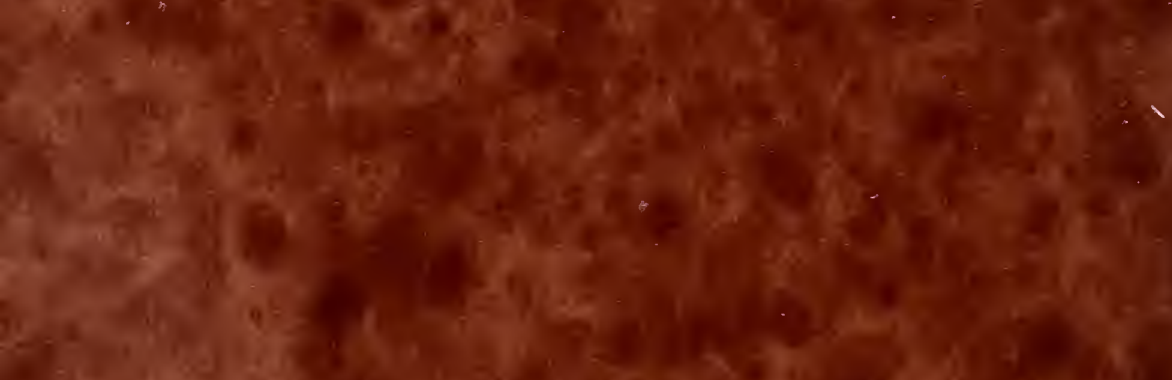

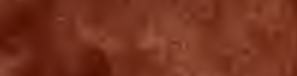

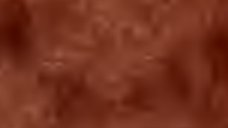

the

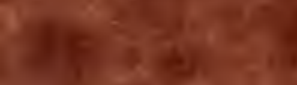

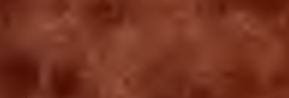

4.

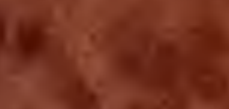

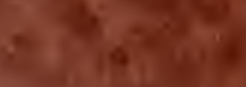

$y^{2}+1$

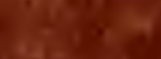

$\ln _{2}+$

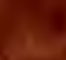

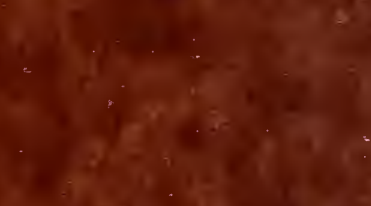

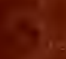

$x^{-4}=$ 
blars 93 ase 11 .

$2 e_{4}$

Lovett's

Elustrated Catalogue

of ruit and Ornamental

Yrees and Plants

for the Autumn p 1891:

2.2. Lovett Company, Litusilver, h. L. 


\section{ADVICE AND TERMS.}

Remit by Money Order on RED BANK, N. J., Registered Letter, Draft, or Express Money Order. Please do not send private checks. Address all letters, J. T. LOVETT CO., LITTLE SILVER, N. J.

Payments invariably in advance.-Goods sent C. O. D., only when one-fourth the amount is sent with order, with charges for returning money added to bill.

Orders. - Small favors thankfully received always, but we cannot undertake to fill an order of less amount than one dollar as the cost of recording and flling the same would exceed the amount received.

How to order.-Be sure to write your name and address plainly-give Post Offlce, County and State-and do this every time you write us; always state distinctly the size and grade of articles ordered, as quoted in the Catalogue; also be particular to say always how the goods are to be sent; whether by mall, express or freight. When these conditions are not complied with, we use our judgment as to size and ship by the way we deem best. Keep a correct copy of the order and check off the stock when it arrives; people often forget what they order and make unjust complaint.

Prices of this catalogue abrogate previous quotations and are for the autumn of 1891 only. The prices affixed are for the quantities specifled, but half dozen, flfty and flve hundred of a variety will be supplied at dozen, hundred and thousand rates respectively. With apples, pears, peaches and other FRDIT TREES, fifty in assorted varieties of a class may be ordered at hundredrates and five hundred at thousand rates; but hundred lots of strawberries, raspberries and other SMALL FruiTs cannot be made up at hundred rates, of less than flfty of a variety, and thousand lots cannot be made up at thousand rates, of less than five hun-

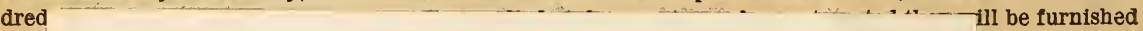
at tr

IIRIAIRY

OF THE

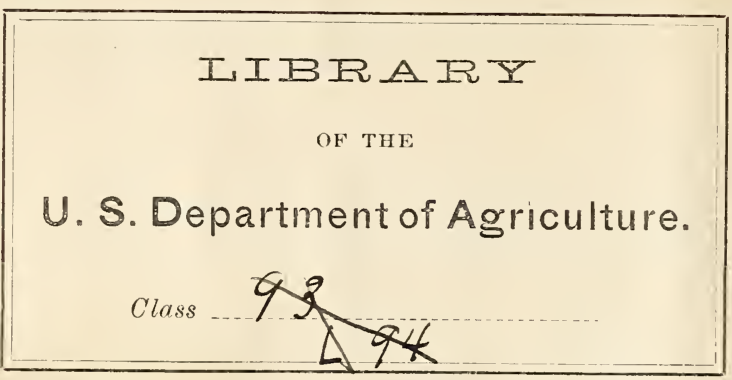

Pla lat should any le for damages r years continue

tereby reducing belled.

control ceases, be prepaid and io cover freight to what point cbaceous plants

zes of Trees or

rfully examined and, if just, all made satisfactory. Claims made after fffteen days from receipt of goods will not be entertained. We send out only good stock in good condition, freshly dug and carefully packed, in all cases, but success or failure depends in so large a degree upon the weather and the care and management after received, that we do not, because we cannot, undertake to guarantee stock to live.

Substitution.-Should the supply of a variety be exhausted (which will occasionally occur in all nurseries), we substitute in its stead a sort of the same season of ripening, and similar in other respects, or give the value of another grade of the variety named. When it is desired that we shall not do this, it must be so stated in the order. To simply afflx the words "No substitution" is all that is necessary.

Canadian customers may deduct ten per cent. from these catalogue prices on account of duty, which we thus share with them.

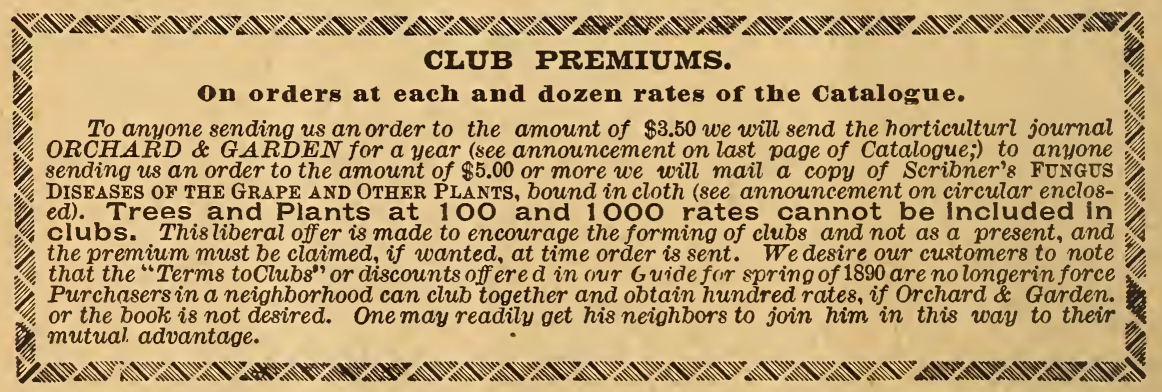

Large:planters and others wanting stock in quantity should write us for special rates.

Should you receive two copies of the Catalogue please hand one to a neighbor interested in Horticulture.

J. T. LOVETT CO., Little Silver, New Jersey. 


\section{THREE GRAND BERRIES,}

Illustrated in colors on next page.

A GRAND OFFER AND A GRAND OPPORTUNITY INDEED, FOR ALL LOVERS OF FRUIT!

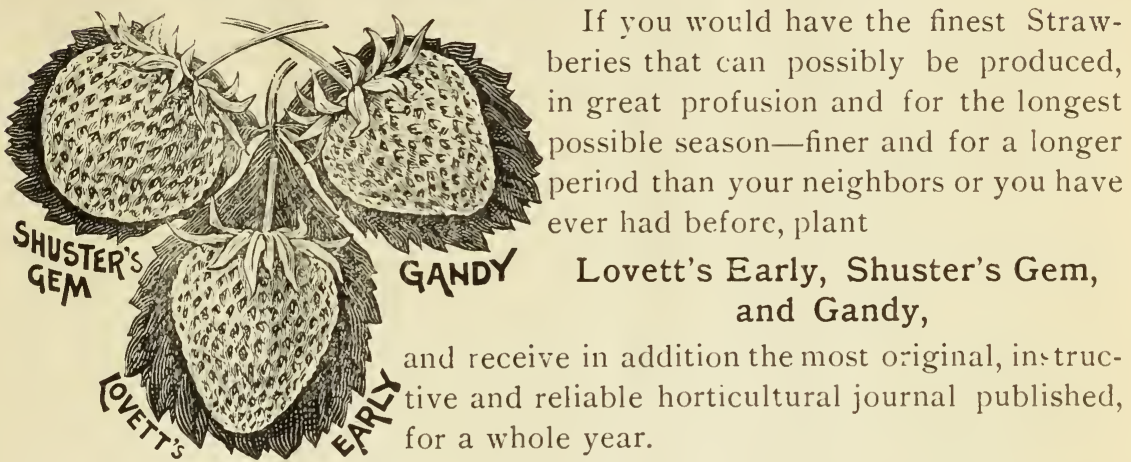

Lovett's Early is not only a very early variety, but large, beautiful, firm and cxcellent; and with such a sturdy plant that it succeeds every where, yielding cnormously. See full description page 5 .

Shuster's Gem unites large size, prolific bearing, delicious quality and wonderful beauty-the finest and most prolific sort, thus far thoroughly tested, ripens in midseason. See page 6.

Gandy is so much later than any other, and is so exceedingly large, fi:m, beautiful and excellent, it can be compared with no other sort, as there is no other that can compare with it. See page 9.

In order that every body may have the finest Strawberries for a longer season than was possible in the past, we have grown a large stock of fine plants of these "three grand berries," and offer them in collections as follows:

A dozen layer or ordinary plants of each for $\$ 1.25$; twenty-five of each for $\$ 2.00$; fifty of each for $\$ 3.50$; I00 of each for $\$ 6.00$.

Any of the above collections will be sent by mail, if desired at prices affixed.

'To gratify those who wish to obtain fruit the first season, we have carefully grown a few thousand plants of each in small pots ancl will send

A dozen Pot-grown plants of each for \$2.50; twenty-five of each $\$ 4.00$; fifty of each for $\$ 7.00$; one hundred of each for $\$$ I2.00.

These pot-growen plants cannot be sent by mail but must go by cxpress or freight.

I IN ADDITION we will send any one ordering any of the above Collections (except the Collection of a dozen each for \$1.25) Orchard and Garden, the best horticultural journal published, a whole year, frce of charge, if so instructed when the order is sent.

J. T. LOVETT CO., Little Silrer, N. J.

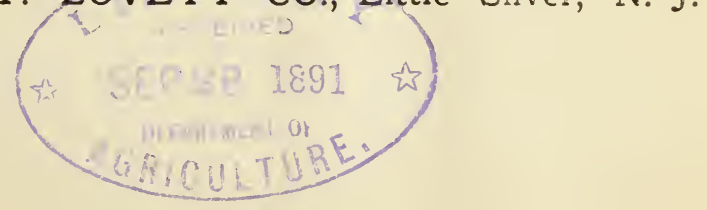


THREE

GRAND RERRIES

Each the best of its season:

Early, Medium, Late
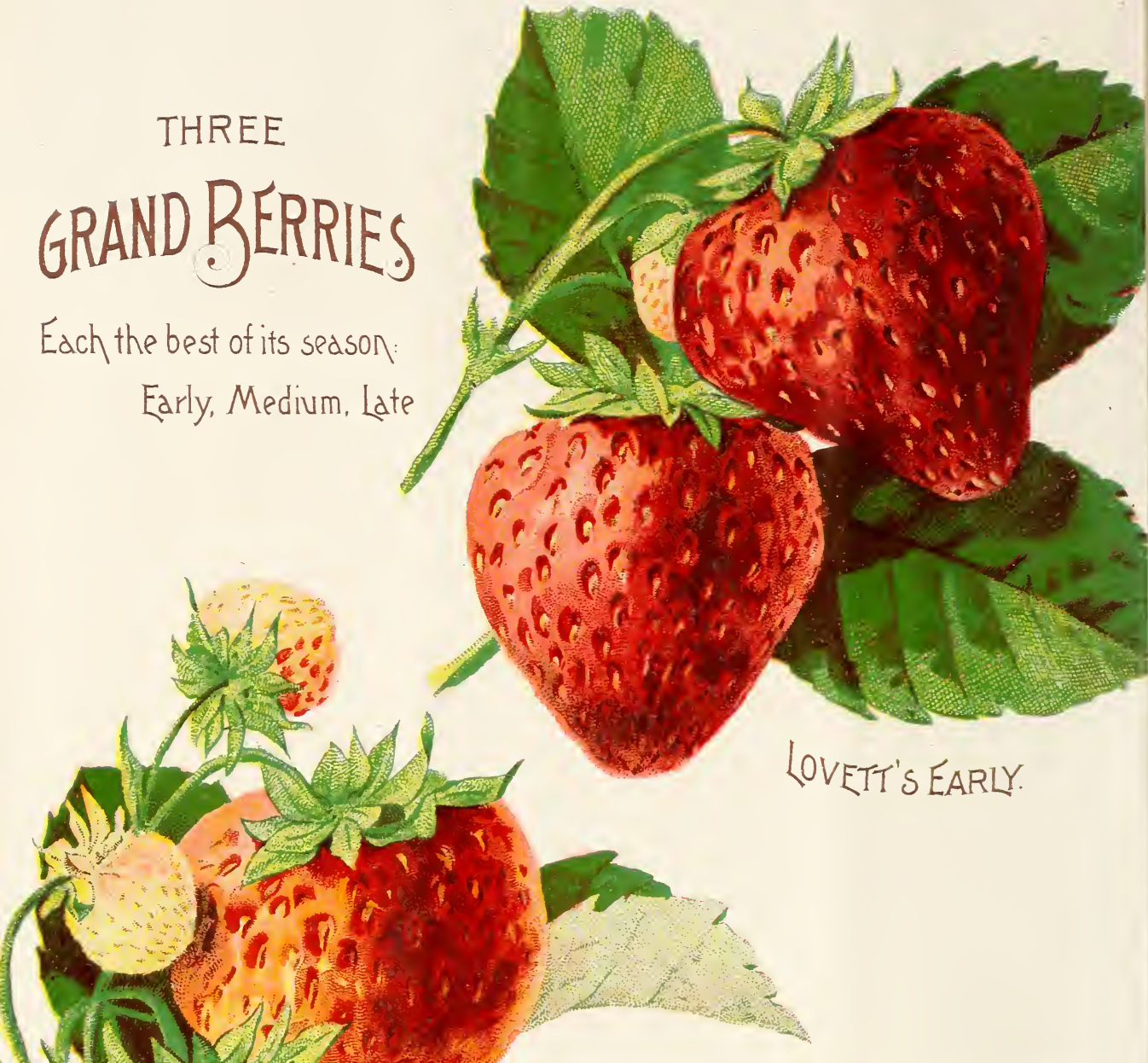

Navis
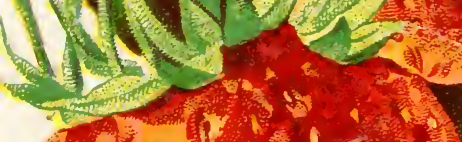

LOVETT'S EARLY.

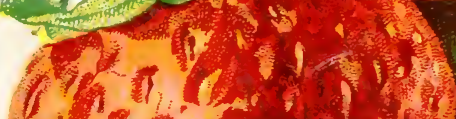

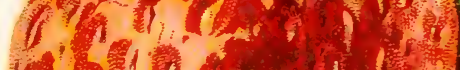
$18(10,11)^{2}$

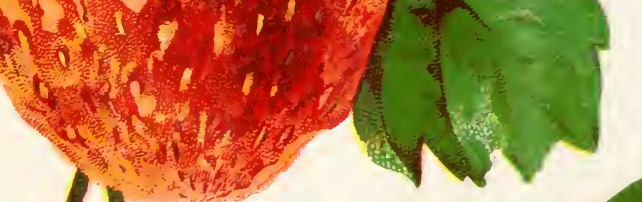

SHUSTER'S GEM.

Introduced \& For Sale by 8 J.T.LONETT CO, =
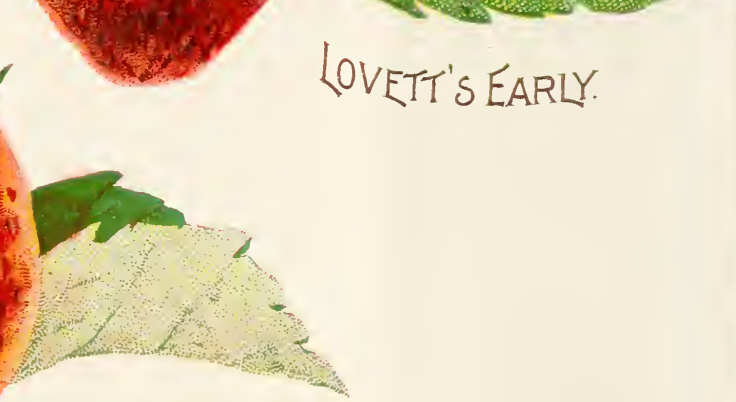


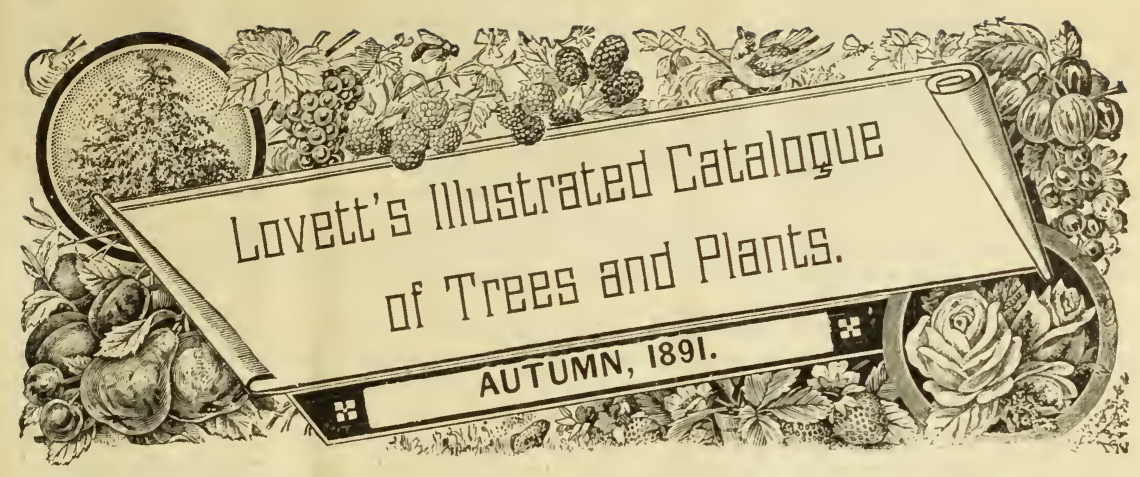

What a year of plenty we are.:having ! Even the croaker-he who complains of the weather and the seasons,-has been sllenced; unless indeed his malady has become so chronic that he must find fault and now complains because there is too much fruit. The Apple crop, the yield of Pears. Peaches, Plums, Grapes and in fact all fruits, with the single exception of Strawberries, has been one almost without a parallel in both its magnitude and perfection. We speak of course for the East only, but from reports received from the West, North and South we are led to hope the grand supply has been universal throughout the land. Not only has the season been exceptionally favorable to the fruit crop hut equally so for Flowers and Ornamental Trees and Plants. As we pass through the long rows of our Nirseries the thought repeatedly presents itself that never before dld we know the Shrubs and Vines, the Hydrangeas, the Yuccas, Pæonies, Phlox, Roses, Day Lilies, Iris, etc., to bloom so brightly or so profusely as in 1891. Nor did we ever see the Shade Trees and Coniferæ clothed in denser mantels of deeper green.

In time of peace prepare for war is a trulsin we should not forget, and whlle enjoying our great abundance, prepare for the future. With very few exceptions, Autumn is the best season for planting Trees and Plants. We then have plenty of time to prepare the soll thoroughly and do the work well. Collectlons to select from are full and we avoid the disastrous droughts that usually prevall in spring.

(1) LOCA'TION. - The IR unson and Monmouth Nurseries are located within thirty miles of New York City, tive miles of Long Hranch and two miles of IBed Bank. To reach them from New York, take the Central Rallroad of New Jersey, (foot of Liberty Street), or the Pennsylvania Railroad (foot of Cortland $t$ or Desbrosses Streets). From Philadelphia, take the Philadelphia and Reading Rallroad (Bound Brook Route), or Pennsylvania Railroad (Broad and Market Streets). In all cases get ticket for Little silver, (good on either road). Or the Nurseries may be approached via the New Jersey Southern Railroad to Red IBank, and by steamers from New York to Red IBa nk.

(2) Shipping Season.-..The regular shipping season in autumn usually begins early in October. During mild winters we can ship at intervals between periods of cold weather throughout the winter. There is no better season for having Nursery stock shipped-especially to points South and Southwest, as planting in those localities needs to be done early. In the manner we pack, no fears should be entertained of the plants being injured en route by freezing, particularly if forwarded b5 express or mail.

(3) How Far do We ship.--We are often asked can we ship plants safely to points named throughout the United States. We can and do ship to all parts of the world with entire safety. Not only do we make many shipments, both by mail and express, to Texas, California and every other State and Territory in the Union, but also to Canada, Europe and even India, Japan, South America and Australia. Our trade in Canada is very large, and is rapidly growing in France, Germany and England.

(4) Express or Freight Charges.--Many write asking the price of such and such goods, delivered at, or the charges of carriage on same, to a certain point. Our correspondence on other matters is so great, and we are all so busy, especially during the shipping season, that this ls something we cannot attempt to give, except in car-load lots. By simply inquiring at the oflice in the place the rate to New York and by estimating the weight of the goods when packed, an approximate amount can be arrived at. We are situated so near New York and the expense from here to that eity is so slight that it is not worth considering. The rate from New York will never exceed the rate from the same place to that city, although it is frequently less. Note our special and superior shipping facllities. The charges are always paid by the purchaser unless by agreement to the contrary. The weight of trees and plants varles with sizes aud varieties, but on an average their weight per 100 when packed will be as follows: Apple, Pear, Plum, Cherry and Peach trees, Arst-class, $100 \mathrm{lbs}$;:Peach 3 to 4 feet,Quinces, etc., $50 \mathrm{lbs.;Grapes,Currants} \mathrm{and} \mathrm{Gooseberries,}$ two years, 30 lbs.; ditto, one year, 20 lbs.; Blackberries and Red Raspberries, 10 lbs.; Black Raspberries, 5 lbs.; Strawberries, $30 \mathrm{lbs}$. per 1000.

(5) Estimates.--Estimates will be cheerfully and promptly furnished to those wanting stock in large quantities. Be careful to name the varieties desired, number of each and grade, and our lowest flgures will be given. 


\section{J. T. Lovett Co.-Items.}

(6) Ordering.-A certain class of people will wait until they are all ready to set plants or trees and then on comes the order. "Fill at once as my ground is ready," forgetting that we may have many orders on hand that must be filled flrst, and that their tardy orders must take their turn. Don"t do this, please don't : While there are many advantages to be gained by ordering early, nothing is to be gainedby orderinglate. As we have been put to much trouble and expense by persons ordering goods to be reserved for them, and failing to remit, thus throwing the stock upon our hands at the close of the season, a total loss, iu the future it will be an invariable rule to accept no order from those unknown to us, unless at least 10 per cent. of the amount accompanies the same.

(7) Lost orders.- Should you not hear from us in a reasonable length of time after sending an order, please write us giving all the particulars-when forwarded, the amount of money sent, and in what form remittance was made-and enclose a duplicate of the order, giving name and address plainly and in full. Once in a great while an order is lost; but it more frequently occurs that the person ordering fails to give the full address. Therefore, no matter how lately or how often you have written, always give name, Post Office. County and State in full.

(8) Idditions and Changes.-- Te will do our utmost to comply with the wishes of patrons to pack additions to an order. or subsequent orders, in one package; or to make reasonable changes in orders, but we cannot promise to do so. During the rush of the shipping season, when sereral hundred orders are received and dispatched in a day, it rould, in some cases, be almost impossible to comply. No change or countermand of an order can be considered as final without our written consent.

(9) Vew Varieties for Testing.-Te are constantly testing new varieties of Fruit from all parts of the country. If you or any of your neighbors have anything promising in the way of new varieties, we shall be pleased to have a few plants of it for testing, which, of course, will not be allowed to go out of our hands under any circumstances without instructions from the owner. In sending put the name of the variety upon it, if it has a name, and the name and address of the sender atways. This is allowed by the Post Uffice in sending Plants by Mail. Please send notice by mail also the same day they are sent. Forward in the early part of the week always, that the plants will not be laid over on the road during Sunday. Then moss and oiled paper are not at hand, use wet chaff or other material that will hold moisture, and wrap tightly in wet rags. Always ship by C. S. or Adams Express (when sending by express) if possible.

(10) A gents. - We desire to impress upon purchasers the great advantage of ordering direct from $u s$, as we employ nn ayents and are only responsible for orders sent direct to us. Thus our relations with our customers are on a proper basis and we endearor to give perfect satisfaction to each one who so orders. Some think because our prices are so lou that our stock cannot be good. This is ouing to the fact that in many cases the cost of traveling agents in soliciting orders and delivering stock is more than double the value of the Trees, Plants, Vines, etc., whilst we, dealing, as we do, direct with the planter, can sell at these low rates the very best stock to be had anywhere.

\section{FALL PLANTING.}

We wish everybody knew the important fact that with the exception of Strawberries, Cap Raspberries, Evergreens, and a few other kinds of plants-- which should be removed direct from the nursery row to

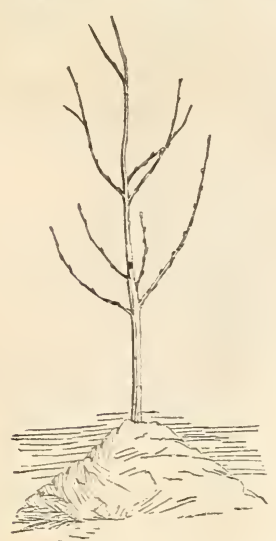
where they are to fruit-the very best way to handle nursery stock is to have it shipped in the autumn and either heeled in on one's own grounds for early spring planting, or planted at once in the orchard, fleld or garden. Our springs are treacherous. If the procuring of trees and plants to be planted, is deferred until spring the preparing of the soil where they are to be set is liable to be also: and by the time the stock can be obtained and planted it is so late that growth has started and dry, hot weather almost always follows before it has had a chance to get a hold on the soil and established, causing a good share of the very best plants and trees to die. Not only this but those that live become more or lessstunted and make only a feeble gromth compared with those planted in early spring or autumn, for these hare the advantage of the early and heary spring rains to settle and firm the soil about their roots and the first warm days to make growth which will not be cbecked. In the antumn the planter bas more time to prepare his ground carefully and thoroughly than in

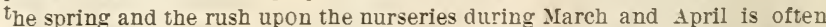
such as to render it practically impossible to make shipments promptly. Then trees are planted in autumn a small mound of earth should be made at the base of each one to prerent swaying, as shown in the accompanying figure, which should be reduced to the level in the spring as soon as the ground has become "settled." A similar but smaller mound of either soil or manure should be made at each Blackberry, Raspberry, \&c., after planting, to prevent repeated and serere freezing at the roots, and removed as recommended for trees. The best and most thrifty fruit growers throughout the.country-the progressive,forehanded ones-practice getting in their supply of nursery stock in the fall.

\section{A Rule to find the Number of Plants Required for an Acre.}

Multiply the length by the breadth, in feet, and see how many time the number is contained in 43,560 , the number of square feet in an acre. For instance, plants set $2 \times 3$ feet, each plant would require six square feet-43,560 divided by 6 gives $\%, 260$-the number of plants required for an acre at the abore distances. 


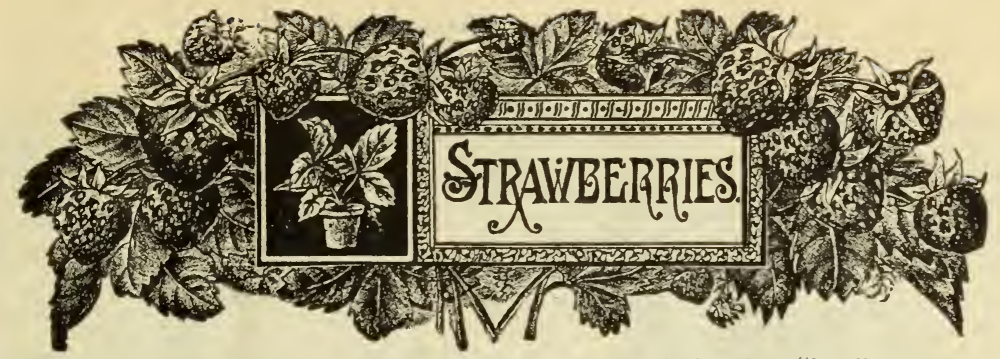

Cult u re.-On arrival of plants, unpack them at once, loosen the bunches, "heel" them in the grousd as described at front of Guide, or dip their roots in a "muddle," made by mixing earth in water until of the consistency of cream, and lay away in a cool, damp cellar, where they can neither dry nor freeze, until they san be planted in suitable weather. Do not leave in package and pour water over them, as this will surely cause the plants to heat and spoil. If by chance tbe stock should arrive in a frozen state. bury the package or place it in a cool place until the frost has become entirely abstracted by slow degrees. These remarks apply also to other Plants aud Trees, as well as Strawberries. The Strawberry delights in a moist soll, but will succeed almost anywhere, if well manured and mulched. Avold planting near trees, as it resents shade. To grow large ierries and plenty of them, fertilizers must be used freely. Unleached wood ashes is a speciflc fertilizer for the Strawberry; ground bone is also excellent. In planting take but few plants from the trench or package at a time, and expose as little as possible to wind or sun. Never plant on a windy day, and never plant in freezing weather. Do not plant deep, but press the earth very frmly about the roots. Should the weather be warm, shade valuable plants for a few days with a handful of coarse litter over each plant, or with berry baskets or boxes (old rejected ones are as good as any.) In Autumn planting it is a good plan to defer it until just before freezing weather, and cover each plant with earth, to be removed at the approach of Spring. By this method the plants start early, make a strong growth, and scarcely one will fall.

For hill culture, plant in beds four feet wide, with alleys two feet between them. Plant in each bed three rows of plants flfteen inches apart, and the plants the same distance apart in the rows. For the mat. ted-row system, plant in rows three feet apart, and the plants a foot apart in the rows; requiring 14,5:0 plants per acre. For the best results, mulching with some light material is indispensable, which should bo applied just as soon as the ground has become slightly frozen, and partially or entirely removed when the ground has become "settled" in Spring. It is well for all to plant at least three varieties-early, medium and late-to expend the season to its full limits.

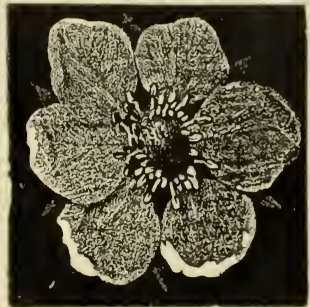

The blossoms of all verieties are bi-sexual or per fect, except those marked with the letter $\mathbf{P}$, which are destitute of stamens and are termed pistillate or imperfect, as shown by the following flgures. Pistillate varieties must have a row of a perfect-1lowered sort, planted every nine or twelve feet apart among them, or, better yet, every third or fourth plant in the row, to pollenize their blossoms. When properly fer tilized the pistillate varieties are the most proliflc and there is no reason for any prejudice against them

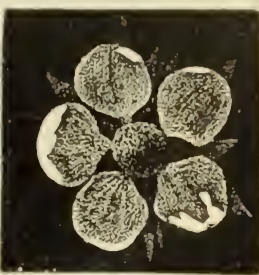
Success depends in a great measure on getting fine, PistLLLATE, or Imperfect BI-SEXUAL, or Pertect. healthy plants, strictly pure and true to name. This we know our plants to be.

In shipping plants, we send out none but young plants, as shown at Fig. 454, grown under the so-called "pedigree system." We never send out old plants. When grown on deep, black soll the roots of young plants are of a dark color, but soft, succulent and nearly uniform in size and appearance, as shown by the figure fust referred to. With old plants, the lower roots are black, dead and wiry, with generally a few young roots just below where the leaves are foined to the crown, as shown in Fig. 456. We clean all plants of dead leaves and tie in bunches (Fig. 455) before packing. Strawberries are perhaps the most difflcult of all nursery stock to ship long distances in good condition, and to overcome the danger of dauage in shipment we pack large lots in cases designed and manufactured expressly for the purpose.
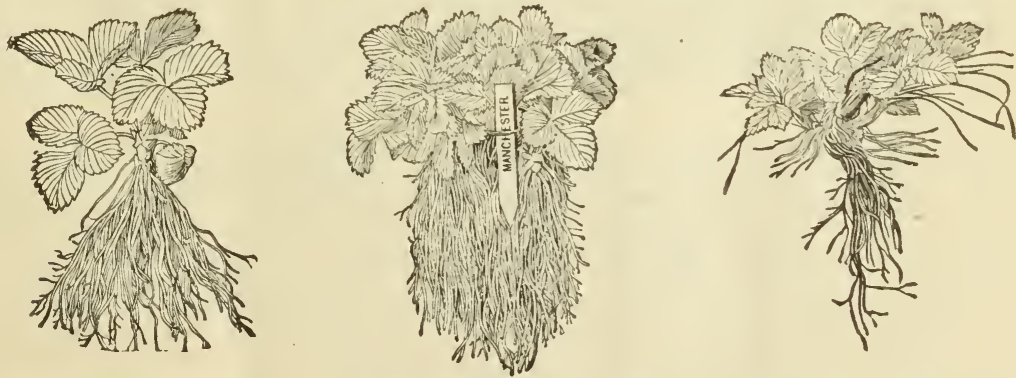

Young Plant. Fig. 454.

Plants Bcxcher. Fig. 455.

(3)

Old Plants. Fig. 456. 


\section{J. T. Lovett Co.-Strawberries.}

\section{NEW VARIETIES.}

By mail post paid at dozen and hundred rates.

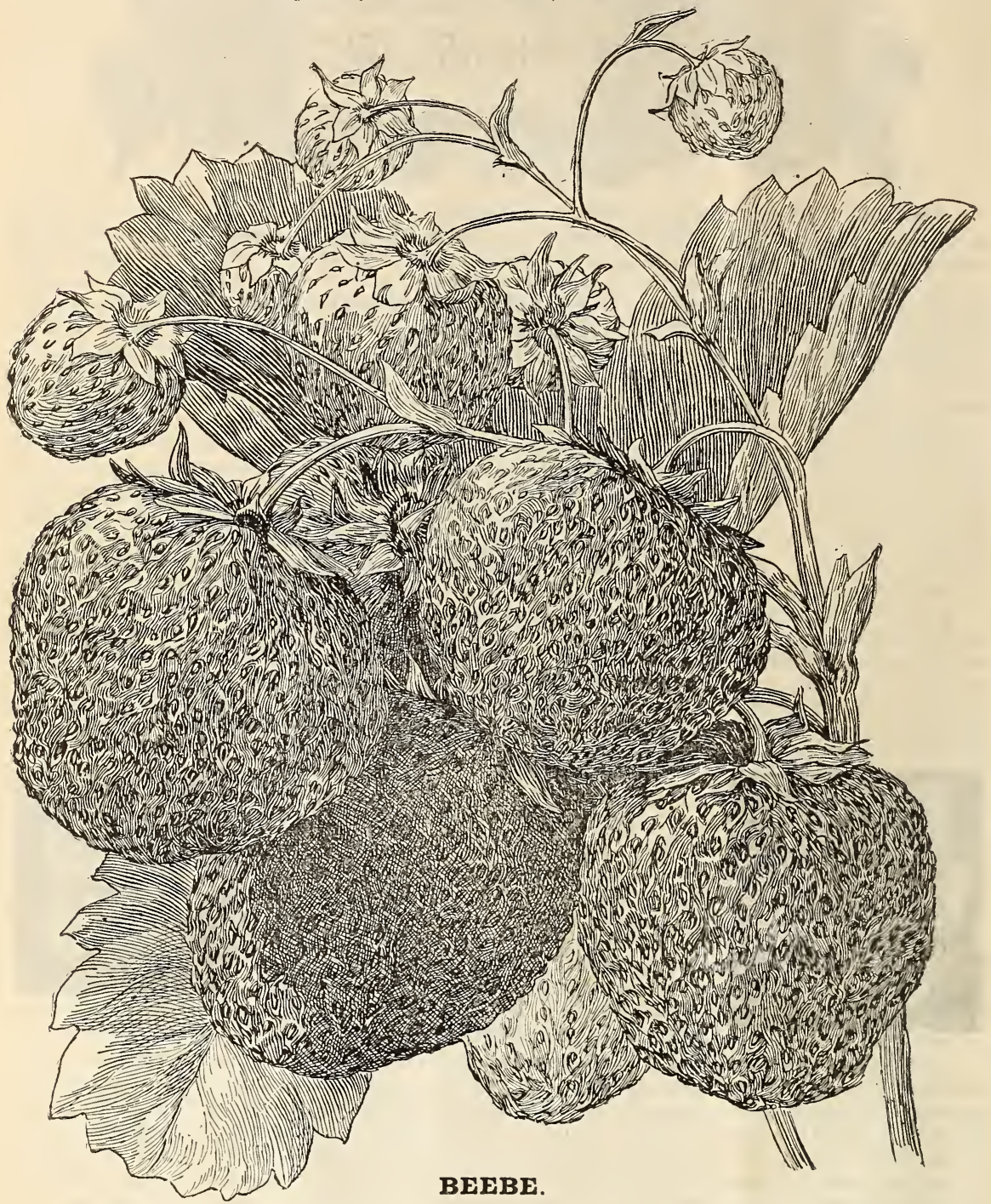

"The Beebe Strawberry originated as a chance seedling on my grounds in the year 1885. The blossom is large and staminate-keeps in bloom until berries are ripe. The berry, when ripe, is light red, large size, mild flavor, a good keeper andwonderfully productive. In 1891 ripe berries were picked as late as A ug. 9th, the largest measuring flve inches in circumference. Its uniform size, mild flavor and productiveness, make it very desirable as a home berry. In shipping quality it ranks better than the Sharpless."-E. P. BEEBE.

For large size, prolific yield, and rich, mellow flavor this is indeed a grand variety. The berries are globular in form and of a deep scarlet color, ripening in midseason. The plant is exceptionally free from rust, having clean, bright foliage, like its supposed parent, Miner's Proliflc, and possesses a perfect blossom. This very promising new strawberry originated with Mr. E. P. Beebe, of Union Co., N. J., a careful and conservative horticulturist and nurseryman, with an experience extending over a quarter of a century, who prizes it so highly that he deems it worthy of bearing his name. We have watched it closely for some time and were permitted to plant and test it on our own grounas before purchasing, which we have carefully done, with the result that we quickly bought the whole stock and control of it, paying a good round price for the same. We now offer it this season for the first time, and feel assured that it is destined to meet with wide popularity among those who aim to grow extra large fine fruit.

Price, Doz.,\$2.00; $100, \$ 10.00$, Pot-gruwn, Doz..\$2.50; $100, \$ 12.00$. 


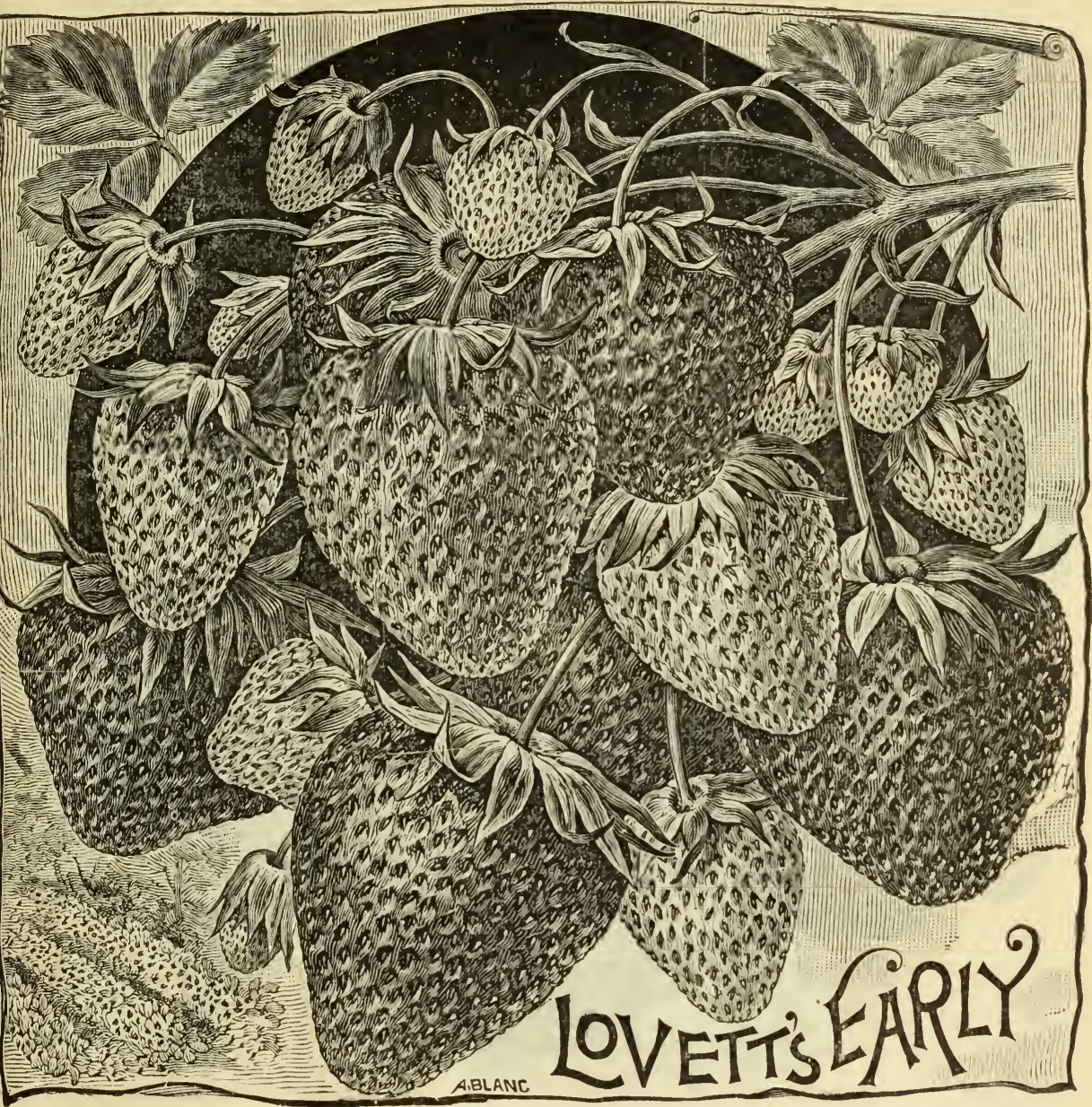

"Lovett's Early is, without doubt, the most promising of the early varieties. The plants are rank and vigorous growers, the fruit ripens earl $\mathrm{H}$, is large and uniform in xize, firm, of a high rich color, splenaid in flavor. It is perfect flowering, and very desirable as an early viriety, und a prolific bearer."-AMERICAN AGRICULTURIST.

"Lovett's Early is a first-class strawberry and no mistake. Try it."-FARM JourNaL.

A wise son maketh a glad father, and a fruit proving under general trial a valuable fruit maketh a glad disseminator. Therefore the whole world seems very bright and beautiful to us-and the joy we experience goes far to mitigate the trials and tribulations attending the management of a nursery. Lovett's Early strawberry-which we have fruited the past year on a more extended scale thall any other-has nct cnly borne out its previous good record of excelling all others as an all round general purpose berry, but we are receiving most favorable reports upon it from the Experiment Stations of almost every state in the Union and not a single unfavorable one among them all.

Lovett's Early gave us ripe berries on May 22nd, the earliest date we have ever gathered ripe strawlerries. Beginning thus to ripen early it continues to near the close of the season, and owing to its wonderful vigor of plant it maintains a good size and good form to the end. It does not give so great a yield at any single picking as soma varieties that go quickly, but during the whole season, frcm flrst to last, we have yet to see a strawberry produce so much fruit upon a given space and under neglect. The berries are not of the colossal size of the Sharpless, although seldom, if ever, 111 -shaped. They are of the brightest crimson, excel in firmness any variety except Wilson, which the equal. retain their bright colcr and "stand up" longer than any other sort, and are of superb quality. In bilef it is an improvement upon both the Crescent and Wilson, from which two varieties it has undoubtedly descended, being much larycrand more prolific than either, and equalling or excelling thwe heroes in ciery good proxer ty. The lant is perfection itself in habit and glowth and the blossom is perfect. (See Colored Plate.)

Price, doz., 75e; $100, \$ 4.00 ; 1000, \$ 25.00$. Pot-grown, doz, $\$ 1.25 ; 100, \$ 6.00$. 


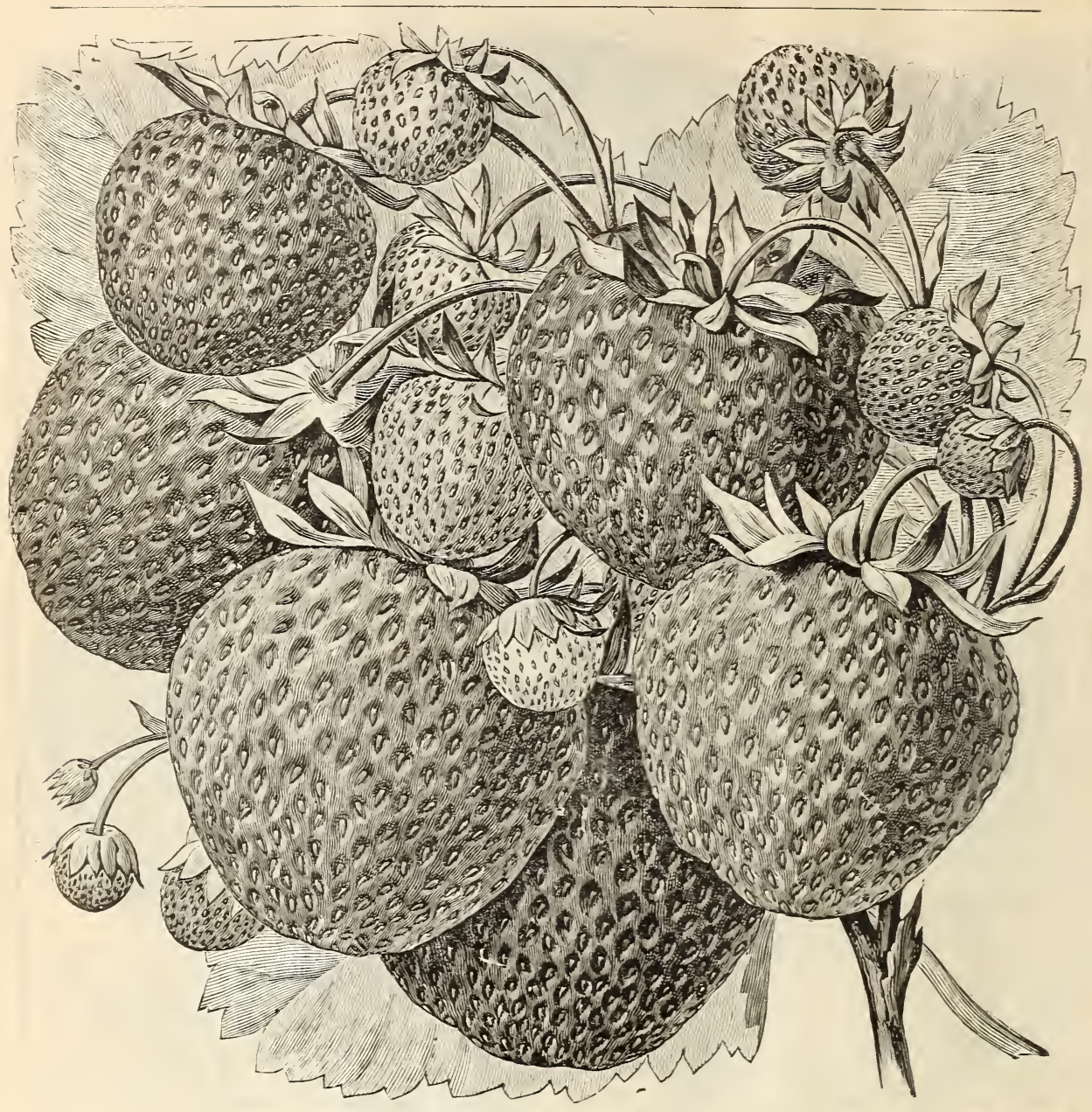

\section{SHUSTER'S GEM (P).}

"All things considered, we must regard the Shuster as a remarkable berry--as good as Bubarh in all respects and better in some as, e. g. color, shape, productiveness, long bearing period and retention of size during the entire season."--RTRAL NEW YORKER.

A cross between Crescent and Sharpless it inherits to a great degree the characteristics of its parents as will be seen and recognized from our description of it. The plant is unusually strong and vigorous, with bright, healthy foliage and a pistillate blossom. The fruit is large to very large, of globular shape, exceedingly regular and uniform in both size and shape, maintaining a good size to the end of the season, beautiful bright scarlet in color and of excellent quality. It is only moderately firm, however, and hence is not especiallp adapted for distant shipment but for a near-by market or for the home garden it is unexcelled. It ripens from early to midseason, continuing in bearing until late. It does not need petting of any sort and seems to adapt itself to almost any soil and treatment. It will grow well just where it is planted, if any variety will. Its great points of merit may be summed up and noted briefly thus: a strong. robust plant, healthy, vigorous and proliflc; fruit of large size, uniform shape and great beauty; quality excellent. It has the size and vigor of the sharpless and the productiveness of the Crescent.

Shuster's Gem has fruited with us since 1886 and we have carefully noted its behavior under ordinary fleld culture ever since. In view of its splendid behavior here and elsewhere, we purchased from the originator the entire stock and control of it and offered it for the flrst time in 1890. The past season under somewhat adverse circumstances it has held its own as a beautiful, prolifle berry of large size. Te do not know of a variety of stramberry that has a brighter flame-colored scarlet color. For the home garden it should become a general favorite. (See Colored Plate.)

Price, dozen, 50c; $100, \$ 3.00 ; 1000, \$ 20.00$.

- Pot-grown, dozen, $\$ 1.00 ; 100$, $\$ 5.00$. 
Lowa Beauty (Childs).-For beauty of form

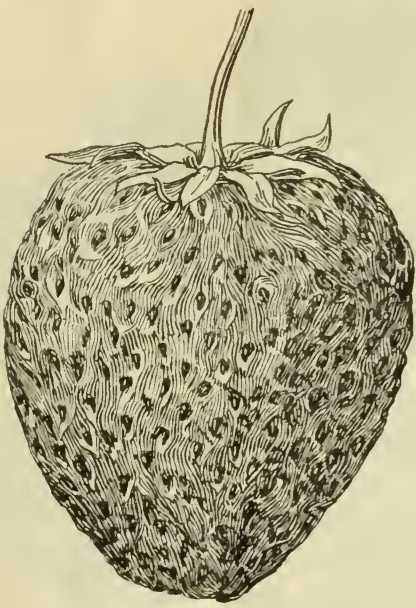

and color we do not think its equal can be found anywhere-certainly we have not seen it. Beauty. however, is not its only merit, for it is of large size, exceedingly firm and of the highest quality. The berries are as regular in form as Pippin apples, of the shape shown in the flgure and exceptionally uniform in size. Color brilliant crimson and so glossy as to have the appearance of having been varnished, with golden seeds laid upon the surface. Plant of very vigorous though not rampant growth with a perfect blossom and yielding abundantly. Te have fruited it two seasons and can give it our unqualifled commendation to those seeking the choicest iruit. Like all berries of this class it requires thorough culture. Ripens in midseason. Doz., \$2.60; 100, $\$ 10.00$.

Alabama. - A recently introduced berry that is receiving much praise at the south. The plant is a stout rampant grower and, in many cases, immensely productive. The berries are large, uniform and regular, bright shining red, very handsome and firm. Early. Doz., 50c; 100, $\$ 1.50 ; 1000, \$ 10.00$.

CRA WVORD. - A superb berry when well grown on rich, heavy soil. The plant is then a good grower and fairly productive. The fruit is large, of uniform, regular shape, bright glossy crimson, solid, and of excellent quality. It behaved remarkably well with us the past season and is well worth growing when one has the proper soll for its ueeds. Midseason. Doz., 35e; $100, \$ 100 ; 1000, \$ 5.00$.

Edgar Queen $(P)$, - From Illinois. A flne strong growing variety somewhat similar in general character to Sharpless, but much more productive. The berries are large, crimson, of good quality but only moderately flrm. For a near market this may prove a decidedly profitable sort, and we regard it as very desirable. Midseason. Doz., 35e; 100, 31.00; $1000, \$ 5.00$.

Enhance. - A cross between Sharpless and Windsor Chief, originated at Ada, Ohio. Plant very vigorous, a strong grower, and productive. Fruit large, rather irregular, dark crimson color, and firm: quality good, sligbtly acid. It gives indications of being a very profitable market berry for shipment. Medium to late. Doz., $75 \mathrm{c} ; 100, \$ 3.50$.
Farnsworth.-It is chiefly as a family herry for home use that this variety possesses merit, for aside from its superior quality, it has no very prominent characteristics to recommend it. Although the plant is a fairly good grower it requires hill culture on rich soil to render it productive. Given these conditions the berries are of good size and in fair quantity; color pale scarlet, moderately firm. regular in shape. It is decidedly a valuable sort for the home garden by reason of its really flne quality, and for such it may be well recommended. Early. Doz., \$i5c; $100, \$ 3.50 ; 1000, \$ 25.00$.

Great Pacific (P).--From Illinois. A strong vigorous grower, making runners freelv, and very productive; the berries however are not great in size but they are firm and of a handsome crimson color of fair quality but acid. Another season's fruiting may show it in a more favorable light. Early. Doz., $50 \mathrm{c} ; 100, \$ 2.50 ; 1000, \$ 5.00$.

JUCUNDA MIPROVED.- One of the fla-

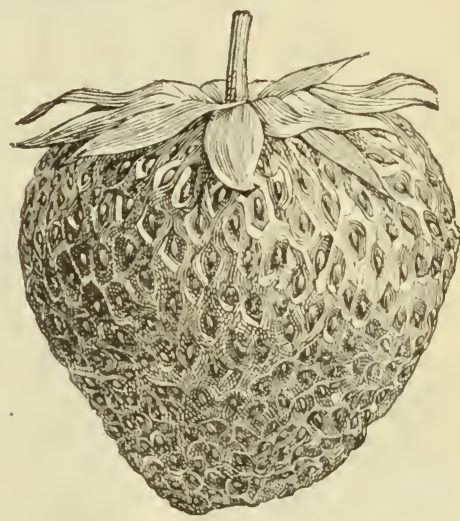

est and most attractive of strawberites, excellent for the home garden aud for markets where large, fancy fruit is in demand. It is really all improvement upon the old Jucunda, the berries closely reseinbling that old favorite and possessing all its good qualities, but the plant is as strong, vigorous and free from disease as the Wilson. It is, indeed, a grand variety, and especially valuable for its large, handsome fruit. Medium to late. Doz., $50 \mathrm{c} ; 100, \$ 2.50 ; 1000, \$ 15.00$.

Middlefield (P), - A Connecticut seedling of much merit. The berry is large and beautiful, rather conical, regular and uniform, dark glossy erimson. of good quality. Plant vigorous and productive. We regard it as a very promising variety. Midseason. Doz.. $\$ 1.00 ; 100, \$ 5.00 ; 1000, \$ 40.00$.

standard.-Originated in Massachusetts and introduced last spring. This has a good growiug plant with healthy foliage, and is said to produce abundantly. The berries are large, bright erimson, fl'm and of flne quality; the flavor is brisk aud sprightly making it a valuable sort for the family garden. Midseason to late. Doz., $5 \mathrm{c} ; 100, \$ 350$; $1000, \$ 25.00$.

stevens.-Claimed to be an excellent shipping berry, and hence valuable for market. The plant shows no disposition to rust and is a good clean, vigorous grower. Fuuit of good size, bright color, very flrm and an attractive berry. Early. Doz., 50c; 100 , (i) 


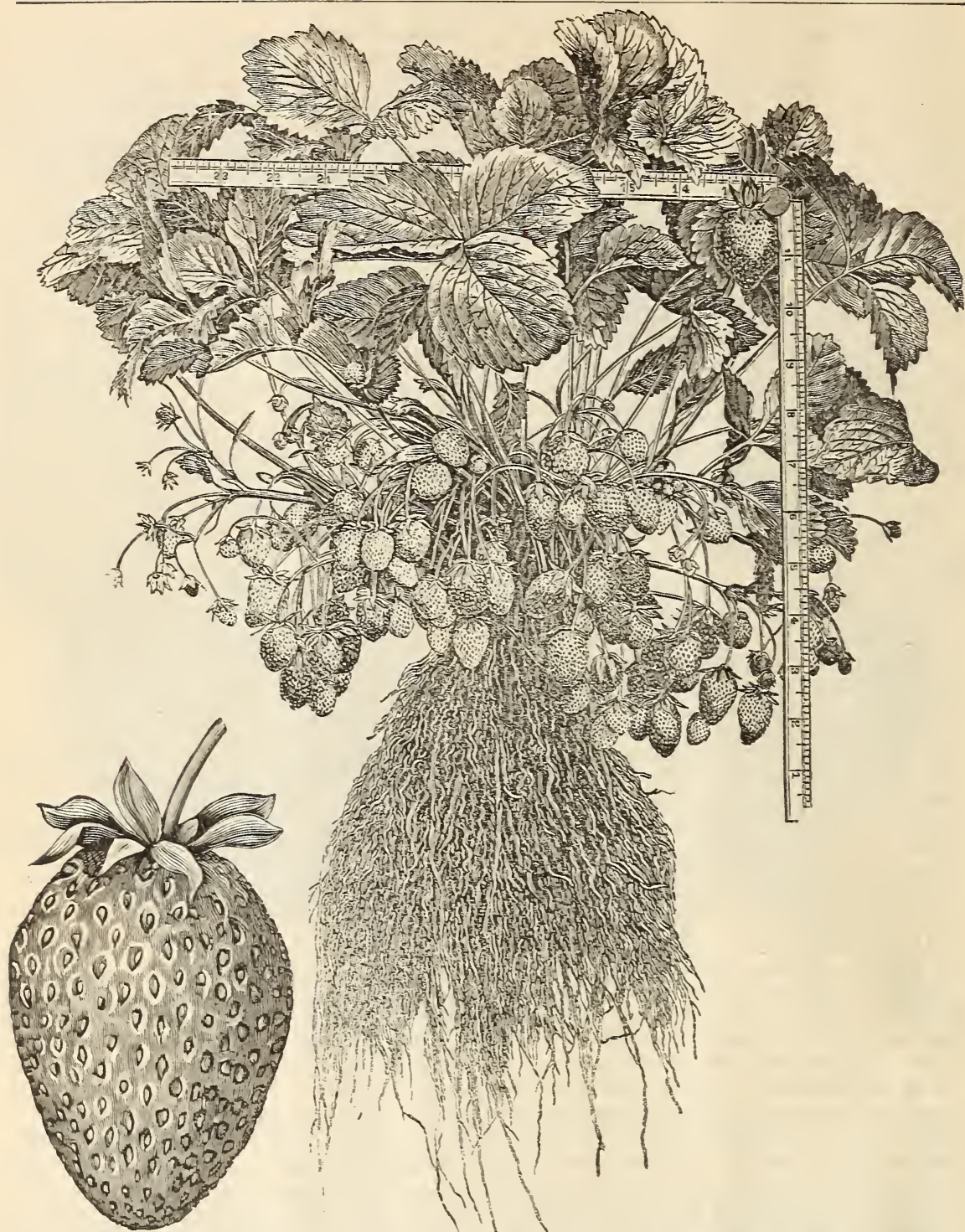

PA K KEK EA RLE. - This will take a high rank not only for its yield and beauty but on account of its adaptability to light soils, and its enduring foliage in hot dry weather: qualities that are rare now among strawberries. The plant is a robust grower, with perfect flower, and is exceedingly productire. The berries are large, conical with short neck. regular and uniform, of a glossr, bright crimson color, flesh firm, reddish and in quality rers good. For vigor of plant, rield and quality combined it is hardly surpassed by any other sort and we rejoice in the prospect that it may prore worthy of the honored name it bears. Midseason. Doz., isc;100, $\$ 3.00 ; 1000, \$ 20.00$.

BEDER WOOD (Racster). - Unfortunately erer, and not likely to stand rery far distant shipthis has been giren two names but Beder Wood is ments in safety. Early. Doz., 50c: 100, $\$ 2.50$.

undoubtedls the correct one since it originated with Waldron $(\mathbf{P})$. $-\mathrm{A}$ strawberry of much ralue. It the gentleman of that name at Noline, Ill., in 1Ss1, has a flne stout plant of robust growth and the berries and who gare his full name to the rariets. It is a are large to rerv large and produced in profusion, of variety worth come an exceedingly raluable early sort. The plant ity rery good. Its undoubted merit will soon make it is a satisfactory grower and an enormous bearer. better known. It sustains the claims made for it Berries large, of roundish, regular form, pale scarlet, much better than most new sorts. Midseason. Doz., and of excellent quality: only moderately flrm, how- 35c: 100, $\$ 1.00: 1000, \leqslant 6.00$. 


\section{GENERAL LIST.}

(The illustrations are one-quarter natural size).

If to be sent by mail add 15 cents per 100; at 1000 rates by express only.

Bidwell.-Early, handsome and good. For all who have heavy soll, one of the best as an early berry. Large, conical, bright crimson, glossy, excellent in quality, only moderately firm. Plant a good grower and, under good culture, productive. Its only fault lies in its blossoms blasting instead of setting fruit-this defect manlfesting itself especially on thin soil and in dry unfavorable seasons to a very decided degree. Doz. 25c; 100, 50c; 1000, $\$ 3.00$.

ВUBA CH $(N o .5)$ P. - A wonderful berry in

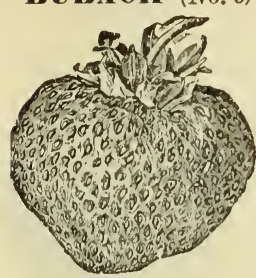

vigor of plant and yield of fruit even under careless culture. It still maintains its reputation for large size and great yield. The fruit is, in many instances, very large but not of first rate quality. It is exceedingly productive and very valuable for a near-by market. Its greatest defect lies in the lack of firmness of its fruit. Midseason. Doz., 25c; 100,50c; 1000. \$2.50.

Capt. Jack (Burt).-An old popular variety, especially at the Wèst, and remarkable for its productiveness and firmness of fruit. The berries are of only medium size, uniform in shape, pale scarlet color, fair quality and exceedingly firm. Plant vigorous, healthy and productive. Plants must be kept from matting by cutting the runners to have it do well. Midseason. Doz., 25c; 100, 50c; 1000, $\$ 2.50$.

CHA S. DO W N I NG.-A well-known and pop-

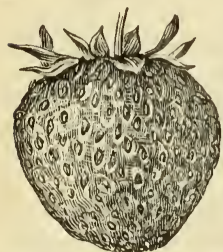

ular family berry of flne flavor. great productiveness and general adaptability to all soils and locations. Of late years its follage has rusted badly which has impaired its value. A peculiarity of the variety lies in the fact that a bed of it is usually more fruitful the second year of bearing than the flrst-and unlike other sorts it will remain fruitful and flne without renewing for several years. Midseason. Doz., 25c; 100, 50c; 1000, $\$ 2.50$.

CRESCEN'T (P).--Very few varieties are so immensely productive as is this and none succeed better under such general neglect. The plant is most vigorous, and for best results should not be allowed to mat closely. The berries are of medium size, rather poor quality and a little soft tor shipment. Bright scarlet color and quite attractive: a profitable sort for market on account of its great productiveness and easy culture Early. Doz., 25c; $100,50 \mathrm{c} ; 1000, \$ 2.25$.

Cloud (P). - A southern market variety much valued for northern shipment. The berries are of good size, handsome and firm; the plant is a rapid, vigorous grower but, with us. only fairiy productive. It does well on light soll. Early to midseason. Doz., $25 \mathrm{c} ; 100,50 \mathrm{c} ; 1000, \$ 2.50$.

Eureka $(\mathbf{P})$. - A very productive variety of the Bubach class of berries, but of better form and of better quality. The plant is healthy and vigorous. Berries large, handsome, moderately firm and of good quality. For market it is a profitable variety. Midseason. Doz., 35c; 100, $\$ 1.00 ; 10 \mathrm{C} 0, \$ 4.00$.
Felton.-A remarkably strong growing plant with healthy foliage. It is a seedling of Sharpless and the berries are large, somewhat ridged, of bright crimson color and quite firm in texture; quality good. Midseason. Doz., 25c. 10n, 50c: 1000, $\$ 3.00$.

Florence (Clara).-Requires heavy, cool soil for its best development. The plant is a good grower and fairly productive; the fruit is large and handsome, bright crimson color, regular shape, flrm and of good quality. Its follage will be apt to rust under hot suns bence adapted only to cool locations. Doz., 25 ; $100, \$ 1.00 ; 1000, \$ 5.00$.

FA NDY (First Season). - The best late strawberry yet intaoduced and the leading late variety with fruit growers all over the country. Its great merits have been quickly recognized and there are tew varieties that have so rapidiy become a leading and popular sort. As a choice late sort it is an entire success. In size and firmuess it is all that can be desired, and in vigor of plant and growth.

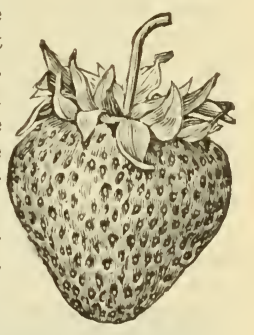

it is eminently satisfactory, but under ordinary culture its yield is not so great as many expect. It is not essential to have heavy soil but to produce best results it is necessary to apply fertilizers liberally. The berries are large, very uniform in size and shape, of bright crimson color, handsome and show y, very firm and of good quality. Late to very late. Doz., $25 \mathrm{c} ; 100, \$ 1.00 ; 1000, \$ 3.00$.

Haverland (P).--Exceedingly productive and the fruit is large and fine. On good rich soll it is one of the best and is proflable by reason of its great productiveness and earliness. It is not sufliciently firm for very far distant shipment but excellent for a near market. Plant healthy and vigorous. Berries large, handsome and good, though not of the best quality, rather long in shape and of a bright glossy crimson. It has been largely planted and has given much satisfaction, having been found very protitable for market. Early. Doz., 25c; 100, 50c; $100, \$ 3.00$.

Hofiman's Seedling.--This is taking the place of the old Neunan's Prollfle at the South for shipment to northern markets and is regarded by many as the most profitable berry for southern growers. The fruit is of good size and exceedingly firm. Plant a strong grower and immensely productive. of but little value at the North, as the fruit is botlı small and of poor quality here. Early. Doz., 25c; $100,50 \mathrm{c} ; 1000, \$ 2.50$.

Jessie.-Except on certain solls and locations this variety gives disappoinment. The plant grows well and is suffleiently robust but it is generally unproductive and the foliage rusts somewhat under a hot sun. The berries are large and beautiful and of good quality. It requires rich soll and good culture and will suit the amateur much better than the market grower. Midseason. Doz., 25c: 100, 50c; 1000, \$2.50. 
Kentucky.- Popular as a late variety on account of its good quality and productiveness, but too soft for long shipments. The plant is a good grower, very productive, and, like the Downing, it succeeds on all soils and under almost all conditions. Other and better late sorts are now, however, taking its place, and it is in much less demand now than some years ago. Fruit is large and of fine flavor. Doz., $25 \mathrm{c} ; 100,50 \mathrm{c} ; 1000, \$ 2.50$.

Lady Husk (P).-A productive variety of good sized berries, firm and of good quality. The plant seems to suffer greatly in dry weather and it will do much better in a heavy cool soil. On account of its firmness and other good qualities it has proved profitable in many localities. Fruit large and of good quality. Early. Doz., 35c; 100, $\$ 1.00 ; 1000, \$ 5.00$.

May King.-One of the best of the early standard sorts. Of the Crescent type of which it is a seedling. Plant vigorous and productive. Berries rather globular, medium in size, of a bright scarlet color, flrm, and of excellent quality. A valuable early market sort. It has clean, healthy foliage of the same enduring character as its parent, but its flower is perfect. Doz., 25c; 100, 50c; 1000, $\$ 2.50$.

Miami (P).-A fine berry of large size and good quality but a variety demanding high culture. The plant is a good grower but not sufficiently productive under ordinary cultivation. It may do betterin othec locations, and in the hands of some growers it has proved very successful. The fruit is so fine that it is well worthy of extra care and culture. Late. Doz., $35 \mathrm{c} ; 100, \$ 1.00 ; 1000, \$ 5.00$.

Irichel's Early (Osceola).-A very earlv variety of the Crescent type with a vigorous and healthy growing plant, but at Monmouth decidedly lacking in prcductiveness and quality. At the South, we are informed, it bears abundantly, and, like Hoffman, is best adapted for southern growing. It comes from Arkansas, where it is highly valued. Doz., 25c; 100, 50c; $1000, \$ 2.50$.

MONIIOUTH.-Ripens early, very closely suc-

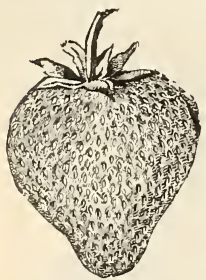
ceeding Crystal City,and a week in advance of May King. The fruit is of large size, bright crimson color, quite regular and uniform, holding its size to the end of the season, exceptionally firm and of superior quality. The plant is small, like Crescent, and although clean and free from disease has of late manifested a feebleness of growth. For an early berry for the home garden or on rich heavy soil where an extra early berry is profitable to raise for market, this variety is unsurpassed. Doz., 25c; $100,50 \mathrm{c} ; 1000, \$ 3.00$.

Parry.-This is similar to Jersey Queen of which

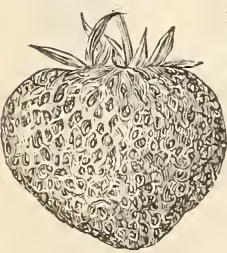

it is a seedling but it is better altogether and, moreover, possesses a perfect flower. The plant is vigorous and productive but it requires heavy, rich soil and good culture. Fruit is uniformly large and beautiful, moderately firm and of good quality. Brings a high price in market by reason of its fine appearance. Doz., 25c; $100,50 \mathrm{c} ; 1000, \$ 2.50$.
Pearl. $-d$ vigorous grower and productive bearer. It does well under ordinary culture, is well adapted to general cultivation, and is a profitable market sort. The berries are large, bright glossy crimson, conical, firm, and of good fiavor. A profitable sort for market growers and valuable for the home garden. One of the very best second early sorts. Doz. $25 \mathrm{c} ; 100,50 \mathrm{c} ; 1000, \$ 2.50$.

Sharpless.-Demands rich, strong soil without which it is likely to prove disappointing in yield. The plant is exceedingly large and vigorous and quite free from rust or blight. Berries large to very large, somewhat irregular in shape, crimson, moderately firm and of good quality. It is a profitable variety for a near market on ac-

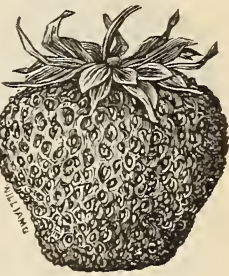
count of its large size, and with good culture will furnish an abundance of fine fruit. Doz., 25c: 100 , $50 \mathrm{c} ; 1000, \$ 2.50$

Stayman's No. $1(P)$.--A variety of western origin and thought to be a seedling of the Crescent. It is much praised by western growers, but has not indicated a very high value here. The plant is an excellent grower with clean foliage, but upon our soil lacks productiveness and size of berry. Doz., 50c; $100, \$ 1.00 ; 1000, \$ 5.00$.

Viola or Monarch of the West.--Though introduced as a new variety this is undoubtedly our old favorite berry. Plant large and thrifty. Berries large, pale red and white tip, delicious flavor. Only moderately firm, but for home use one of the best. Midseason. Doz., 25c; 100, 50c; 1000, $\$ 3.00$.

Walton (P). - We had bright hopes of this berry from the good account of it given by its introducer: but with us it is a total failure, and we cannot recom. mend it. Doz., $35 \mathrm{c} ; 100, \$ 1.00 ; 1000, \$ 5.00$.

Warfield (No. 2) P.-A rival to the Crescent in yield and exceeding it in size, beauty and firmness. In quality it is good, pleasant, subacid. A vigorous grower with bright healthy foliage. It is a valuable market sort and will give good satisfaction. Early. Doz., 25c; 100, 50c; 1000, $\$ 2.50$.

White Novelty. - Of the Alpine or everbearing species, being of strong growth and fruit larger than the old White Alpine. Doz., 35c: $100, \$ 1.00 ; 1000, \$ 5.00$.

Wilson.-The popular old market sort. Still retained for its many good qualities. To obtrin best results it should be grown upon rich, heavy soil and the beds renewed often, when it is large and productive. Its earliness and firmness are the qualities that have made it valuable in the past. As generally grown now it lacks vigor and vitality. Early. Doz., 25c: 100,50 c: $1000, \$ 3.00$.

Yale.-A fine handsome berry but the plant is so susceptible to rust that it will only succeed in cool soils and locations. When well grown the fruit is large, very firm and of a high rich flavor. Well adapted to the amateur who will give it careful culture. Late. Doz., 50c; 100, $\$ 2.50 ; 1000, \$ 15.00$. 


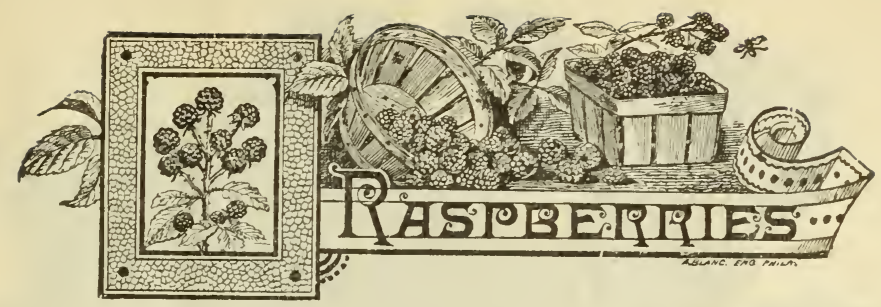

Culture.-Any land that will produce good crops of corn or wheat is suitable for Raspberries; and unlike Strawberries, they are beneftted by partial shade. Prepare the ground thoroughly and manure liberally. Ground bone is a speciflc fertilizer for the Raspberry. Keep the soil loose and free of weeds throughont the season, cutting down the suckers with the hoe or cultivator, and leaving only three or four to a hill or single row for fruiting. Aim to plant an assortment so as to lengthen the season.

The red varieties should be planted for fleld culture, in rows six feet apart, and the plants three feet distant in rows, requiring 2,400 plants per acre; or four feet pach way if to be cultivated in hills, requiring 2,700 plants per acre. It is best to place two plants in each hill, requiring of course double the number. In garden culture plant three feet apart each way and restrict to hills. Soon as planted cut back the canes to within a few inches of the ground, and plants set in Autumn should have the soil mounded up over them to protect them from frequent freezing and thawing. In Spring the earth should be leveled down again. In pruning the bearing canes cut them back one-half their length on an average, but all of the same height from the ground. Foreign varieties and seedlings of them do not succeed much South of New York, as they will not endure hot sunshine. Reference will be made to the origin of these in their descriptions. We do not recommend removing the old canes, as they help support the hearing ones and hold snow in winter.
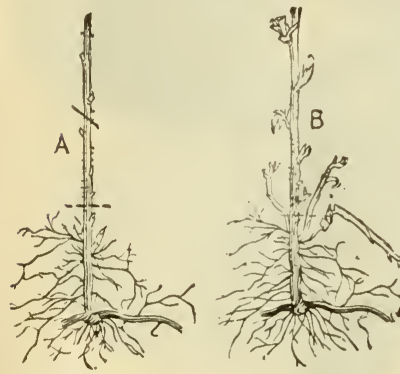

Raspberry Plants. Fig. 350 .
The Cap varieties succeed not only on good soil but many sorts yield large profitable crops on the lightest kind of sandy land. In fleld culture plant in rows seven feet apart and three feet six inches distant in the row; requiring 1,ir5 plants to the acre; or four and a half feet apart each way, requiring 2,150 plants per acre. In garden culture plant four feet apart each way. Fall-set plants should

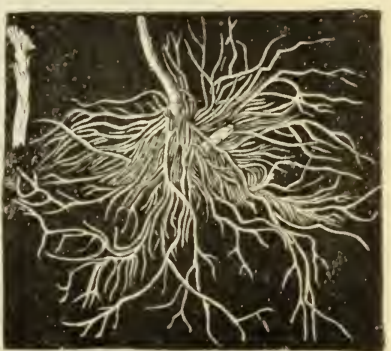

"CaP" Raspberry Plant. Fig. 356. be protected as recommended for other sorts, but we do not advise planting Blackeaps in Autumn, as they are difficult to make live if set at that season. In pruning bearing canes cut at the middle of the bend. As these are propagated from the ends of the canes, being bent down and rooted, they have but little wood upon them as shown by Fig. 356, and are not readily seen when but a small number is ordered. If any should be missed from an order please examine the packing material carefully before concluding that they have been omitted. All of this class are designated in the following list by the word Cap added to the name.

In digging we tie in bunches of convenient size for packing, and grade carefully, putting in none but what have good side roots.

We would like a chance to figure on the lists of those who contemplate ordering largely.

\section{NEW VARIETIES.}

(1f to be sent by mail, add 10 cents per dozen, 40 cents per 100 for postage).

Kansas.-A new blackeap from Kansas of exceeding great promise and undoubted value. Its canes are of vigorous growth with foliage tough, healthy and clean, productive, very hardy. The berries are as large or larger than Gregg, jet black, very handsome, flrm and of flne flavor. Its season may be termed second early, ripening after souhegan but much earlier than Gregg. It should certainly be given extensive trial throughout the country in view of its tine record wherever yet grown, and its size and productiveness indicate great value. It comes into bearing between the early and late sorts. Doz., $\$ 2.50 ; 100, \$ 12.00$.
Older.-This is an excellent blackeap, and several years fruiting enable us to recommend it confldently. We have found it to be a good grower, entirely hardy and its foliage withstands heat and drought better than most varieties, and yields abundantly. The fruit is very large and when perfectly ripe the blackest raspherry we have yet seen and without any bloom. In form the berries are distinct. being unusually flat; they are quite firm and of extra good quality. It ripens in inidseason and is the best blackeap ripening at that time, flling the gap between the early sorts and Gregg admirably. Doz.o 50c: $100, \$ 3.00 ; 1000, \$ 20.00$. 


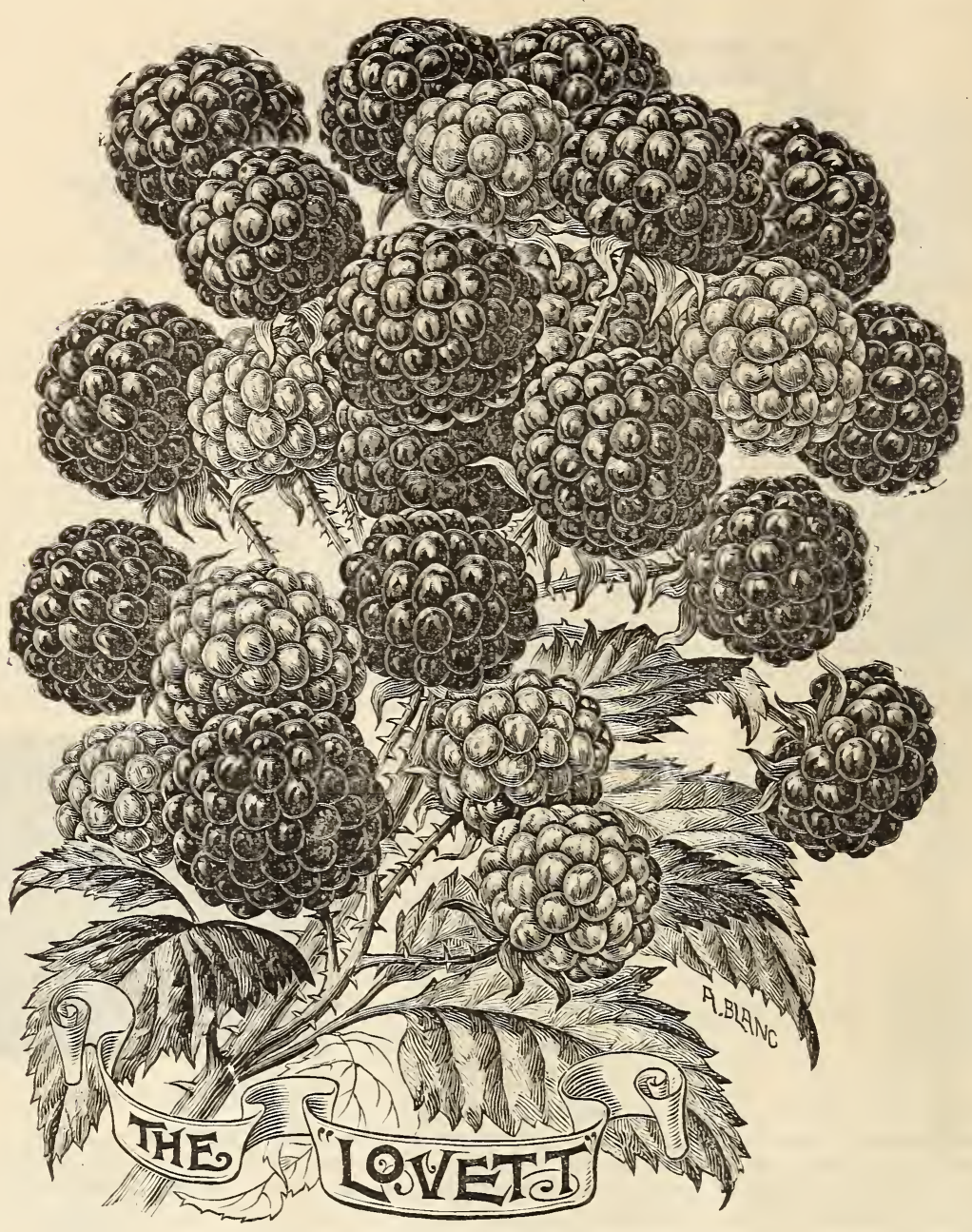

\section{LOVETT or \$1000.00 RASPBERRY.}

"The canes are of vigorous growth, the tallest being over six feet. The berries are borne in short racemes somewhat like those of Gregg, are nearly as large, black, glossy with some bloom around the base of the drupelets. They are as firm as it is desirable a blackcap should be, and never arop from the receptacle. There was no marked difference in earliness between the Palmer, Progress and Lovett. Judged from the first season of fruiting, it is an improvement, all thiugs considered, over any variety we have tried."-RURAL NEW YORKER, in "Notes from the Rural Grounds."

The Lovett Raspberry, which could with propriety have been named Lovett's Thornless (being practically destitute of thorns) has, the past season, fully sustained, in a fruiting fleld of six acres, all that has been claimed for it; and taken all in all has proved itself to be by far the best black raspberry that has as yet been put upon the market. Unlike the Gregg, which it nearly equals in size of berries, it is of ironclad hardiness; and is the strongest in growth of cane of any, unless possibly the Ohio excepted. In enormous yield it is without an equal. Add to these properties superior quality, jet black color, flrmness and long life after gathered, adhering to the bush when ripe, and above all, its earliness (ripening with Souhegan and the other very early sorts) and we have in it, what has so long been wanted and a most valuable fruit. So far from regretting our outlay of $\$ 1,000.00$ for the control of this berry, we now congratulate ourselves on our good fortune in securing it for that sum. It is entirely distinct from all other sorts. We have now fruited the variety for three seasons and know positiveiy that it possesses the merits claimed for it.

Price, dozen, \$2.00; 100, \$10.00; 1000, \$75.00.

66 Transplanted plants, dozen, $\$ 2.50 ; 100, \$ 12.00$. 
THOMPSON'S EARLY PROLIFIC.-Remarkable for its early season of ripening. The

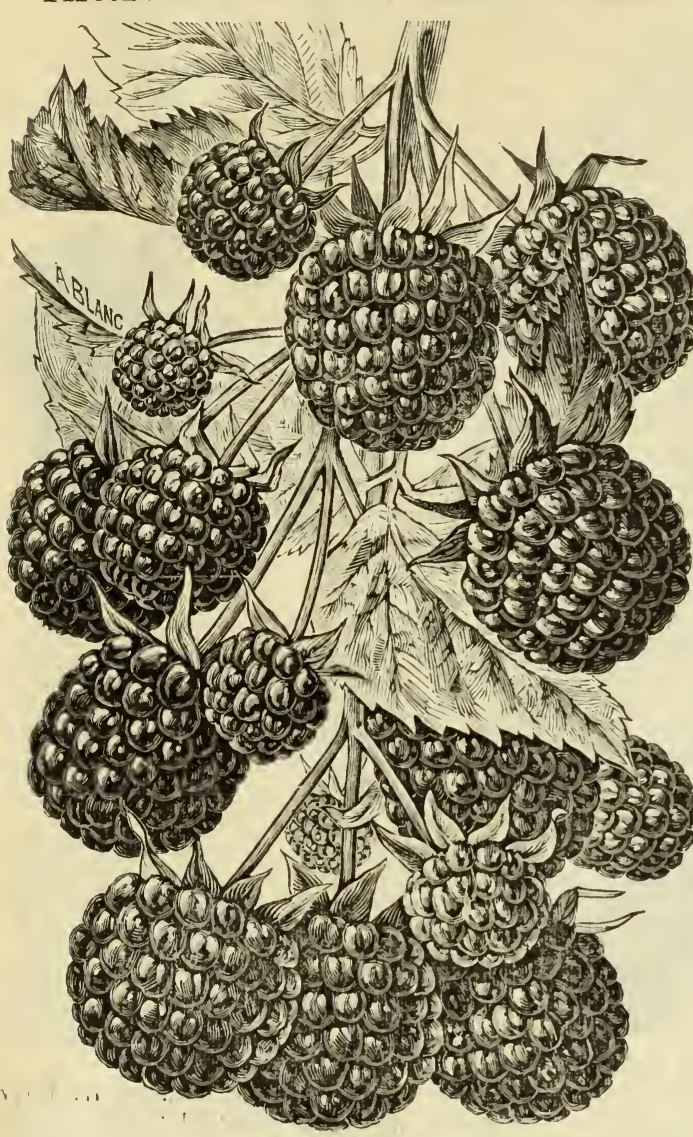

plant is an excellent grower, the canes erect and stout: quite hardy and said by the originator and introducer to have endured $22^{\circ}$ below zero without injury. Foliage of a dark green color, tough and healthy, and endures well heat and drought; here it is quite free from rust and mildew. The berries are medium to large in size, of a strikingly bright, fresh, crimson color, very attractive, which, with its extreme earliness, should cause it to beeome a profitable market sort. It is exceedingly productive with us and has received nospecial care or cultivation. In brief, it is similar to Brandywine, of about the same size, with the same bright, fresh color and ripens from a week to ten days earlier. It has already shown much value by its early season of ripening, great productiveness and vigor of plant. It is admirably adapted for planting at the South, where it succeeds splendidly, being on of the very few, and the best, that can be satisfactorily grown there. It is the earliest red raspberry we have seen, coming into bearing just as the strawberry season is over, and ripened at Monmouth the first among all raspberries by fully a week. We have also seen it in Ohio equally flne, the canes of stronger growth and yielding a heavy crop of fruit. Reports concerning its behavior are exceedingly satisfactory and conflrm our opinion of its value as a proftable sort for both market and family use. The scarcity of good varieties of red raspberries renders this early sort especially valuable and its earliness and bright appearance make it protitable.

Thompson's Early Proliflc Red Raspberry has beaten the record here for earliness. It is an enormous grower and stood the winter the best of all that I had.-J. F. WILson, Clarke Co., Ind.

Doz., 50c; $100, \$ 3.00 ; 1000, \$ 20.00$.

Smith's Prolific.-A new blackcap from western New York which has been highly praised. The principal points of meritand superiority claimed for it are canes of strong growth, perfect hardiness and great productiveness. The canes throw out numerous lateral branches which enable them to bear large crops of fruit without danger of breaking down. The berries are borne in large clusters, and are about the size of Gregg, of a bright black color, very flrm, of good flavor. It is also said to be a profitable drying sort, three quarts of berries making a pound of dried fruit. Its season is about second early or between Souhegan and Ohio. Doz., $\$ 1.50 ; 100$, $\$ 10.00$.

Jackson's May King.-A blackeap that has been especially recommended for its earliness, but which we flnd to be really no earlier then Souhegan and not so fine a variety. At Monmouth it is in no way superior to the old, discarded Doolittle, and unless it behaves very much better elsewhere it is certainly not worthy of being placed on the list of standard sorts. Doz. $\$ 1.00 ; 100, \$ 5.00$.
Thompson's Early Proliflc ripened with me this year May 29th. It is proliflc, hardy, large, firm and of the best quality.-J. S. NEWMAN, Director, Alabama Experiment Station.

Palmer. - An early blackeap differing from Souhegan so slightly as to be barely perceptible. The fruit may possibly average a trifle larger but no other points of difference can we distinguish. Its superlority over Souhegan in productiveness, vigor of growth, and quality of fruit, as has been claimed, is not apparent here. At the same time it is necessarily, from its resemblance to Souhegan, a fine early variety and may safely be planted in place of that sort. Doz., $50 \mathrm{c} ; 100, \$ 2.00 ; 1000, \$ 15.00$. closely in size. It has canes of much vigor and hardiness and is decidedly productive. The berries are large and tine in quality. Il ripens about with Gregg and may be regarded as an acquisition. Doz, 50c; $100, \$ 2.00 ; 1000, \$ 12.00$.

Cromvell.-A blackeap of the Souhegan class which variety it much resembles. The fruit is fully equal to it in size and quality, and in hardiness of cane. It is a vigorous grower and productive. Can be safely recommended as a valuable sort. Doz. 50c; $100, \$ 2.00 ; 1000, \$ 15.00$.
Ada.-A promising blackeap approaching Gregg 


\section{GENERAL IIST.}

(The illustrations are one-quarter natural size).

If to be sent by mail add 10c. per doz., 40c. per 100; at 1000 rates by freight or express only.

Brandywine.-This once popular berry is now ries of large size, bright crimson, good quality and superseded by Cuthbert and others. Its bright crim- firm. Upon strong soil the yield is very large and in som color, good size and firmness, render it valuable some locations it is regarded as the best of all. Doz., for market, but it lacks vigor of cane and is onty pro- $35 \mathrm{c} ; 100, \$ 1.00 ; 1000, \$ 8.00$. ductive on good soil. It is very attractive, and grown to some extent. Doz., 35c: $100,1.00 ; 1000$. $\$ \$ .00$.

CUTHB ERT (Qneen of the Market). -The

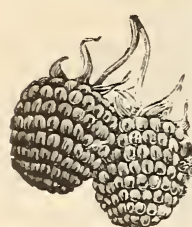
leading late market variety and best red raspberry in cultivation. No other of its class has proved of such general adaptability and it is grown successfully in nearly all parts of the United States and Canada. The canes are hardy and of strong rampant growth, with large, healthy foliage, and exceedingly productive. Berries large, dark crimson, quite flrm and of good flavor. More largely grown than all the other red raspberries combined. Season late. Doz., 35c: 100, \$1.00: 1000, \$\$.00.

GOLDEN QUEEN. -The best yellow rasp-

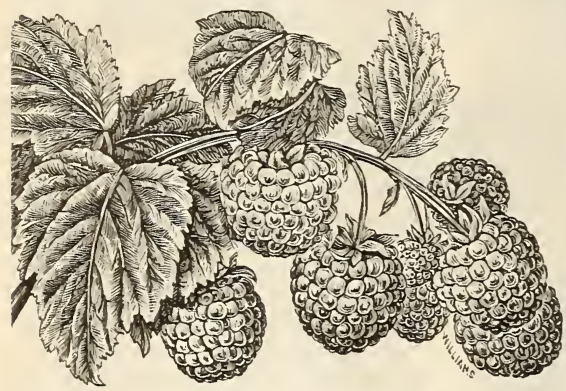

MARLBORO, - The largest of the early red raspberries, ripening a few days later than Hansell. Whilst this is one of the best red raspberries for the North it will not endure hot suns or southern skies, being evidently of foreign parentage. The canes are hardy and fairly productive. Fruit exceedingly

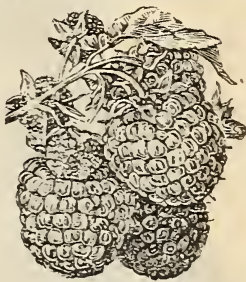
large, bright crimson, and of fair quality. Under proper conditions, viz., cool, northern exposure, it may be considered the best early hardy raspberry. Doz., 35c; $100, \$ 1.00 ; 1000, \$ 8.00$.

Ohio or Alden (Cap).-This is a popular sort in western New York for evaporating purposes, being exceedingly productive and the fruit retaining its flavor and shape better than most other varieties; it is also said to require less fresh berries to the pound of dried fruit. The berries are of good size, of clear shining black and good quality. Ripens in midseason. Doz., 35c; 100, $\$ 1.00 ; 1000, \$ 8.00$.

PROGR ESS (Pioneer). - In some respects simllar to Souhegan but its canes are of much stronger growth and its yield is even greater. It is entitled to high rank among blackcaps and is a most profltable market sort. It is entirely hardy. Berries jet black, very firm and of good quality. It has been largely grown by practical fruit growers and has proved one of the best early sorts ever introduced. Doz., 40c; $100, \$ 1.50 ; 1000, \$ 9.00$

Shafter's Colossal.-An immense raspberry Cuthbert, of large size, great beauty, high quality, hardy and productive. It is of a beautiful translucent amber color and exceptionally flrm. The canes are of the strongest growth and succeed admirably at the South and in California. It is a most valuable raspberry for the amateur and no home garden is complete without it; its beauty, size and fine quality render it indispensable for table use. Ripens in midseason. Doz., 50c; 100, \$2.00; 1000, \$15.00.

GR EGG $(\mathrm{Cap})$. - The leading late blackeap and

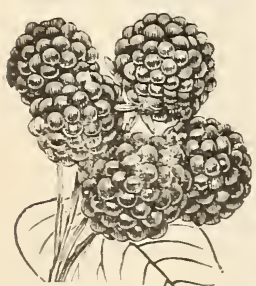
a popular market sort.Canes of strong vigorous growth and under good culture, very productive. Berries verv large. covered $\pi$ ith heavy bloom, flrm, meaty, and of fine flavor. It requires good strong soil to produce best results and responds liberally to generous treatment. It is not entirely hardy but suffers during unusually hardy winters. Doz., 35e; 100, \$1.00; 1000, \$8.00.

Hansell.-The earliest red raspberry. Profitable on account of its extreme earliness, bright attractive color and firmness. Canes rather small, but exceedingly hardy and productive: with tough, healthy foli age, enduring the hottest suns with impunity. Ber-

both in cane and fruit, and especially adapted to the South. Canes are of wonderful vigor and size, hardy and enormously productive. Berries are large. of a dull purplish, unattractive color, rather soft, but luscious and of a rich, sprightly flavor, whilst its color and lack of firmness renders it unfl for market purposes. It is unrivaled for family use and for canning. Late. Doz., 35c: $100, \$ 1.50 ; 1000, \$ 12.00$.

SOCHEGAN or TYLER.-A very early blackeap and the leading early market sort. It ripens its entire crop in a very short period. Canes vigorous and hardy, with foliage healthy and free from rust; wonderfully productive. Fruit of good size, jet black with but little bloom, firm and of sweet pleasant flavor. Doz.,

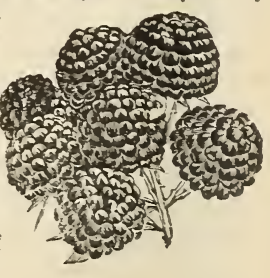
$35 \mathrm{c} ; 100, \$ 1.00 ; 1000, \$ 7.00$.

Turner (Southern Thornless).-Extremely har$d y$ and desirable as an early sort for the home garden, but too soft for market purposes. The canes make a strong, healthy growth and are very productive. Berries of good size, bright erimson color, soft and of honered sweetness. Early. Doz., 35c; 100 , \$1.00; $1000, \$ 7.50$. 


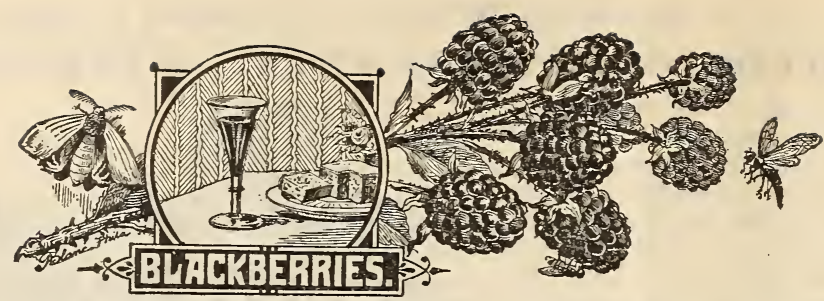

Culture.-Many kinds of blackberries will succeed, not only on good fruit land, but even on the most sandy, porous soil. They require the same treatment as recommended for raspberries, but in fleld culture should be planted in rows five to seven feet apart (according to the strength of the variety), and three feet distant in the rows; in garden culture plant rows five feet apart and plant three feet distant in the rows. The pruning should be governed by the growth of cane and snould be severe. Pinch back the canes in summer when three feət high, causing them to throw out laterals. While we exercise every care in diggring and assorting ordinary plants, known as "Suckers," putting in none without side roots, yet we desire to impress upon the minds of planters the superior value of plants grown from pieces of roots termed "Root Cutting Plants" which, having to depend on their own roots for support, make much better and more numerous laterals and flbrous ones. Root-cutting plants are so vastly superior, and the difference in cost is so slight, that fruit growers who have once planted them will not use suckers at any price when others can be had.

\section{NEW VARIETIES.}

(If to be sent by mail, add 10 cents per dozen; 50 cents per 100.)

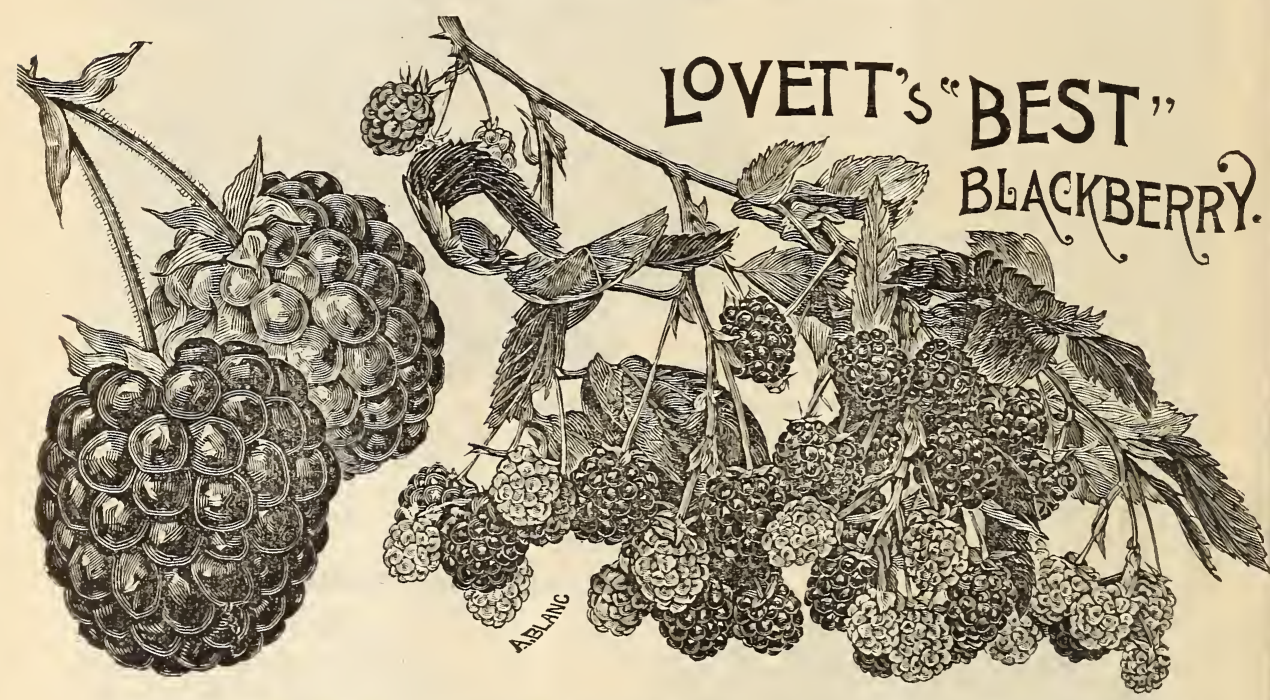

As the "old reliables" have of recent years proved so unreliable, the Kittatinny, Lawton, etc., being so generally effected by "orange rust" and the Wilson by double or "rose blossom" we have for quite a long time been in search of a blackberry to fill the place made vacant by their fallures and also suffleiently hardy as to endure severe weather without injury. After testing a score or more varieties, all of which were claimed by their originators to possess the desired properties, we are happy to be able to announce the advent of Lovett's Best, which we have full confldence will prove a success throughout America wherever a blackberry of any kind can be made to grow. Like the Kittatinny and the Wilson it is a chance seedling of New Jersey origin and, after watching it for several years anc fruiting it two seasons we are convinced that as a general purpose berry it will "flll the entire bill." Its strong points are: enormous yield, great hardiness of cane and freedom from disease (we have had it growing by the side of and surrounding plants badly affected with "orange rust" and it has never taken the disease nor been attacked by any other malady). Its other merits are earliness in ripening, large size, uniform size and shape, jet black color (never turning red after gathered), fine appearance and exquisite quality. Its season of ripening is second early, giving its flrst picking with the second picking of the Wilson and in advance of Kittatinny, Lawton, etc.

It has been subjected to a field test by the originator and some of his neighbors, by the side of Wilson and other popular sorts, for the past six years, surpassing in yield and proflt by far all others, each and every season. It has been exposed to a temperature of several degrees below zero and has never had even its terminal buds injured in the least.

All things considered it is the best variety upon our grounds and approaches more closely the ideal blackberry than any other we have seen.

Price, root-cuting plants, each, 50c; doz., \$5.00; $100, \$ 35.00$. 


\section{J. T. Lovett Co.-Blackberries.}

\section{CHILDS EVERBEARING TREE BLACKBERRY (Topsy).}

"For a blackberry it is the largest, finest flavored, most proliflc, fruiting for two months and requirs no stakes. This fine - novelty $* * *$ is surely one of the most desirable new things we ever offered, and what we say of it we speak from what we have seen and what we have tested, and not from what others say. It grows from 5 to 7 feet high, branching freely into a fine tree form ** straight and erect, requiring no stakes. The berries are of enormous size, equalled only by the Erie; borne in great clusters which commence to ripen early in July and continue into September, making its fruiting period fully two months or more. The finest Blackberries we ever ate we picked about Seutember first from some of these plants which had been ripening fruit since July 8 th. They are exceedingly sweet, juicy and delicious, melting in the mouth without a particle of hard core. Its delicate flavor, great productiveness, enormous size, long season of bearing and perfect hardiness in the coldest part of the country, make it the most valuable of all berries for family use.

"Mrs. C. A. Barton, Santa Ana, Cal., says: "Received the Wineberry and Tree Currant; they are growing finely. If they do as well as your Tree Blackberry I shall be more than pleased with them. Have taken up all other Blackberries as we want nothing but the Tree." -Childs' Catalogue.

Considerable has appeared of late in the horticultural press respecting this prodigy; and although it possesses many valuable properties we cannot fully endorse all that is said of it in the above description. We first propagated and brought to notice this remarkable sort and now have a large stock of fine plants of it.

\section{Foot cutting plants, ea.,} $25 \mathrm{c}$ dozen, \$2.50; 100 , $\$ 15.00$.

Early King. - We are glad to notice that the $\mid$ its value and it is admirably adapted to that purpose

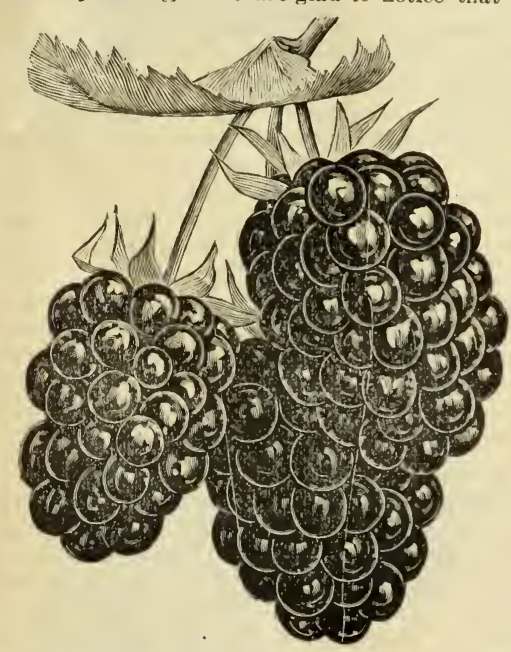

great merits of this blackberry for the family garden are becoming more generally recognized and the variety growing in demand more and more each season. We have predicted its popularity well knowing by reason of its delicious flavor and abundant supply of fruit. The canes are of strong growth and as hardy as Snyder. Berries are not of the largest size but are larger than Early Harvest and much better in quality. We are sure it will give satisfaction to those seeking an extra early, hardy, blackberry, and we can conscientiously advise its planting this fall in the home garden. Root Cutting Plants: Doz., 60c: $100, \$ 3.50 ; 1000, \$ 25.00$.

Thompson's Early Iammoth.-Resembles Wilson's Early very closely both in fruit and foliage, but claimed hy the originator to be perfectly hardy, and earlier than that well-known variety. It is immensely productive and succeeds admirably at ts home near Cleveland, 0 . If it proves everywhere as hardy and as successful it is certainly of value. It grows as a low bush, half tralling, and will run on the ground from 8 to 15 feet, if not kept pinched back-somewhat similar to the (17)

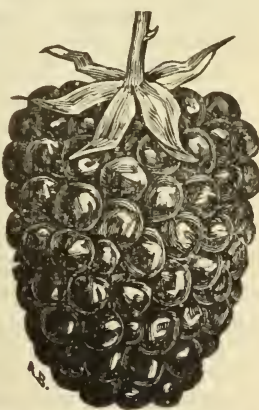
growth of the Dewberry. Doz., $\$ 1.00 ; 100, \$ 5.00$. 


\section{GENERAL IIST.}

(If to be sent by mail. add 10 cents per dozen; 50 cents per 100 additional for postage). Prices are for Root Cutting Plants unles otherwise noted.

Crystal White.-A white blackberry! The

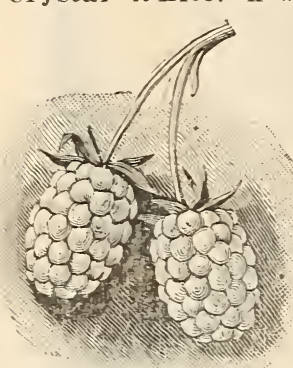

$100,32.00$.

EARLY HARVEST. -The earliest black-

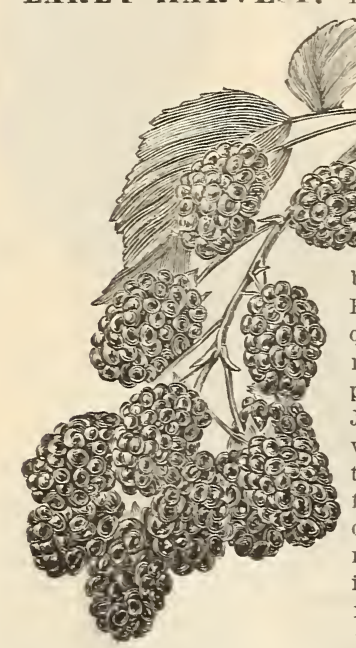

berries are of a flne transiucent white; of goud size, very sweet and pleasant. Canes are of a very pale green color, of strong growth, exceedingly prolific but not entirelyhardr. Should be plant ed contiguous to some other variety, as its blossoms are pistillate. Doz. 50c:

berry except Early King and consequently one of the most valuahle. Ripening the 4 th of July at Monmouth. with its very attractire appearance, firmness and exceeding productireness, renders it eminently prcfitable for market: whilst its earliness and good quality make it a favorite in the home garden. The berries are not of the largest size, but rery uniform and of a bright glossy blackness that renders them extremely enticing. For the South its value can scarcely be orerestimated. and its early ripening brings it into market at a time when it has no competitors. The statement has been made by some that this rariety is not hardy, and we find it explained by the fact of Brunton's Early baving been sent out in many instances by unscrupulous parties for it. Doz., 35c; 100, $\$ 1.00 ; 1000, \$ 8.00$.

LA WTON (Neu Rochelle.)-An old favorite, esteemed for its productiveness and large size. Delicious when fully ripe.but turns black in advance of ripening. Season medium to late. Doz., 50c; 100 , $\$ 1.50 ; 1000, \$ 10.00$.

Iinnewaski. - An early blackberry of considerable value in the neighborhood of its home in the Hudson River fruit district. It has not been planted so largely as many other sorts and is perhaps not so well adapted to such a wide range of country, but it possesses sufticient good qualities to render it valuable both for market and for the home garden, Its canes are hardy and productive and the fruit is large and of good quality. Doz., 50c; $100, \$ 3.00 ; 1000, \$ 20.00$.
ERIE.-The most popular of all the standard

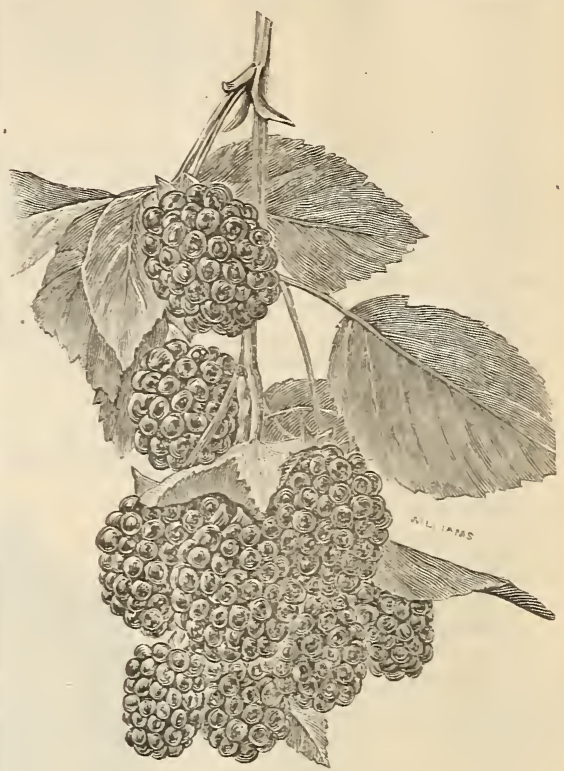

blackberries and has now superceded all other kinds. For sereral seasons past the demand for plants of this rariety has been so great that we have been unable to supply them in sufficient quantity. The canes are of ironclad hardiness, of the strongest growth, quite free from rust, double blossom and all other diseases, and wonderfully productlve, bending the robust canes to the ground with the weight of fruit. The berry is of the rery largest size, exceeding the Wilson. Kittatinny or Lawton, of excellent quality, handsome and firm. In shape it is almost round, which gires it the appearance of being larger than it really is, and very uniform both in size and shape. The Erie somewhat resembles Larton in habit of growth and shape of berry, but a careful comparison shows them to be quite distinct. In season of ripening the Erie is much earlier than Lawton, the canes are more vigorous in grow th and rery much hardier. There is no standard blackberry that equals it in the possession of the four important properties of hardiness, large size, earliness and productireness, or that will compare with it for general planting, either for market or the home garden. Doz., 50c; $100, \$ 2.50$; $1000, \leqslant 20.00$.

Kittatinny. - Once the most popular of all blackberries for general planting and it is still rery fine for main crop, in the home garden, or for market in some locations, but it is not safe from winterkilling north of the latitude of New York Cits, and of recent jears it has become badly affected with the "rust" or blackberry fungus. The berries are large, handsome, and of delicious flavor: canes of strcng, erect growth and productive. Season medium to late. Doz., 35c; $100, \$ 1.50 ; 1000, \$ 10.00$. 


\section{J. T. Lovett Co.-Blackberries-Dewberries.}

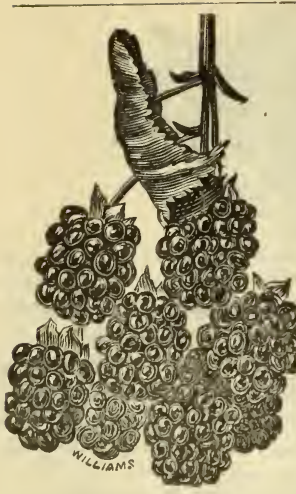

SN Y D ER. - Valuable for the north by reason of its extreme hardiness. Wonderfully productive, and though the berries are but small to medium in size,they are of sweet juicyflavor.and when fully ripe without the hard core of many other sorts. Until the appearance of the Erie this was the standard early sort for the North and Northwest and is still very popular, being more largely planted than any other of the fron-clad varieties. Doz., 35c; $100, \$ 1.25 ; 1000, \$ 9.00$.

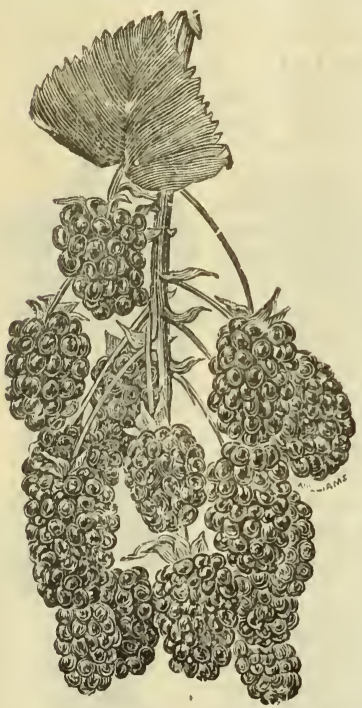

r a y 10 r's P rolific. $-A$ suitable companion for Snyder, for it is also a variety of great hardiness and productiveness, but ripens somewhat later. Berries are very much larger and of tne flavor. Canes of strong growth and ironclad hardiness. of especial value for planting at the North and desirable for its fine flavor Its large size, great hardiness and wonderful productiveness render it of greatest value for the North. Season medium. Doz., 40c; 100, \$1.50: 1000, $\$ 10.00$.

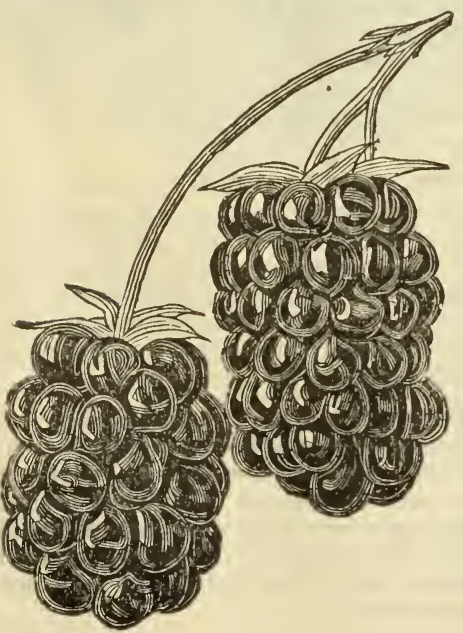

Wilson Junior.-Takes the place of the old-

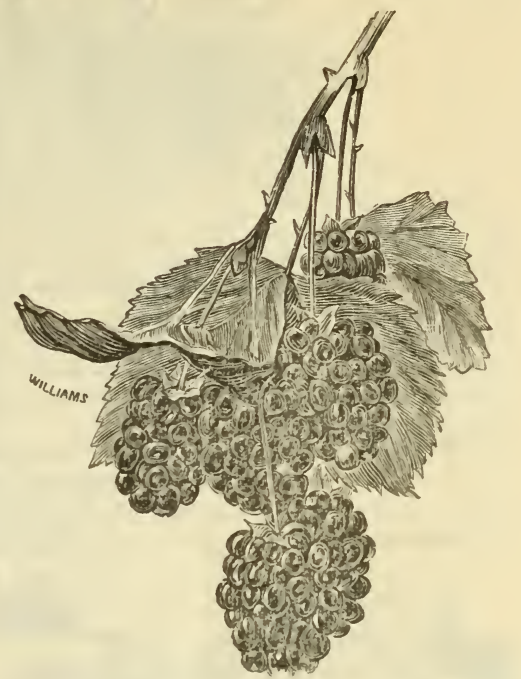

Wilson's Early; it possesses all its good qualities and is hardier and more productive, combining size, earliness and productiveness with the fine appearance and market properties of that variety. It is also without double or rose blossoms. The fruit in all respects fully equals that of its parent, Wilson's Early, which it has now completely superseded; holds its bright color and carries weil to market. It proves entirely hardy in New Jersey, withstanding the winters here without injury, quite unprotected. Doz., $50 \mathrm{c}, 100$, $\$ 1.50 ; 1000, \$ 10.00$.

Wilson's Early. -A well known varlety, once the leading early blackberry and still a popular market sort in many sections. It has now become enfeebled by disease and there are few sources from which healthy plants may be procured, hence it has been pretty generally superseded by better sorts. Suckers: Doz., 35c; 100, \$1.00; 1000, \$7.50. Root Cutting Plants: Doz., 50c; 100, $\$ 1.50 ; 1000, \$ 10.00$.

\section{DEWBERRIES.}

The Dewberry has thus far not been cultivated to any great extent on account, perhaps, of the few varieties that are worth growing. There is no reason, however, why people should not enjoy this wholesome fruit, especially as it comes at a seascn between the raspberries and blackberries. The best mode of culture is to treat it somewhat like the strawberry and plant it in rows six feet apart with the plants three feet distant in the rows, or setting the plants four feet by four. Keep the soil mellow and clean.

LUCRET A . - Decidedly the best of all dewberries. As early or earlier than Early Harvest blackberry and larger than Erie. It is a superb fruit; large and handsome, of a shining jet black, melting and of a delicious quality. The plant is entirely hardy everywhere, a healthy, strong grower, and exceedingly productive. We can confldently recommend the Lucretia as being a flne acquisition to the family garden and a delightful introduction to the blackberry season. The accompanying illustration represents medium sized berries. Root cutting plants: Doz., 40c; 100, $\$ 1.50 ; 1000, \$ 10.00$. (If to be sent by mail add 10c. per doz., 50c. per 100 for postuge). 


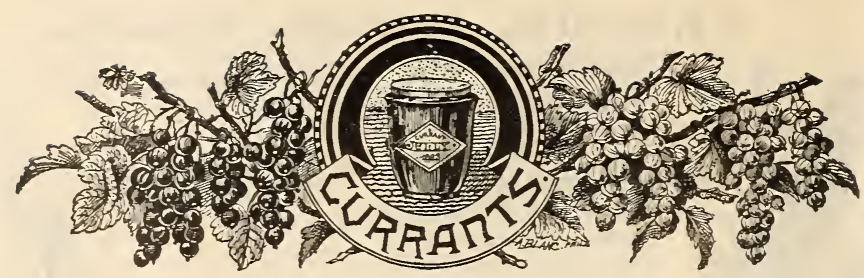

Culture.-A cool, moist location is best for this fruit, and for this reason it succeeds admirably when planted by a stone wall or fence; being beneflted by partial shade. Plant in rows four feet apart, and the plants three feet apart in the rows. Keep the ground mellow and free of weeds and grass; using fertilizers copiously. Mulching is necessary for the best returns. So soon as the leavos turn yellow and begin to fall, with a pruning knife remove all the old wood and cut back the young shoots a third of their length-cutting to the ground enough of these to admit air and light into the bush freely. When the currant worm appears dust the bushes with Buhach or tobacco dust; it can be exterminated also by dissolving powdered white hellebore (to be had at any drug store) in the proportion of an ounce to a pail of water, and applied with a syringe upon the leaves.

Prices: 1 yr.. doz., 60e; 100, \$3.00. 2 yrs., doz., g5e; $100, \$ 4.00$; except as otherwise noted.

(1 yr. by mail at 10c. per doz.: 50c. per 100 additional. Two years old plants are too large to be mailed). Crandall. - A purely native American currant,

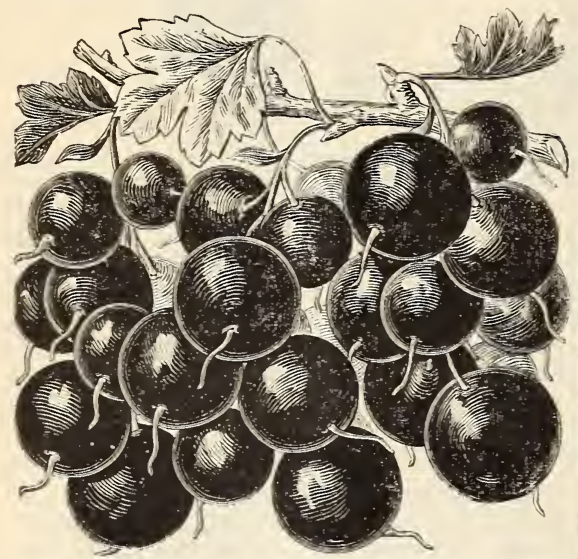

quite distinct from the European black currant and without a trace of its strong odor. This is the best variety of this species yet introduced. The bush grows to a height of four feet or more, is perfectly hardy and immensely productive, the branches being invariably loaded with fruit. The berries are large. many of them being one-half inch in diameter and some even larger, intensely black and of a fairly good quality. It is excellent when cooked and is well adapted for sauces, pies, jams; etc. No insect enemies have been found to defoliate it and it is entireIy exempt from the attacks of the Currant Worm. Strong Plants, doz., \$1.25: 100, si.00.

Red Dutch.-The old well-known currant of our boyhood. Berries small, but of the finest quality and produced in the greatest abundance. Best of all the red varieties for making jellies and wines.

Lee's Prolific. -The best European black currant yet introduced, and oue that marks a great advance in the fruit of its class. It is earlier than Black Naples, and of superior quality; larger, longer clusters and even more productive than that prolific kind.

Black Naples.-Similar to the preceding in a general way.

NORTH STAR.-A valuable new red currant of much promise, large, fine and exceedingly productive. 1 yr., ea., 50c; doz., $\$ 5.00$.
FA Y'S PR OLI FIC. - Has fully sustained the broad claims which were made for it by the disseminator upon its introduction; and it is decidedly the best red currant we have. It has been widely planted and has given general satisfaction. The bush is a strong grower, wonderfully proliflc, and comes into bearing early. Fruit large, bright red, and of good flavor, and less acid than Cherry, which it is rapidly superceding. Those who want a profitable red currant and do not plant this variety are missing a valuable opportunity. 1 yr., doz., \$1.25; 100, \$7.0 . 2 yrs., doz.. \$1.50; 100, $\$ 10.00$,

CHERRY and VER SA ILLES. - The most popular market sorts, and uniformIv the largest of all red currants except Fay's Prolific. Bunches large, berries very large, bright, sparkling crimson, beautiful, very acid. Bushes of rugged,

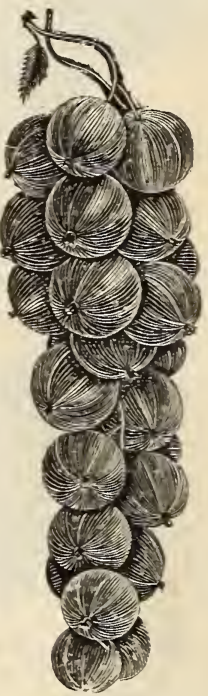

(Much reduced.) vigorous growth and only moderately productive. The two are so very much alike that one description answers for both.

W H I'TE GR A PE.-The largest and decidedly the best white variety, and one of the best of any for the home garden. Bunch large and long; berry large; handsome, translucent white, and of best quality, being less acid than others. Bush free grower and very productive. This is a splendid variety for table use by reason of its beauty and fine flavor, form. ing a lovely contrast to the red varieties.

VICTOLIA.-A splendid variety and very valuable, ripening some three weeks later than the others described. Bunches extremely long, berries of medium size, pale red, and of excellent quality. Bushes good growers and profuse bearers. By reason of its late season it is highly profltable for market and very desirable for the home garden, No collection should be withoutit. 


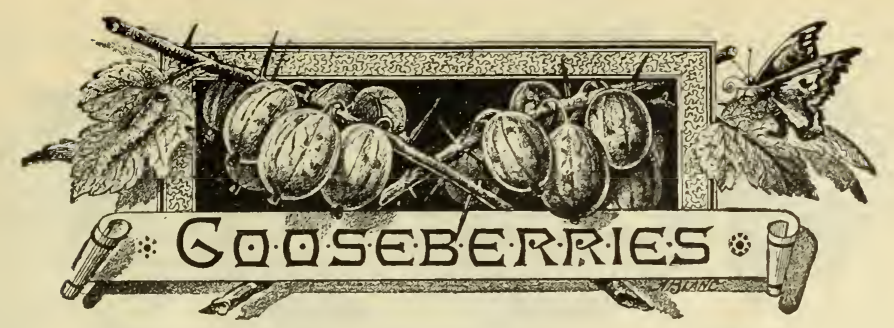

This fruit, so popular, large, לandsome and delicious in Europe, is beginning to receive a little of the attention in America that it well deserves. Like the currant (to which it is closely allied) the gooseberry is a gross feeder and delights in a deep rich soll. Its greatest enemy is "mildew," which, however, is generally avoided by planting in partial shade, as recommended for currants, and by thorough mulching. The currant worm is even more destructive to the g(юseberry than to the currant; and should it appear (it will be recognized by the specimen upon the leaf in the above flgure) treat it as recommended on the preceding page. Plant same distance, cultivate and prune as recommended for currants.

\section{VARIETIES.}

(1 yr. by mail at 10c. per doz.; 50c. per 100 additional. Two year old plants cannot be mailed.) Rates of any sort by the thousand will be given upon application.

IN DUST R Y.-Now generally known. Though

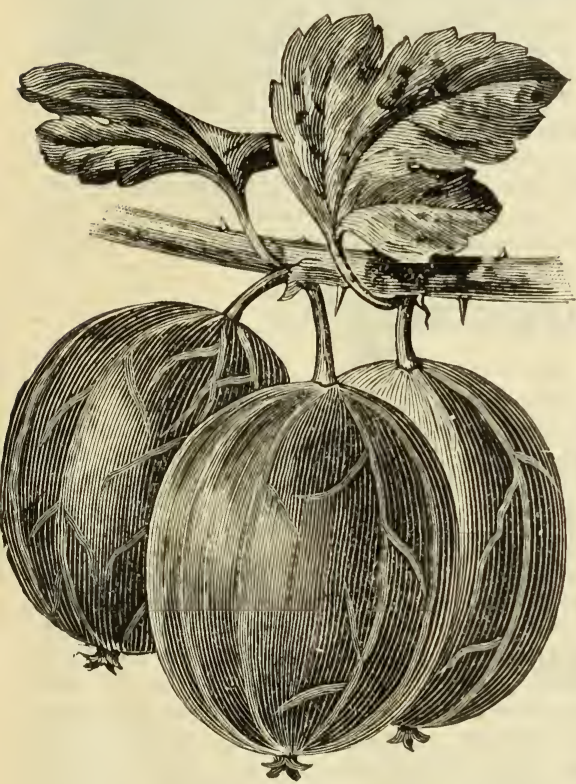

an English variety it succeeds admirably throughout the northern portion of the United States but it is a little impationt of hot suns; and south of New York is not always to be depended upon. Under favorable conditions it bears immense crops and is quite exempt from mildew. It has the peculiar advantage of coming into leaf before it flowers, consequently the foliage protects the bloom from destructive spring frosts. The berl les are exceedingly large, of a dark red or cherry color, with numerous hairs and of delicious quality when ripe. It has been fruited quite largely in this country for several years and has thus far proved unequaled for size, flavor, productiveness and vigorous growth. In cool, rich soil and with a northern exposure it will yield an abundance of large luscious fruit, and it also succeeds well under the shade of trees when not too dense. 2 yrs., ea., 25c; doz., $\$ 2.00 ; 100, \$ 12.00$.
GOLDEN PROLIFIC (new), - An American seedling of the English type and from western New York. The disseminator gives the following desseription: "It is perfectly hardy, a good grower and unusually free from mildew. Its foliage is of a dark, glaucous green, and, in a young state. its wood is very spiny, being very distinct in this respect. Fruit is large, of a deep golden yellow, of excellent quality, and very attractive in appearance. A heavy fruiter and $I$ believe is destined to become as popular as the Industry, and, unlike that variety, it can be propagated successfully." A yellow gooseberry of large size, free from mildew, and perfectly hardy, is indeed an acquisition and will make a delightful companion to the Industry. 2 yrs., each, 50c; doz., $\$ 5.00$.

DO IV N I G. - The best of the American sorts

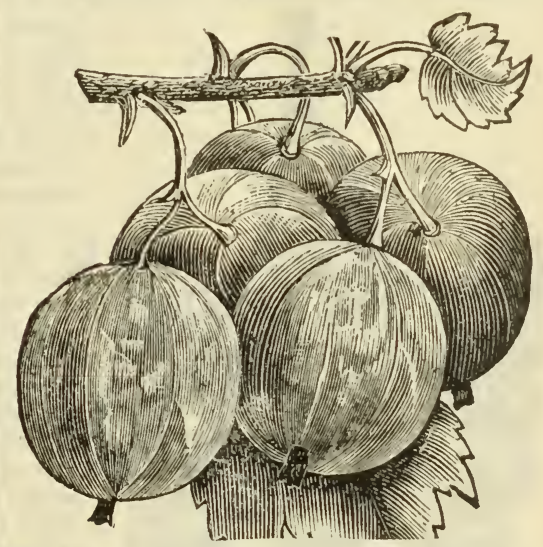

and a vast improvement upon the Houghton, of which it is a seedling. Fruit large, pale green, and of excellent quality, both for cooking and table use. Bushes stocky, vigorous, hardy, very proliflc, and nearly free from mildew, but densely clothed with large, sharp spines. We recommend this as the best for general planting. $1 \mathrm{yr}$, doz., 60c; $100, \$ 4.00$. 2 yrs., doz., 75c; $100, \$ 5.10$.

HOUCHTO N. - The old well-known sort. Berries small, pale red, sweet and gnod; bushes vigorous, productive, and reliable. $1 \mathrm{yr} .$, doz., $50 \mathrm{c} ; 100$, $\$ 3.00$. 2 yrs., doz., 60 c; $100, \$ 4.00$. 


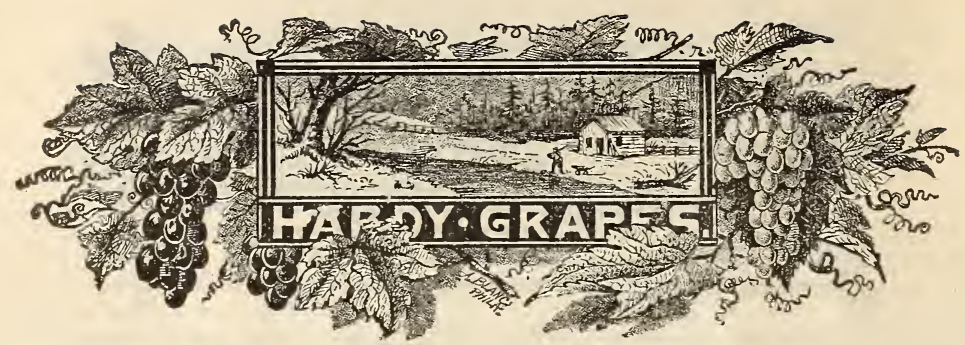

Culture. - The limits of a catalogue do not permit more than brief mention of modes of cultivation.

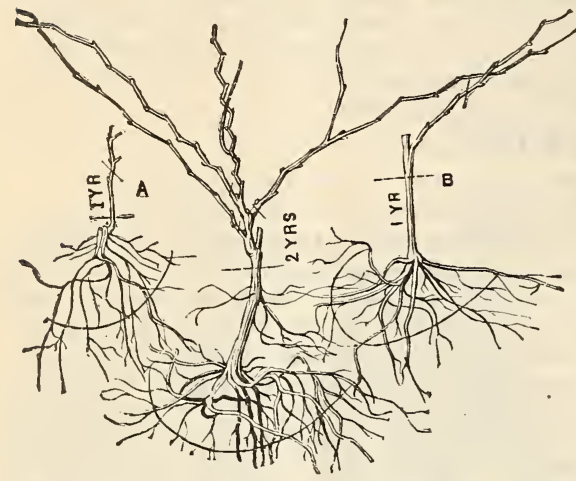
of"the"grape vine." We refer the reader to the excellent works of Fuller and Hussman for full details. Plant in rows six feet apart and eight feet apart in the row. Dig holes sufficiently large to amply accommodate the roots of the vine and use only flne surface soil in flling in, mixing with it a lit.tle ground bone. Cut back one year vines to two eyes, placing the lower one beneath the surface; cut back two year vines to three or four eyes, putting two or three eyes below the surface. Spread the roots out, after trimming them, as in the accompanying figure, place the stock of the vine at one side of the hole and fll up with fine soil pressing down firmly with the feet. Set a stake by the side of the stock, to which the vine should be kept tied, which will be all the support needed for two years. Keep old wood trimmed off, growing fruit or new canes. Any manner of pruning that will admit the sun and air to the fruit will insure a crop. For mildew, dust with flowers of sulphur while the

$A$ is a one-year vine grown from a single eye. $B$ une-year vine grown from a cutting. leaves are wet.

\section{NEW VARIETIES.}

(By mail postpaid at each and dozen rates.)

GREEN IIOUN'TA IN.-A very fine, early white grape ripening about with Moore's Early.

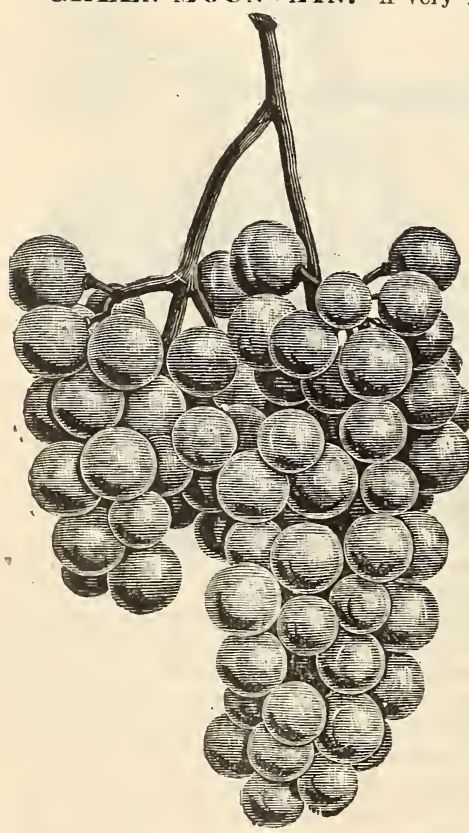

GREEN MOCNTAIN. Clusters are of medium size and often shouldered; berries a little larger than those of the Delaware,greenish-white when fully ripe, skin thin and quality fine, pulp being tender and sweet, quite free from foxiness. The vines are of vigorous growth and apparently quite hardy.

The introducers, who have grown this grape for several years, say of it: "We do not believe there is an early grape superior to it in quality, that bears younger, is more productive, or that is more desirable for an early grape than this one. It has not failed to produce or ripen a full crop in the three years we have tested it. The vine grows as strong as the Concord, and will flourish in any soil where the Concord grows. It is especially well adapted to be grown in northern localities where many valuable varieties sometimes fail, or perhaps never ripen; and in those localities where these sorts do ripen, the Green Mountain is equally desirable as it will lengthen the grape season by reason of its earliness. The past season was one of extreme wet here and was universally noted for mildew and grape-rot, thus causing an almost total failure in the grape crop, yet our Green Mountain vines were loaded with large, handsome bunches, Aug. 25th, and were a wonder and admiration to all who saw them." 1 yr. ea. 75c.; doz. \$7.50: $100, \$ 50.00$. 2 yrs. ea., $\$ 1.00$; doz. $\$ 10.00 ; 100, \$ 75.00$.

Colerain.-A seedling of Concord, of high quality, very juicy and remarkably sweet, in fact the best early grape we have eaten. Both bunch and berry are of medlum size, bunch shouldered, of a light green color with delicate white bloom, thin and tender skin and an almost total absence of seeds. The vine is a strong, vigorous grower, seemingly free from disease and entirely hardy. It is claimed by the originator to be an abundant bearer and it ripens from the 15 th to the 30 th August. 1 yr. ea., $\$ 1.00 ;$ doz. $\$ 10.00 ; 2$ yrs ea., $\$ 1.50$; doz. $\$ 15.00$. 


\section{J. T. Lovett Co.-Grapes.}

MOORE'S DIA MOND.-A pure native, being a cross between the Concord and Iona. Vine a

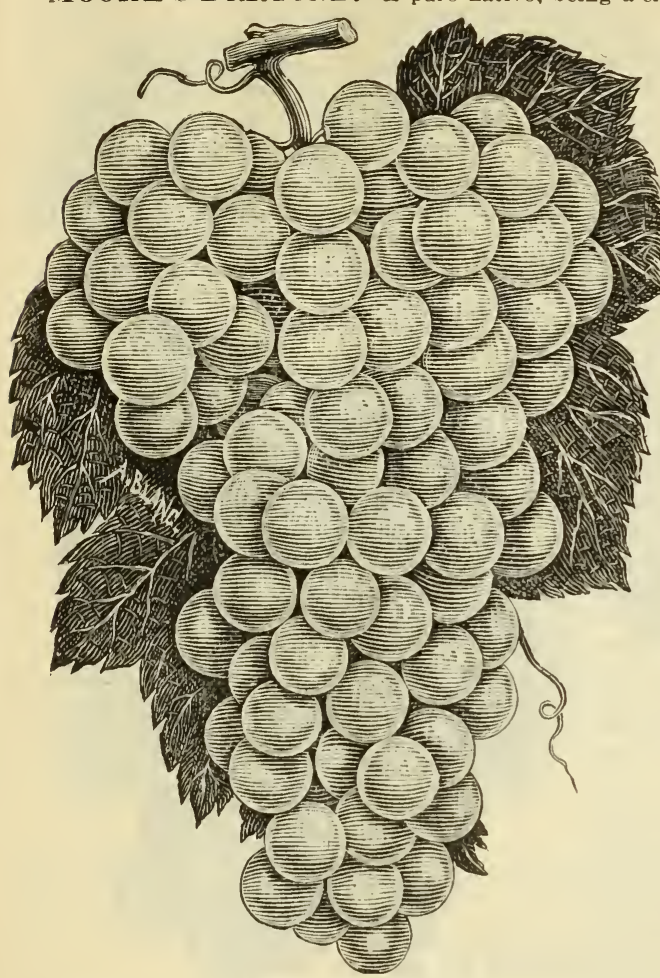

MOORE'S DIAMOND. vigorous grower, with Jarge, dark, healthy foliage, which is entirely free from mildew. The parent vine has been in fruiting for several years past, near Rochester, N. Y., without the least protection, ripening its wood and coming out sound and bright to the very tip every spring, even during severe winters, when other varieties considered hardy have killed badly. Other vines propagated from it have proved equally hardy and healthy with only ordinary cultivation, in the open fleld. It is a prolific bearer, producing large, handsome, compact bunches, slightly shouldered. The color is a delicate greenish-white, with a rich yellow tinge when fully ripe; skin smooth, very few seeds. juicy and almost entirely free from pulp, which makes it almost transparent when held to the light. Berry ubout the size of Concord, and adheres firmly to the stem. It ripens early, usually from August 25 th to September 10th, in the latitude of Rochester, N. Y.

"In my opinion, 'Moore's Diamond' is the finest white grape, all points considered, that has yet been produced in this country - far superior to Nlagara or Pocklington, which are coarse in comparison with it. It ripened with meabout $v$ ith the Delawares." - Editor Vick's Magazine.

"I consider the variety superior, every way, to other varieties of its season and blood (Labrusca) now before the public, $\mathrm{ri}^{-}$ pening early.-T. V. MUNSON.

1 yr., ea., 20c.;doz., $\$ 1.50 ; 100, \$ 10.00$. 2 yrs. ea., 25c.; doz., \$2.00; 100, $\$ 15.00$.

EA'TON. - A seedling of Concord but claimed of more vigorous growth, auite as productive, with larger and better fruit. Bunch very large, compact; berries very large, round, black, covered with a thick blue bloom. The stem pulls out white like the Concord. The general appearance of the bunch and berry strongly resembles that of Moore's Early. The skin is quite as thick as that of the Concord. Very juicy with some pulp, though tender. Not as sweet as the Concord but has less of the native odor. Season early. It is a handsome grape and has been grown to weigh one pound six and one half ounces the largest berry measuring an inch in diameter. It has been favorably noticed by both the Amer. Pom. Society and the Mass. Hort. Society. 1 yr. ea., 35c; doz., $\$ 3.50 ; 100, \$ 25,00$. 2 yrs., ea., 60c; doz.. $\$ 6.00$; $100, \$ 40.00$.

\section{GENERAL LIST.}

If by mail add 10c. per doz., 50c. per 100 for one year, and 15c. per doz., 75c. per 100 for two years, for

postage; at single rates post frce.

Aga va an (Rogers' 15).--A flne, large, red grape; cluster of good size; quality excellent, with a decidedly aromatic flavor peculiar to the variety. Vine a strong grower, productive, and with good foliage for a hybrid. Midsenson. 1 yr., ea., 10c; doz., 50c; 100 , $\$ 3.00$.' 2 yrs., ta., 15c; doz., 75c; $100, \$ 4.00$.

Bacelnus. - An improvement upon the old and popular Clinton, from which it is descended. A good table grape, but its great value is for wine making. Both bunch and berry small, compact, black. Midseason. 1 yr., ea., 10c; doz., 50c; $100, \$ 2.50$. 2 yrs., ea., $12 \mathrm{c} ;$ doz., $60 \mathrm{c} ; 100, \$ 3.50$.

Berckman..-A hybrid between Clinton and Delaware, the vine resembling that of the former and the fruit that of the latter. A little larger than Delaware, with which it ripens. Pale red color and of flne quality. 1 yr., ea., $35 \mathrm{c}$; doz., $\$ 3.00$. 2 yrs., ea.. $50 \mathrm{c} ;$ doz.., $\$ 5.00$.
Thousand rates upon application.)

Brighton.-Too much can scarcely be sald in favor of this as to quality and other properties. In color, form, and size of both bunch and berry, it resembles Catawba, but ripens earlier-with the Delaware. Vine a free grower and productive. $1 \mathrm{yr} .$, ea. 10c; doz., 75c; $100, \$ 4.00$. 2 y rs.. ea., 15c: doz., $\$ 1.00$ : $100, \$ 6.00$.

Catawba.-Mildews badly in most locations and ripens too late to perfect its fruit. Bunch large, compact; berries large, round, deep red, flesh sweet, juley, vinuous, slightly musky. $1 \mathrm{gr}$., ea., 10e; doz., $50 \mathrm{c} ; 100, \$ 300$. 2 yrs., ea., 15c; doz., $75 \mathrm{c} ; 100, \$ 5.00$.

Clampion (Talman).- The earliest of all black grapes, and although of very poor quality. it is exceedingly profitable. Bunch medium, compact,shouldered; berries medium, black, with thick skin, firm. $1 \mathrm{yr}$, , ea., 10c; doz., 50c; 100, \$2.00. 2 yrs., ea., 12c; doz., $60 \mathrm{e} ; 100, \$ 3.00$. 
Clinton.-Clusters and berries small; quality pleasant to some and objectionable to others. Vine a strong grower, and never fails to produce a crop, but rarely a heavy one. Valuable for wine. Color black; season late. 1 yr., ea., 10c; doz., 50c; 100, $\$ 2.00$. 2 yrs., ea., 12c; doz., 60c; $100, \$ 3.00$.

Concord.-So popular and well known as to need no description. 'The grape for the peop!e, succeeding everywhere and producing abundantly fruit of good quality. $1 \mathrm{yr}$., ea., $10 \mathrm{c} ;$ doz., $50 \mathrm{c} ; 100, \$ 2.50$. 2 yrs.. ea., 12c; doz., 60c; $100, \$ 3.50$.

Delaware.-In quality most exquisite, but the vine is of feeble growth and especially subject to mildew. Bunch and berry small. Color light red; sweet and high flavored. 1 yr.. ea., 15c; doz., 75c; 100 , $\$ 5.00$. 2 yrs., ea., 20c; doz., $\$ 1.00 ; 100, \$ 7.00$.

Duchess.-Color greenish-white, clusters very long, and usually shouldered; flesh tender, without pulp, juicy, sweet, of flne quality. Vine of exceedingly strong growth and hardy. Season early. $1 \mathrm{yr}$., ea., $12 \mathrm{c}$; doz., 60c; $100, \$ 3.50$. 2 vrs., ea., 15c; doz., $75 \mathrm{c} ; 100, \$ 5.00$.

Early Victor. - Valuable for its flne quality and earliness; ripening a little after Moore's Early. In bunch and berry a little below the average in size, but of superb quality. without pulp or foxiness. Ber. ries black, adhere well to the stem, and have never been known to crack; vine of rampant growth, exceedingly productive. $1 \mathrm{yr}$., ea., 20c: doz., $\$ 1.00 ; 100$, $\$ 6.00$. 2 yrs., ea., $25 \mathrm{c} ;$ doz., $\$ 1.50 ; 100, \$ 9.00$.

Elvira.-A valuable wine grape but also flne for table use. Vine a good grower, healthy, hardy and productive; bunch and berry of medium size, thin skin, pale green with white bloom; sweet, tender and juicy. Midseason. 1 yr., ea., 10c; doz., 50c; $100, \$ 2.50$. 2 yrs., ea., 12c; doz., 60c; 100, \$3.50.

Empire State. - A seedling of Hartford crossed with Clinton. A strong grower, extremely hardy, and i heavy bearer. Clusters large, berry medium, white with a slight tinge of yellow, tender, juicy, sweet, rich. Rifens with Moore's Early. 1 yr., ea., 20 c; doz., $\$ 1.50 ; 100, \$ 9.00$. 2 yrs.,ea.,25c; doz.. \$2.00; $100, \$ 12.00$

Hartford Prolific.-An old, popular grape, very early and reliable. Bunches large, shouldered; berries round. medium, black. Vine healthy, hardy and immensely productive. Its tendency to drop from the bunch impairs its value largely for market growing. $1 \mathrm{yr}$, ea., 10c; doz., 50c; 100, \$2.50. 2 yrs., ea., $12 \mathrm{c} ;$ doz., 60c; $100, \$ 3.50$.

HA Y ES (Francis B. Hayes)-One of the same lot of seedlings from which came Moore's Early. It, also, is early in ripening, and possesses many points in common with that now popular grape. The vine is a good grower; nardy and rugged: fruit large, white and of high qualiiy for a variety of its class. 1 yr., ea.. 25c; doz., $\$ 1.50 ; 100, \$ 10.00$. 2 yrs., ea., $35 \mathrm{c} ;$ doz., $\$ 2.50 ; 100, \$ 15.00$.

Ives.-A popular early market grape. Bunch and berry medium size, black; foxy, and of poor quality until fully ripe. Vine hardy, a strong, coarse grower. Makes a good red wine. 1 yr., ea., 10c; doz., 50c; 100, $\$ 2.50 .2$ yrs., ea., $12 \mathrm{c} ;$ doz., $60 \mathrm{c} ; 100, \$ 3.50$.

Lady.-Ripens early and is deservedly popular. Vine of good growth, productive; bunch and berry of good size, quite pulpy and somewhat foxy, but sweet. and good; skin thin; light greenish-yellow. 1 yr., ea., $20 \mathrm{c} ;$ doz., $\$ 1.25 ; 100, \$ 8.00$. 2 yrs., ea., $25 \mathrm{c} ;$ doz., $\$ 1.75$. $100, \$ 12.00$.
Lady Washington.-Clusters of enormous size, berries large, greenish amber and lacking in quality. Vine of rampant growth, very productive, with good foliage. Late. $1 \mathrm{yr} .$, ea., $30 \mathrm{c}$; doz., $\$ 2.00$; $100, \$ 15.00$. 2 yrs., ea., 40 c; doz., $\$ 4.00 ; 100, \$ 25.00$.

Iartha.-A reliable white grape ripening in midseason, productive and seldom mildews; bunch and berry of good size and handsome, very sweet and pulpy, and quite foxy. 1 yr., ea., 10c; doz., 50c; 100 , $\$ 3.00$. 2 yrs., ea.. 12c; doz., 60c; $100, \$ 3.50$

Moore's Early.-Vine even more rugged than

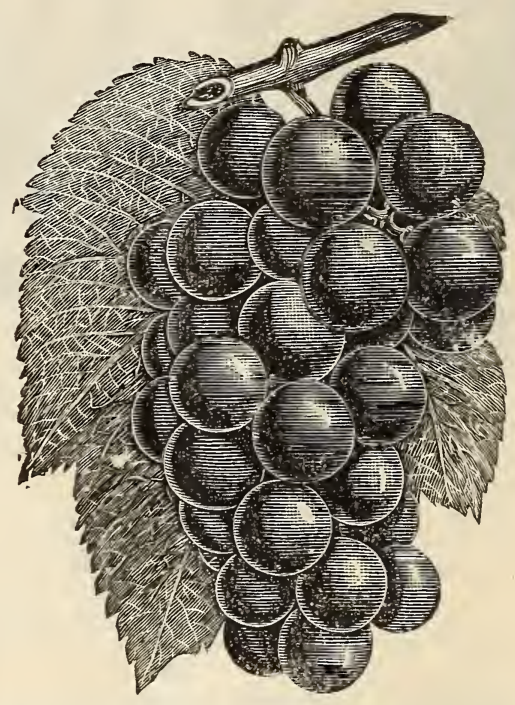

its parent Concord; fruit much larger in berry, but as a rule not so large in bunch; quality almost identical, and it ripens fully two weeks earlier. $1 \mathrm{yr} .$, ea., 10c; doz., 50c; 100, \$3.00. 2 yrs., ea., 15c; doz., 75c; $100, \$ 5.00$. Fruiting vines, ea., 25c; doz., \$2.50; 100 , $\$ 10.00$.

Ioyer.-A profltable market grape at the North and where it succeeds. It is a sort of dark colored Delaware but with a larger berry and bunch and ripening much earlier than that popular sort. It is equal in lavor to Delaware, and the vine is a stronger grower with a better leaf; perfectly hardy in Canada. This was formerly known as the Jordan. $1 \mathrm{yr}$., ea., 60c; doz., $\$ 400$. 2 yrs., ea., 75 c; doz., $\$ 7.50$.

Pocklington.-Vine vigorous, hardy and productive. Clusters large, compact, generally shouldered and showy. Berries large, greenish-amber, turning to golden yellow when fully ripe, round; flesh juicy and sweet, quite foxy. Ripens with Concord. 1 yr., ea., 15c; doz., 75c; 100, \$5.00. 2 yrs., ea . $20 \mathrm{c} ;$ doz., $\$ 1.50 ; 100, \$ 8.00$.

Salem (Rogers' 53).-Very like Agawam in all respects. Popular and good. 1 yr., ea., 12c; doz., $50 \mathrm{c} ; 100, \$ 3.00$. 2 yrs., ea., 15c; doz., $\pi 5 \mathrm{c} ; 100, \$ 4.00$.

Wilder (Rogers' 4 )-Perhaps the finest in quality of all the hardy black grapes. A good grower, productive. Bunch and berries large, pulp soft and tender, rich, vinous and superior. Midseason. $1 \mathrm{yr}$., ea., 15c: doz., $75 \mathrm{c} ; 100, \$ 5.00$. 2 yrs., ea., 20c; doz., $\$ 1.25 ; 100, \$ 7.00$. 


\section{J. T. Lovett Co.-Grapes-Juneberries.}

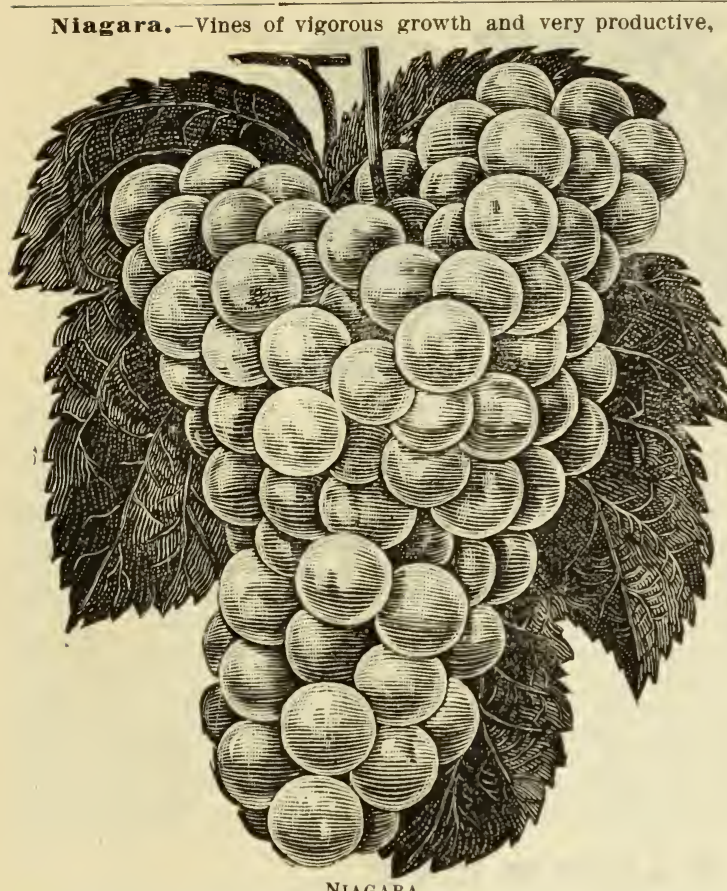

ith tough leathery foliage. Cluster large and compact sometimes shouldered; berry large, round, with thin skin, greenish-white, turning to a pale amber;flesh slightly pulpy,sweet and good. Ripens with Concord. 1 yr., ea., 15c; doz., 75c; 100, $\$ 5.00$. 2 yrs., ea., 20c; doz., $\$ 1.50 ; 100, \$ 8.00$.

Worden (true). - In brief an im. proved Concord, being larger in both bunch and berry, handsomer, nearly two weeks earlier, and of better quality. As it is dificult to propagate, many vines of Concord are sold for it. $1 \mathrm{yr}$, ea., 15c; doz., 75c: 100, $\$ 4.50$. 2 yrs., ea., $20 \mathrm{c}$; doz., $\$ 1.00 ; 100, \$ 6.00$.

WOODRUEF RED. - Vine a very strong grower, free from disease and very hardy. Bunch large, shouldered, berry very large and does not drop from stem. Exceedingly showy and has taken first premium over all competing varieties wherever shown. Of large size, both in bunch and berry, bright red color and general attractiveness. 1 yr., ea., 40c; doz., \$3.50. 2 yrs., ea., 60c; doz., $\$ 5.50$.

Wyoming IRed (Siglar).-An early, light red grape with ironclad vine and foliage; always yielding enormous crops. It ripens with Delaware, which it resembles in appearance, though larger in bunch and berry. A valuable grape. $1 \mathrm{yr}$. , ea., 15c; doz., 75c; 100, \$5.00. z yrs., ea., 20c; doz., \$1.20; 100, \$6.50.

\section{JUNEBERRIES.}

(If by mail add 15c. per doz., 75c. per 100 for postage:)

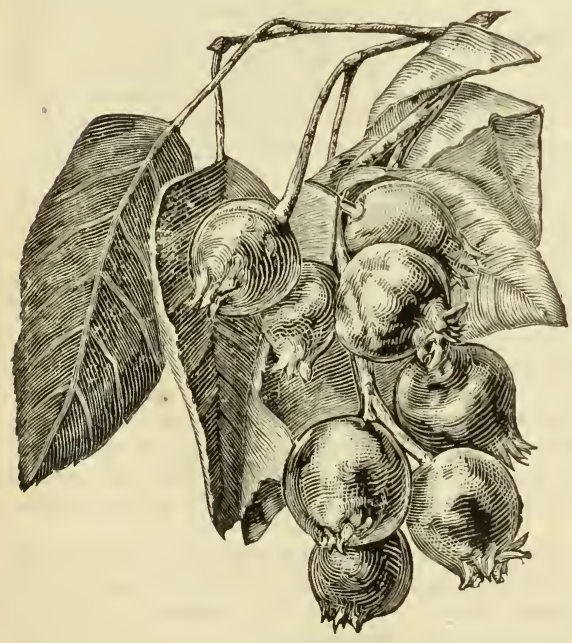

The Dwarf Juneberry is a good! substitute for the large or Swamp Huckleberry or Whortleberry, which it resembles in appearance and quality, but is of the easiest culture. The fruit is borne in clusters, as shown in the engraving, reddish-purple in color, changing to bluish-black. In flavor it is of a mild, rich sub-acid; excellent as a dessert fruit or canned. It is extremely hardy, enduring the cold of the far North and the heat of summer without injury-its only enemy so far developed being a fungus which attacks the fruit and sometimes the foliage at the East. In habit it is simllar to the currant, the bushes attaining the same size. The blossoms are quite large, and composed of flne white petals; which, with its bright, glossy, dark green foliage, render it one of the handsomest of ornamental shrubs. As it grows from suckers, the plants frequently have but little root, but they transplant so readily that they rarely fall to live if planted in the soll firmly.

Improved Dwarf. - Doz., 75 c; $100, \$ 4.00$.

SUCCESS. - This is a superb variety of the juneberry, the result of careful crossing, and a great improvement upon the common dwarf variety. It is perfectly hardy, free from disease and exceedingly proliflc. The fruit is delicious, of a rich and full sub-acid flavor, and is a decidedly valuable acquisition to our list of small fruits. It was produced and introduced by Prof. H. E. VanDeman, U.S. Pomologist, from whom we purchased the entire stock and control of it. We are therefore headquarters for this new variety, having taken the whole of the original stock, and we possess the entire merchantable stock of it in the United States. Purchasers can therefore make certain of obtaining the true "Success" only by sending their orders to us. Doz., $\$ 1.00 ; 100, \$ \tau .00$. 


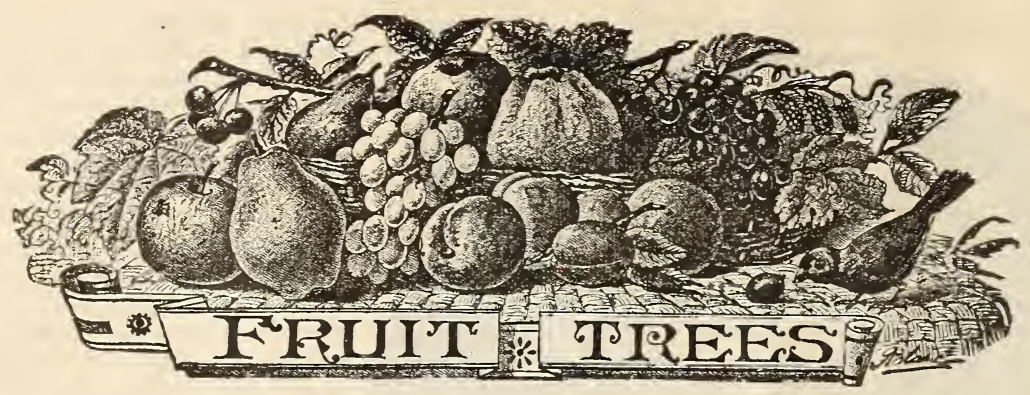

No Fruit Trees can be sent by mail except those so noted.

Packing Free.-Please observe that we carefully pack and deliver to railroad or boat at prices af. flxed. All in need of larger quantities than quoted are referred to Wholesale Price List.

Plant small Trees.- - Small trees, ten chances to one, will come into bearing sooner than the larger ones. * * * The larger the tree the less flbre there will be upon the roots. A tree that has plenty of flbrous roots will live and flourish. while one that lacks such feeders will languish and perhaps die. At least the chances are that it will never be a vigorous fruit bearer. The roots of large trees are always more or less mutilated in taking up, while the small ones do not suffer in this way."-Farm Journal.

Grades.- It is not always possible, especially late in the season, to give the grade ordered. In such cases we send to the amount of value received in the size we have in stock nearest to the one selected.

In Ordering SMALL FRUITS or other small stock, it is an unprofltable plan to include a few large sized trees, as such unduely increases the size of the package, and if to be sent a long distance by express, increases the charges for carriage materially. As many kinds of fruit trees are large and bulky, it is usually best, should a large number be ordered, to have them shipped by freight. The manner in which we pack they will keep in good condition for weeks, in cold weather for months. If ordered to be sent by express, select the lighter grades.

\section{MA N A G M E N T .}

On A r rĩual, trench or "heel" in slanting position, as illustrated and described on front pages. If from the case being broken, or other cause, any trees be found dried or shrivelled, bury root and branch in moist soil, and let remain for a week or ten days to "plump." Never unpack in a frozen condition or in freezing weather.

Planting.--In digging holes place the top soil on one side of the hole and the subsoil on the opposite. The holes should be broader than the roots extend; but not much deeper. Commence flling in with the top soil flnely pulverized; at the same time observing that every root is placed in a natural position and in contact with the soil-by all means carefully guarding against the roots being tangled or matted. The earth should be frequently trodden as the hole is being flled, to firm it. Plant but little if any deeper than the trees stood in the nursery. Dwarf Pears, however, are frequently planted so deep that the junction of the stock with the stem is just beneath the surface, and thus form half standards-often desirable and profltable. Mulch the trees carefully so soon as planted by placing stable manure or other mulching material (manure is best), covering a space somewhat larger than the spread of the roots, to a depth of four to six inches; but put no manure in the holes with the roots. Ground bone or old bones may, however, be used to advantage in the holes when planting.

Pruning.-A greater cause for failure than all others combined is neglect of proper-which is usually insuffleient-pruning at planting. In setting trees scarcely one person in fffty will prune as severely as should be done to insure the best growth and ultimate success, for the reason that to do so causes the trees to look naked and unsightly. Some desire us to prune before shipment. While we would cheerfully do this, we hesitate, as by so doing the spurs thus formed are almost sure to gouge the stems by the jarring and joulting of transportation, multilat:ng the bark, and not only causing the trees to present an unsightly appearance, but producing a veritable injury as well. The subsequent pruning consists cheifly in a judicious thinning of the branches and cutting back the disproportionate ones so as to maintain an open head and a cymmetricial contour. The best season for the operation is the autumn, after the leaves hav; fallen. Pruning may be done, however, at any time during the winter, (except in freezing weather) also just after leaves have expanded in spring. Never use dull tools in pruning.

Culination.-The cultivation should be such as to insure an abundance of light, heat, moisture and manure. It is necessary to keep trees of all kinds in a state of clean and annual cultivation while they are young, in order to secure the best result. All sown erops of grain or grass are very injurious. Orchards should be kept in some crop, such as late potatoes, beans, corn, roots, or any other that grows the entire season, where the whole surface is kept loose and mellow and free from weeds and grass by horse cultivation and the hoe; at least until the trees arrive at bearing age. In plowing and cultivating care should be taken that the roots are not injured or disturbed. When the trees come into bearing, the orchard may be seeded down with clover, allowing the crop to fall upon the ground, and hogs and sheep turned in to eat the falling fruit. This will keep in check the insects that would otherwise ruin the crop in years to follow. 


\section{APPLES.}

Plant 30 feet apart each way-48 trees per acre.

The soil and climate of Monmouth conspire to develop the apple in its greatest perfection and our trees are exceedingly flne in every respect; smooth, straight and handsome. In competition with the world at the great apple exhibition, at the Centennial, the fruit of Monmouth County surpassed all others.

\section{STANDARD VARIETIES.}

First Class. $51 / 2$ to $7 \mathrm{ft}$. - Ea., $20 \mathrm{c}$; doz., $\$ 2.00 ; 100, \$ 12.00$.

Extra, 6 to $8 \mathrm{ft}$., heavy. Our selection of sorts.-Ea., 30c; doz., $\$ 3.50 ; 100, \$ 18.00$.

\section{Thousand rates upon application.}

\section{SUMIER.}

Early Harvest (Yellow Harvest).-Medium, pale yellow, mild and excellent. Early.

Nyack Pippin (Summer Pippin).-Large waxen yellow with blush, excellent. Midsummer.

Red Ast rachau.-Large, crimson, handsome; rather acid but good; ironclad. Very early.

Sweet Bough (Large Early Bough).--Large, pale yellow, sweet, dry: profltable for market. Early.

Tetofaky.-Medium, yellow striped red, subacid, good; early bearer, ironclad, productive. Early.

Titovka (Titus A pple).-Very large, smooth, greenish-yellow striped and splashed with red, subacid; a free grower. One of the best Russians.

Yellow Trausparent (Russian Transparent, Grand Sultan).-Of Russian origin and ironelad hardiness. Medium size; light transparent, lemonyellow, smooth, waxen surface. Very early.

\section{AUTUMN.}

Alexander.--Large, red, beautiful; sub-acid, pleasant; ironclad, valuable. Early.

Duchess of OIdenburg.-Menium, yellow striped with red, good, productive. Mid-autumn.

Euglish Codlin.-Very large, yellow with smoky red cheek, handsome; sub-acid, good, extra for cooking; productive, profitable. Late.

Fall Orange.-Large, yellow, sometime a little dull red, rather acid, prolifle. Mid-autumn.

Fall Pi ppin.-Large, golden-yellow; rich creamy, melting flesh; not productive. Mid-autumn.

Graveustein.-Large, yellow, nearly covered with red; sub-acid, profltable. Mid-autumn.

Maideu's BI ush.--Large, waxen, yellow with carmine cheek; sub-acid, excellent. Early.

Orange Pippiu.-Medium; golden yellow, poor quality; very proliflc. Mid-autumn.

Fed Bietigheimer.--Large, bright rosy red all over; sub-acid. One of the largest and handsomest of all apples.

\section{WINTER.}

Bald wí u. - Large, roundish, dark red, sub-acid, good; productive, profltable, popular. Mid-winter.

Beu Davis (New York Pippin).-Large, nearly all red, poor quality; extra keeper, prolitlc.

Cooper's Market.-Medium, conical, red, smooth; crisp, sub-acid, excellent; productive, reliable. A good keeper.

\section{ADDITIONAL VARIETIES.}

Charlotenthaler,

Diekiuso u?

Early strawberry,

Faueuse (Snow Apple),

Haas,

Hubbardston's Nonesuch

I dia u,
Fallawater (Tulpehocken).-Large, greenish yellow, medium quality; extra keeper, productive.

Gen. Lyon.-Medium, hard and flrm; yellow splashed with red; juicy, pleasant, sub-acid.

Golden Russet.-Medium, roundish; dull russet with a slightly redaish cheek; flesh fine grained, greenish, crisp, juicy and spright'y.

Grimes' Golden.-Medium, rich golden-yel low; crisp, tender, juicy, good; excellent keeper; productive, reliable.

King (of Tompkins Co.)-Large, yellow striped red; tender, excellent; popular, profltable, valuable.

Lawver (Delaware Winter).-Large, bright red; mild sub-acid, productive. an extra good keeper.

Ian n.-Large, deep yellow when ripe; juicy, mild sub-acid; a good grower, abundant bearer, and very hardy. Late.

I eIntosh IR ed.-Medium to large, pale yellow nearly covered with crimson; juicy, excellent.

Newtown Pippin (Albemarle Pippin).Medium, greenish; flne quality and a good keeper. A poor grower and unreliable.

Northern spy.-Large, striped red, rich; good keeper, abundant bearer.

Pennock (Pelican).-Large, deep dull red; flesh coarse, dry, lacking in flavor; superior keeper

Ithode Is land Greening.-Large, yellowish green; tender, rich, productive. Mid-winter.

IRoxbury IR uset (Boston Russet).--Largest of all the russets; sub-acid, extra quality; productive. profltable. Mid-winter.

Smith's Cider (Salisbury).-Medium, greenish white, striped red, iair flavor; proliflc, reliable. Most popular winter apple throughout N. J., and $\mathrm{Pa}$.

Talman's sweet.-Medium, light yellow: rich, excellent; productive and profitable.

Walbridge.-Medium, pale yellow streaked red; crisp, tender, sub-acid; very hardy. Late.

wealthy.-Medium, roundish, brilliant light red, tender, Juicy, sub-acid, extra. A free grower, very productive and of iron-clad hardiness.

Willow Twig.-Large, slightly conical, greenish-yellow striped with dull red; sub-acid and of inferior quality. A long keeper. Proftable.

Winesap.-Medium, dark red; crisp, extra; productive, desirable, profltable. Late.

York Imperial (Johnson's Fine Winter).Medium to large, white heavily shaded with dark crimson, firm, crisp, juicy, sub-acid.

First class, ea., 25c; doz., $\$ 2.50 ; 100 ; \$ 15.00$.

\begin{tabular}{l|l} 
Keswick Codliu, & Ibidge Pippin, \\
Lankford, & Salome, \\
Monmouth Pippin, & Smokehouse, \\
Nero, & Stump, \\
Pewaukee, & Suton's Beauty, \\
Prinate, & Summer Hagloe.
\end{tabular}




\section{NEW VARIETIES.}

(1 yr. by mail 3c. each additional.)

CA L LUGH.-In this are combined the valuable qualities desired by everybody, viz.: a long keep-

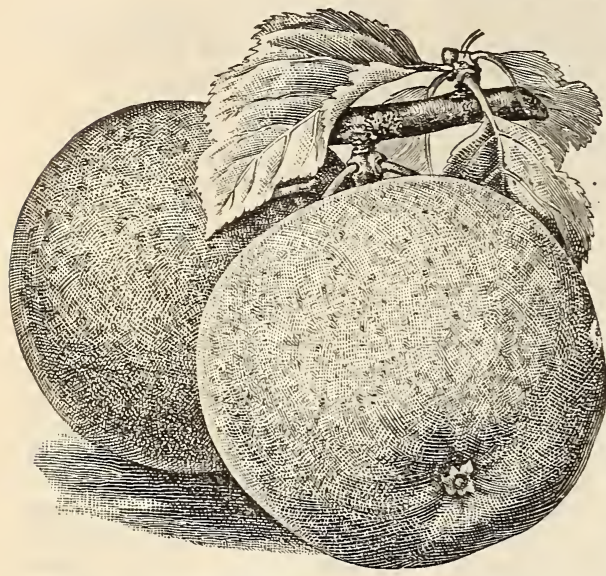
ing, handsome, sweet apple; and we unqualifledly state that for great beauty of fruit, long keeping and handsome growth of tree it is absolutely without a rival among apples, The fruit is of medium size, ovate and almost as smooth and uniform in size and shape as though made of wax from a mould. Color bright lemon-yellow, covered with lively crimson next the sun-as smooth and beautiful as is possible to imagine-hangs on the tree until freezing weather, if permitted.and will keep in good condition without any special care whatever until June. In quality it is of the best, being sweet, mild, creamy and pleasant. The tree is a most vigorous and beautiful grower with stems as straight as bamboo poles, smooth, with a heavy growth of large foliage; also an enormous, annual bearer. The Carlough is a chance seedling that originated in Rockland Co., New York, on a farm now owned by Joseph Carlough, in whose honor the variety is named. On learning of its wonderful keeping properties, growth, productiveness and bearing every year, we arranged for its introduction. Mr Carlough wrote us on April 5th 1885, "I have looked after the fruit for the last flve years. Its good qualities are late keeping and bearing every jear. It hangs on the tree until November and will keep untîl June or July." Ist class, ea., 50c; doz., \$5.00; 100, \$30.00. 2 yrs., ea., $40 \mathrm{c}$; doz., $\$ 4.00 ; 100, \$ 25.00$. $1 \mathrm{yr}$., ea., 30c; doz., $\$ 3.00$.

GA NO.-From Missouri. Slightly conical, full

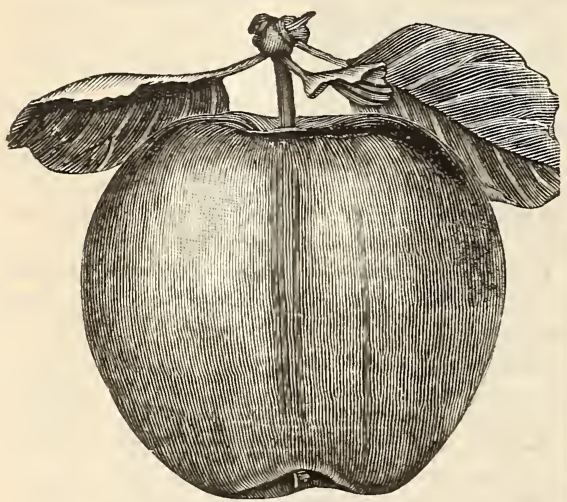

JA COR'S SWEE'T.-A large and exceedingly

GANo.

medium size, of a clear deep red, mohngany next the sun, russet about the stem; flesh pale yellow, flne grained, tender, pleasant, mild sub-acid. though not highly flavored. Skin very tough. Tree healthy, vigorous and hardy, a rapid grower and an early, annual, and proliflc bearer, A superior keeper. 1st cl., ea., 35c; doz., $\$ 3.50 ; 100, \$ 20.00 .2$ yrs., ea., 30c; doz., $\$ 3.00 ; 100, \$ 15.00$. 1 yr., ea., 25c; doz., $\$ 2.50$.

A ugust. - A seedling of Wealthy, strong spreading grower; medium, yellow striped with light red; good. Summer. Excelsior.-From Wealthy seed; strong upright grower; medium tolarge, pale yellow striped with bright red; very good. Autumn. October.-From seed of a crab; very strong grower and profuse annual bearer; large, red; acid, flne for cookIng. The three are seedlings raised by Peter M. Gideon of Minnesota. Price of either variety. 1st el., ea., 35c; doz., \$3.50. 1 yr., ea., 25c; doz., \$2.50.

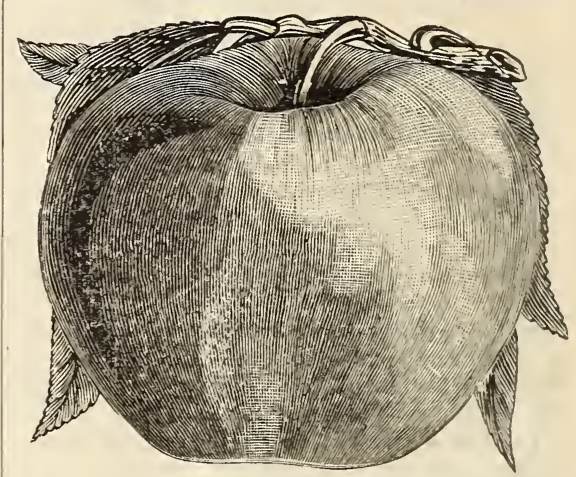

JACOB'S SWEET.

showy fruit. Clear, rich yellow, deeply shaded with brilliant carmine; flesh crisp, flne grained and of best quality. Also a remarkably good keeper, remaining in good condition until June. Tree a strong, vigorous grower, heavy yielder, and an annual bearer. Originated near Boston, Mass., and unites great beauty, superior keeping properties and high quality. 1st cl., ea., 35c; doz., $\$ 3.50 ; 100, \$ 20.00$. 1 yr., ea., $25 \mathrm{c}$; doz., \$2.50.

Fed Cider.-Except in color, this strongly resembles Smith's Cider. Large, handsome, brilliant red, highly colored; tender, mild and pleasant; moderate grower and a most abundant bearer. Winter. 1st cl., ea., 35c.; doz., \$3.50. 1 yr. ea., 25c.; doz.,\$2.50.

Whinery's Late Fed (Whinery's Winter).A handsome deep red apple resembling Ben. Davis, but of much better quality. From northern Ohio where it is claimed to be the longest keeping and most profitable apple. Winter. 1st cl. ea., 35c. ; doz., \$3.50; 100, \$20.00. $1 \mathrm{yr}$. ea.. $25 \mathrm{c}$; doz., \$2.50. 


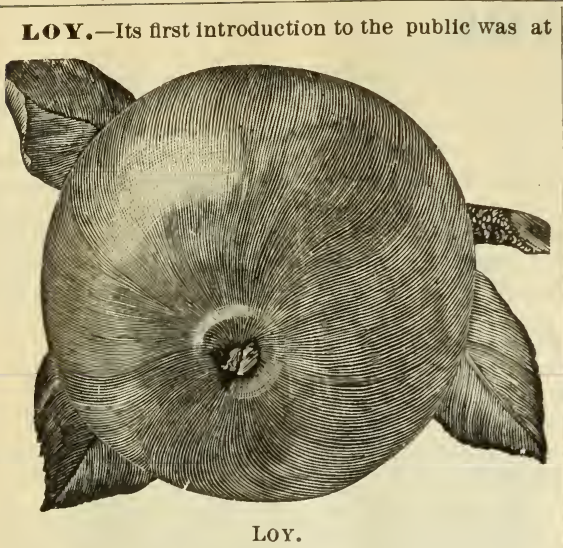

the New Orleans Exhibition, where it was awarded the prize for the Best New Apple. From southern Missouri. The fruit is as large as the Ben Davis; resembles the Willow Twig in form and color; core small; stem short; quality rich and exceedingly high; an extra long keeper. Tree a good grower, hardy; an early and annual bearer. Winter. 1st cl., ea., $40 \mathrm{c}$; doz., $\$ 4.00 ; 100, \$ 25.00 .1$ yr., ea., 30c; doz., $\$ 3.50$.

GLOWING COA L.-Remarkable in three important respects, viz., for its large size, great beauty, and superb quality. Fruit enormous in size, and of extra fine quality, ripening early in September. One half of the apple is a bright shining red, while the other half is intense scarlet, and, as they hang on the tree, the enormous fruit may be seen for a long distance, like glowing coals. Tree is a flne grower, a heavy and early bearer. This is going to become the flnest of all apples for market, its great beauty as well as its unexcelled quality making it a quick seller. Autumn. 1st cl. ea., 75c.; doz., \$r.50. $1 \mathrm{yr}$. ea., 50c. ; doz., $\$ 5.00$.

Marshall's Seedling (Red Bellflower).-It has the deep brilliant red of the Red June, with its sprightly acid flavor, but of the exact shape of a good sized Yellow Bellflower, although the tree of more upright growth, and a regular and heav'y bearer. Winter. 1st cl., ea., 30c; doz., \$3.00.

\section{CRAB APPLES.}

Prices: First class, each, 20c; doz., \$2.00.

Hyslop.-Large, roundish, deep red with blue bloom; very pretty; flesh yellowish; excellent for cider and jelly, popular. Late.

Lady Eloin.-Similar to Lady apple in size and appearance, tender, juicy and good; an upright vigorous grower, early and prolittc bearer. September and October.

Paul's Imperial. - A hybrid between Red Astrachan apple and Red Siberian crab. Fruit roundish yellow, almost covered with bright red; yellowish, flrm, tender and good.

\section{CRANBERRIES.}

By mall postpaid at 50 c. per $100 ; \$ 3.00$ per 1000 . By express, 50c. per $100: \$ 2.50$ per 1000 . Lots of 5000 and upwards at special rates.

Large Cherry. - There are many varieties called cherry, but the one offered is the largest and best of them all. Large, round, bright red and a good keeper, vine vigorous, prolific. Rather late.

\section{Searlet Crauberrv (Cranberry Winter).-}

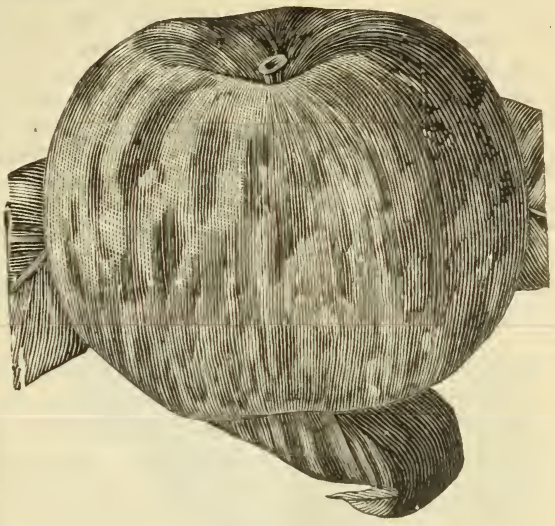

SCARLET CRANBLRRY OR ROBINETT.

Originated in Virginia. Remarkable for its longkeeping properties, remaining in excellent condition for a whole year. Large; light shaded to deep red and striped with mahogany: sub-acid, rich and A good grower and productive. Especially for the South. Winter. 1st el., ea., 35c edium size and high quality, the most brilliant red , and of perfect form. The fruit is almost The tree is a strong grower and an early and abunExceedingly valuable. Early autumn. st cl., 75c.; doz., \$7.50. 1 yr. ea., 50c.: doz., $\$ 5.00$ vanhoe.-A valuable new apple from Virginie of flne appearance and long keeping properties. The Fruit medium to large; light golden hen ripe; of excellent quality-crisp, Juicy. sprightly. When green it much resembles Albemarle Pippin, of which it may be a seedling. It hangs on the tree till late, and is an excellent keeper. 1st $\mathrm{cl}$. ea., 35c.; doz., \$3.50. 1 yr. 25c.; doz., \$2.50.

Fed Siberian.-Small, yellow and scarlet, handsome; tree erect; full grower and early bearer.

Transcendant.-Large, yellow, mostly covered with red: tree very vigorous and productive. Popular and desirable. September and October.

Whitney's No. 20.--Large, striped, almost red, flesh yellowish white, very juicy, sub-acid, excellent; very valuable. August.

Yellow Siberian (Golden Beauty).-Simllar to Red Siberian except in fruit, which is of golden yellow. September.

Hell.-Well-known and extensively grown. Of good size, bell-shaped, dark red, although variable in form and color, vines proliflc. A good keeper. Ripens earlier than Cherry. 


\section{PEARS.}

Plant Standards 20 feet apart each way-108 trees per acre; Dwarfs 7 to 10 feet apart each way.

Pears should be $g$ thered from the trees and ripened in the house; some are worthless if left to ripen on the trees and all are better in quality if properly ripened indoors. Summer pears should be gathered at least ten days before they would ripen, and autumn varieties two weeks. Winter pears should be permitted to hang upon the trees until late-until the leaves have fallen if they will remain that long-then gathered and treated the same as winter apples. Dwarf Pears are those budded upon Quince stocks; and although valuable for those who have but limited space for planting, yet are by no means so reliable or productive as standard trees. If planted deep they will form what is known as "half standards," which are usually productive and profltable. Dwarf Pears will not prove.fruitful unless given high and careful culture and pruned annually.

\section{GENERAL LIST.}

Standard.-First Class, 5 to 6 ft., ea., $35 \mathrm{c}$; doz., $\$ 3.50 ; 100, \$ 20.00$.

$66 \quad$ Two years, 3 to $5 \mathrm{ft}$., ea., $25 \mathrm{c}$; doz., $\$ 2.50 ; 100, \$ 15.00$.

Dwarf,-First Class, ea., 25c; doz., $\$ 2.50 ; 100, \$ 12.00$.

Those with the letter $D$ affixed to the name we can supply both as Dwarfs and Standards. They are showy and are those that succeed best on the Quince.

Bartlett. $D$-Large; clear yellow; juicy, buttery, excellent; thrifty, young, heavy and regular bearer; very reliable and popular. Late summer.

Beurre d'Anjou. D-Large; russety-yellow with red cheek ; buttery, melting, superb; vigorous, productive, reliable, popular. Late autumn.

Bufum. $D$-Nedium, oblong-orate; deep yellow, shaded red; juicy, buttery, good. Late autumn.

Clapp's Favorite. $D$-Large: delicious; good grower, productive. Ripens in advance of Bartlett, rots unless picked early. Midsummer.

Doyenne Boussock. $D$-Large; yellow, handsome; buttery, good: productive. Early autumn.

Duchesse d'Angouleme. D-Extremely large; dull yellow; juicy, fair to good; vigorous; best as a dwarf. Midautumn.

Flemish Beauty. $D$-Large; pale yellow, much russeted; rich, melting; vigorous, productive; very hardy, not generaily reliable. Early autumn.

Howell. $D$-Rather large; obtuse pyriform; pale yellow with red cheek; quality good to very good; reliable, popular, profitable. Late autumn.

Kieffer.-From seed of the Chinese Sand pear

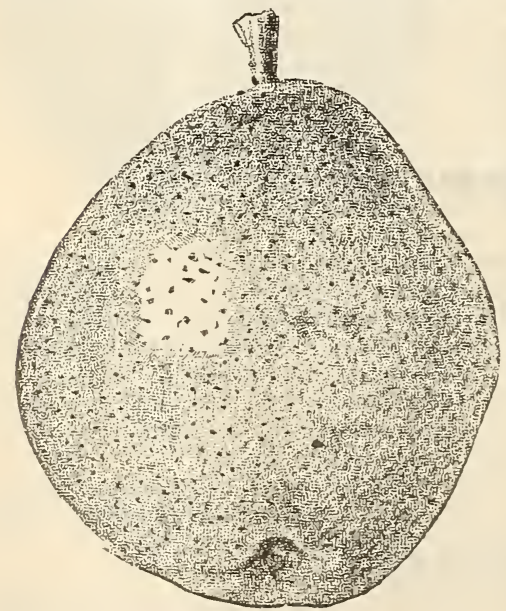

crossed with one of our cultivated varieties. Large; showy, rich, golden yellow dotted thickly, shaded red; quality fair to good, juicy, flrm; strong, vigorous grower, early bearer and wonderfully productive Very profltable. Midautumn.
Lawrence.-Medium; light vellow; buttery, sugary, excellent; reliable, productive, proftable; the best winter pear. Early winter.

Le Conte.-Resembles somewhat the Kieffer and of similar parentag e. Large; bells h a p e d, greenish y e $110 \mathrm{w}$, $\mathrm{smoct} \mathrm{h}$, waxen skin, handsom e; flesh white juicy,superior quality. A rampant grower,ear$1 y$, annua 1 and prolifle bearer. Excee dingly popular at the South where it has been extensively plant.

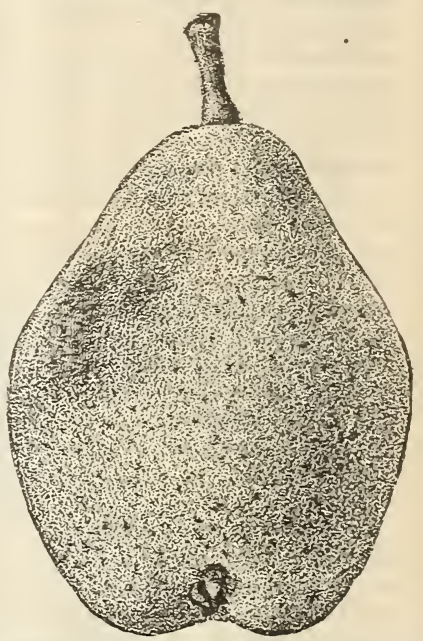
ed with marvelously profitable results. Extra sized flne bearing trees of this Pear will be supplied at 50c ea.; $\$ 5.00$ per doz.; $\$ 3000$ per 100 .

Louise Bonne de Jersey. $D$-Large, greenish brown; juicy, melting, rich : not rellable: succeeds well on the quince. Late.

Ianning's Elizabeth. - Small; yellow with bright red cheek; very sweet and good; moderate grower, heavy annual bearer, free from blight, very early and desirable, proflable. Early summer.

Seckel.--Small; yellowish russet with cinnamon red cheek; rich, juicy, melting, exquisite; of slow growth, productive; profitable. Early autumn.

Sheldon.-Medium to large; yellowish russet; melting, very juicy, delicious; desirable. Late autumn.

Tyson. $D$-Medium size; bright yellow with reddis b brown cheek ; melting, sweet, buttery, juicy; vigorous grower. Early summer.

Vicar of Winkfield. $D$-Very large; yellowish green ; juicy, usually of poor quality ; good grow$(30)$ 


\section{NEW VARIETIES.}

IDA HO. - This valuable new pear has met with

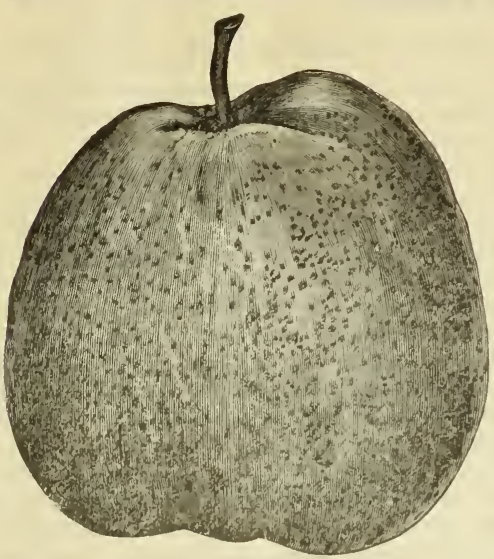

much favor from fruit-growers, and deservedly so. It is a seedling of a large, red-cheeked pear, name unknown, raised by Mrs. Mulkey of Lewiston, Idaho, who planted the seed about twenty years ago. The tree fruited the fourth year from the seed, and has borne annually ever since,seeming to be entirely har$d y$. As its birth place lies in or near the latitude of Quebec, it has survived winters when the thermometer ranged from 15 to 30 degrees below zero. The trees are upright and vigorous in habit, having dark foliage. The fruit is evenly distributed over the tree, sometimes in clusters. The combined weight of a cluster of four was $811 / 2 \mathrm{oz}$., the largest weighing 23 oz. It is of the largest size; color greenish-yellow with russety spots; form, roundish-obovate; flesh, melting, juicy, entirely free from gritty texture: flavor good, rich, sprightly vinous; core exceedingly small and without seeds. Season, September and October. 4 to $6 \mathrm{ft}$., ea., $\$ 1.00$; doz., $\$ 1$ v.00. Mailing size, postpaid, ea., 50c; doz., \$5.00.

JAPAN GOLDEN IBUSSE'T.-The original tree was found accidently in an importation of Japanese Persimmon trees and has since proved a remarkable fruit in many ways. It is said by the introducer to be an exceedingly early bearer and bears enormously every year, having no off years, the fruit hanging in great masses or clusters. The follage is tough and leathery enabling it to endure great heat and drought, without injury. The fruit is handsome, of a flat or apple shape, very uniform, of good sizeeight or ten inches around-and becomes of a handsome golden-russet color. Ripens in September. 3 to $4 \mathrm{ft}$., ea., $\$ 1.00$. Malling size, postpaid, at same price.

Smith's Hybrid.-In brief this may be described as an improved LeConte. The fruit is large, and of better quality than that fine sort, being rich, juicy, melting and luscious, with sinooth creamy texture, free of granulations. The fruit is exceedingly smooth and handsome, uniformly very large and perfect, similar in color and form to the LeConte, and ripens with it. Tree equals the Le Conte in luxuriant growth and rich abundant follage and is very proliflc. Standard, 1st cl., ea., 50c; doz., $\$ 5.00$; 100, $\$ 30.00$. Mailing size, postpaid, ea., 30c; doz., $\$ 3.00$.
LA WSON or COML'T. - This remarkable

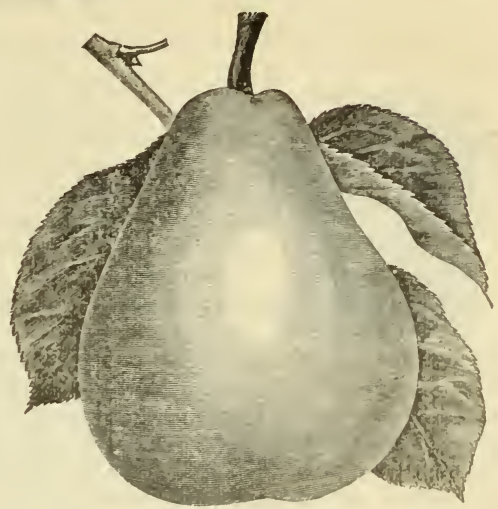

summer pear is not only the most beautiful in appearance, but the largest early pear yet produced. It is large for an early pear, and cannot be surjussed in point of color, which is a most beautiful crimson on a bright yellow ground. Flesh crisp, juicy and pleasant, but not of high quality, and should be used before getting overripe. Ripens in central New York from middle of July to first of August, and possesses superior keeping and shipping qualities. There are few summer pears that are as profltable as the Lawson and, when properly grown, its size, beauty and earliness cause it to meet with a ready sale. Standard. 1st cl., ea., 50c; doz., \$5.00; $100 \$ 30.00$. Malling size, postpaid, ea., 30c; doz., \$3.00. Dwarf, 1st cl., ea., 40c; doz., $\$ 4.00 ; 100, \$ 25.00$.

WVILD E R. - Though small to medium in size, this is as large as any of its season, except Lawson, and ripens in western New York about August 1st. It is pyriform in shape; smooth and of a pale yellow color with deep red cheek and numerous red dots, very attractive; flesh fine-grained, tender, very good, with rich, sub-acid, sprightly flavor. It does not rot at the core-an especially desirable merit in an early pear-and bears shipment well. Standard, $1 \mathrm{st} \mathrm{cl}$., ea., 75c; doz., \$7.50. Malling size, postpaid, ea., 50c; doz., \$5.00. Dwarf, 1st cl., ea., 60c; doz., $\$ 6.00$.

H ESSEITIA N KA.-A Russian variety of extreme hardiness and of excellent quality, exceedingly valuable from the fact that it extends the possibilities of satisfactory pear-growing at least 100 miles further northward. In Vermont it has passed through several winters when the thermometer has reached $40^{\circ}$ below zero for many continuous nights. The fruit is medium in size, perfect pear-shaped, and nearly or quite seedless; flesh tender, Juicy, mildly sub-acid, almost buttery, and very satisfactory for dessert use. The tree is a rapid, upright grower, with bright green follage always free from rust or mildew. Season September,

Dr. Hoskins, of Vermont, says: "I have been trying for twenty-three years everything called hardy among the older varieties of European and American pears (including all the Maine and western Vermont seedlings), with very little success; losing all of them in the two severe winters which left the Bessemianka unscathed." Standard, 1st cl., ea., 50c; duz., $\$ 5.00$. 


\section{PEACHES.}

Plant 18 feet apart each way-134 trees per acre. On sandy land plant 15 feet apart each way.

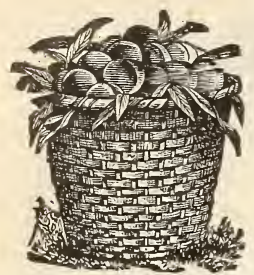

As both the soil and climate of New Jersey conspire to develop the peach in its greatest perfection, we grow them in vast numbers and are enabled to supply trees at low prices; surpassed by none and equalled by few.

The best soil for peaches is a sandy loam, not highly charged with vegetable matter, and trees should not be'planted upon soil whtre the water stands near or upon the surface. Spring is to be preferred for planting, although it may be done quite successtully in autumn with proper care. If the soll be light, set the trees flfteen feet apart each way, requiring 193 trees to the acre. Plant no deeper than the trees stood in the nursery and make the soil very firm. It is important that the young tree should be properly pruned at the time of planting. All side branches should be cut back to within a few inches of the main stem, the latter being severed at about twothirds the distance from the ground. Small trees should be pruned to a whip, cutting back the stem nearly one-half the way to the ground. The after culture is simple, being merely to keep the surface always mellow and free of weeds. For the first two years after planting, hoed crops may be planted between the trees with adyantage, after which time they require the entire strength of the soil. Grain crops of all kinds are injurious, and peaches seldom succeed in sod or grass. We have found nothing so admirable and rapid as the Acme Harrow for cultivating the peach orchard and keeping the surface mellow. Unleached wood ashes and pure ground bone are the proper fertilizers for the peach, and are best applied broadcast in spring and harrowed in. If wood ashes cannot be obtained, muriate of potash may be used in its place, with excellent results. The enemies with which the peach culturist has to contend are the borer and the yellows. The former is easily overcome by making a thorough examination of the trees regularlv every spring and cutting out with a sharp knife the grubs, whose presence may be readily detected by the gum formed from the exuding sap.

All varieties are freestone except those noted otherwise. Those in CAPITALS are of great value. The letter $(N)$ succeeding the name signifies that the variety is especially valuable for the North on account of hardiness; those with $(\mathbf{S})$ especially for the South.

\section{STANDARD VARIETIES.}

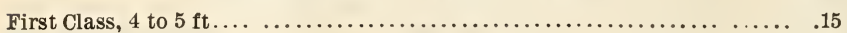

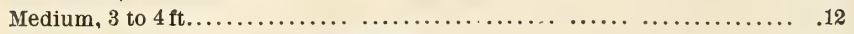

Second Class, 2 to $3 \mathrm{ft}$. , and June Budded....................... 10

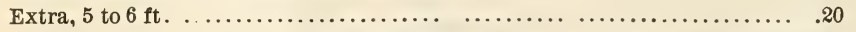

$\begin{array}{rrr}\text { Doz. } & 100 & 1000 \\ \$ 1.50 & \$ 6.00 & \$ 50.00 \\ 1.25 & 5.00 & 40.00 \\ 1.00 & 4.00 & 30.00 \\ 2.00 & 8.00 & \end{array}$

(June-budded trees by mail $3 c$. each additional.)

Amsden's June and Alexander's Early

(N.S.)-Absolutely identical to all appearance of fruit and tree. Fair size and good quality; nearly all red, flesh greenish - white, very juicy; clings partially to the pit. Middle of July.

Barnard (Yellow Alberge, Yellow Rareripe.) N. S.-Large: yellow shaded with dark brownish red; flesh yellow, juicy, rich, excellent. Hardy and a heavy bearer. Early.

Beer's Late.-A seedling of Crawford's Late, with which it ripens and differs only in being smaller and a more regular and abundant bearer.

B EER'S SMOCK (Sməck Free).-Medium to large; yellow with a dull red cheek; flesh yellow and of poor quality. A regular and enormously productive bearer. Very late.

CHA I RS' CHOICE.-Of largest size; deep yellow with red cheek; flesh very flrm, five days earlier than Smock; a strong grower and heavy bearer.

CRA WFORD'S EARLY (Early Melocoton) N.-Very large;yellow with red cheek, handsome: flesh yellow, excellent quality; vigorous and productive. Popular. Middle of August.

CRA W FOR D'S LATE (Melocoton). - In appearance resembles C. Early, but larger and ripens from two to three weeks later; flesh yellow, reddish at the pit, juicy and rich. One of the best.

Early Rivers (Silver Twig).-Medium to large; pale yellow with pink cheek; delicious, rich. Last of July.
Elberta ( $S$ ). - A seedling of Chinese Cling but entirely free. Large; yellow with red cheek, juicy and of high quality; flesh yellow and melting, A very valuable new sort. September.

FORD'S LATE.-Vigorous grower and very productive. Fruit very large; white and beautiful; flesh quite free, white, solid, and flne in texture; fine quality. Ripens in October, after the Smock.

Foster.-Similar to Crawford's Early, but a few days earlier, larger and of better quality.

GLOBE. - An Improvement upon Crowford's Late. Vigorous and productive. Fruit large, globular; of a rich golden yellow with red blush; flesh yellow, firm, juicy. Middle of September.

Hale's Early (N. S.)-Medium; white, with red cheek, juicy, fair quality: half cling. Productive, but rots badly unless on light soil. Last of Julv,

Hance's Golden.-Almost rounç, large; yellow with rich crimson cheek; of highest quality. A sure and heavy cropper, ripening with Crawford's Early.

Heath Cling (Late White Heath, White English, Eliza Thomas, White Globe, etc.) S.-Extra large, white with blush cheek; flesh clear white, of very fine quality and one of the best of the clingstone varieties. Ripens late-a superior keeper.

Hill's Chili (Jenny Lind) N.-Large; dull yellow shaded with dark red, very downy; good flavor. Very hardy and proliflc. Last of September. 
Hyne's Surprise.-White with red cheek, resembling somewhat Hale's Early, but less inclined to rot. Ripens a few days after Early Rivers.

Jacques, Rareripe $(\boldsymbol{N})$.-Large, roundish; dark yellow and dull red; flesh yellow, juicy, slightly acid. Middle of September.

KEYPOK T WHITE.-Large; pure white, and white at the stone. Hardp, strong grower, and very proliflc. Freer from mildew and cracking than most white freestone solts, and one of the best and most reliable of this class.

Large Early York (Honest John).-Medium; white dotted with red, with red cheek, flesh nearly white, juicy, rich, and of high quality; not a reliable cropper in most sections. Last of August.

Levs's Late (Henrietta) S.- Specially valuable for its extreme lateness, remarkable beauty and large size; yellow with crimson cheek; flesh yellow. firm, juicy. good. Its keeping qualities are remalkable. Cling.

IMUN'TAIN ROSE.-One of the best and most reliable early peaches. Large; white suffused with carmine; flesh white, melting, abounding with rich, sweet juice. Productive. Early August.

Vuir.--Large to very large; yellow; a the shipper and valuable for canning and drying. A California seedling.

Oldmixon Cline (S)-Large; creany-white with rec cheek, flesh white, rich and juicy. One of the best elings. Middle of September.

OLDMIXON FitEL. - Uniformly large; creamy white partially covered with bright red: flesh white, red at the pit, tender, rich and juiev. One of the best and nost reliable. Popnlar everywhere. Last of August.

IR EED'S EAIE LY GOKDEN (Reed's Golden Yellow) S.-An improvement on Craw ford's Early with which it ripens, but it is much larger and handsomer, and a very reliable and heavy bearer.

\section{NEW VARIETIES}

(June budded trees by mail at $3 \mathrm{c}$ each alditional).

LOVE'T'S WHI'E. -What Wonderful is among yellow peaches, Lovett's White is among white varieties. Fine white peaches are always in demand and are very desirable, especially late in the season. when they invariably command good prices. In Lovelt's white may be found every quality demanded in the ideal white peach, with the additional merit of an ironclad tree. It has the size and all the merits of the old Late White Heath or Heath Cling, with the additional one of being a perfect freestone, ripens with it, and is handsomer, hardier, of better quality and a more abundant and regular bearer. It has been thoroughly tested both at the North and South, and is a sure and abundant bearer-yielding ansually in Mass. and Conn., in orchards where almost all other varieties fall, We are confldent it is the hardiest purely white peach yet produced. Season very late; color pure white; very large; splendid form, with indistinct suture; does not erack and is exceptionally free from spots or mildew. It is a long keeper; the flesh being flrm, sweet and excellent, and parts from the pit perfectly. It seems to us

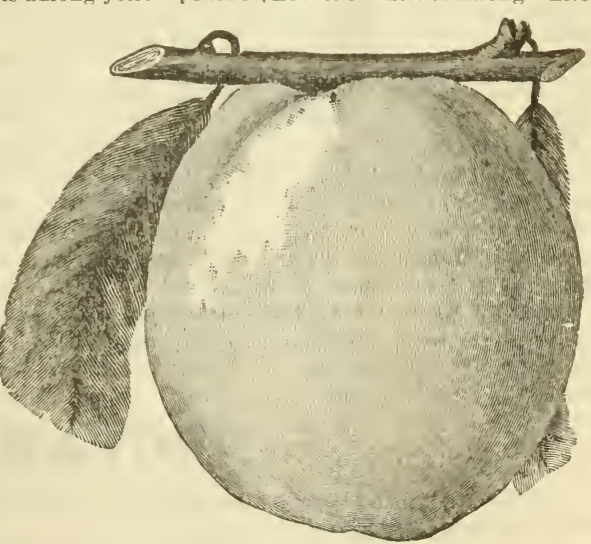

LOVETT'S WHITE. that this surely fulflls all that is needed in the ideal late white peach, and the tree is an excellent grower, exceedingly hardy and wonderfully proliflc. Its fruiting each year fully confirms all that we have said of it in the past and there is no need for seeking further for a peach of its season and color. 1st c., ea., 25c; doz., $\$ 2.50 ; 100, \$ 15.00$. Medium, ta., 20c; d'z., $\$ 2.00 ; 100, \$ 12.00$. J. B., ea., 15c; doz., $\$ 1.50 ; 100, \$ 10.00$. 


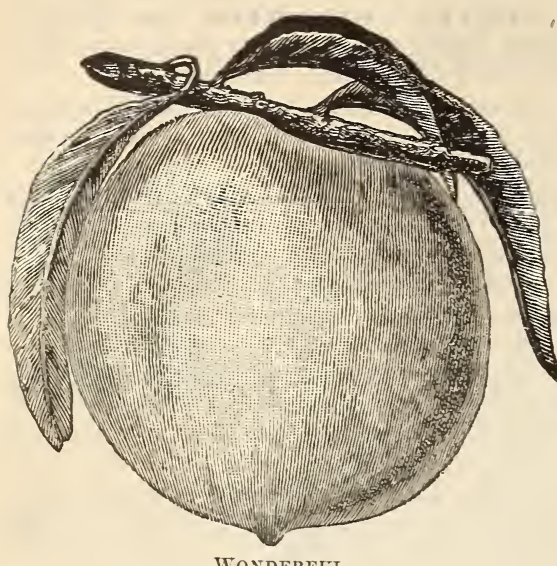

WONDERFLL.

WONDER F UL. - Undoubtedly the finest late yellow peach yet introduced. It has proved itself to be as large and beautiful as Crawford's Late or Globe, as late as the Smock or later, a remarkable grower, and a reliable and heavy bearer. It is of New cersey origin-the State that has produced so many valuable peaches. The fruit is very large, the best specimens measuring eleven inches in circumference and weighing as many ounces; smooth, almost globular, with a faint suture and slightly pointed apex, very regular and uniform in both size and shape, even upon overloaded trees; of the richest golden yellow, largely overspread with vivid carmine, with marblings of crimson-beautiful in the extreme: flesh yellow, rich, high-flavored and delicious, exceedingly firm, parts from the stone perfectly and dry, and is bright red around the pit. The tree is of strong, vigoro's growth, a regular annual bearer, and so prolific as to require the limbs to be braced to sustain the weight of fruit. Its season is late to very late, ripening in central New Jersey the second week in October and keeping in good condition as long as three weeks after gathered. 1st c., ea., 20 c; doz., $\$ 2.00 ; 100, \$ 10.00$. Medium, ea., 15c; doz., $\$ 1.50 ; 100, \$ 8.00$. J. B., ea., 10c; doz., $\$ 1.00 ; 100, \$ 6.00$.

B U R K E. $-A$ seedling of the Chinese Cling and the largest of that class. It is described as being very large. roundish-oblong; pale creamy white slightly shaded with red; flesh white, juicy, of flne flavor; clingstone. Ripens at its home in Louisiana in July. Price same as Wonderful.

GOOD. - A magniflcent white peach of large size from Penn. Flesh white, juicy, sweet, melting, and of delicious flavor. Exceedingly handsome and attractive. A very reliable and choice sort, being hardy and yielding when many others fail. It is often blush or light crimson next the sun. Although a freestone the pit is large and deeply corrugated. Its large size, great beauty and excellence, and especially its uniform productiveness by virtue of its hardiness of blossom and tree, render it a most valuable peach. Last of September. Price same as Lovett's White.

COOLEY'S MA MIOTH. - Originated in Indiana where it has attracted considerable attention by reason of its large size and beauty, and has been awarded first premium. It is very large, of a beautiful rich yellow, dotted and splashed with red and white, and with luscious, melting flesh; very valuable. Price same as Wonderful.

KA LOOLA. - A seedling of the Chinese Cling, of which the originato" says; "It is the best clear seed peach that I have ever seen. I have fruited it for several seasons. It is large, oblong; creamywhite with slight blush on the sunny side; very tender and juicy. Price same as Wonderful.

NOR II N D'S CHOICE.-Also from Louisiana, ripening there in September, and claimed to be the hest peach of that season. Price same as Woíderful.
HUGHES, IXL.-From Louisiana and ripens there in October, making it a very late peach. It is said to be undoubtedly the largest and best peach of that season yet produced. Large and round with suture; a beautiful yellow; tender and juicy, and in flavor unsurpassed; cling; a flne shipper and extra for canning. Price same as Wonderful.

LEMON FREE.-The introducer says of it: "The name is very appropriate, as it is of almost lemon shape, being longer than broad, pointed at the apex, color a pale lemon yellow when ripe. It is of large size, the flnest specimens measuring over twelve inches in circumference: of excellent quality, ripens after Late Crawford; immensely productive, and will undoubtedly become one of the leading orchard varieties." Price same as Wonderful.

HUSTED'S EARLY. - A seedling from Smock, season with Alexander, better quality, larger size, with less rot, bears transportation well. Blooms very late; productive. Price same as $\mathbf{W}$ onderful.

Chinese Blood (Japan Blood). -This has not fulflled the claims made for it by its introducers. We find it small and without special merit, its one good feature being its good quality. Ripens with Oldmixon Free. Price same as Wonderful.

Williamson's Choice.-A new peach of New Jersey origin, scarcely as large as Crawford but more beautiful and a better bearer. Flesh yellow, firm, and of excellent, high flavor. A proflable sort for market as it sells readily at sight by reason of its great beauty, and the tree is remarkable for its abundant, regular, annual bearing. Price same as Wonderful.

\section{NECTARINES.}

This fruit is really a smooth skinned peach. Its greatest eneny is the curculio, Plant same distance. and cultivate same as peaches.

First Class, ea., 25c; doz, $\$ 2.50 ; 100, \$ 12.00$.

Early Newingto n.-Large, pale green, juicy, rich, excellent. Clingstone. Early autumn.

Early Violet(Violet Hative).-Medium, yellowish-green, high flavored; freestone. Late summer.

Hardwick.-Large, pale green, juicy, rich: an old and popu ar sort. Late summer.

stanwick.-Large, white with red cheek; free; (34) 


\title{
PLUMS.
}

Plant 16 to 18 feet apart each way.

Grown on plum stocks. These varieties of the European plum should be given heavy soil. The curculio must be baffled by jarring or repelled by smudging, to save the crop; and the "black knot" removed from all trees as soon as it makes its appearance, and burned.

Fi rst-class -5 to $7 \mathrm{ft}$., ea., 50c; doz., $\$ 5.00 ; 100, \$ 25.00$.

Bradsha w(Black Imperial). - Very large; dark | black with blue bloom; flesh greenish-yellow, Julcy, violet red; juicy, vigorous, productive. Early.

Coe's Colden Drop.-Large: handsome, yel- er, and an early and abundant bearer.

low; flrm, rich, sweet; popular. Late.

General Hand.--Very large; yellow. handsome; only fair quality; productive. Medium.

German Prune.-Medium, oval: purple, juicy, rich, sweet: productive, popular. Midseason.

Imperial Gage (Prince's Imperial).-Large, oval; greenish; juicy, rich, excellent; desirable.

Lombard.-Mediun, oval; violet-red; flesh yellow, juicy, sugary;vigorous, a great bearer. Medium.

Mon roe Eqa.-Medium, oval: greenish-yellow; sweet, good; vigorous, productive. Early.

Noore's Aretic. - A hardy plum from Maine where, exposed to Arctic cold, it has for years borne enormous crops. Claimed to be the hardiest plum knowu. Medium in size, roundish oval; purplish-

Quнckenboss. - Large; deep purple; flesh coarse, juicy, sprightly. Midseason.

Kei ue Claude (de Baveu).--Very large: greenish shaded red; flne flavor; very proliflc. Late.

Fichland. - Medium; greenish-purple: firm sweet, excellent; productive and reliable. Early.

shipper' Pride.-Large, round; purple; very flrm, excellent quality. A strnng, upright grower and regular bearer. Very productive.

sh ropshire Damson.-An improvement upon and double the size of the common Damson.

Washington (Balmer'y).-Very large; yellowish green; juicy, sweet, good; rots badly. Early.

Yellow Egg (Magnum Bonum).-Large, oval; vellow; juicy, rich; vigorous, productive. Early.

\section{AMERICAN VARIETIES.}

June budded trees by mail, 3c. each additional.

Price, 1 st cl., ea., 20c; doz.. \$2.00; 100, \$12.00. June budded, ea., $12 c$;oz.,

$\$ 1.25 ; 100, \$ 8.00$, unless otherwise noted.

Deep Creek.--Medium to large; deep red; very small stone; sweet and good; a very early bearer (often at two years old) and proliflc. 1st cl., ea., 25c; doz., \$2.50.

De Soto.-Medium; bright red; swest, rich, of fine quality. Extremely hardy and productive. 1st cl., ea., 25c; doz., \$2.50.

Lone Star.-Nearly as large as Wild Goose; of similar quality; pale red, and very productive. Very early (ripening with lite cherries). Ea., 25c; doz., $\$ 2.50$.

Forest Garde $\mathbf{~} .-$ Ripens a little in advance of De Soto $\mathrm{w}$ hich it closely resembles and is of the same ironclad hardiness,

Wild Goose (True). - Large; rich,crimson, beautiful; flesh soft, melting, rich, delicious, with a full fruity flavor; tree a strong grower and very proliflc. A great many spurious kinds are being sold for Wild

Goose, but the true sort is a large plum, and ripens early in July. Succeeds best on light land.

Kobi nson, - Rather small, slightly oblong; clear bright red, and of superior quality, being sweet and juicy. Valuable on account of its regular and enormous yield. Last of August.

Iariana.-A seedling of Wild Goose; round, rather thick skin; a deep cardinal red when fully ripe; and of flne quality. Ripens two or three weeks after Wild Goose. 1st cl., ea, 20c; doz., $\$ 2.00 ; 100, \$ 10.00$. 2 to $3 \mathrm{ft}$., ea., 12c; doz., $\$ 1.25 ; 100, \$ 5.00$.

Pottawattamie - Of the Chickasaw family but quite distinct from any other variety. . Perfectly hardy and an immense, early, annual bearer. Fruit is yellow, overspread with bright pink and prominent white dots: flesh yellow, luscious, good. Ripens in July.

\section{ORIENTAL VARIETIES.}

\author{
(June budded trees by mail, $3 c$.each additional.)
}

1st cl., each, 25c; doz., $\$ 2.50 ; 100, \$ 15.00$. J. B., each 15e; doz., $\$ 1.50$.

A unique class of plums, of great beauty and productiveness, The fruit is exquisitely perfumed, with a charmingly attractive bloom. Trees are exceedingly ornamental, with smooth branehes and rich, light green foliage, and quite distinct from other varieties; early and prolific bearers. The flesh is so tirm and meaty that they can safely be shipped long distances, and kept for a long time in excellent condition.

Kelsey's J apan.--Large to very large, heart- | sweet, rich and dry. Tree vigorous and entirely harshaped; rich yellow, nearly overspread with bright dy. Excellent for canning. Last of July. red, with a delicate bloom; flesh flrm, melting, rich and juicy, and remarkably small pit. Tender north of New York City. Very late.

Ogon.-Large, nearly round, with deep suture; of Simon's (Prunus Simoni or Apricot Plum).From China. In color of bark and in many ways resembles the Peach; in odor and flavor it approaches very nearly the Nectarine. Ripens in New Jersey a bright golden yellow, with faint bloom; flesh firm, during August. Hardy. 


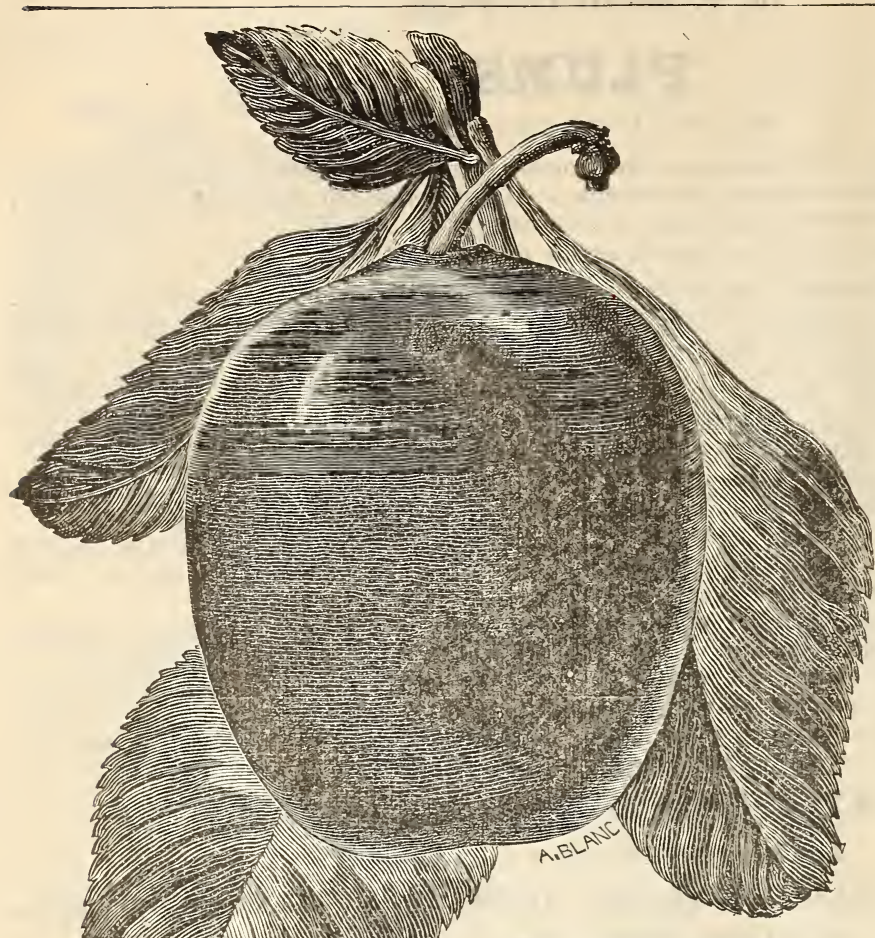

LINCO L N. - Being impressed with the great value of the Plum, and convinced that the fruit is not grown throughout the United States to the extent that its value merits, we have for years been searching everywhere for acquisitions to the list of cultivated varieties-those that were prolifle, handsome and of fine quality, but above everything else, those that escape the attacks of the curculio. Our efforts have thus farresulted in bringing forward the spaulding and Abuudance and gising popularity to several others. We now offer for the first the Lincoln, which,in severalimportant properties, is the most remarkable Plum we have yet seen. It is the largest in size of all hardy plums, average specimens from overloaded irees measure $21 / \%$ inches long and over six inches around, weighing two ounces-selpcted spccimers weighing four ounces each; the finest in quality of any Plum we have ever tested, surpassing its parent, that standard of excellence, the old Green Gage; wonderfully prolific, the plums hanging like ropes of onions upon the branches; beautiful in form and color. veryearly in ripening and curculio-pronf. Like the Seckel Pear, Newtown Pippin Apple and some of our other choicest fruits, the tree is not so strong and rugged a grower in the nursery as might be desired-its only defect thus far noted; but it is, however, entirely healthy and iree from insect attacks.

This marvelous Plum originated in York County, Pa., over twenty-five years ago from seed of Green Gage or Reine Claude; and Lincoln was given it as an appropriate name when it first came into bearing on account of its many merits of high order-Lincoln at the time being President. In color it is reddish purple with a delicate bloom, very bright, showy and attractive; flesh light yellow or amber, exceedingly juicy, rich, swect, melting andluscious-entirely free from any coarseness or toughness-parting freely from the stone. It ripens from the first to the middle of August and its productiveness is simply beyond description, or comprehension until seen. A feature peculiar to the variety lies in the fact that when fully ripe the skin loosens and can be readily pulled from the flesh in the manner of a scalded tomato-this property being made possible by the strength of the skin; which, though nct thick, is so strong as to completely protect the fruit from the attacks of the curculıo.

Mr. E. B. Good, York County $\mathrm{Pa}$. in sending us some specimens of the fruit on August 5th, writes:

"The specimeus I send you by mail (our engrav ng is made from one of them, and is an exact representation in size and form)are of only medium size. Specimens have been grown to weigh four ousces. The tree from which these I send you were picked is just literaliy covered with plums and standing in a stiff sod. It is indeed a fine and wonderful sight to behold. This plum will annibilate dozens of late introduction, and I am sadly mistaken if there is not heaps of money in it for the market grower. Too much cannot be said in its faror."

We have yet but a limited stock of trees of it.

Price, First Class, ea., $\$ 1.00$; doz., $\$ 10.00$. Medium, ea., 75c; doz., $\$ 7.50$, Small, eà., 50c; doz., $\$ 5.00$.

SATSUM A BLOOD. - A fine large plum of the Oriental class, as large as Kelsey, more globular in shape and from five to six weeks earlier. The fiesh is solid, of a purplish-crimson color from pit to skin. juicy and of fine quality. Pit exceedingly small-very little larger than a cherry stone. Tree a strong. vigorous grower with brownish-red bark and lanceolate toliage. H. E. Van Deman, U. S. Pomologist, says of 1 t, "The Satsuma plum is equal to Kelsey in size and quality. It is as red as blood inside. A month earlier than Kelsey and probably hardier, it may prove more valuable for the North where the Kelsey does not succeed." 1st c., ea., 50c.; doz., \$5.00 J. B., ea., 35c: doz., \$3..50. 


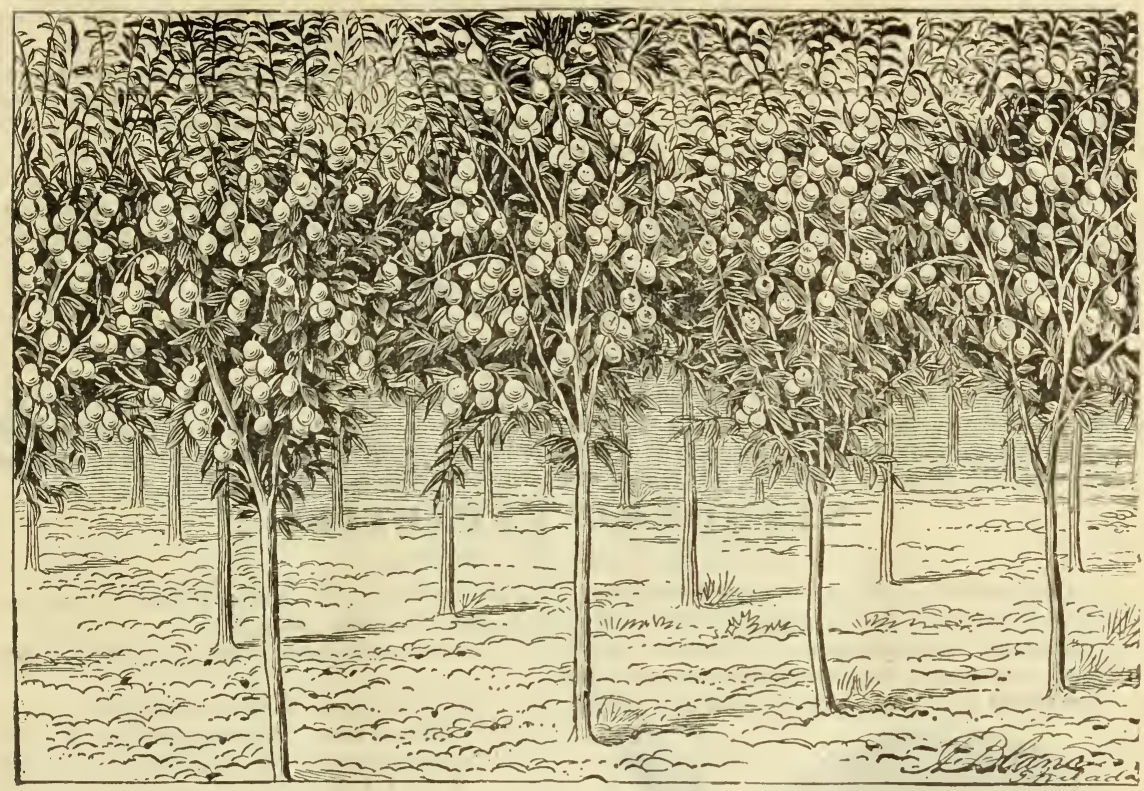

Yodng Trees of ABCNDANCE PleM in Nersery Rows.

A B UN D A NCE. - This is a remarkable fruit indeed. It is unlike any other plum. In growth it is so strong and handsome as to render it worthy of being planted as an ornamental tree-equaling in thrift. and beauty, Keiffer pear which it e: in excels in early and proflis ' bearing. It is exceedingly hardy. Its propensity for eurly bearing is such that it loads in the nursery row, bending the limbs with the weight of fruit until they sometimes break and this is the case cvery ycar-the curculio having no effect upon it, the eggs failing to hatch and produce the destructive grub the same as with the Spaulding. We have seen even little one year old saplings, but two feet high, white with bloom and set heavily with large, flne plums. The fruit is large, showy and beautiful. Amber, turning to a rich bright cher ry color will a decided white bloom, and highly perfumed. Flesh light yellow, ex ceedingly juicy and tender and of a delicious sweetness impossible to describe. Stone small and parts readi.y from the flesh. For canning it is also of the greatest excellence. Its season is very early, ripening in advanci: of other plums (early in August at Monmouth), adding to its special value. No one need longer be withcit plums; for all who plant trees of ABCNDANCE will have an abundance of plums. - 1st c., ea , 50c: doz, $\$ 5.00 ; 100, \$ 25.00$. Medium, ea., 35c.; doz., \$3.50 $100, \$ 20.00$. June Budded, ea., 25c.; doz., \$2.50; 100, $\$ 15.00$.

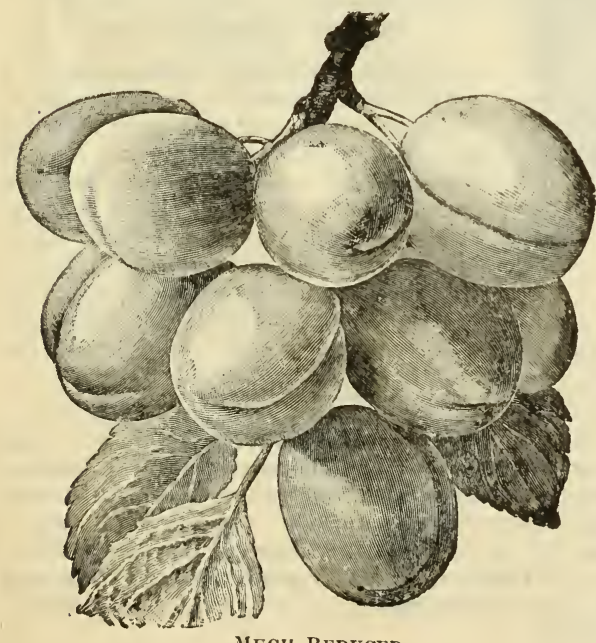

SPAULDING.

The Spaulding is a curculio-proof plum, and its curculio enduring proclivity is not its only merit. Unlike most other so-called curculio-proof plums of which we have any knowledge, it does not belong to the Chickasaw or A merican species; but has descended from the same species as Green Guge, Coe's Golden Drop, Lombard, etc. It is not exempt from the attacks of the "Little Turk," any more than other varieties of the European Plum, but for some reason the wound is soon outgrown, the plums develop fair and perfect and no harm is done. The tree is a remarkable grower, with leathers, iarge, rich dark foliage. It ripens middle of August. The fruit is large, of the form shown, yellowish green with marblings of a deeper green and a delicate white bloom; flcsh pale yellow, exceedingly firm, of sugary sweetness, though sprightly and of great richness. parting readily from the small stone. When canned. it presents not only a most attractive appearance but the quality is simply superb. Owing to the great demand the supply of trees is limited this spring. 1st class ea., F5c.; doz., \$7.50. Medium ea., 60c.; doz., $\$ 6.00$

(37) J. B. ea., 50个: doz., $\$ 5.00$. 


\title{
J. T. Lovett Co.-Plums, Apricots.
}

Saratoga.--Originated near Saratoga Springs, for which it is named. It is an exceedingly promising plum and likely to prove a protltable market variety. The tree is of vigorous growth and very proliflc, coming into bearing early and seldom fails to mature a good crop. The fruit is of large size, of a bright reddish-purple color, covered with abundant bloom, roundish-obovate in form and of excelleut quality. The firmuess of its flesh and its good-keeping properties render it valuable for shipping. 1st cl., ea., 50c; doz., $\$ 5.00$.
Burbank. - A valuable Oriental plum, in general character very similar to Abundance, but of deeper color and ripening later in the season. The fruit is large, and varies less in size than any other Japan plum; nearly globular, clear cherry red with a thin lilac bloom; flesh a deep yellow, very sweet with a peculiar and very agreeable flavor. The tree is a vigorous grower, with large and rather broad leaves; begins to bear usually at two years old. 1st cl., ea., $50 \mathrm{c}$; dcz.. $\$ 5.00 ; 100, \$ 25.00$. June budded, ea., 25c; doz.. \$2.50.

\section{APRICOTS.}

(Plant 15 feet apart each way.)

There is no fruit more delicious or beautiful than the Apricot, and its ripening between Cherries and Peaches renders it especially valuable. Its chief enemy is the curculio, which can be kept in check by the methods suggested for plums. It succeeds admirably trained in espalier form. On the Pacific Coast and throughout the West and Southwest, it excels all other fruit both in merit and popularity.

\section{STANDARD VARIETIES.}

\author{
1st cl., ea., 25c; doz., $\$ 2.50 ; 100, \$ 15.00$.
}

Alexander.-An improved Russian variety. An immense bearer. Fruit of large size, oblong, yellow flecked with red, flavor sweet and delicious; tree hardy, one of the best. July 1st.

A lexis.-Improved Russian. Large to very large; yellow with red cheeks; slightly acid but rich and luscious; tree hardy and abundant bearer. July 15 th.

B R EDA.-Small, round, orange; flesh orange, juicy, rich, vinous; free, hardy, prolific, popular.

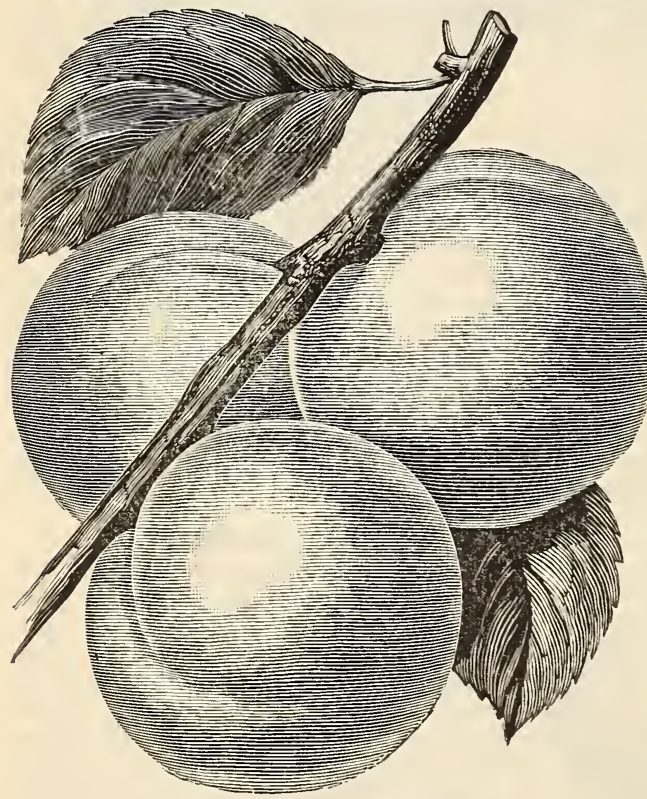

ACME APRICOT. Fig. 1633

Catharine,-Improved Russian. Medium; yellow; mild sub-acid, juicy, good. July 20th.

Early Golden (Dubois).-Small; pale orange; flesh orange, juicy, sweet. Hardy and productive.

Gibb.-Improved Russian. Medium; yellow, sub-acid, rich and juicy. The best early sort, ripening with the strawberry.

J. L. Budd.-Improved Rassian. Large; white with red cheek; sweet, juicy, extra flne; a hardy, strong grower and profuse bearer. The best late variety. August 1st.

N oorpark.-Large; yellow and red: flesh orange, sweet, juicy, rich; very productive, reliaule.

H oma n.-Medium oval; yellow; fine grained, excellent, hardy. proliflc, reliable.

Royal.-Large; yellow and orange; juicy, rich, and delicious; a very fine variety.

\section{NEW VARIETIES.}

A CIIE, SHENSE or CANTON - A new apricot originated by Prof. J. L. Budd, in Iowa, from pits received from the Province of Shense in N. W. China. The tree is a free and vigorous grower, exceedingly hardy and productive. Fruit of large size, yellow with red cheek, gond quality; freestone. Prof. Budd says of it: "After testing the hardiness of the tree and value of the fruit I named it Shense. It is a flne grower w th large, handsome, thick foliage, and an early bearer of large and good fruit. In all respects it is the best hardy apricot I know of, and much better than any Russian sort I have seen in this country or in Russia." 1st cl., ea., $50 \mathrm{c}$; doz., $\$ 5.00$. June budded, ea., $35 \mathrm{c}$; doz.. $\$ 3.50$.

Summiт Co., O., July $7,1891$.

The trees and plants I bought of you last spring are growing flnely. The size, quality and condition of the stock was perfectly satisfactory; and the pricewell ! if you can live on such figures, others are getting rich in the tree business. I shall send you another order next season. Yours truly, Chas. H. ElliotT.
JEFFERSON CO., IND., JuIY 24, 1891.

My trees have done splendidly, and some of the trees that I set out in the spring of ' 90 sre bearing a sample of splendid fruit. I have not lost 25 trees out of the 3000 ordered of you. JOSEPH M. CRAvENS. NoBle Co., O., Aug. 31, 1891.

I planted 700 of your peach trees last spring and lost but one tree.

C. I: MCKEE. 


\section{CHERRIES.}

Plant Hearte and Bigarreaus $20 \mathrm{ft}$., apart each way, and Dukes and Horellos 12 to $15 \mathrm{ft}$.

Cherries will not succeed on wet soil. The class Hearts and Bigarreaus or "sweet cherries" are even more unlike the class Dukes and Morellos or "sour cherries" in habit of tree and growth than in fruit. The trees of the sweet class are to be preferred for shade, for which purpose they are excellent.

First class, ea., 25c; doz., $\$ 2.50 ; 100, \$ 15.00$.

\section{HEARTS AND BIGARREAUS.}

HLACK EAGEE. - Large; flesh purplish crimson, tender, rich; reliable. Midseason.

BIack Tartarian.-Large; juicy, rich, mild ánd sweet; vigorous and productive. Early.

Coe's Transparent.-Medium; pale amber, beautifully mottled; very tender, sweet, juicy; very valuable, popular. One of the best. Eariy.

Downer's Late.-Medium; red, luscious, tender, rich; reliable and a good keeper. Late.

Gov. Wood.-Large; yellow sbaded with light red; juicy, very delicious. Early.

Luelliug.-One of the flnest of cherries. Extremely large; black, very solid, and of the bighest quality. Very valuable. Midseason,

Napoleon.-Very large; pale yellow and red; orm, sweet, profitable. Midseason.:

Hockport. - Large; clear red shaded with pale amber; flrm, juicy, sweet, excellent. Early.

Yellow spanish.-Very large; yellowish. white tinted rose; juicy, rich, sweet; very popular, valuable. Midseason.

\section{DUKES ANDZMORELLOS.}

Belle de Choisy.-Medium; amber mottled; delicious; a shy bearer. Midseason.

Early Richmond (Early, May, Kentish, Pie Cherry).-Medium; red: juicy, acid, popular. Very productive and hangs loug on the tree.

Empress Eugenie.-Large; dark red; excellent; good grower and productive. Late.

English Iorello.-Large; dark red; juicy, rlch, acid; productive and very profltable. Late.

Late Duke.-Large; dark red; flesh pale a mber sub-acid, flne. Late.

Louis Plnillipe.-Medium;iich, dark purplis red; juicy, mild sub-acir. Late.

II ay Duke.--Large; dark red: melting, rich, juicy, excellent; popular, reliable. Early.

Montmorency Ordinaire.-Large; bright red; acid: larger and later than Early Richmond.

Olivet.-Large; deep red; tender, rich, vinous. A choice variety. Early.

Leine Hortense.-Large; red, mottled; Juicy, tender, rich; one of the best. Late.

\section{NEW VARIETIES.}

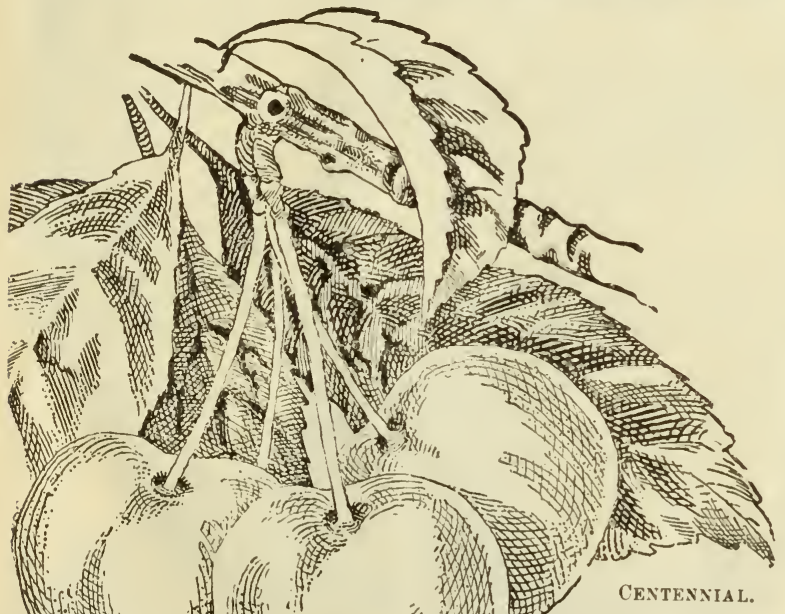

Centennial. - The most wonderful:cherry we haveever seen. The great drawback to the culture of the cherry, espec. ially Hearts and ${ }_{\mathbf{B}}$ Bigarreaus, is their perishable :nature-every light colored variety in general cultivation being subject to quick decay. The Centennial, on the contrary, is so enduring in texture that it can be kept in good condition almost indefnitely. On two occasions ripe specimens seut us by mail from Califorvia were not only received in good condition, but remained so for several days after arrival. Ripe specımens have been kept in an ordinary room for a month after gathered and were still in eating condition. In addition to its remarkable keeping properties, the fruit is of immense size, beautiful amber shaded red with very firm yet tender flesh; sweet, rich and luscious. It is a seedling of Napoleon Bigarreau which it resembles in appearance but is much larger and more oblate in form. Tree an extra good, straight and handsome grower. No other cherry can compare with it for canning. Its sweetness is very pronounced being exceedingly sugary. Its crispness and honied sweetness make it a desirable table fruit, but its great value is in its firmness which makes it probably the best shipping cherry yet introduced. Ripens in midseason. Ist cl., ea., 75c; doz., \$7.50. 1 yr., ea., 50c; doz., \$5.00.

Ostheim.-A German cherrv somewhat resembling the Russian Vladimer, especially in foliage, habit of growth and color of fruit. Large; red, when fully ripe a dark red; flesh red, tender, juicy, pleasant. Tree exceedingly hardy; a vigorous grower and productive. 1st cl., ea., $35 \mathrm{c}$; doz., $\$ 3.50$. 


\section{QUINCES.}

Plant 10 feet apart each way; 435 per acre.

The quince thrives best in a deep, strong, moist soil; although Fuller and Meech's Prolific will succeed in almost any kind-the latter performing wonders in a soil of white, leachy sand. But all quinces require thorough culture, vigorous pruning and a free use of fertilizers. Potash ard salt are recommended as a dressing for this fruit. Its greatest enemy is the borer which must be diligently destroyed.

(Small trees by mail, 3c. each additional.)

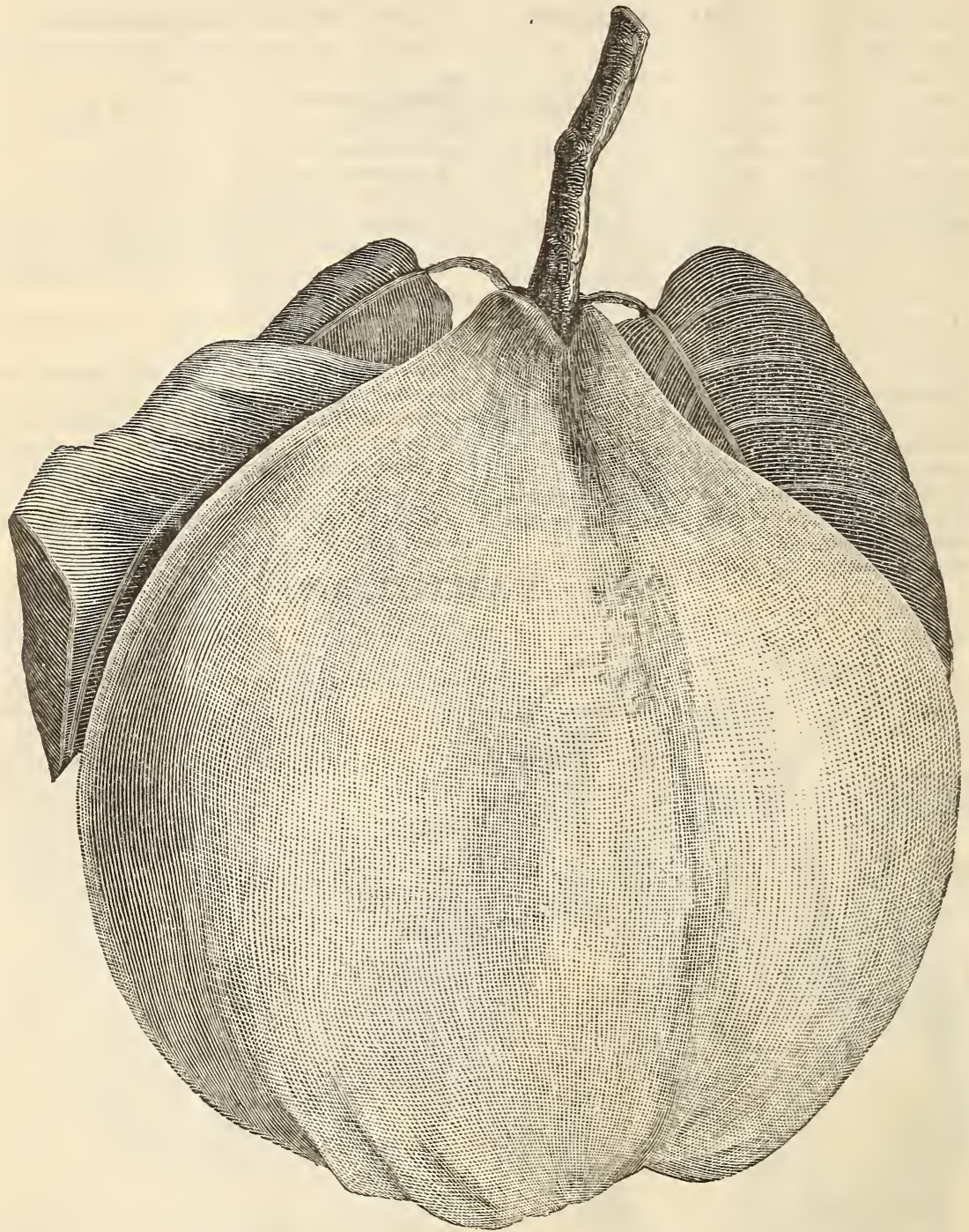

A NEW QUINCE-THE FULLER.

[From the AMERICAN AGRICULTCRIST, January, 1886.]

"Our associate, Mr. A. S. Fuller, so widely known as a pomologist, brought us in October last some specimens of a fine quince, unlike any other we had seen. Upon learning the history of this frult we quite agree with Mr. Fuller that it is new and worthy to be added to the very small list of varieties. Soon after Mr. Fuller removed to his present place at Ridgewood, N. J., he noticed upon a neighboring farm a young quince tree, the fruit of which appeared to him to be unlike any of the well-known varieties. The farmer being willing, Mr. F. took some cuttings of the tree and planted them. The farm was soon after sold to a gentleman from the city, and in erecting a dwelling for the new-comer, the masons, carpenters and 


\section{J. T. Lovett Co。-Quinces.}

others broke down the tree, wh $\mathrm{h}$ was a small one, and completely destroyed it. The cuttings which Mr. Fuller had providently planted formed bearing trees in an unusually few years, and now that his own trees yield fruit, it is very evident that it is an entirely new variety. What first arrested Mr. Fuller's attention was the showy character of the fruit, which cast off its downy covering and assumed a rich golden yellow color very early in the season, thus making it the most ornamental of all the quinces. The engraving represents the largest of several that were brought us, reduced one-third of its real size. This specimen weighed nineteen ounces. Another characteristic of the variety is its abrupt and long neck, which is much more striking in smaller specimens than in the one here flgured. In some, the neck is hardly larger than one's flnger. [The engraving referred to is one that appeared with this article in the Agriculturist, and is not the one we present. $]$ The fruit when cooked is exceedingly tender throughout, and the flavor, a point in which some of the very large varieties are deficient, is in this nost excellent. At our earnest solicitation Mr. Fuller has consented to allow this fine variety to go into thetrade. He proposed to give it the name of the farmer who owned the place on which the original tree was discovered. We propose to overrule this decision and call it the "Fuller," as he was the means of saving the whole stock from complete extermination. So far as the fruit goes, the Fuller Quince may be described as follows;-Fruit large to very large, distinctly pyriform, often with a very abrupt and small neck; the surface somewhat ridged; the skin assuming a rich yellow color early in the season; calyx set in a deep, wide basin; flesh remarkably tender and well flavored. Should the tree and foliage present any marked peculiarities, they will be mentioned at another time. The quince is a most showy tree both in flower and fruit, and the Fuller will be especially valuable to plant for ornament on account of its exceptionally large and brilliant fruit."-GEO. THURBER.

Knowing a fruit that two such able horticulturists as Dr. George Thurber, editor of the AMERICAN AGRICl LTURISt, and Mr. A. S. Fuller, author SMall Froit Celterist, GRAPE Culturist, Agricultural Editor NEW YORK SUN, \&c., esteemed so highly inust possess great value, we lost no time in calling upon our friend Fuller. On seeing the trees almost breaking down with their load of large, fair, beautiful fruit, and with the largest, smoothest, cleanest foliage we ever saw upon quince trees, we also became enthusiastic and entered into a contract with Mr. Fuller whereby the sole right to propagate the marvel for a term of years was secured to us-purchasing at tho same time one of the three large trees of it (for which, by the way we paid one huudred dollars), and have now succeded in growing a limited nu nb"r of handsome nursery trees of it. The large tree purchased of Mr. Fuller was sent us in November, 1886, and to our delight and astonishment produced the following year twenty-four perfect specimens. From one of the eur illustration was made, one was sent to our friend Wm. Parry, three to the Fruit Exhibition of the AMrRICAN INSTITUTE FAIR, (receiving a special premiuin for large size, beauty and excellence) and the balauce were cooked; proving of the superior quality described by Dr. Thurber. The tree has continurd fruitful each year since, and in beauty of growth and foliage is beyond comparison with any other quince we have ever had anything to do with.

Wm. Parry wrote November $3 d, 188 \pi$, in regard to the specimen we sent him as folfows: - "We are much pleased with its fine appearance, perfect and distinct form, while its beautiful yellow color makes it very attractive. The specimen when received was partly decaved, but weighed about 10 ounces, and measured 11 inches round - a very good showing tor a tree the first year planted." The following from the pen of Samuel Miller, we clip from CoLMAN's RURA.. WorLD, October 28th, 1886:- "On October 9th we received a Fuller quince from our friend, A. S Fuller, as perfect as a quince could possibly be. It measures 11 inches in circumference, and weig..s 12 ounces."

At Monmouth no quince except the Fu:ler has proved a perfect success. It is therefore not only the largest, handsomest and best, but also the most reliıble variety yet produced.

Price, First Class, ea., $\$ 150 ; 3$ tor $\$ 4.00 ; 6$ for $\$ 7.50 ; 12$ tor $\$ 15.00$. Small, ea.. $\$ 1.00 ; 3$ for $\$ 2.50 ; 6$ for $\$ 4.50 ; 12$ for $\$ 8.00$.

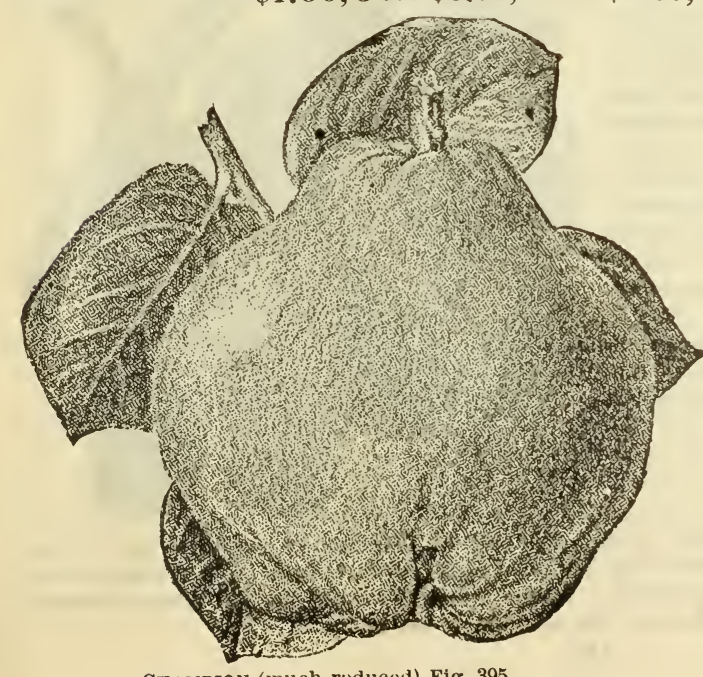

ChaMpion (much reduced) Fig. 395.
Cham pion.- Tree extremely hardy, of stout, rugged, upright growth, ascending in a single stem, with smooth bark-resembling a standard pear tree more than a quince. A profuse and regular bearer, and its early bearing is remarkable, commencing to produce fruit at three and four years old. Fruit large, obvate pyriform in shape and of a lively yellow color, rendering it very showy and handsome. Flesh tender and free from the hard lumps so common in other quinces. Ripens about two weeks later than the Orange, and will keep until Christmas. It is subject to blight, but when well grown where the season is sufficiently long to enable it to ripen perfectly it is a mag niflcent quince, and its size and beauty causes it to sell readily at profitable prices. 1st. c., ea., 25c; doz., $\$ 2.50$; $100, \$ 15.00$. Extra, ea., 35c; doz., $\$ 3.50$; $100, \$ 20.00$. Small, ea., $20 \mathrm{c}$; doz., $\$ 2.00$ $100, \$ 10.00$. 


\section{J. T. Lovett Co.-Quinces-Mulberries.}

MEECH'S PROLIFIC.-This valuable new quince possesses merits that render it in every waya

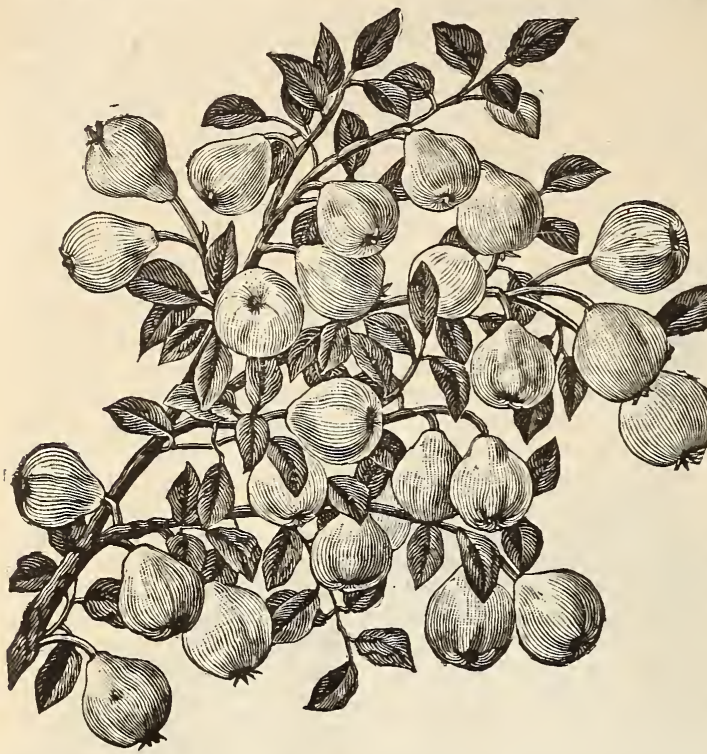
most desirable variety both as regards the trees and their fruit. It is remarkable for its early and regular bearing, and for wonderful productiveness, sometimes bearing when only two years old and afterwards so abundantly that a vigorous thinning of the fruit is required to prevent injury from overbearing. The fruit also is remarkable for its flne form and color, high fragrance and flavor. It is shaped like a handsome pear with a smooth, flne skin of a bright orange yellow, and quite large, averaging under good culture 8 to 10 ounces each. Flesh of the most delightful fragrance and delicious flavor; a 3asket of this fruit,fully ripe,perfuming a large room with its delicate aroma. Its cooking qualities are unsurpassed. It is admirably adapted to.making marmalade from the tenderness of its pulp; and by reason of its excellent flavor it makes the most delicious jelly. Its rich flavor is so strong that many persons are better pleased to reduce it by adding apples in equal quantity. Its beauty of form and color, and holding well its leaves until late in autumn renders the tree an attractive ornament to the home grounds. It ripens later than the Orange Quince and earlier than Rea's Mammoth, Champion and other leading sorts. 1 st c., 2 to $3 \mathrm{ft}$., ea., $25 \mathrm{c}$; doz., $\$ 2.50 ; 100, \$ 15.00$. Extra 3 to $4 \mathrm{ft}$., ea., 35c: doz., $\$ 3.50 ; 100$. \$20.00. Small, ea, 15c; doz., $\$ 1.50 ; 100, \$ 10.00$.

Orange.-The well-known and popular sort Rea's Mammoth.-A seedlingof the Orange sometimes known as the Apple Quince. Large, of a Quince, very much larger and a great improvement rich golden yellow, and of fne quality. When prop- upon it. A strong grower and under good cultivaerly grown it is both productive and profltable. Sea- tion, productive. A popular variety with many son quite early. 1st c., ea., 25c; doz., $\$ 2.50 ; 100$, growers. 1st. c., ea., 35c; doz., \$3.50; $100, \$ 25.00$. $\$ 15.00$. Extra, ea., 35c; doz., $\$ 3.50 ; 100, \$ 20.00$. Extra, ea., 50c; doz., $\$ 5.00 ; 100, \$ 35.00$. Small, ea., Small, ea., 15c; doz., $\$ 1.50 ; 100, \$ 10.00$.

\section{MULBERRIES.}

Downing's Mulberry.-It is surprising that this noble tree is not more generally planted than it is, when we consider its value as a shade tree for the lawn or around the house and the abundance of its sweet berry-like fruit. This is the finest variety of mulberry yet introduced, and its rapid growth, profusion of foliage of such deep verdure and dense shade should give it popularity. It is a charming ing tree with a shapely and compact habit and form; long-lived, and its wood is very durable: The fruit is very abundant, of the shape shown in the illustration and of about the diameter of blackberries. It is sweet, delicious and refreshing and is borne from July until late in autumn. It is free from the mawkish, cloying sweetness of other mulberries and is really very good. Poultry are particularly fond of it and eat it greedily. We regard it as especially desirable for planting in grounds of only limited extent, such as the village door yard, where but one or two shade trees are grown. For this purpose it is not excelled by any other tree and no one will regret planting il. 50c, each.

Russian(M. Siberica).-Hardy, rapid-growing

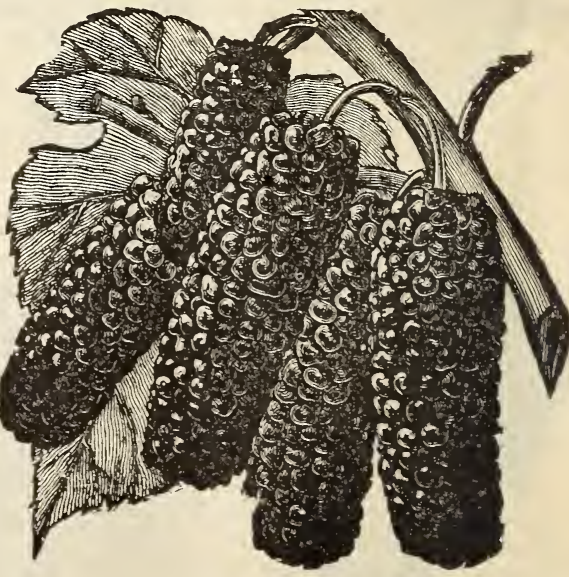
timber tree of value; useful in silk culture. Fruit small and of little value. Especially hardy along the seashore and in the Northwest. For those who live in the cold North, it will prove a desirable acquisition to the number of trees suited to the lawn, having endured without harm a winter tempera. ture of 40 degrees below zero. 6 to $8 \mathrm{ft}$., ea., $25 \mathrm{c}$; doz., $\$ 2.50 ; 100,812.00$. 


\section{J. T. Lovett Co.-Hardy Orange, Horticultural Books.}

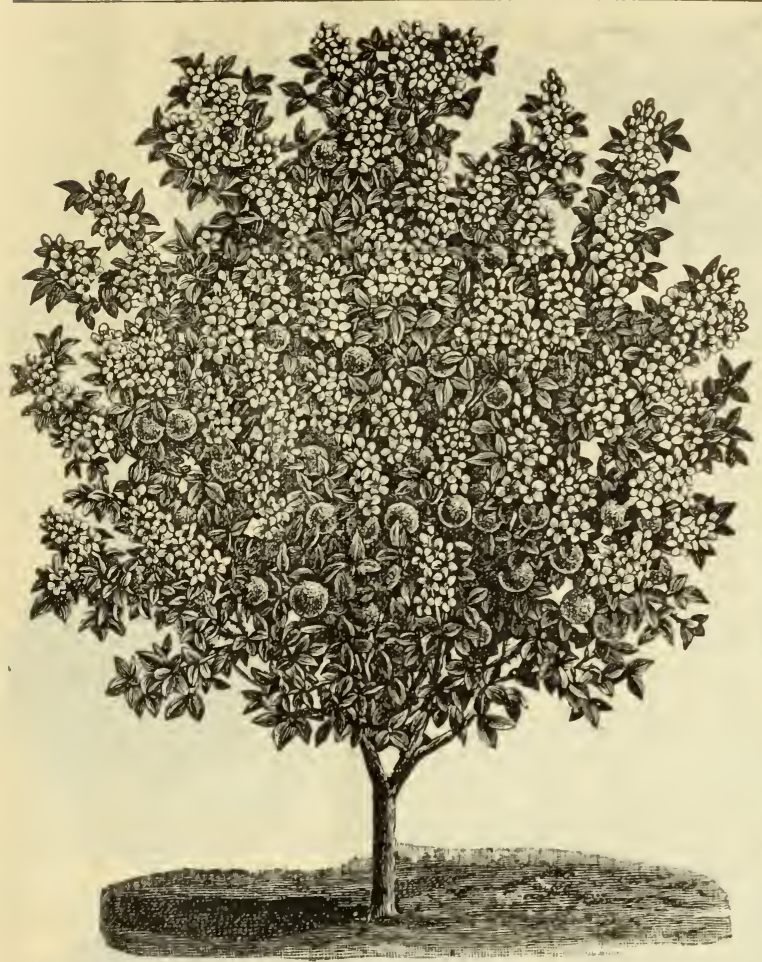

\section{HARDY ORANGE.}

Citrus trifoliata. - This has now been in our test grounds for over three years. and, we are pleased to state, has proved entirely hardy without protection; a fact we would not belfeve until we had proved it. The Oranges, though small in size compared with those in the markets, are exceedingly eautiful. They are. however, too cid to eat out of hand; being used $s$ lemons for makıng a refreshing nd pleasant drink. It fruits freely ind blooms in spring with wonderiul profusion. The blossoms are large, pure white and impart the same exquisite fragrance as other oranges. In habit the tree is dwarf, upright, and with abundant, rich, dark green, three-lobed foliage: which remains upon the tree until after frost, and then falls. So valuable as to well merit cultivation for its beauty alone; or for its delightfully fragrant blossoms which are produced in greater or less numbers during almost the entire spring, summer and autumn. Its advantages is a hedge plant are its natural dense habit of growth and the abundance of its sharp thorns. It is naturally a dwarf tree and will need but little trimming to keep it within bounds. It has safely withstood a temperature of $18^{\circ}$ below zero entirely unprotected. $1 \mathrm{yr}$. ea., 15c; doz., $\$ 1.50 ; 100, \$ 6.00 .2$ yrs. ea.. 25 c; doz. \$2.50; 100, \$15.00:"(hy mail 3c. ea. extra.)

\section{HORTICULTURAL BOOKS.}

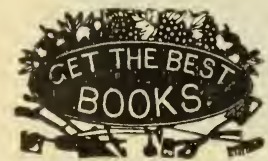

The following books are standard works and the best of their kind. Sent postpaid on rectipt of price.

FUngus Diseases of the GRaPe and (Other Plants.-By Prof. F. Lamson-Scribner. The most valuable book of its time dealing with an important subject in its lat est aspects. T e author is the foremost authority in America, upon Fungus Diseases, and he handles his subject in an autboritative and practical manner. It gives full descriptions of each disease, its nature, remedy and mode of treatment. Copiously illustrated from original drawings expressly prepared for lt. Price in paper cover, 50c. ; bound in cloth, $75 \mathrm{c}$., by mail postpaid.

FULLER'S GRAPE CULTURIST--A standard work on the subject: eminently practical, and exceedingly interesting: should be in the hands of all who grow grapes. Fully illustrated. Price $\$ 1.50$.

FULLER's SMALL FRUit CULTURIST. - The nost valuable work on the subject extant. It covers the whole ground of Propagation, Culture, Varieties, Picking, and Packing for Market, etc., and is specially devoted to Small Fruits. Profusely illustrated. Price $\$ 1.50$.

AMERICAN FrUIT CULTURIST.-A valuable work, covering the entire fleld of the propagation and culture of both Orchard and Small Fruits, recently revised and brought down to date by the author, J. J. Thomas. Fully lllustrated: nearly 700 pages. A valuable work at the low price of $\$ 2.00$.

BARRY'S FRUIT GARDEN. - Writte? by P. Barry, who has had years of practical experience as a nurseryman and fruit grower and who thoroughly understands the work he has treated in this book. Over 500 pages, revised and enlarged. Fully illustrated. Price $\$ 2.50$.

DownING's FRUITs AND FrUIT TREes of AMERICA.-An encyclopedia of Pomology. New edition. The author spent a long life in the study of pomology, and has left this enduring monument for the beneflt of generations to come. It describes the culture, propagation and management of the Orchard and Garden and of Fruit Trees generally, and mentions all the fnest varieties, both native and foreign, cultivated in this country. One thick volume of over $1,2: 0$ pages. Price $\$ 5,00$

INJURIOUS INSECTS OF THE FARM AND GARDEN.-By Mary Treat. A valuable and interesting work giving an account of the most destructive insects and the present knowledge of the methods of preventing their ravages. Invaluable to the fruit-grower. Fully illnstrated. Price $\$ 2.00$.

SCOTT'S SUBURBAN HOME GROUNDS.-A treatise on the art of beautifying Home Grounds of small extent, fllustrated by upward of 200 plates and engravings of plans for residences and their grounds, of trees and shrubs, and karden embellishments; also descriptions of the beautiful and bardy trees and shrubs grown in the United States. Over 600 pages handsomely bound in cloth. Price $\$ 3.00$.

AMERICAN GRAPE GROWING AND WINE MAKING.,-By George Husmann. A standard work on the subject embodving the methods and opinions of eminent grape cultivators in all parts of the countrv. Copiously illustrated. Price $\$ 1.50$.

WHITE'S CRANBERRY CULTURE.-Contains minute directions for growing cranberries profitably. Illustrated. Price $\$ 1.25$.

J. T. LOVETT CO., Little Silver, N. J. (43) 


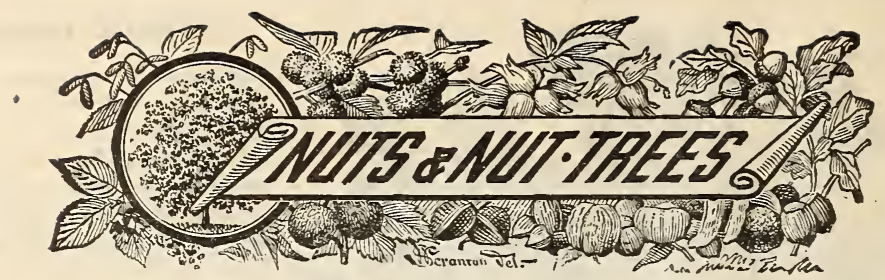

Space will not permit us to give detailed instructions for the cultivation of nuts. Chestnuts, Walnuts and Hickories, however, will succeed if given the same treatment as apple or pear trees, and should be planted about the same distance apart, with the exception of the Dwarf English Walnut; which may be planted much closer. Filberts require no other culture than occasional pruning. Almonds should be given the same culture as the peach, to which they are closely allied. We cannot supply nuts of any of the varieties offered, as we keep in stock only the trees.

Small trees, of those varieties marked with an asterisk (*) will be mailed for $3 c$. each additional.

\section{ALMONDS.}

*Hardshell.-A fine, hardy variety, with a large

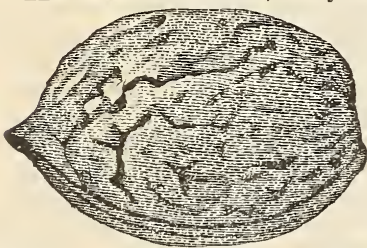

plump kernel and with large, showy, ornamental blos soms. The hull cracks when the iruitripens permitting the nut to diop out. Trees at th Monmouth Nur sery produce abundantly. 1st c., ea., $25 \mathrm{c}$; doz., $\$ 2.50 ; 100, \$ 15.00$ Small, ea., 15c; doz., $\$ 1.50 ; 100, \$ 10.00$

* Soft o re a per slue

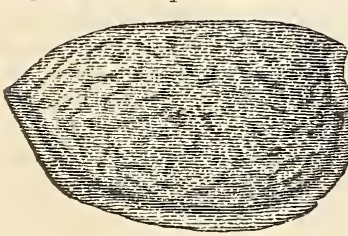

as the Ladies' Almond orLadyFinger of the shops; and although preferable to the hardshell it is not so hardy. Kernel sweet and rich. Prices same as for hardshell. 1st c. ea., $25 \mathrm{c}$; doz. $\$ 2.50 ; 100, \$ 15.00$

Small, ea., 15c; doz., $\$ 1.50 ; 100, \$ 10.00$

* Russian.-In this we have what has so long been wanted, namely, an almond perfectly hardy at the North. Unlike other almonds which descend from the Peach this one is an offispring of the Russian Apricot, inheriting the hardihood of its parents. The tree is of good growth and prolific, the nuts large with plump, sweer, rich meat. 1st c., ea., 50c; doz., $\$ 5.00$. Small, ea., 30c; doz., $\$ 3.00$.

\section{CHESTNUTS.}

*Spanish or llaroon. $-A$ handsome, round-

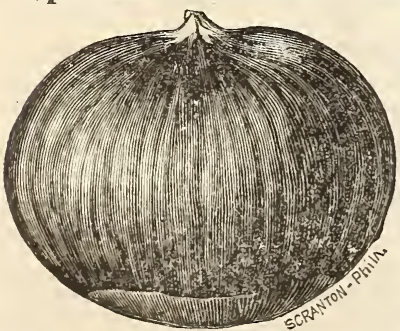

headed,state ly tree of rapid $\mathrm{grow}$ th that yields abundantly of very large nuts; hence valuable both for ornament and fruit. A gentleman of our acquaintance realizes a profit of $\$ 50$ a vear on an average from

the sale of nuts of two trees of this variety. 4 to

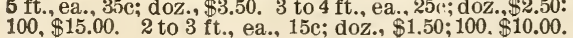
Small, ea., 10c; doz., $\$ 1.00 ; 100, \$ 7.00$.

Hathaway. - A purely native of great merit. It originated with $\mathrm{Mr}$. B. Hathaway of Michigan, the originator of the Bidwell strawberry and other new varieties of fruit. It is very large for its class and possesses to an unusual degree the sweetness and ine quality of the native chestnut. The hope of obtaining large and flne chestnuts of good quality lies in the improvement of our native American nuts and the Hathaway is a decided advance in this direction. 3 to $4 \mathrm{ft}$., ea., $25 \mathrm{c}$; doz., $\$ 2.50 ; 100, \$ 15.00$.
* merican orsweet. The well-known chestnut of the forest. In sweetness and delicacy of flavor or as a shade tree unsurnassed. It is of fine growth and one of the best for avenue planting, being handsome and symmetrical. $31 / 2$ to $5 \mathrm{ft}$., ea., $20 \mathrm{c}$; doz., \$2.00. Small, transplanted, ea., 10c; doz. $\$ 1.00 ; 100, \$ 5.00$.

*Japan Giant.-Distinct in growth from either the European or our American Chestnut, entirely har-

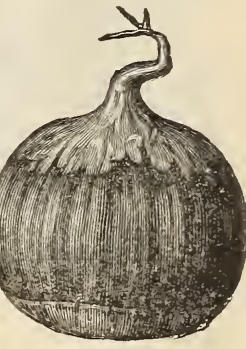
dy, very prolific, and comes into bearing when but two or three years old. At vionmouth Nuisery. trees but three years planted bear abundantly, and the

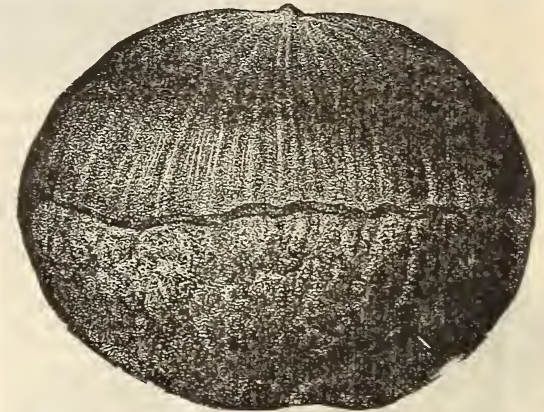

most remarkable fact is that some of the burrs contain as many as seven large, perfect nuts. The nuts are of large size and of the flavor and sweetness of the native. Many clear-headed farmers and others are planting it largely for profit, and all should plant at least some. The trees we offer are the true Giant-seedlings from monster sees. larger than the engraving shows. 2 yrs., 2 to $3 \mathrm{ft}$., ea., $50 \mathrm{c}$ : doz. $\$ 5.00 ; 100, \$ 25.00$. 1yr., ea., $25 \mathrm{c} ;$ doz., $\$ 2.50 ; 100$, $\$ 15.00$.

\section{FILBERTS.}

These, frequently termed hazlenuts are of the eas iest culture, and are among the most profitable and satisfactory nuts to grow: $n f$ dwarf habit, entirelv hardy, abunoant vielders, succeeding almost everywuere, and coming

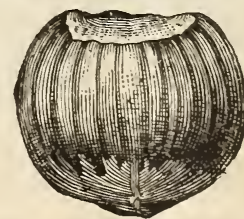

CoMrMon ENGLISH

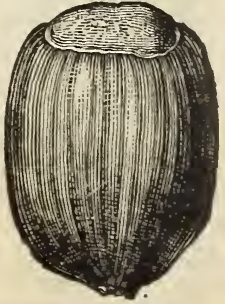

KENTISH COB. into bearing early, as they do, with their rich, tooth. 
some meat, they are worthy of being planted by everybody.

*Cosford.-An old English variety of superior quality and valuable from the thinness of its shell as no nut crackers are needed with it. Oblong in shape and very sweet. 2 ft., ea., 30c; doz., $\$ 3.00$. Small, ea., 20c; doz., $\$ 2.00$

*Kentish Cob.--One of the largest and finest of the fllberts, oblong, meaty and of excellent qualicy.

$2 \mathrm{ft} .$, ea., 30c; doz., $\$ 3.00$. Small, ea., $20 \mathrm{c}$; doz. \$2.00. *ommon in England, and a popular sort. This most largely in England, and a popular sort. This flbert usually sold in the fruit stores. 4 to $5 \mathrm{ft}$., ea., $30 \mathrm{c} ;$ doz. $\$ 3.00 ; 100, \$ 20.00$. 2 to $3 \mathrm{ft}$., ea., 20 i doz., $\$ 2.00 ; 100, \$ 12.00$. Small, ea., 12c; doz. \$1. 100 , $\$ 6.00$.

\section{HICKORIES.}

Not only are these valuable for their fine nuts, but they are among the largest and finest of shade trees, while the wood, on account of its strength and elasticity, is highly prized for the making of agricultural implements, and for other manufaciuring purposes, and it is also unsurpassed for fuel.

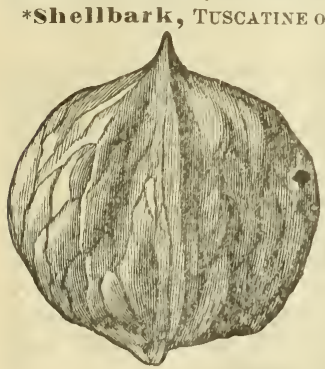

SHAC-BARK. (Carya alla).-Tree of large dy and prod uct ive. Nuts thinshelled; kernel sweet and excellent. Always st lls readily at good prices. The wond is of the greatest value for mechanical purposes and tor fuel. 2 ft. ea. $25 \mathrm{e} ;$ doz., $\$ 2.50$. Smali. transplanted, ea., 15c; doz., $\$ 1.50 ; 100, \$ 9.00$ * Perar in (Caryaoliveformus). - Th is nut so well known and highly prized by all. is of the easiest culture - the tree being of sturdy, lofty growth. Frnm the fact of its

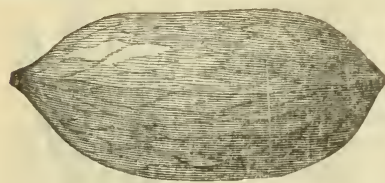

being found in the forests $f$ the South and West many supprise that it is not not hardy at the North, which is entirely errone-

ous. The shell is very thill, the kernel sweet and delicious.

Our trees are the celebrated Gaudaloupe variety, growing on the Gaudaloupe River, and are considered the best and al $\circ$ the earliest bearing. Nuts large and very thin-shelled. $2 \mathrm{ft}$. . ea., 25c; doz., $\$ 2.50 ; 100$, $\$ 15.00$. Small, trans., ea., 15c; doz., $\$ 1.50 ; 100, \$ 8.00$.

\section{WALNUTS.}

The wood of the walnut, once so abundant, is now so valuable and in such great demand that large numbers of trees are being planted for this purpose alone, and the investments will prove profitable.

*English, French or Maderia Nut,

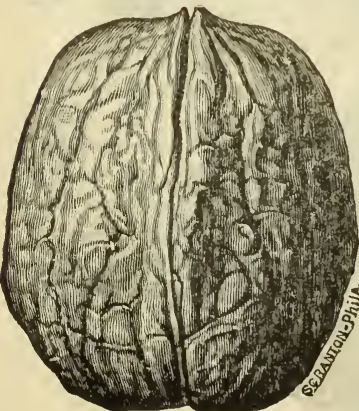
(Juglans regia) - Not only are the delicious thin -shelled nuts prized highiy by all, but from this tree is obtained the beautiful "French curled"walnut lumber, so extensively used in the manufacure of fine furniture. Unlike our American varieties, the nuts fall from the husk when ripe. The tree of lofty growth hardy, and productive from New
York southward. 3 to $1 \mathrm{ft}$. ea., 35c: doz., \$3.50. 2 to 3 ea., 25c; doz., \$2.50: $100, \$ 15.00$. Small, trans., ea., 15c; doz., $\$ 1.50 ; 100, \$ 10.00$.

* Dwarf English, Proeparturiens or Fertile. - A variety of theEnglish walnut possessing many points of merit to commend it, such as early bearing, superior hardiness, and late blooming, by which it escapes the late frosts. The nuts in all respects are very much like the parent unless perhaps a trifle larger. Small, trans., ea., 25c; doz., \$2.50.

*Japan. Juglans S1EBOLDI. - This species is f ound growing wild in the mountains of northern Japan and is as hardy as an oak. It is of easy culture and the tree grows with great rigor. It nature early, bears youn and is more re, $\mathrm{u}$ lar and producglish walnut. The leaves are of immense size, very abundant and form a magniflcent shade. The nuts grow in clusters of fifteen or twenty and are produced in great numbers. 'I'he shell is slightly thicker than that of the English walnut, but not as thick as the black walnut ; meat sweet and of flne quality, fla vor sinilar to the butternut, but less oily and mucli superior. Jigians MAX. CORIIFORMIS.-This is also aJapanese species of walnut, yet little known, resembling in some respects $J$.Sichriddi, but differing con-

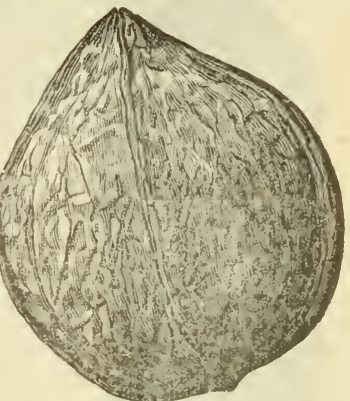

siderably in form of nuts, which are hroad, slightly flattened, with acute points at both extremities, smooth and something like our Shellbark hickory, but larger. 2 yrs old, ea., 50c; doz.. \$5.00.

*Butternut (Juglans cinerca.)-Nuts differ from those of the black walnut in being longer and the kernels of sweeter, more del icate flavor. The wood is also very valuable and the tree of lofty spreading growth. to $4 \mathrm{ft}$., ea., $25 \mathrm{c}$; doz $\$ 2.50 ; 100, \$ 15.00 .2$ to 3 ft., ea., 15e; doz. $\$ 1.50 ; 100, \$ 9.00$

* Black (Juglans nigra).-The common walnut ; the wood is he most beautifuland valuable of all. No one who has ever eaten walnut candywill ever orget the flavor of ts oily and toothsome kernels. 4 to $5 \mathrm{ft}$., ea. 25c; doz., \$2.50. 2 to \$ ft. ea., 15c; doz., $\$ 1.50$ $100, \$ 9.00$.

Thins helled

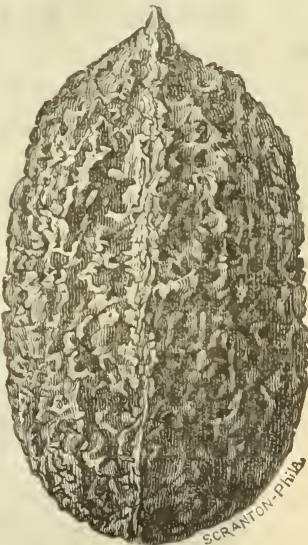

BUTTERNUT.

Black. - A variety of the preceding with unusually thin shells, the kernels coming out whole. In other respects equally as valuable. A decided improve ment. 3 to $4 \mathrm{ft}$., ea., $25 \mathrm{c}$; doz., $\$ 2.50 ; 100, \$ 15.00$. 


\section{GARDEN ROOTS.}

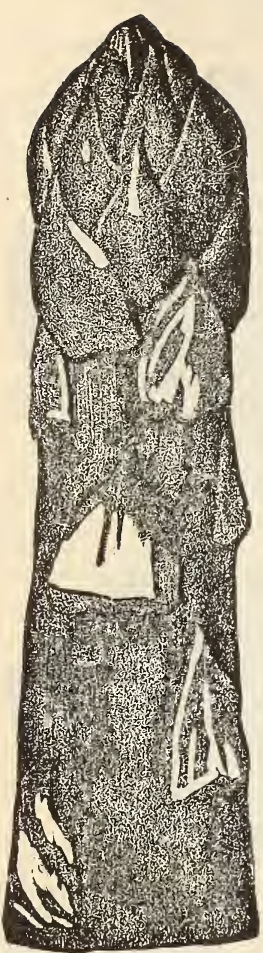

BARR'S MAMMOTH.

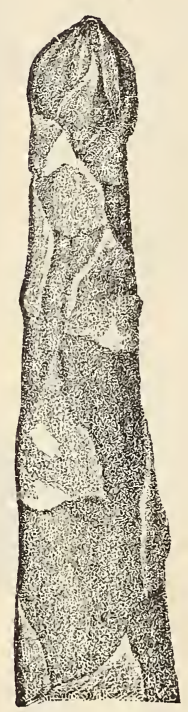

CONOVER's COLOSSAL.

\section{HORSE RADISE.}

(If by mail add 15c. per 100. Free at dozen rates.) Sets.-Doz., 25c; 100, 75c; 1000, $\$ 4.00$.

\section{SAGE.}

(If by mail add $3 c$. each additional.)

Holt's II ammoth.-Forms large plants with :mmense, perfect leaves and seldom runs to seed; exceedingly fine. Ea., 10c; doz., 75c; 100, $\$ 5.00$.

\section{ASPARAGUS.}

(1yr. by mail 25c. per 100 extra. Free at doz, rates.) In garden culture plant in rows three feet apart and roots two feet distant; in field culture plant is rows four and a half feet apart and two feet distant. Set the roots ten inches below the surface and cover with about two inches of soil, flling in the balance by degrees the flrst season while cultivating with horse or with a hoe.

Conover's Colossal. - Large, of rapid growth, productive and of fine quality. $1 \mathrm{yr}$., doz., $20 \mathrm{c}$; $100,50 \mathrm{c} ; 1000, \$ 3.50$. 2 yrs., doz., 30c; 100, 75c: 1000 , $\$ 5.00$.

IBarr' Mammoth.-This is the finest asparagus yet offered for sale in this country, We have tested it for some years and found it the largest and earliest of all we have ever seen. It is a light-color. ed "grass" but enormous in size and at least a week earlier than Smalley's Deflance, side by side. Grown alongside of Conover's Colossal, and subject to the same treatment, it came in earlier and grew more than twice as large. A bunch of 25 edible shoots weighed 13 pounds and is said to have sold in market for $\$ 5.00$. 1 yr., doz., 30c; 100, 75c; 1000, $\$ 5.00$. 2 yss. doz., 40c; $100, \$ 1.00 ; 1000$. $\$ 7.50$.

Palmetto.-A new variety of Southern origin now being largely planted, AS compared with Conover's Colossal, it is earlier, a better yielder, more even and regular in its growth and of fine quality. $1 \mathrm{yr}$., doz., 40c; 100, $\$ 1.00 ; 1000$, $\$ 7.50$. 2 yrs., doz., 50c; 100, $\$ 1.25 ; 1000$, $\$ 9.00$.

\section{RHUBARB.}

PIE PLANT.

(By mail 5c. each additional.)

Plant in rows four feet apart and the plants three feet distant. Set the roots so that the crowns are about an inch below the surface.

Myat's Linnaus.-Early, very large, tender and delicstely flavored. Requires less sugar

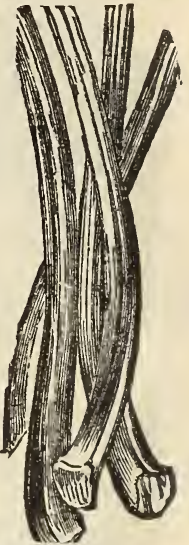
than other sorts. Ea., 10c; doz., 75c; 100, $\$ 3.00$.

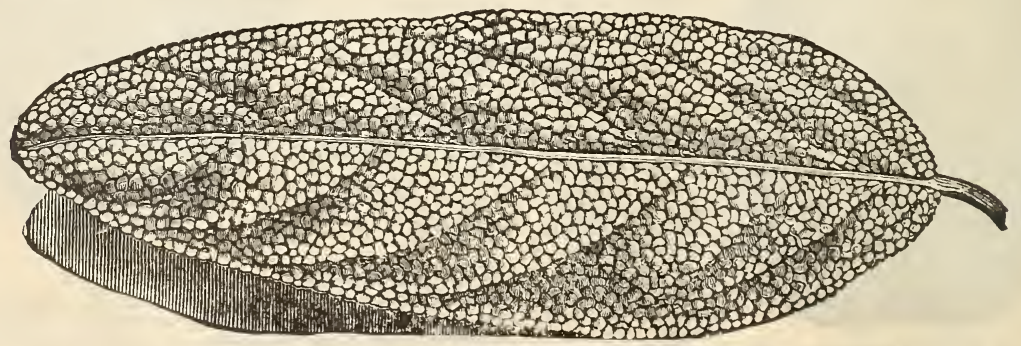

Leaf of Holt's MaMmoth SAGE. 


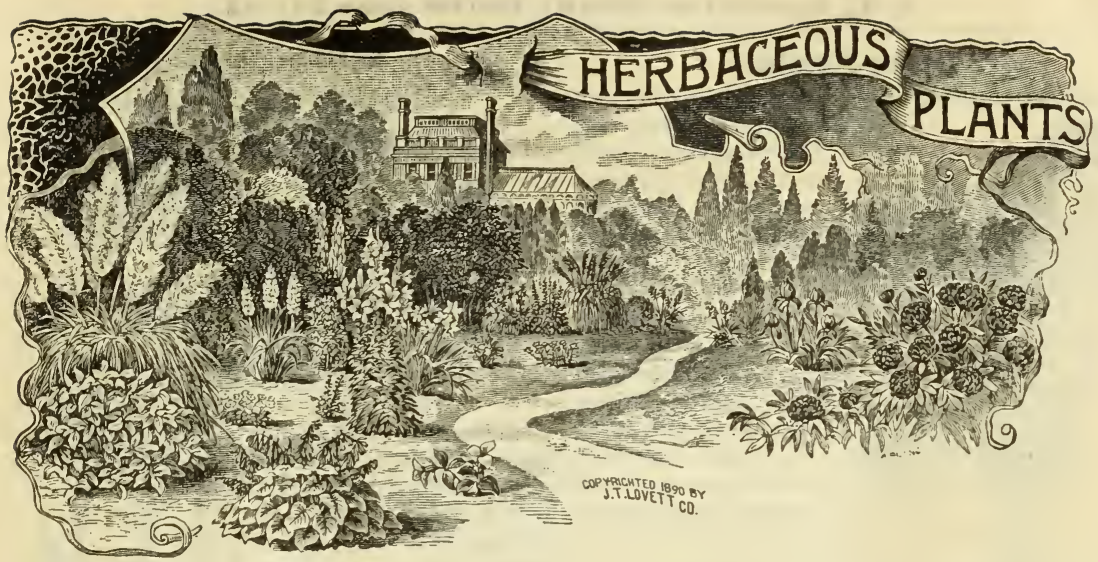

A most satisfartory class of plants, on account of their succeding under utter neglect, from the brilliancy and profusion of their bloom, and the fact that they continue in their beauty indefinitely-growing better from year to year. They are rapidly growing popular in America-supplanting Annual and "Bedding Plants"-as they have been for a long time in England-the only drawback to their general culture (the high prices at which most of them were held by nurserymen in the past) having been removed. For want of space we describe only a few of those we have to offer. For prices of others than those here named, in quantity, see Price List at end of Catalogue. We do not advise shipping these plants by freight; they should always be sent by express. Small plants, however, may be sent quite safely by mail.

Autumn is by far the best season of the year in which to put out Herbaceous Plants.

Price, each, 15c; doz., $81.50 ; 100, \$ 10.00$, ulews otherwise noted.

Any will be sent by mail, if desired, at each and dozen rates. Dozens will be supplied at ten times the price of ench. Large clumps selected at the Nurseries will be furnished at special rates.

ACHILLEA.

Double White Achillea or Millfoil.-

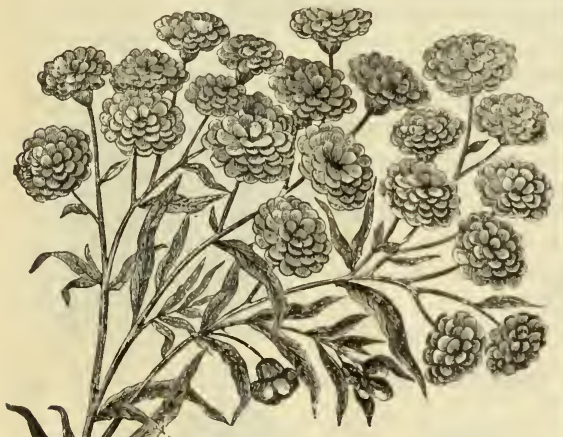

A hardy perennial of from 12 to 18 inches bearing profusely and continuously dense clusters of double pure white flowers from June to October. Fine for cemeteries. 15c.

Pearl Achillea.- New and a great improvement upon the preceding. The flowers are pure white, borne upon erect footstalks, and much resemble a Pompone Chrysanthemum. This is one of the finest flowers for cutting: succeeds everywhere. 25c.

\section{BOLTONIA.}

Boltonia latisquama or FALSE CHAMOMILE. -A little known but very valuable plant, growing 3 to 4 feet high and densely covered in August and September with delicately formed daisy-like flowers with clear pale lavender pink petals and golden centres. Not only exceedingly beautiful in the border but unsurpassed for bouquets, vases, etc. $25 \mathrm{c}$.
ANEMONE.

Japan Anemone. WHITE or HONORINE

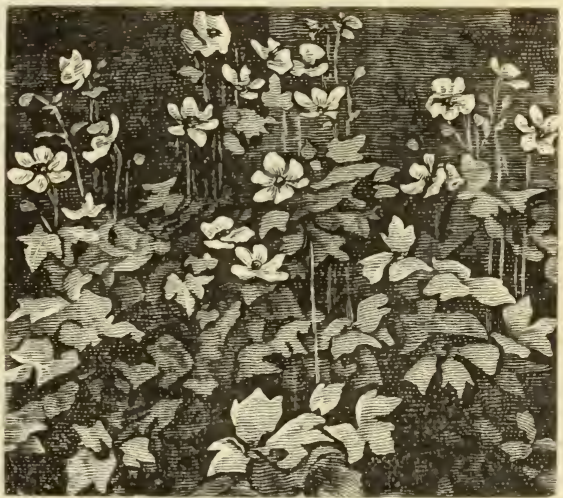

JOBERT and RED or RUBRA.-A beautiful plant some $2 \mathrm{ft}$ high, neat and compact in habit, with large and exceedingly beautiful flowers. The white variety is very pure, shell-like and chaste; the other is of a bright, rich, rosy red, semi-double and somewhat dwarfer than the white. Both have clear golden-yellow centres. They bloom freely from september to November and are exceedingly valuable and attractive, being very effective. $20 \mathrm{c}$.

\section{BUTTERCUP.}

Double Buttercup or Bachelor's Button (Ranunculus acris $f$. $p l$ ), $-\mathrm{A}$ bandsome border plant with finely cut. pretty foliage and large, very double, golden-yellow flowers, forming showy golden balls or buttons. Flowers profusely all summer. $15 \mathrm{c}$. 


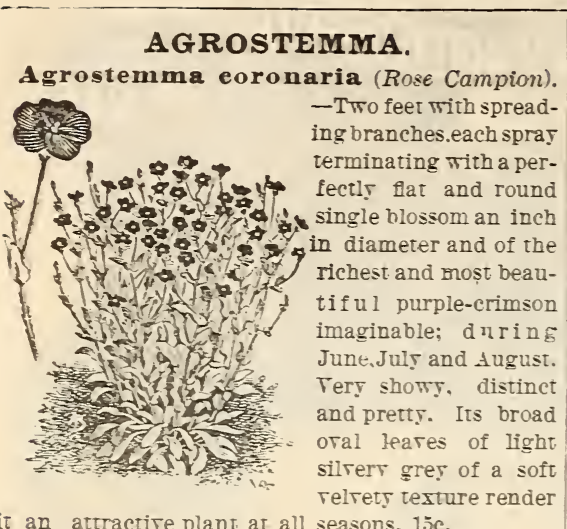

it an attractire plant at all seasons. $15 \mathrm{c}$.

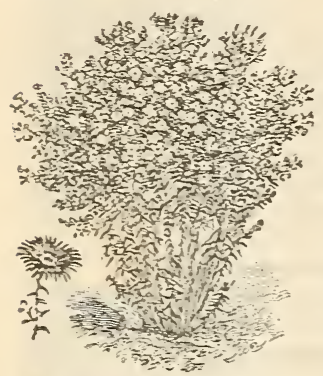

\section{ASTER.}

Yew England Rose Aster (A.tiora-angloca rosea).One of the finest of the Asters and strong, rigorous grower. Flowers in large clusters, of large size, deep roșpink color with orangerellow centre.

\section{ASTILBE.}

\section{Astilbe Japonica}

(Spirce Jayonica).i

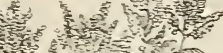

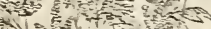

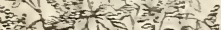

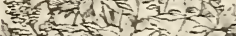

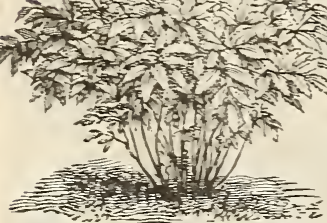

The dark green, cut leares form a handsome tuft. from which rise numerous, crowded,delicate, feathery panicles of small, silrer rwhite flowers.rendering it rers elegant and usefui. both as a border plant and for cut flowers. It is of special ralue for forcing under glass, is largely used by florists for that purpose, and makes an excellent bouse plant. 20c.

\section{BLEEDING HEART.}

Seal Flower (Dicentra or Diclytra specta-

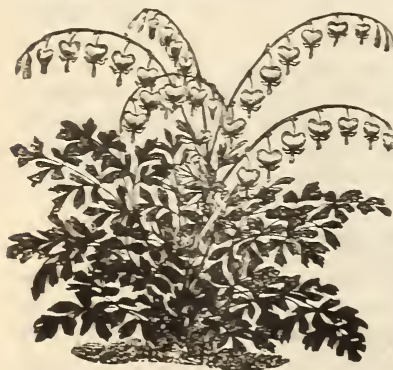
bitis)-The showy, beartof rosy crimson and $\mathrm{sil}$ rer $y$ white of this plant are borne on a graceful drooping raceme a foot or more in length. Is superb for the garden and perfectly hardy er-

erswbere. Well known and very popular. 20c.
COREOPSIS.

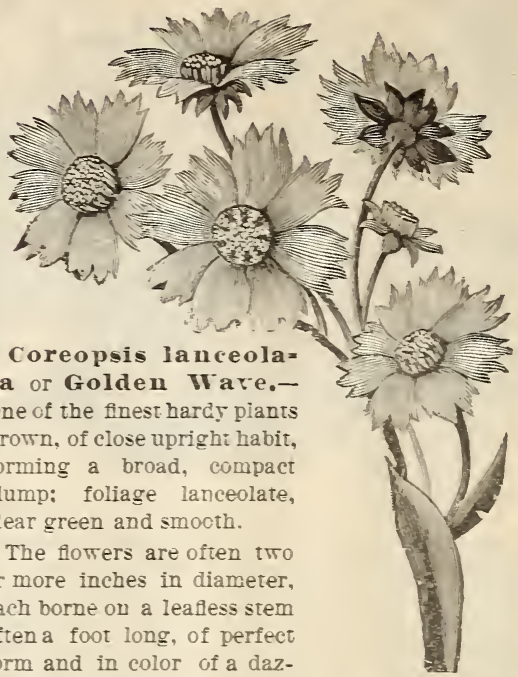

zling golden-rellow, riraling in intensity of color any other golden forrer in cuitiration. A monder. fully profuse bloomer and most excellent for bouquets. $A$ bed of it in full bloom is a sight indeed.

\section{CONVALLERIA.}

Lily of the Valley (C. majalis).-The well. Lnow a beautiful plant blooming early in spring. Small.bellshaped white nowers, deliciously fragtant and rers graceful. Plant in rich soil and in partial shade. Largely used for blooming under glass in winter, for which purpose it is exquisite. 10c.

DAISY.

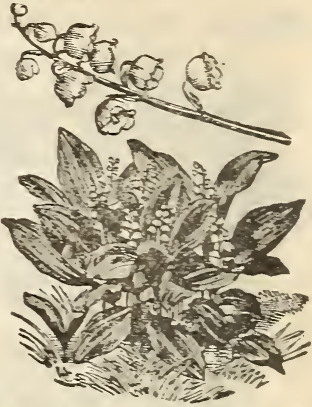

Double Englisla Daisies. Srow ano

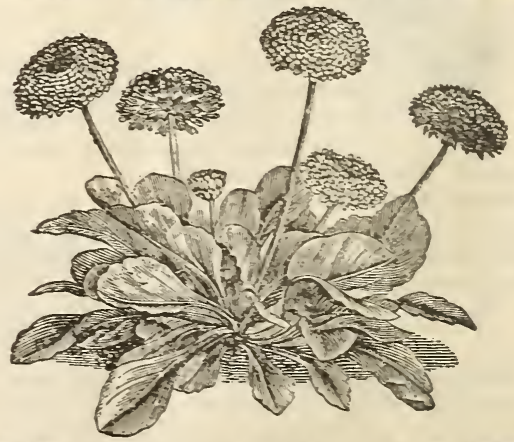

LOSGFELLOW.-Charming little border or edging plants with handsome double flowers in spring. The former is pure white, the latter rose. These are the well-known English daisies; not entirely hardy in $\Delta$ merica. Large strong plants. ?oc. 


\section{CHRISTMAS ROSE.}

Helleborus niger.-Evergreen perennial, about one foot in height, with very beautiful, pure white flowers in early spring, from one to two inches in diameter. A hardy and effective plant. As yet not appreciated to the extent its beauty merits. $20 \mathrm{c}$.

\section{CONE FLOWER.}

Rudbeckia maxima.-A tall, stately plant with handsome, large, glaucous leaves and immense flowers, clear, bright yellow with chocolate centre. Striking and effective for planting among shrubbery or at the back of a border. 25c.

\section{DAY LILY.}

Blue Day Lily (Funkia ovata).-A superb

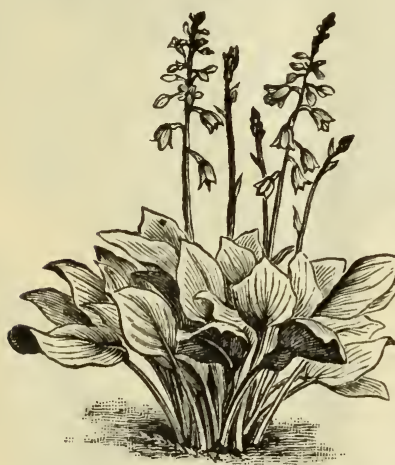

autumnflower having broad, dark green, glossy foliage and la rge, funnel - shaped, pale blue flowers in June. A vigorous grower and excellent border plant of easy culture. Fine for planting in clumps on the lawn, in the border, or on margins of shrubberies, where its hancisome follage proves very attractive.

Double Day Lily (Hemerocallis fulva fl. $p l$. ). -Large, very double, tawny-orange flowers. 25c.

Japan Day Lily ( $H$. Thunbergii). $-\mathrm{A}$ handsome species, blooming late in summer, and admirably adapted for border planting. The flowers are bright lemon-yellow, borne on long stems, very fragrant and sweet. $25 \mathrm{c}$.

Yellow Day Lily $(H$. flava). $-\mathrm{A}$ showy and vigorous species, with large, clear bright yellow, very fragrant flowers in summer.'

Variegated-leaved Day Lily ( $F$. lancifolia undulita variegata).-Foliage broadly and distinctly margined and variegated with pure white: very showy and attractive. 25c.

White Day Lily or Corfu Lily ( $F$. subcor-

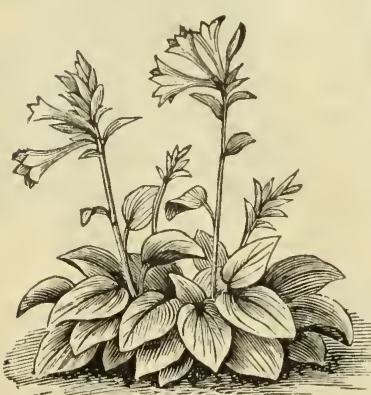

legant fragance. Foliage charming.

\section{GRASSES.}

Erianthus Ravan næ.--A flne foliaged grass somewhat resembling the Pampas Grass and grow's to a height of from 6 to 9 feet. Blooms very abundantly and is excellent for the drcoration of lawns or borders. $20 \mathrm{c}$.

Eulalia gracillima "uivittata. - A beautiful variety of Eulalias recently introduced; perfectly hardy and very desirable for decorative purposes. The foliage is exceedingly graceful in habit, narrow, a delicate green with. sil. very white midrib. Fine for vases, tubs or planting on the lawn.

Eulalia Japonica variegata.-One of the handsomest and most valuable of Ornamental Grasses. The long, narrow leaf-blades are bordered on either side and are striped with broad rands of pure white, while its habit is graceful and feathery. It attains a height of from 4 to 6 feet, is entirely hardy and in autumn throws up great numbers of tufts or plumes, like Pampas Grass, which, when ripe, resembles ostrich feathers to a degree and are useful for decr,rative purposes. Either as a single sperimen upon a lawn or in groups it is most effectua! and attractive.

Eulatia Japonica zebrina. $-A$ handsome

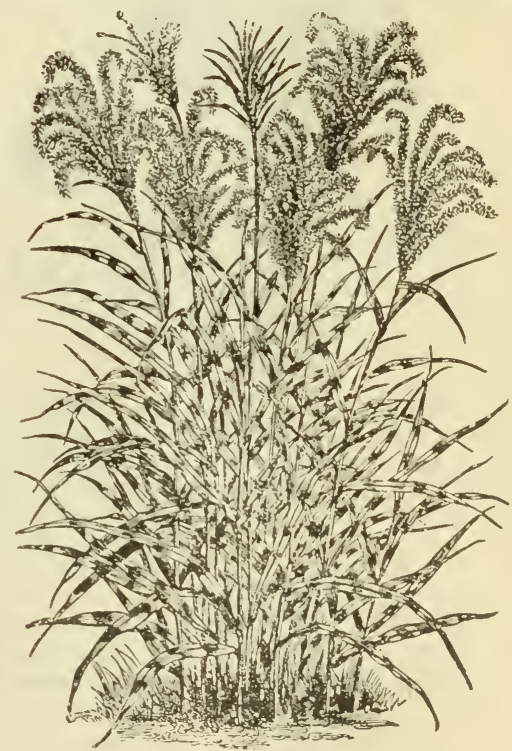

variegated form differing from Eula!ia Japonica variegata in having its markings or variegation, which are yellow instead of white as in the other, in bands across the leaf at regular intervals, instead of longitudinally. The expanded flower spikes are the same. At the North it should be slightly protected in winter as it is apt to be injured. As beautiful and valuable as it is curious and interesting. 


\section{FLOWERING SPURGE.}

Euphorbia corollata.-A handsome plant with beautiful pure white flowers, borne spray-like on tall branches. The plant has light green foliage and the whole is exceedingly ornamental. The flowers are well adapted for bouquets and vases and furnish a profusion of bloom from July to October. It is often known as the White Forget-me-not. $20 \mathrm{c}$.

FOXGLOVE.
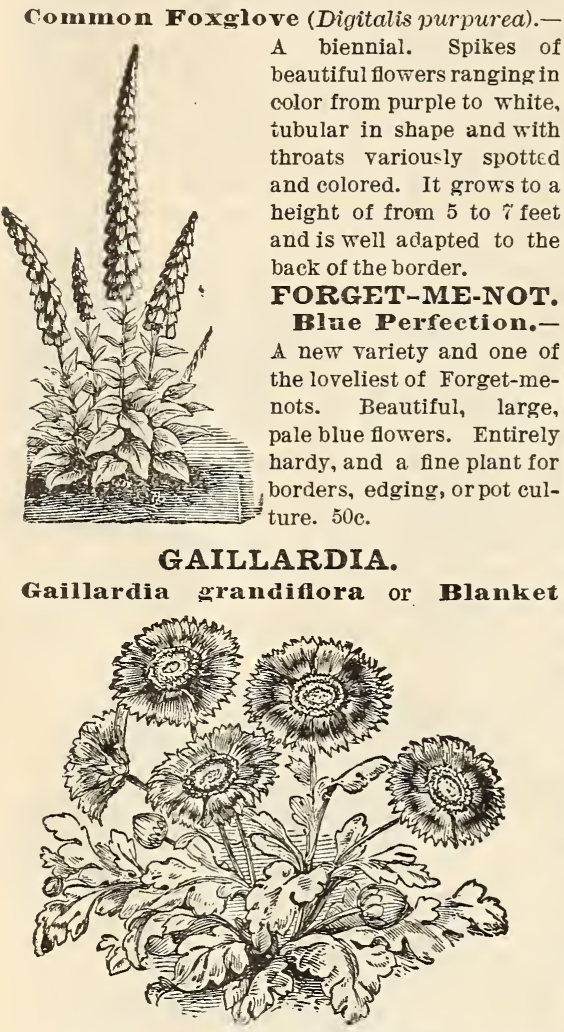

Flower.-A most brilliant and showy flower, deepest red with maroon centre and tips of petals orange, rendering it by far the finest of all the Gaillardias. It blooms profusely from June untri the ground freezes, and succeeds upon all soils,

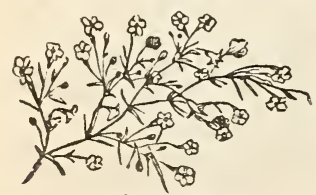
enduring with patience any amount of ill-treatment and neglect. Valuable also for cutting. 20c. Gypsophilla.

Gyps o ph i 11 a

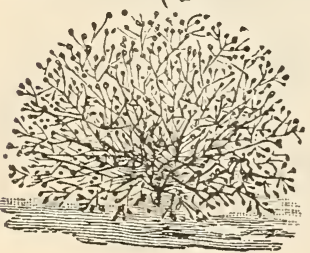
repens. - A handsome, dwarf, creeping plant a dmira bly adapted for rockwork. Pretty, pqle green foliage and l'ght pink or reddish flowers in abundance all summer. 20c.

\section{GERANIUM.}

Sanguineum.A handsome freeblooming border plant with ornamental foliage and large crimson flowers produced in abundance all summen

HESPERIS.

Hesperis matromalis (Rocket), PCRPLE, WHITE. - 3 feet; rarieties producing tall spires of purplish-red or white flowers in June. Suc-

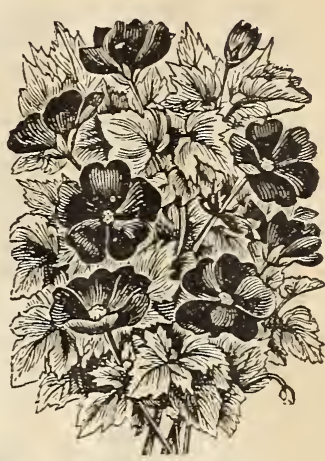
ceeds everywhere and is of the easiest culture.

\section{HOLLYHOCK.}

Double.-Red, White, Yellow, ScaRLET, PiNK. Well known, hardy and tall showy plants; a dmirably adapted for grouping upon the lawn, planting among shrubbery or at the back of borders. I m mense spikes of showy flowers, perfect in form, and $\mathrm{r}$ a $\mathrm{n} \mathrm{g}$ i $\mathrm{ng}$ through all shades of the colors above named. We offer a fine assortment of the flnest sorts. 20c.

HARE BELL.

Campanula Carpathica.-A heautiful little hardy plant with dentated, ovate foliage of dark green, and bell-shaped flowers of deep blue color. A strong grower of compact habit and a profuse bloomer. 20c.

\section{LARKSPUR.} Blue Larkspur (Delyhinium formosum).-The common blue Larkspur of our grand mothers. Grows about 3 feet tall with long spikes of most intense indigo-blue flowers an inch across, all summer. Unsurpassed for rich color and has few equals.

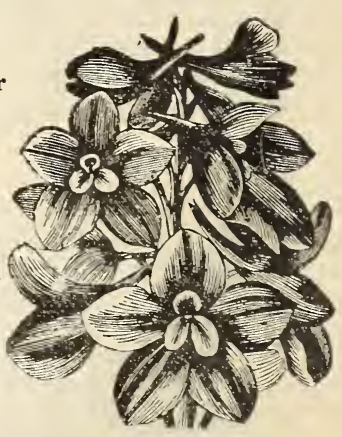

MEADOW BEAUTY.

F hexia Virginica.-A charming little tuberous-rooted plant of easy culture, ard one of the most beautiful of our late summer flowers. Large, showy, rosy-purple flowers with bright yellow stamens. Very effective in masses. 20c. 
IRIS.

Japan Iris (I. Kaempferi) - The most beautiful

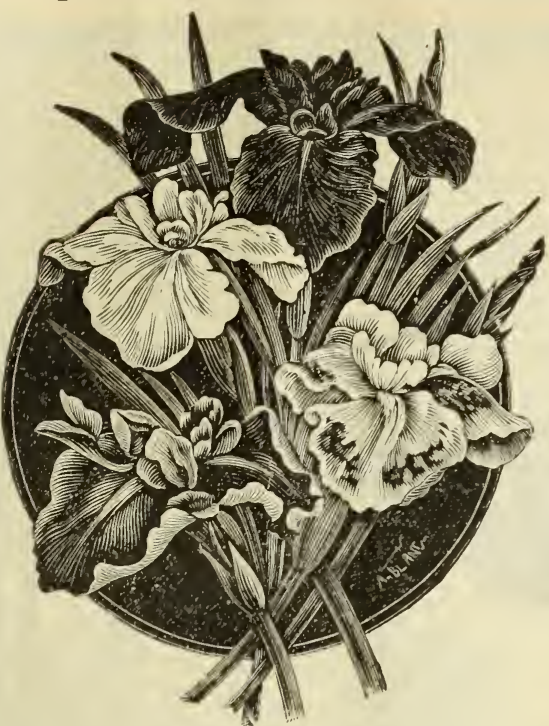

of all the Iris family. Entirely hardy and succeeds best In a moist soil. The flowers are very large and handsome and differ in form from ordinary kinds, being broad and flat; present a remarkable variety of color, from pure white and ranging through the various shades of blue, purple and violet, with occasional markings of yellow and white. It is quite distinct from all the other species and is a valuable acquisition. Mixed colors.

German Iris ( $I$. Germanica), - We offer a

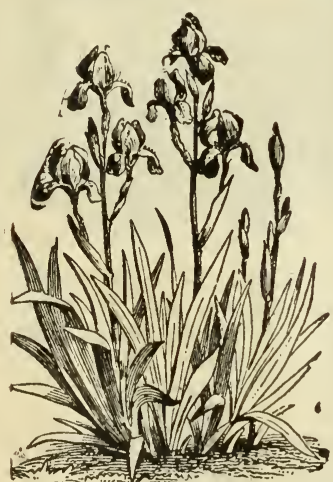

choice assortment of the flnest and best named varieties such as :

A UREA, rich golden yellow. Celeste, delicate, pale lavender. Dovna Maria, white, shaded with lavender. IMOGENE WARE, clear, delicate lavender. LA TENDRE, pale violet or lavender; very flne. MAD. CHEREA $\mathrm{U}$, white veined and feathered violet; very showy. PALLIDA SPECIOSA, pale indigo-blue. REBECCA, buff and maroon, shaded yellow. SAMPSON, rich golden-yellow and maroon, veined white. SАРPно, blue and indigo; fine.

Iris cristata. - A beautiful species with short flower-stalks and blooming early. The flowers are pale blue, shadea. fringed and dotted with orangeyellow, producing a charming effect.

Florentine Iris ( $I$. Florentina).-Produces large flowers in great abundance. White tinged and veined with blue, changing later to a bright creamy color. Fragrant.

Siberian Iris ( $I$. Siberica).-A tall, handsome species with blue flowers, delicately veined and spotted with yellow. Foliage narrow, a free bloomer and fine for borders.

LOBELIA.

Cardinal Fiower or Wild Scarlet Sage ( $L$, cardinalis). - A showy and hardy border plant, one of the best in cultivation. The flowers appear in late summer, in dense spikes of a vivid scarlet or cardinal color. Said to be the most brilliant and vivid in color of all flowers in existence. producing a

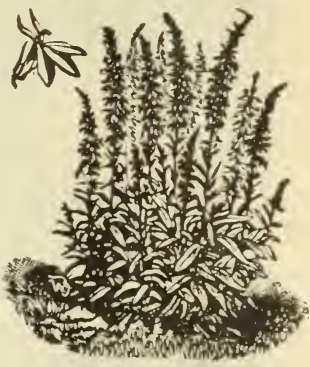

most striking effect when contrasted with the dark green of neighboring foliage.

IMOSS PINK.

Plilox subulata. PINK, White.-A dwarf

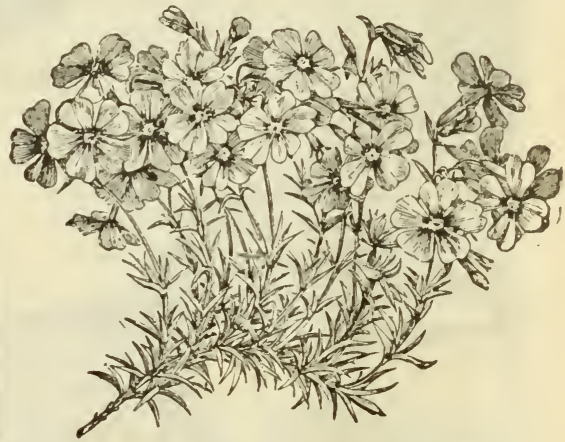

plant forming a dense mat, and is completely covered in early spring with beautiful bright pink flowers. The white form is the same in all but color of bloom. Unexcelled for bedding or carpeting.

\section{MOUNTAIN FLEECE.}

Polygonum amplexicaule varoxyphyl. $1 \mathbf{u m}$.- One of the best hardy herbaceous plants that has been introduced for some time. The root throws up a compact mass of stalks from 3 to 4 feet high, well furnished with foliage to the ground. The flowers, which are borne in large panicles, are white and small, but very numerous, and take on a pink tinge with age on the approach of frost. They bloom from early September to frost and are very fragrant The great white masses of bloom, at a distance, may well be likened to fleecy clouds.

\section{POPPY.}

Oriental Poppy (Papaver orientale).-Very handsome and showy. Flowers of immense size, of dazzling crimson color, with a large black blotch at the base of each petal. Leaves, dark green, flnely cut and like ferns. A strikingly effective plant for use in the border.

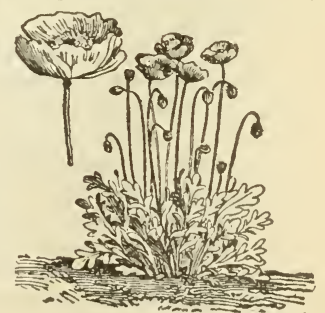


PRIMROSE.

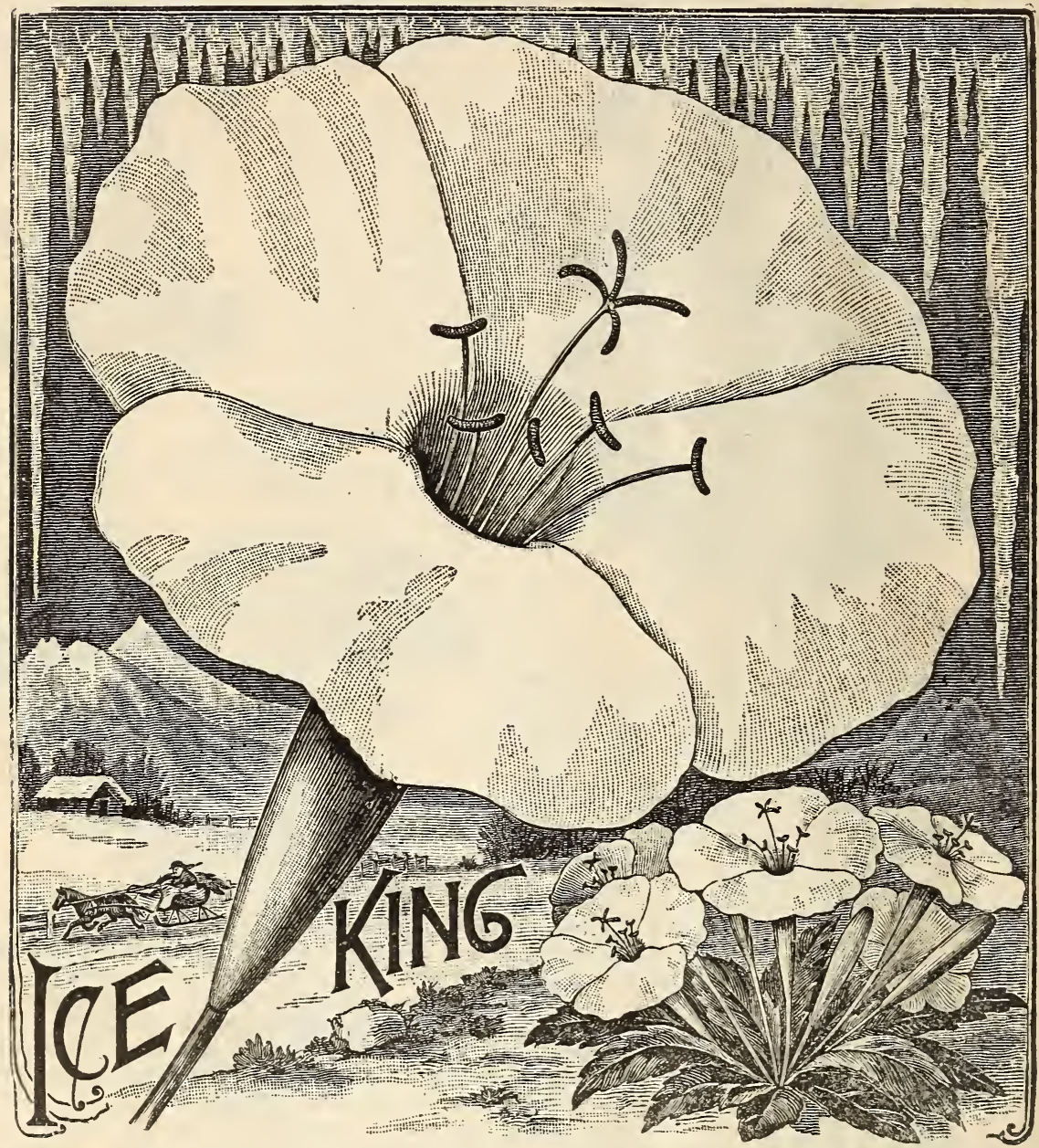

Ice King.-This new everblooming Primrose is of remarkable hardihood, a wonderful flower in many ways. Its home being Montana, that land of intense cold in winter and long drought in summer, it will endure perfectly a temperature of $40^{\circ}$ below zero and continues to grow and bloom freely during the heat of summer in the most unfavorable locations; places where almost every other herbaceous plant would not only cease to bloom but perish. The plant has ornamental cut foliage and forms dense tufts and throws up its marvelous flowers every day, from early spring until late autumn, in the greatest profusion; 15 to 20 of its huge blossoms frequently being found upon the plant at one time. The flowers are from 4 to 5 inches in diameter, pearly white, delicately shaded rose and delightfully fragrant. They are borne high up above the plant, thus showing to best advantage. Altogether this is one of the most beautiful, novel, interesting and valuable plants we have ever come across and should, by all means, be in every collection. 25c.
Evening (Enothera speciosa)..--One of the finest plants for the border. Flowers large, white fading to pale rose, fragrant and of much beauty. Blooms profusely from May to September. 20c.

English (Primula acaulis rubra).-The popular European primrose, blooming abundantly in spring; flowers large and of a beautiful crimson. We suggest its use in well drained borders and rock-work. $20 \mathrm{c}$.

Ware's Hybrids. -An exceedingly fine strain of large size which we can confldently recommend. These are sure to give

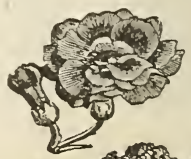
15

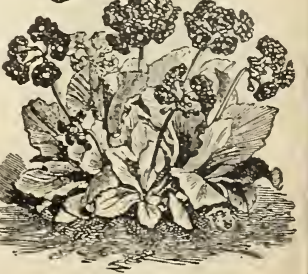
atisfaction in any suitable situation. $40 \mathrm{c}$. (52) 


\section{PHLOX.}

Perennial. - The improvement that has been

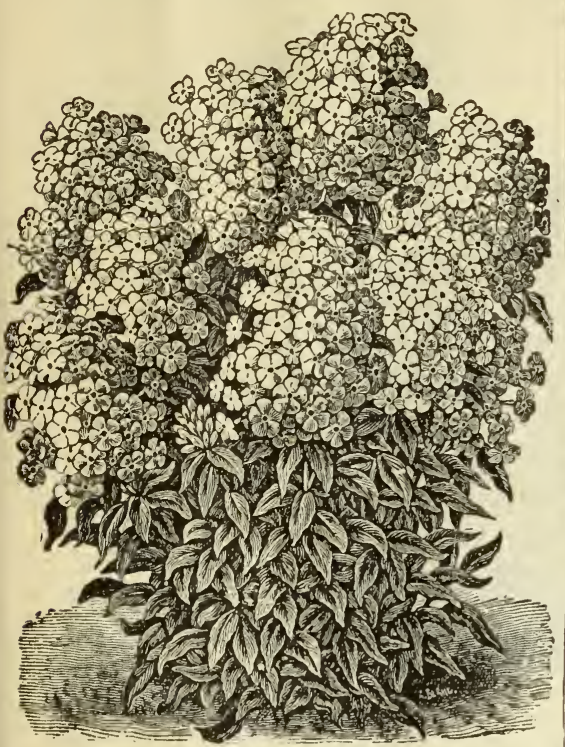

made in Hardy Garden or Perennial Phox of recent years is truly wonderful. The varieties instead of being a lot of tall, naked stems with small tufts of bloom at the top for a little while in midsummer as of old, are dwarf and stocky with flower heads 8 to 10 inches long and 6 to 8 inches in diameter (see cut) of greatest brilliancy and purity of color, and are produced from June until frost. We give the names of a few of them with brief notes:

AMABILIS, white, penciled and shaded with lilac, changing to rosy-lilac. Compact, odd, distinct and handsome. BALL OF FIRE, one of the most charming of all varieties. Bright crimson. ENDALE, rosy-lilac, very large. FORWARD, white, pink eye. FLIzA BORZNER, bright peach with crimson eye. GloRIE MaSSEIFrs, white, with pink eye and tubes, large panicles, late, exquisite. INDEPENDENCE, pure snowy-white; profuse, compact, very flne. JoAN of ARC, dwarf, one foot high. Large panicles of pure white. LA Crorx, strong grower, lilac shaded red, petals over-lapping and curled. LE COMPTE, bright lilac, with large, faint light eye, targe panicles. LE RICERON, rosy lilac shaded white. LoTHAIR, bright flame color, creamy €ye, large. MAD. Louise, rosy-crimson, bright vermilion eye. MISs LINGARD, white, suffused rays of delicate lavender from eye and oper stem. PEACH Blossom, pure peach with white eye, fine. Princess LoரISE, white with pink eye. REve D'OR, rose-peach, carmine eye. ROBIN HOOD, white clouded purple with carmine eye, very showy. Rosy GEM, very large, violet-rose, passing to clear pink. SNow QuEEN, pure white, dwarf, profuse, beautiful. STAR of LYON, pure white, with distinct rosy-lilac eye, dwarf, early and profuse, one of the best. VULCAN, erimson-lilac, showy. WM. ROBINSON, plum-crimson, brilliant.

Dwarf ( $P$. amona).--Seldom exceeding 6 inches; dense clusters of rosy-pink flowers. $25 \mathrm{c}$.

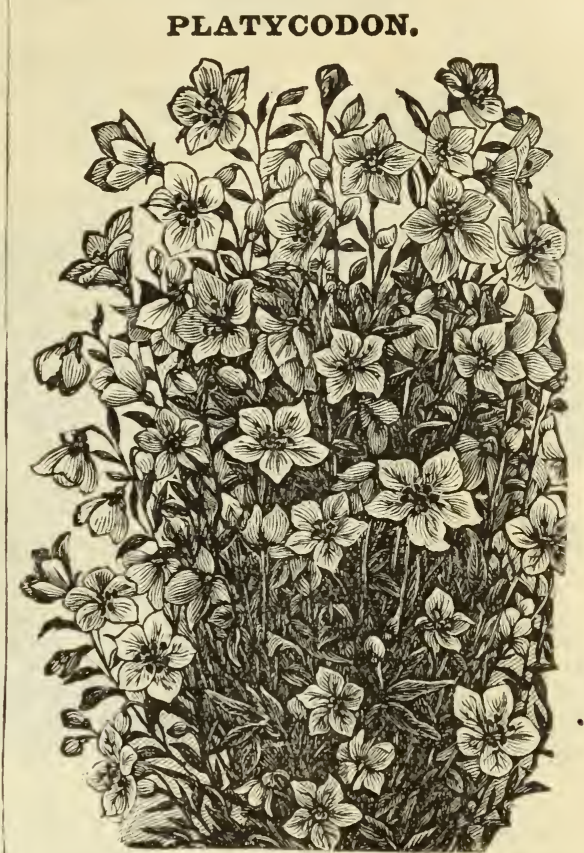

Platycodon grandiflorum.-BLUE, WHITE。 A grand flower indeed, attains a height of 2 to

3 feet and covered with a mass of showy, starshaped flowers three inches across, of greatest beauty. In color it is deepest indigo-blue to pure white and all intermediate shades, and continues in flower the entire summer, splendid for bouquets as well as the lawn. A solid bed of it is simply charming. Should be

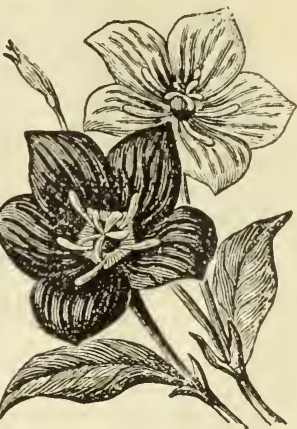
included in all collections.

Grandiflorum 1. pl. or Double flowering.-DOCBLE BLUE AND WHITE. Double flowering varieties of the above.

\section{RAGGED ROBIN.}

Lyehnis viscaria fl. pl.-A magniflcent perennial with thickly tufted foliage and very double flowers in dense spikes and on long stems, beautiful rosy-red and exceedingly fragrant. Very fine

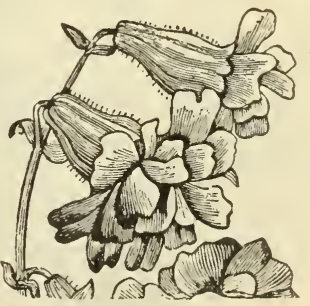

\section{PLUMBAGO.}

Larpentæ. $-A$ beautiful plant of dense, spreading habit with deep azure-blue flowers from July to November in greatest profusion. 


\section{J. T. Lovett Co.-Hardy Herbaceous Fiants.}

\section{PIEONIA.}

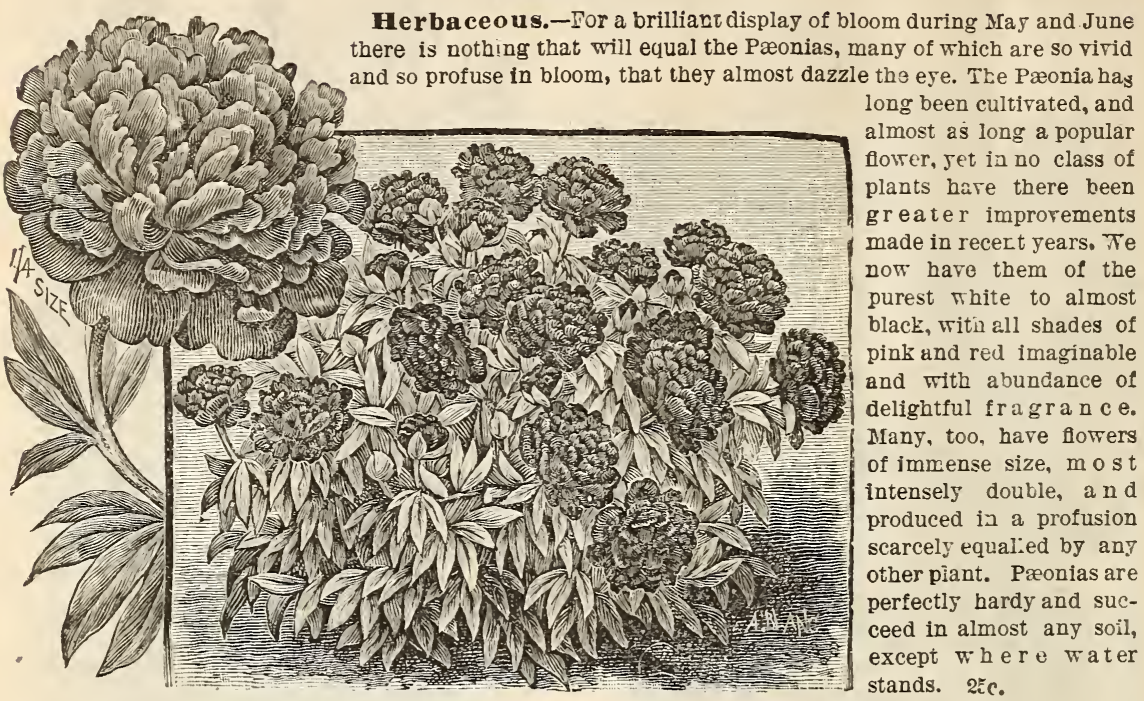

PANSY.

Large Fnglish.-This lovely flower is too

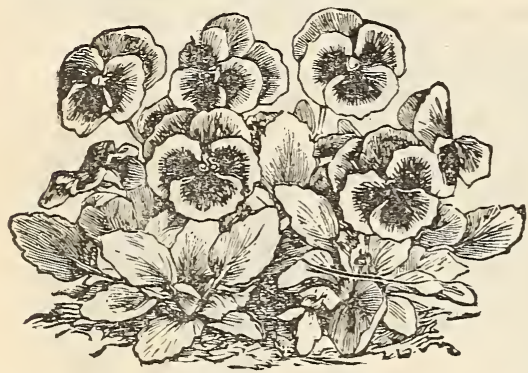

Well-known to need any description. Favorites with everyone, they charm with their rich and graceful beauty. Our collection embraces seedlings from the very flnest strains in a great variety of color and very large flowers. Requires protection in winter. 15c.

\section{SPIDERWORT.}

Widow's Tears (Tradescantia Virginica).

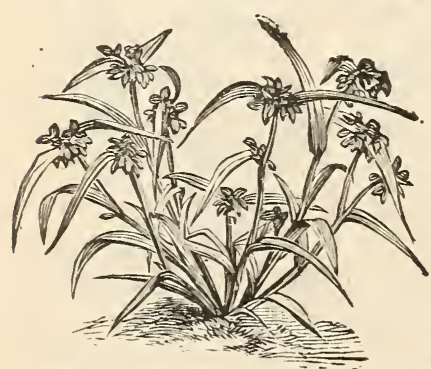

- Unsur passed for the deep violet blue of its soft velvety li ow ers, which are produced in clusters of three to five from May until winter. It grows a foot to two feet hish, the foliage resembling a strong-growing grass. Odd, interesting, pretty.
PERENNIAL PEA.

Scarlet. - A valuable ornamental climbing plant well suited for training to triils, cr covering Wais, stumps, ete. Flowers of a beautiful clear scarlet color, on long spikes, in great abundance neariy all sımmer. 25c.

White.-A variety of the above, with pure white flowers instead of red. Exceedingly valuable for cut flowers. $40 \mathrm{c}$.

\section{SUNFLOWER.}

Double Mardy or Dahlia (Helianthus mul-

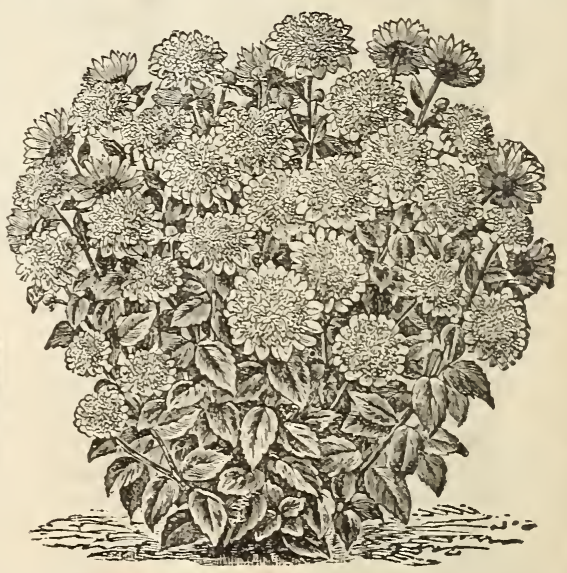

tiflorus fl. pl.).-Very shnwr and effective, attaining a height of three to four feet, of compact bushy habit and literally covered with very double, rich golden flowers, as large as fine Dahlias, from June until the ground freezes. It surpasses all other flowers of its color and remains in good condition a long time when cut. 


\section{SPIR EA.}

Double Dropwort (S. Filipendula $f l . p l$ ). -A

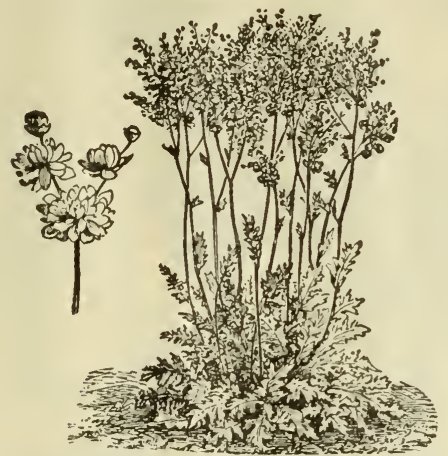

beautiful dwarf plant with fern-like, dark green follage and large, double, white flowers, faintly blushed with rose. $25 \mathrm{c}$.

Queen of the Prairie (S. lobata).-Tall showy plant, 5 to 6 feet, with large heads of dark rosy-red flowers in June and July. $20 \mathrm{c}$.

Spirae Ulmaria 1. pl.-A valuable hardy plant with double white flowers. Very desirable. 25c.

Spiraa Ulmaria variegata.-The variegated form of the above, exceedingly handsome, The follage is beautifully variegated with green and gold rendering it strikingly effective among other border plants. It is worthy of much greater attention than it now receives. $25 \mathrm{c}$.

Spiraea venusta.-One of the flnest; beautiful rose-colored flowers in feathery sprays or plumes, decidedly graceful and highly ornamental. $25 \mathrm{c}$.

\section{SCOTCH PINK.}

Rose-Fringed Scotch Pink (Dianthus

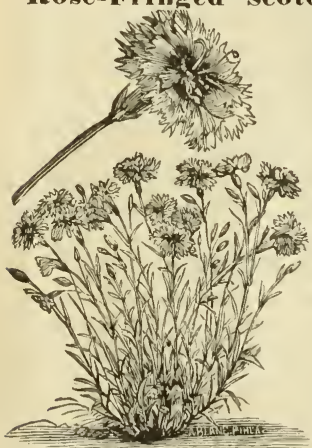

plumarious roseus $p l)$. - A n old and valable variety, blooming with the greatest profusion in May and June. Flowers are clear, rosy-pink, very double, e legantly fringed and fragrant. Plant compact and very hardy.Fspecially valuable for borders and cutting. It has the true clove scent of the Carnation but is perfectly hardy, needing no protection whatever in winter.

\section{VERONICA.}

Veronica amathysina.-A hardy perennial of dwarf habit. Flowers amethysist-blue; in June.

Veronica incana - Small spikes of deep blue flowers, foliage light gray. A beautiful little plant for rockeries, etc.

\section{TUNICA.}

Tunica saxi fraga.-A handsome dwarf little plant, suitable for rock-work or edging, with delicate foliage and small, pale-rose colored flowers, borne in great profusion all summer.

\section{SWEET WILLIAM.}

Dianthus barbatus. - The improvement that has been made during recent years in this old favorite flower is truly surprising. The flowers are not only larger and more brilliant, but the clusers are finer and are produced more freely, and of every imaginable color from pink to deepest crimson during June and July. Very fragrant and especial-

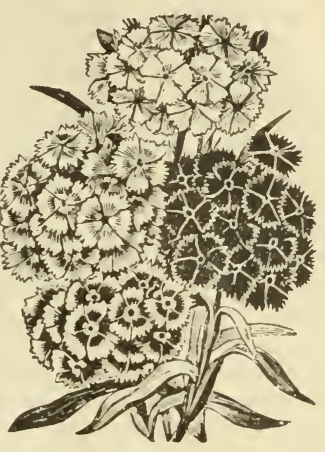
ly valuable for cutting.

\section{SEDUM.}

Sedum spectabile.-A handsome showy plant both in foliage and bloom. The leaves are oval and broad, pale green in color; flowers rose-colored and borne in large clusters. Blooms in summer. Forms large clumps and is very tenacious of life. This is an improved form of what used to be known as "live forever."

\section{VIOLET.}

Alpine violet ( Viola cornuta). BLEE, White. Large, pale blue,delightfully f ragr an t flowers, which are produced in great profusion from May until September. Foliage dark glossy green and attractive. The white form is the same except that the flowers are pure white.

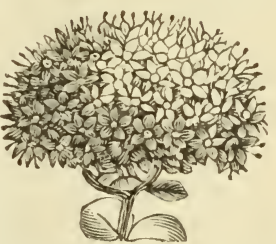

Iarie Louise $(\boldsymbol{V}$. odorata),-Large, double

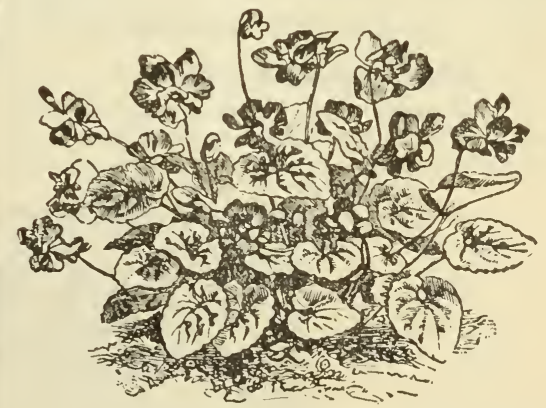

flowers of deep blue and of the most delightful fragrance. Especially valuable for blooming in winter under zlass. Clumps by express, $25 \mathrm{c}$. 
TURKEY'S BEARD.

Xerophyllumg; asphodeloides.-This showy plant is not often seen in gardens though it well deserves a prominent place in the border. Considerable attention, however, is now being attracted to it in England, and when its merits are better known it will deservedly become popular. It is a perfectly hardy perennial with evergreen foliage, and when in bloom presents a showy, tropical appearance. The large flower heads or clusters are from six to ten inches long by three inches in diameter, pure white, and are burne on stalks of from two to four feet in height, single clumps producing as many as eight of these heads. They remain in good condition for a long time and are excellent for cutting. Its evergreen and graceful foliage, large flower heads, and generai showy appearance render this a beautiful and exceedingly raluable plant. We quote the following from the London Garden:

"Turkey's Beard (Xerophyllum asphodeloides) is one of those oldfashioned plants that are rare in gardens. Two splendid misses were $\in \mathrm{X}$ hibited by Lord Walsingham at the

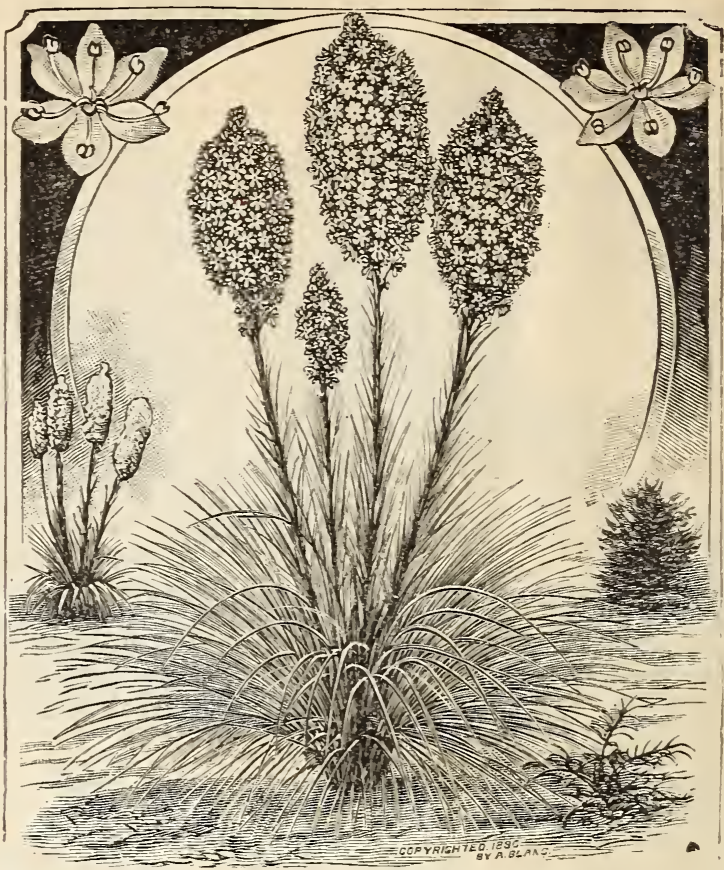
recent Royal Botanic show, and were the prettiest things there among hardy flowers." 20c.

HARDY CANDYTUFT.

Iberic sempervirens. A handsome shrub-

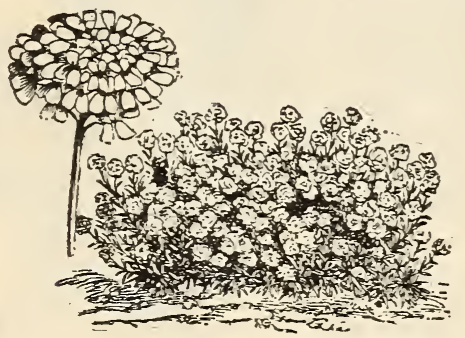

by.plant with dark, dwarf, evergreen foliage; flowers pure white, produced in close heads and completely covering the plant with bloom in spring. Very fine and desirable either for outdoor planting or for forcing. 20c.

\section{CHRYSANTHEMUM.}

Uliginosum. A flne decorative plant and one of the best bardy perennials, producing flowers in great abundance from September to hard frost. These flowers are large and of a lovely pure white color with yellow centres, exceedingly beautiful and effective for border planting and fine for cutting. $20 \mathrm{c}$.

\section{DESMODIUM.}

Penduliflorum. A beautiful shrubby plant with pretty foliage, and in autumn bright purple flowers appear at the axils of the leaves and remain until frost, rendering the plant most charmingly attractive. Of rather pendulous he bit and very handsome. It is so profuse in bloom that the plant, when in flower, resembles an immense buquet and is exceedingly airy and gruceful. Very desirable for border planting. 25̃c.

\section{HORNED POPPY.}

Glaucium luteum. One of the most showy and desirable species, remarkable for its beautiful Poppy-like plant and handsome yellow flowers. The leaves are deeply cut, fern-like, with a silvery-white or glaucous hue. The flowers are borne on tall. slender stems and of a bright golden yellow, very graceful and showy. It blooms profusely all summer and is a decidedly bandsome and ornamental plant both in foliage and bloom.

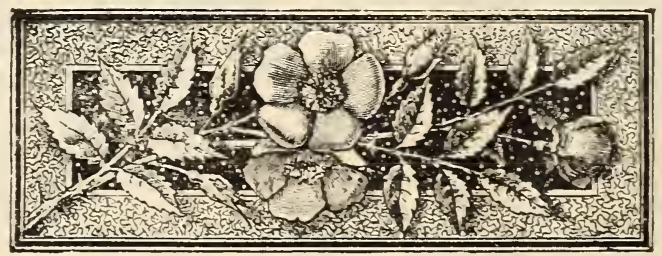

(56) 


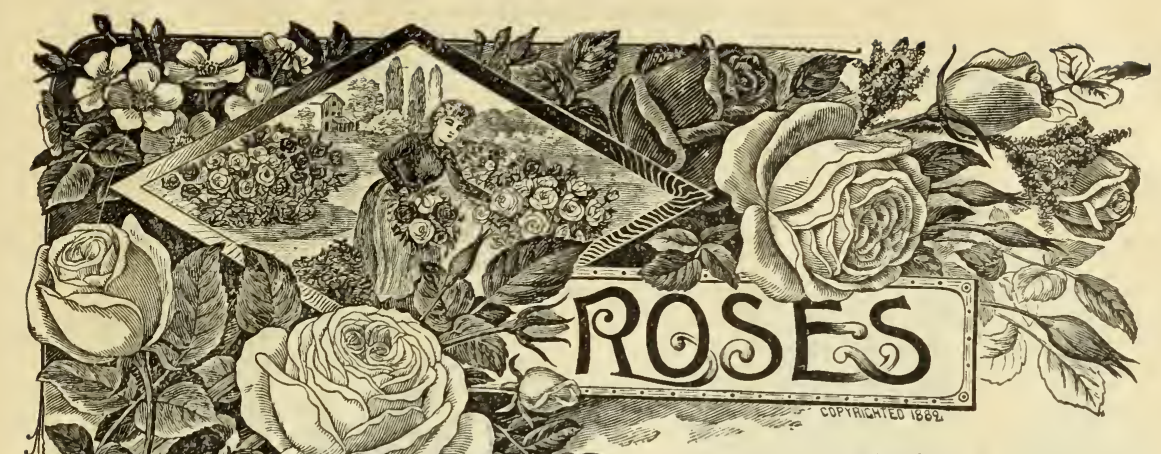

Prices quoted in black ty pe indicate that plants of that size will be furnished postpaid by mail.

Gen. Washington.-Large, flat and very double; brilliant, rosy crimson; a profuse bloomer.

Glorie Lyonnaise.-Clear, chrome yellow with rich, cream-colored border; large and fragrant. Jea u Liabaud. - Large, full and fragrant; very
dark, rich crimson. The richest and most brilliant HYBRID PERPETUAL.

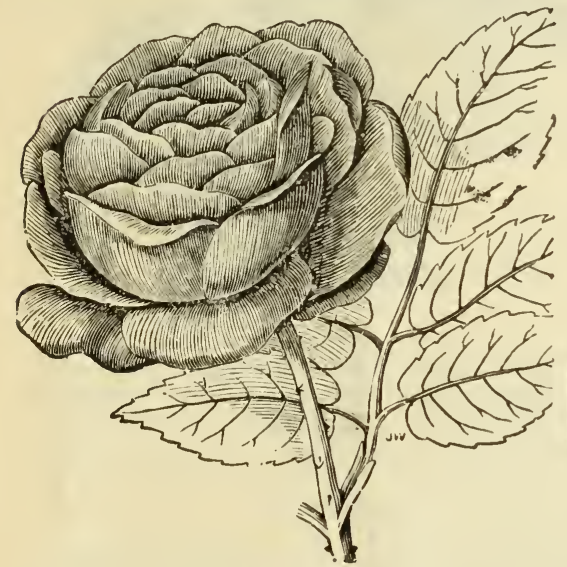
in color of all roses. Exquisitely beautiful.

John Iopper.-Brilliant deep crimson, very fragrant, large and full; a profuse bloomer.

Jules Margoten.-Bright cherry crimson, large and cup-shaped, fragrant and free.

La France.-Rich satiny peach, changing to deep rose, large, full, a constant hloomer, and the sweetest of all roses; the flnest hardy rose.

La Reine.--Dep rosy-lilac; large, a constant bloomer, and one of the hardiest.

Louis Van Ioutte.-Bright crimson, and one of the best of its color. Large, full and fragrant.

Iadame Charles Wood.-Dazzling crimson, of immense size, very free bloomer. Fragrant.

Madame Plantier.-Pure white, large, and very double; free bloomer; tine for cemetery planting.

Mad'lle Marie Rady.-Brilliant scarlet shaded with crimson; large and very full, fragrant.

Magna Charta.-Bright rose suffused with carmine, large and well-formed flowers; one of the most profuse bloomers and very fragrant.

Mervelle de Lyon.- Very large and full, of handsome cup form, delightfully perfumed; color, snowy-white, beautifully flushed with rose. A seedling of Baroness Rothschild, and magniflcent.

Paul Neyron.-Of immense size; color, a clear, deep rose, very double and full, finely perfumed. A free bloomer.

Perledes Blanches.-Of medium size; pure white; full, very double, and fragrant.

Prince Camillede Rohan.-Deep velvety crimson, large, very double, sweet; splendid.

Victor verdier.-Bright rose with crimson centre, a free bloomer, beautiful; extra flne.

\section{A NOVELTY INDEED.}

Mary Washington. - A hardy perpetual bloom. ing climber, bearing large, very donble, snow white fragrant roses, in great abundance, usually in large clusters, from June until frost. It is a vigorous and rapid grower and trails gracefully over whatever it may be placed against. This rose is interesting from the fact that it is the variety yet growing at Mount Vernon and which our first President named after his mother, Mary Washington. Aside from this, however, it is really a very valuable rose and will please every one with its old-fashioned charms. Strong plants, 30c. 


\section{EVERBLOOMING.}

Ea., 15 c. Large plants, ea., 25c.

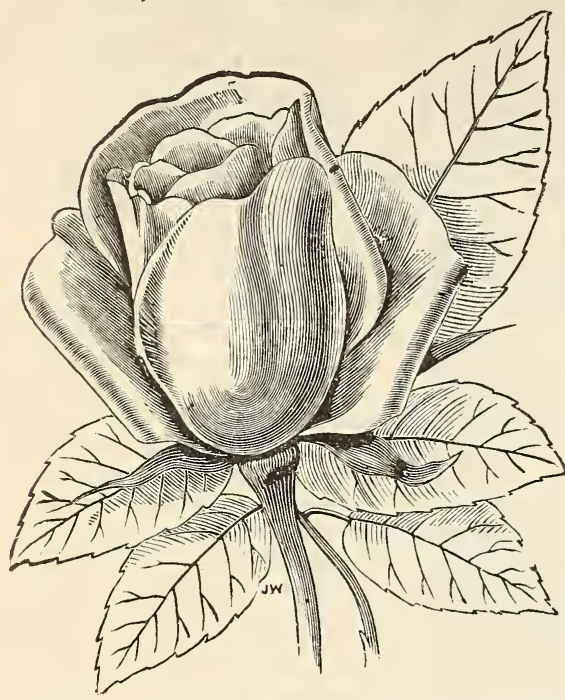

The Everblooming or Monthly roses belong mostly to the class known as Teas. They are admired for their delicacy of colcr, delightful fragrance and freedom of bloom, but require some protection during winter at the North. They come into flower the first season and bloom profusely during the summer and autumn. A small bed of Everblooming Roses will make a delightful spot on the lawn and furnish a fine supply of buds during the whole of the growing season.

Bon Silene.-Large and beautiful buds; rosy carmine; sometimes of a paler shade; very fragrant.

Duchesse de Brabant.-Rosy pink, petals edged with silver. A fine rose, and very sweet.

Hermosa.-Very double, blooms in clusters; color, a clear rose; a constant bloomer.

Marechal Niel. - The finest of all yellow roses. Very large, and highly perfumed; deep yellow.

Niphetos. - White, sometimes faintly tinged with pale, creamy yellow; buds large and long.

Perle des Jardins.-Very large, full and of fine form; pale golden yellow, delicately perfumed.

Papa Gontier.-Large and long, semi-double, very fragrant; deep rich carmine. Profuse.

Safra no.-Bright apricot yellow, very fragrant; splendid buds, and á free bloomer.

Sanæuinea. - Bright crimson; constant and profuse bloomer, and a fine bedder.

Sunset.-Similar in all respects to Perle des Jardins except in color, which is a rich amber.

Whe Bride.-Very large, double and full, fine form, very fragrant. Pure white. Profuse

\section{CIIMBING.}

Ea., 15c. Large, strong plants, ea., 25c.

These are especially valuable for training over ornamental arbors, trellises, pillars, verandahs, etc.; also for covering buildings, old trees, fences, or unsightly objects. All are perfectly hardy.

Baltimore Belle.-Pale blush,large, very double; flowers in clusters; one of the best.
Gem of the Prairies. - Bright crimson, large and double. Fragrant.

Greville or Seven Sisters.-Flowers in large clusters, of varied color from white to crimson.

Prairie Queen.-Bright rose, very large and frêe bloomer; extra fine; splendid; popular.

Pride of Washington (Anna Marie).Rosy carmine shaded to pink; very double and in large clusters; has few thorns.

\section{MOSS.}

Ea., 20c. Large, 2 yrs old, ea., 40c.

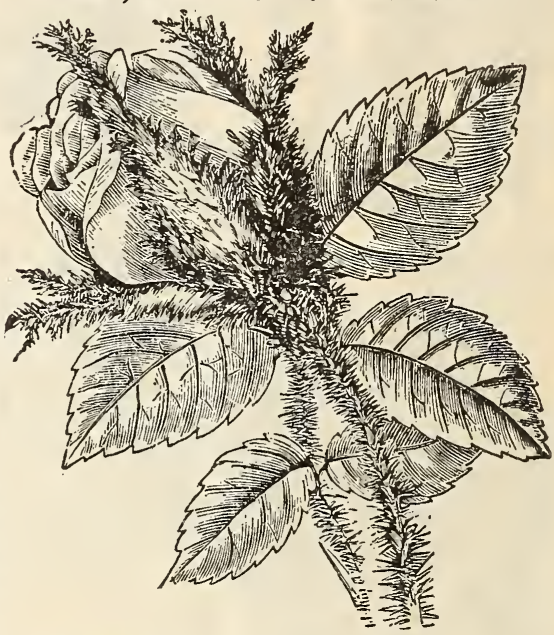

The Moss Rose still remains without a peer in refinement and picturesque beauty. The elegance of her opening buds, half wrapped in their mossy envelope, will remain, through all ages, a chosen interpreter of the sentiments of youth and beauty. They are all entirely hardy, bloom in June, and occasionally through the summer.

Henry Martin.-Rich rosy pink; finely massed, large and full; fragrant.

Perpetual White.-White in clusters, very mossy; an autumn bloomer; very valuable.

Princess A delaide.-Bright rosy pink, large, very double, strong grower and free bloomer; fine.

\section{JAPAN ROSES.}

VIadame Geo. Hruant.-The first of a new class of hybrid roses produced by erossing the single red Rugosa with the Sombreuil Tea rose. It is a very attractive plant, with foliage of the Rugosa type but the young shoots are purple. It blooms profusely and continuously throughout the whole season and its fiowers are exceedingly beautiful, and produced in graceful clusters of from six to twelve blooms each, large, half-full, long and pointed, like Niphetos, of pure white color and zery iragrant. Ea., 50c. Large, 2 yrs. ea., ric.

Fosa IR uosa or Japan Rose.-Of recent introduction from Japan. It has abundant, large, vigorous, handsome dark green glossy foliage of great richness and beauty; perfectly hardy and grows from four to five feet high. The flowers which are produced freely all summer are single, and with ave vetals. The color is a rich, rosy crimson, enhanced in beauty by the numerous stamens. The flowers are succeeded by large clusters of hright erimson-scarlet fruit, nearly two inches in diameter. It is admirably adapted for planting on the lawn, either singly or in groups. This great acquisition is exceeded in beauty by very few plants of any sort. Ea., $25 \mathbf{c}_{\text {. }}$; large, 35c. 


\section{PRICE LIST}

ORNAMENTAL TREES AND PLANTS.

All large sizes should be shipped by freight, as charges by transportation are much less than by express. Dozens will be supplied at ten times the price for each. Still larger sizes than those quoted can be had at the nurseries as special prices. The prices include packing and cartage; the purchaser paying transportation eharges.

DECIDUOUS TREES.

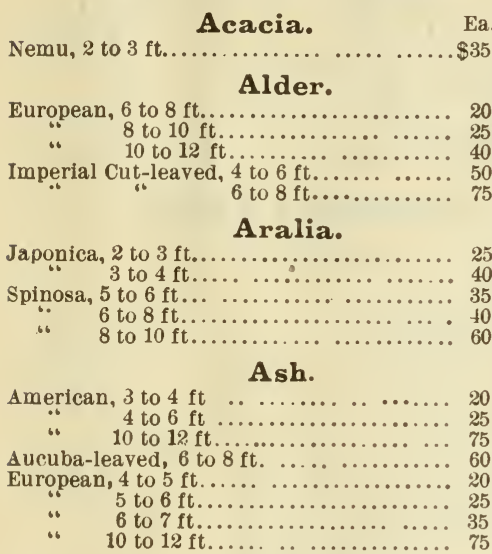

\section{Beech.}

Fern-leaved, 5 to $6 \mathrm{ft} . \ldots \ldots \ldots \ldots \ldots \ldots \ldots 200$ Rivers' Purple-leaved, 2 to $3 \mathrm{ft} . . . \ldots \ldots \ldots . . . .50$ 3 to $4 \mathrm{ft} \ldots \ldots \ldots \ldots, 75$ 4 to $5 \mathrm{ft} . \ldots \ldots \ldots . .100$ 5 to $6 \mathrm{ft} . \ldots \ldots \ldots \ldots 150$

\section{Birch.}

Cut-leaved Weeping, 4 to $6 \mathrm{ft} . . . \ldots \ldots \ldots . . .50$ Scotch or White, 4 to 6 to $8 \mathrm{ft} \ldots \ldots \ldots \ldots \ldots \ldots \ldots$. $\ldots$. 75

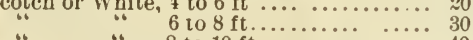
8 to $10 \mathrm{ft} . \ldots \ldots \ldots \ldots \ldots, 40$ Young's Weeping, 5 to $6 \mathrm{ft} \ldots \ldots \ldots \ldots . . . . .100$

\section{Catalpa.}

Bungel, standard, 2 and 3 yr. heads......1 25 Speciosa, 2 to $3 \mathrm{ft} \ldots \ldots \ldots \ldots \ldots \ldots \ldots \ldots . . . \ldots \ldots$

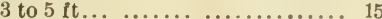

Syringa-leaved, 8 to $10 \mathrm{ft}$.

Teas' Japan, 6 to to 12 8 to $10 \mathrm{ft}$.

\section{Cornel. (Dogwood)}

Red Flowering, 18 in ................ 50

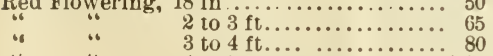

$\begin{array}{lll}\text { " } & \quad & 3 \text { to } 4 \mathrm{ft} \ldots \ldots \ldots \ldots \ldots \ldots \ldots \ldots\end{array}$

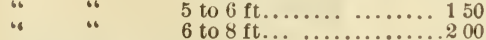

White Flowering, 2 to $3 \mathrm{ft} . . . \ldots \ldots \ldots . . .25$

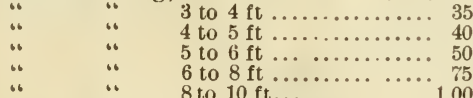

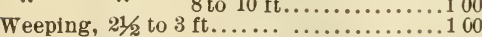

\section{Cypress.}

Chinese Weeping, 2 to $3 \mathrm{ft} . \ldots . \ldots \ldots \ldots . . . .35$ Deciduous 2 to $3 \mathrm{ft}$. . .

\section{Horse Chestnut.}

Common White Flowering, 3 to $4 \mathrm{ft}$....

" " 7 to 8 ft....... 100 Double, " " $6 \mathrm{ft} \ldots \ldots \ldots .100$ Red Flowering, 2 to $3 \mathrm{ft} \ldots \ldots \ldots \ldots \ldots \ldots . . . .50$ 3 to $4 \mathrm{ft}$.

\section{Sppong}

E

\section{Elm.}

Ea. 100 American,

“"

Honey Locust.

Thornless, 5 to $6 \mathrm{ft} . \ldots \ldots \ldots \ldots \ldots \ldots \ldots . \ldots 25 \quad 1500$ 6 to $8 \mathrm{ft} \ldots \ldots \ldots \ldots \ldots \ldots \ldots \ldots \ldots, 35 \quad 2000$ 8 to $10 \mathrm{ft} . . . . .40-2500$

Judas Tree.

American, 2 to $3 \mathrm{ft} . \ldots \ldots \ldots \ldots \ldots \ldots \ldots . \ldots 15 \quad 800$

Kolreuteria.

Paniculata, 4 to $5 \mathrm{ft} . \ldots \ldots \ldots \ldots \ldots \ldots . . \ldots . . .65$

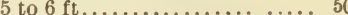

Laburnum.

Scotch or Common, 3 to $4 \mathrm{ft} \ldots \ldots \ldots \ldots . . .25 \quad 2500$ 4 to $5 \mathrm{ft} \ldots \ldots \ldots \ldots \ldots, 35 \quad 2000$

6 to $8 \mathrm{tt} . \ldots \ldots \ldots \ldots \ldots . . .50 \quad 3000$

Larch.

European or Scotch. 2 to $3 \mathrm{ft} . . . . . . . . .25 \quad 1500$

3 to 4 ft................ $35 \quad 2000$

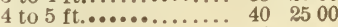

5 to $6 \mathrm{ft} . \ldots \ldots \ldots \ldots . .50$

Lilac.

Tree, $2 \mathrm{ft} \ldots . . . . .2$.

Linden.

American, 4 to $5 \mathrm{ft} . . . \ldots \ldots \ldots \ldots \ldots$......... 0

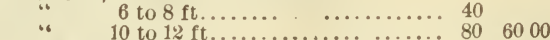

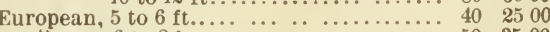

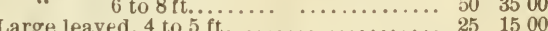

White or silver-leaved, 3 to $4 \mathrm{ft}$........... 40

4 to $5 \mathrm{ft} . \ldots \ldots .50$

6 to $8 \mathrm{ft} \ldots . . \ldots \ldots$..... 75

Liquidamber.

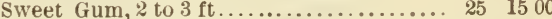

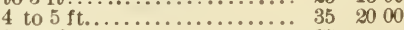

Magnolia.

Conspicua, 2 to $3 \mathrm{ft} . \ldots \ldots \ldots \ldots \ldots \ldots$........... $\tau$

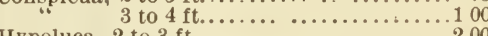

Hypoluca, 2 to $3 \mathrm{ft} . . . \ldots \ldots \ldots \ldots \ldots \ldots \ldots . \ldots 200$

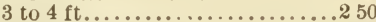

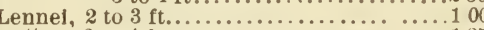
3 to $4 \mathrm{ft} \ldots \ldots \ldots \ldots \ldots \ldots \ldots \ldots \ldots \ldots \ldots \ldots \ldots$

Parviflora, 2 to $3 \mathrm{ft} . . . \ldots \ldots \ldots \ldots \ldots \ldots . . . . . . . .200$

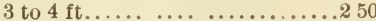

ulangeana, 2 to $3 \mathrm{ft} . \ldots \ldots \ldots \ldots \ldots \ldots \ldots, 75$

3 to $4 \mathrm{ft} \ldots \ldots \ldots \ldots \ldots \ldots \ldots . . . .100$

Mountain Ash.

European, 3 to $4 \mathrm{ft}$.................... 20 1000

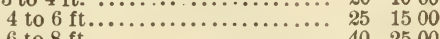

Oak-leaved, 6 to 8 it....................... 60 2500

\section{Mulberries.}

Japan, 5 to $6 \mathrm{ft} \ldots \ldots \ldots \ldots \ldots \ldots \ldots \ldots \ldots \ldots, 15 \quad 800$

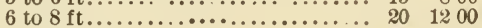

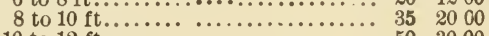

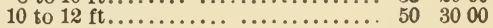




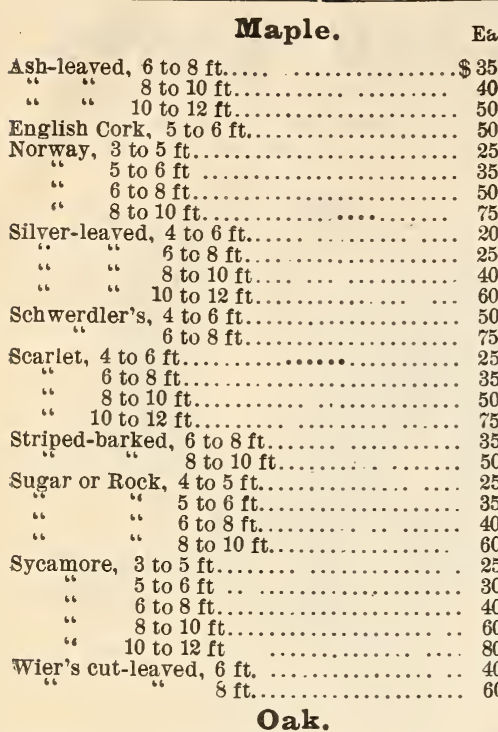

Mossy Cup or Burr, 2 to $3 \mathrm{ft}$.

Pin, 4 to $5 \mathrm{ft} . . . \ldots \ldots . . . . . .$.

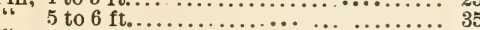

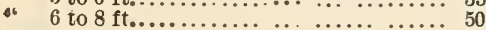

Scarlet, 4 to $5 \mathrm{ft} \ldots \ldots \ldots \ldots \ldots \ldots \ldots \ldots \ldots \ldots . . . \ldots \ldots$

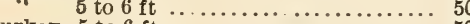

Turkey, 5 to $6 \mathrm{ft} . \ldots \ldots \ldots \ldots \ldots \ldots \ldots \ldots \ldots \ldots \ldots \ldots \ldots \ldots \ldots \ldots \ldots^{50}$

\section{Paulownia.}

Imperialis, 8 to $10 \mathrm{ft} . \ldots \ldots \ldots \ldots \ldots \ldots .50$

\section{Poplar.}

Bolleana, 4 to $5 \mathrm{ft}$................

$\begin{array}{ccc}" \text { " } & 6 \text { to } 8 \mathrm{ft} \ldots \ldots \ldots \\ " & \text { " } & \text { stocky, } 8 \text { to } 10 \mathrm{ft} \text {. }\end{array}$

Green-leaved, 5 to $6 \mathrm{ft}$. $10 \mathrm{to} 12 \mathrm{ft}$

Lombardy, 5 to $6 \mathrm{ft}$....

$$
\begin{array}{r}
6 \text { to } 8 \mathrm{ft} \text {. } \\
8 \text { to } 10 \mathrm{ft} \\
5 \text { to } 6 \mathrm{ft} . . . \\
8 \text { to } 10 \mathrm{ft} . .
\end{array}
$$$$
10 \text { to } 12 \mathrm{ft}
$$

Van Geerts Golden, 4 to $5 \mathrm{ft}$

5 to $6 \mathrm{ft}$

\section{Rhus.}

Osbecki, 10 to $12 \mathrm{ft} . \ldots . \ldots \ldots \ldots \ldots \ldots .75$

\section{Salisburia (Maiden Hair.)}

$\Delta$ diantifolia $11 / 2$ to $2 \mathrm{ft}$

$$
2 \text { to } 3 \mathrm{ft} \text {. }
$$$$
3 \text { to } 4 \mathrm{ft} \text {. } 5 \text { to } \mathrm{ft} \text {. }
$$

\section{Sycamore, (Buttonwood.)}

Oriental, (Plane) 4 to $5 \mathrm{ft} . . . . . . . . . .25 \quad 2500$ 5 to $6 \mathrm{ft} \ldots \ldots \ldots \ldots \cdots \cdots \cdots \cdots \cdots$

\section{Thorn.}

Double Scarlet, Rose and White, 4 tu $5 \mathrm{ft}$. . 50

\section{Tulip Tree.}

Liriodendron, 4 to $5 \mathrm{ft}$

$$
\begin{aligned}
& 5 \text { to } 6 \mathrm{ft} \text {. } \\
& 6 \text { to } 8 \mathrm{ft} \text {. } \\
& 8 \text { to } 10 \mathrm{ft} \\
& \text { Virgilea (Yellowwood) }
\end{aligned}
$$

Lutea, 2 to $3 \mathrm{ft} .$.

\section{Willow.}

Ea. 100

2000 Common Weeping, 6 to $8 \mathrm{ft} \ldots \ldots \ldots \ldots \ldots \ldots . \$ 25$

$\$ 25 \$ 1500$

Diamond, 6 to $8 \mathrm{ft}$ to $12 \mathrm{ft} \ldots \ldots \ldots \ldots \ldots \ldots, 50 . \cdots \cdots$

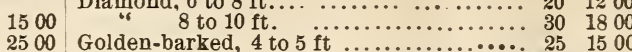

2500 Golden-barked, 4 to $5 \mathrm{ft} \ldots \ldots \ldots \ldots \ldots \ldots \ldots . . \ldots \ldots$

Laurel-leaved, 4 to $5 \mathrm{ft} . \ldots \ldots+20 \quad 1000$

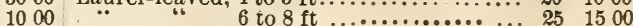

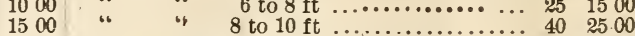

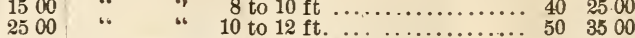

4000 Red-barked, (Britzensis) 4 to $5 \mathrm{ft} \ldots \ldots \ldots . . .251500$

Royal (Regalis) 4 to $5 \mathrm{ft} \ldots \ldots \ldots \ldots \ldots \ldots . . . . . . .35$

Royal (Regals) 5 to $6 \mathrm{ft} \ldots \ldots \ldots \ldots \ldots \ldots \ldots . . . \cdots$

Russellina, 4 to $6 \mathrm{ft} . \ldots \ldots \ldots \ldots \ldots \ldots \ldots \ldots \ldots$. $25 \quad 1500$

Salaman'sWeeping, 4 to $6 \mathrm{ft} \ldots \ldots \ldots \ldots \ldots \ldots$............... 1200

3500

1200

2000

2500

4000

1200

merican, 12 to 18 in

18 to 24 in...

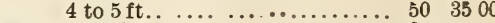

Chinese Golden, $1 \mathrm{ft}$.

$21 / 6$ to 3 ft $\ldots \cdots \cdots \cdots \cdots \cdots \cdots \cdots$

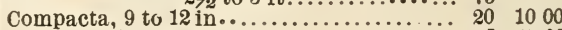

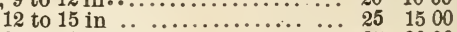

1800

2500

Conica densa, 12 to 18 in.

2 2 to $21 \% \mathrm{ft}$

$21 / 2$ to $3 \mathrm{ft}$

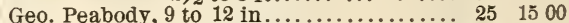

12 to 18 in.................................... 3500

18 to 24 in ................... 40 25 00

2 to $21 / 2 \mathrm{ft} \ldots \ldots \ldots \ldots \ldots, 60 \quad 4000$

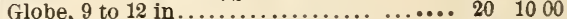

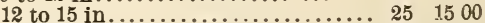

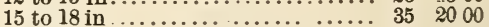

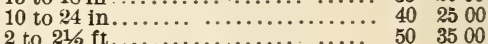

Hovey's Golden, 12 to 18 in............. $35 \quad 2000$

18 to 24 in ............. $40 \quad 2500$

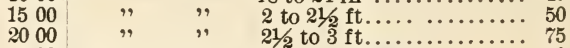

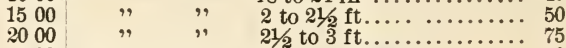

Little Gem, 12 to 18 in. across....... 50 ... 251500

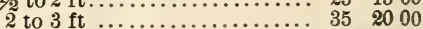

3 to $4 \mathrm{ft} \ldots \ldots \ldots \ldots \ldots \ldots \ldots \ldots \ldots$. $50 \quad 3000$

4 to $5 \mathrm{ft} \ldots \ldots .600 .60$

5 to $6 \mathrm{ft} \ldots \ldots . \cdots \cdots$

1800

2500

1000

1500

2000

2500

3000

3500

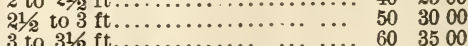

1000

1500

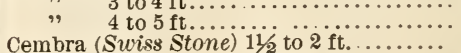

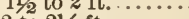

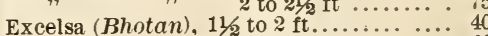
$11 / 2$ to 1 ................. 40 Dwarf Mugho, 2 to $21 / 3 \mathrm{ft}$. across............. 35 $21 / 2$ to $3 \mathrm{ft}$.

Pondorosa, 12 to 18 in............... 35

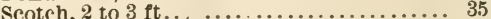

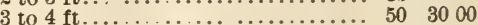

4 to $5 \mathrm{ft} \ldots \ldots \ldots \ldots \ldots \ldots \ldots \ldots \ldots \ldots, 60$

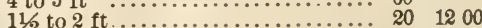

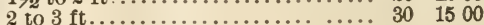

3 to $4 \mathrm{ft} \ldots \ldots \ldots \ldots \ldots \ldots \ldots \ldots \ldots . . \ldots \ldots$

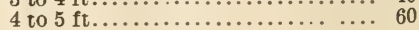

1200

1800

2500

3500 


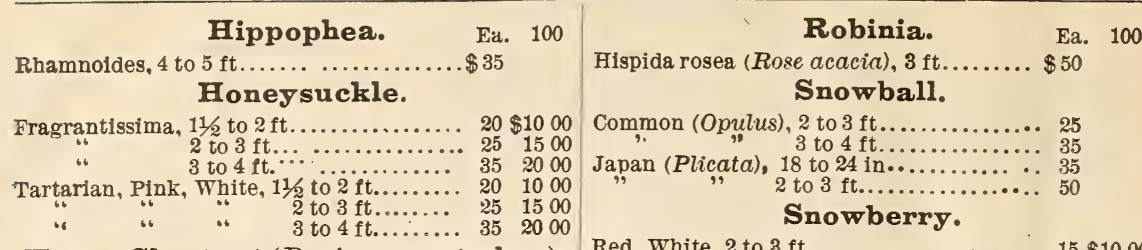

Horse Chestnut (Pavia macrostachya.)

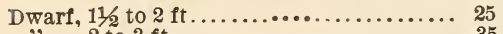
2 to $3 \mathrm{ft} . \ldots \ldots \ldots \ldots \ldots \ldots \ldots, 35$

\section{Hydrangea.}

Panleulata grandiflora, 12 to 18 in....... 15 $11 / 2$ to $2 \mathrm{ft} . \ldots$.
2 to $21 / 2 \mathrm{ft} . \ldots \ldots$
$21 / 2$ to $31 / 2 \mathrm{ft} . \ldots . \cdots$

Ramulus Coccinea (Red- $\tilde{B} r^{\prime} d$ ) 3 in. pots

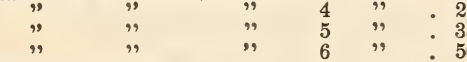

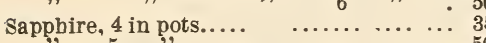

, 5 , ................. 50

Thomas Hogg, Otaksa. 4 in. pots............. 25

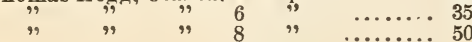

Judas.

Japan, 12 to $18 \mathrm{in} . \ldots \ldots \ldots \ldots \ldots \ldots \ldots \ldots \ldots$. 25 1500

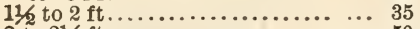

2 to $21 / 6 \mathrm{ft} . . . \ldots \ldots \ldots \ldots \ldots \ldots . \ldots . \ldots$

Japan Quince.

Scarlet, $1 \frac{1}{2}$ to $2 \mathrm{ft} . . . \ldots \ldots \ldots \ldots \ldots \ldots . . . . .15$

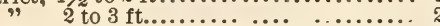

3 to $4 \mathrm{ft} . . \ldots \ldots \ldots \ldots \ldots \ldots . . . . .25$

White, $11 / 6$ to $2 \mathrm{ft} \ldots \ldots \ldots \ldots \ldots \ldots \ldots \ldots 20$

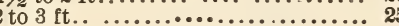

\section{Lilac.}

Charles X, 3 to $4 \mathrm{ft} . \ldots \ldots \ldots \ldots \ldots \ldots \ldots \ldots . . \ldots 25$ " 4 to $5 \mathrm{ft} . \ldots \ldots \ldots \ldots \ldots \ldots \ldots \ldots \ldots . \ldots 35$ Common Purple, 2 to $3 \mathrm{ft} . . . \ldots \ldots \ldots \ldots \ldots . . . . .15$ $"$ " 3 to $4 \mathrm{ft} \ldots \ldots \ldots \ldots \ldots \ldots \ldots$... 20 ,$\quad$ White 2 to $3 \mathrm{ft} \ldots \ldots \ldots \ldots \ldots \ldots \ldots .25$

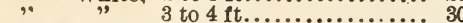

Josikea, 2 to $3 \mathrm{ft} . \ldots \ldots \ldots \ldots \ldots \ldots \ldots \ldots \ldots . \ldots . \ldots 25$

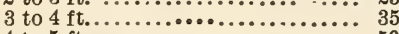

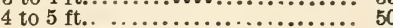

Persian, Purple. White, 2 to $3 \mathrm{ft} . . . \ldots \ldots$. 20 Rubra de Marley 2 to $3 \mathrm{ft} . \ldots \ldots \ldots \ldots \ldots \ldots . . . . .20$

Souvenir de L'Spath, 2 to $3 \mathrm{ft} . . \ldots \ldots \ldots \ldots \ldots \ldots . .75$

\section{Maples.}

Japanese ( $A$. polymorphum) 2 to $213 \mathrm{ft}$... $50 \quad 3500$ Blood-leaved, 2 to $3 \mathrm{ft} . . . . . . . .150$ 3 to $4 \mathrm{ft}$

\section{Pronia.}

Tree, 6 to 12 in.......................100

\section{Privet.}

California, 12 to 18 in................. 10

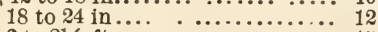
2 to $2 \frac{1}{2}$ ft.................... 15

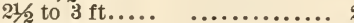
4 to $5 \mathrm{ft}$.

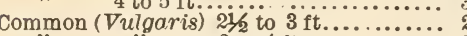
3 to $4 \mathrm{ft} \ldots \ldots \ldots \ldots \ldots$

Laurel-leaved, 2 to $3 \mathrm{ft} . \ldots \ldots \ldots \ldots \ldots \ldots . . . .$.

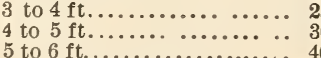

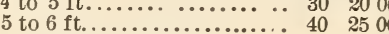

\section{Prunus.}

Pissardil, 2 to 3 ft................... 20

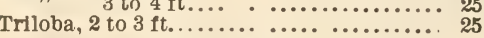

\section{Rhodotypus.}

Kerrioides, 2 to $3 \mathrm{ft} . . . \ldots \ldots \ldots \ldots \ldots \ldots 20$

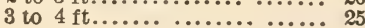
1000 1500 2000 3500 1200
700 Catesbei, $11 / 2$ to $2 \mathrm{ft}$.

Spirea.

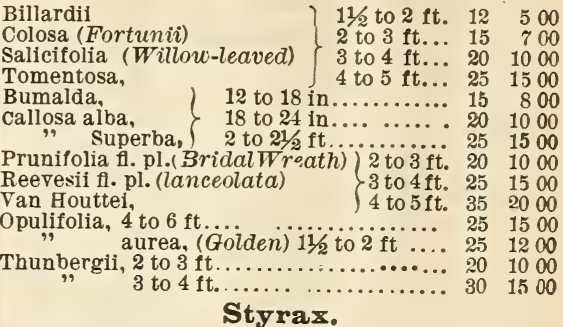

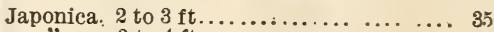

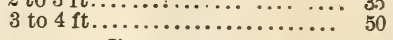

Syringa.

Golden-leaved, 6 to 9 in...... ....... $15 \quad 800$ 9 to 12 in.................... $20 \quad 1200$ 12 to 18 in...............25 1500

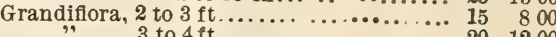

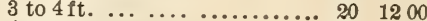

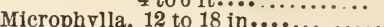
Mock Orange (Coronarins) $11 / 2$ to 2 it......... 15800 $\begin{array}{lllll}", & 2 \text { to } 3 \mathrm{ft} \ldots \ldots \ldots & 20 & 1000 \\ & 3 \text { to } 4 \mathrm{ft} \ldots \ldots \ldots & 25 & 1500\end{array}$ "Double flowering, $11 / 4$ to $2 \mathrm{ft} \ldots . .2$. 251500 Tamarix.

Indian, African, 2 to $3 \mathrm{ft} . \ldots \ldots \ldots \ldots \ldots . \ldots 15 \quad 800$ 3 to $4 \mathrm{ft} . \ldots \ldots \ldots \ldots \ldots \ldots 20 \quad 1000$ 4 to 6 it................ $25 \quad 1500$ Weigela.

Amabils, ] 2 to $3 \mathrm{ft} . . . \ldots \ldots \ldots \ldots \ldots . \ldots 15 \quad 800$

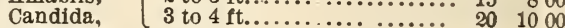
Desboiseli, $\} 4$ to $5 \mathrm{ft} . \ldots \ldots \ldots \ldots \ldots \ldots \ldots \ldots . . \ldots 301500$ Rosea, $\int 5$ to $6 \mathrm{ft} . \ldots \ldots \ldots \ldots \ldots \ldots \ldots$ Floribunda, $11 / 2$ to $2 \mathrm{ft}$..... 15800 Dwarf Varigated-leaved, 2 to $3 \mathrm{ft} . . . \ldots .20 \quad 2000$ La Vallee,
Multiflora, $\quad\left\{\begin{array}{l}3 \text { to } 4 \mathrm{ft} . \ldots \ldots .25 \\ 4 \text { to } 5 \mathrm{ft} . \ldots . .25\end{array}\right.$

EVERGREEN SHRUBS. Andromeda.

\section{Azalea.}

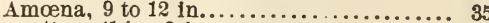

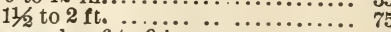
superba, 6 to 9 in................. 50 lili-flora alba, 6 to $9 \mathrm{in} . . . \ldots . .50$

\section{Box.}

Common Tree, 12 in................ 35 18 in $\ldots \ldots \ldots \ldots \ldots \ldots \ldots . \ldots \ldots$ " * $2 \mathrm{ft}$. shorn. ............ 75 Long-leaved, 2 to $21 / 2 \mathrm{ft}$. shorn............... 90 Euonymns.

Radicans varigata, 6 to 9 in

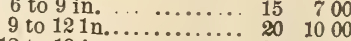

12 to 18 in............... $25 \quad 1500$

Holly.

1000 European, 9 to 12 in.................. 35

\section{Laurel.}

Mountain Broad-leaf (latifolia) 6 to 9 in... 25 9 to 12 in.. 35 $1500 \quad$ “ Narrow-leaf (Aug'folia) 9 to 12 in.. 25 


\begin{tabular}{|c|c|}
\hline & Mahonia. \\
\hline $\begin{array}{l}\text { Aquifolia, } \\
: .\end{array}$ & 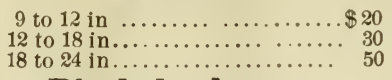 \\
\hline & Rhododendrons. \\
\hline Finest ${ }_{.6}$ Har & $\begin{array}{l}\text { rdy sorts, named } 15 \text { to } 20 \ln . \ldots \ldots 100 \\
18 \text { to } 24 \text { in. with buds..1 } 25\end{array}$ \\
\hline “ & $\begin{array}{l}24 \text { to } 30 \text { in. } \\
\text { Yucca. }\end{array}$ \\
\hline
\end{tabular}

Filamentosa, (Adams Needle) 2 yrs..

\section{VINES AND CREEPERS. Actinidia.}

Polygama,

\section{Akebia.}

Quinata, strong...................
Ampelopsis.

Quinquefolia, (Am. Ivy) 3 to $5 \mathrm{ft}$..

Veitchli, (Japan Ivy) 3 to 5 ftrong...

extra strong

\section{Aristolochia.}

Sypho, (Dutchmans pipe) .........

\section{Clematis.}

Flakula, (Virgin's Bower)

Henryil, 2 yrs...........

Jackmanii, 2 yrs

alba, 2 yrs

\section{Honeysuckle.}

Halls Japan,

Japan golden veined ) $\begin{array}{lllr}1 & \mathrm{yr} . \ldots . & 15 & 700\end{array}$

Red Coral $\} \begin{array}{llll}2 \text { yrs......... } 20 & 1000\end{array}$ I $\mathbf{v y}$.

Irish, 2 to $3 \mathrm{ft}$

Myrtle. (Periwinkle)

Minor, Blue, White................................

\section{Trumpet Creeper.}

Tecoma radicans, strong.

\section{Wistaria.}

Chiruese Blue, ...................... 15800

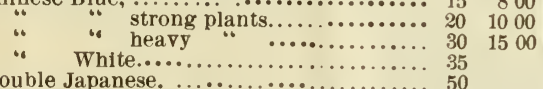
HARDY HERBACEOUS PLANTS. Achilla, double White.............. $15 \quad 800$ The Pearl........................... $15 \quad 1000$ Anemone Japonica (White, red).............. 20 1200

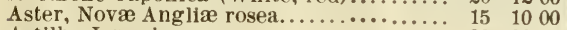
Astilbe Japonica.................... 20 1200 Boltonia latisquamæ................ $20 \quad 1200$

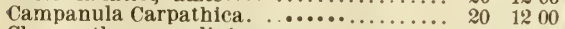
Chrysanthemum uliginosum................ $20 \quad 1200$
100 Cor

Convallaria majalis.

Coreopsis lanceolata.

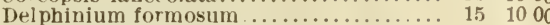

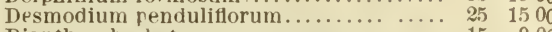

Dianthus barbatus.................... 15900 plumarius roseus plenus.

Dicentra spectabilis. .......... $20 \quad 1200$

Digitalis purpurea................. 151000

Erainthus Ravennæ. .............. . 151000

Eulalia gracillima univittata.......... 151000 Japonica variegata.............. 151000

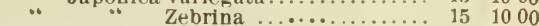

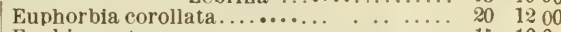

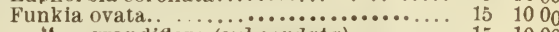

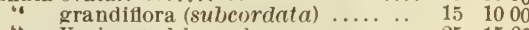

Variegated-leaved.................

Gillardia grandiflora................................. 1200

Geraneum sanguineum................... 151000

Glaucium lutea (Horned Poppy)................. 800

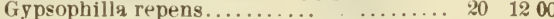

Helleborus nigrus, (Christmas Rose) ... 20

Hemerocallis flava,................... $15 \quad 800$ fulva fl. pl... $\ldots \ldots \ldots \ldots \ldots \ldots . \ldots \ldots$ Thunbergii............................ 25,1500

201000 Helianthus multiflorus plenus,..............

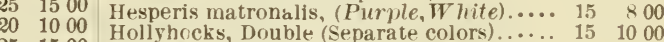

$\begin{array}{llll}\text { Hollyhocks, Double (Separate colors)....... } & 15 & 1000 \\ \text { Iberis sempervirens, (Hardy Candytuft).. } & 20 & 1200\end{array}$

Iris cristata,

German, (Finest named)

“ Krempferli, (Jripan) ............. 151000

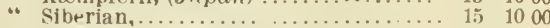

Lathyrus latifolius, Scarlet.................. 25

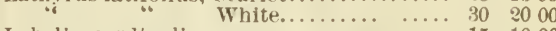

Lobelia cardinalis.

Lychnis Haageana, (Burning Star)........ 151000 Visearia tl.pl. (Rayged Robini)... 151000

Myosotis, Blue perfection ............. $35 \quad 2000$

Mountain Fleece,........................ 1500

Oenothera speciosa (Evening Primrose).

.. Ice King, ............. 251500

Papaver Orientale......................... 151000

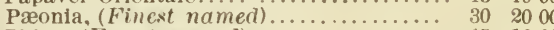

Phlox, (Enmest named)

"A Amæna (Duarf)................ 25

* subulata....................... 151000

Platycodon grandiflora........................ $15 \quad 800$

Plumbago larpentre.

Primula ancaulis rubra (English). ....... $20 \quad 1200$

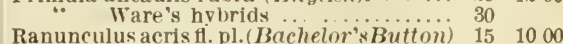

Rhexia Virginica.

Sedum spectabilis. ................ 151000

Solidago odora (Golden Rod)............. 20

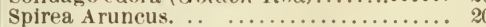

" flipendula fl. $\mathrm{pl} \ldots \ldots \ldots \ldots \ldots \ldots \ldots \ldots 2_{25} 1500$

“ lonata......................20 1200

“ palmata elegans.............. 25

“ ulmaria fi. pl ................ $25 \quad 150$.

. venusta variegata............ $25 \quad 1500$

Tradescantia Virginica................... $25 \quad 1500$

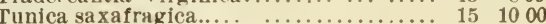

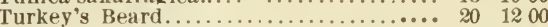

Veronica amethystina................... 151000

.. incana ....................... 151000

Viola cornuta (Blue. White)

odorata Marie Louise)................ 25

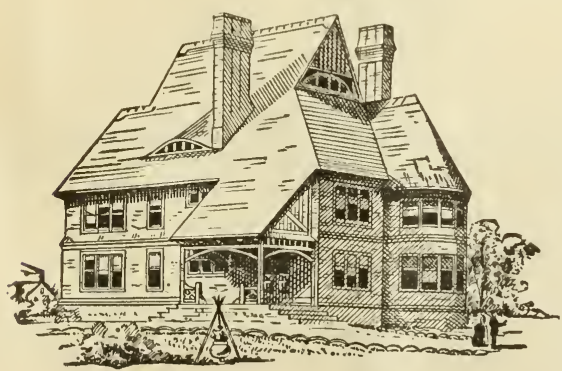

A neat Atlas entitled-SENSIBL $\mathbf{L} \mathbf{L}$ Cos' HOUSES-How to Build Them now ready. This contains plans. illustrations and complete description of 56 New, Beautiful aud Cheap Country Houses, costing from $\$ 800$ to $\$ 7,500$. Shows how you can build a $\$ 2,000$ house for $\$ 1,700$, and how to make them handsome, convenient, healthy, light, cool and airy in summer, warm and cheaply heated in winter. Tells intended builders of homes what to do and warns them what not to do. Describes houses adapted to all climates. If you intend to build now or twenty years from now, you want this book. Price $\$ 1.00$ by mail postpaid. Address, 


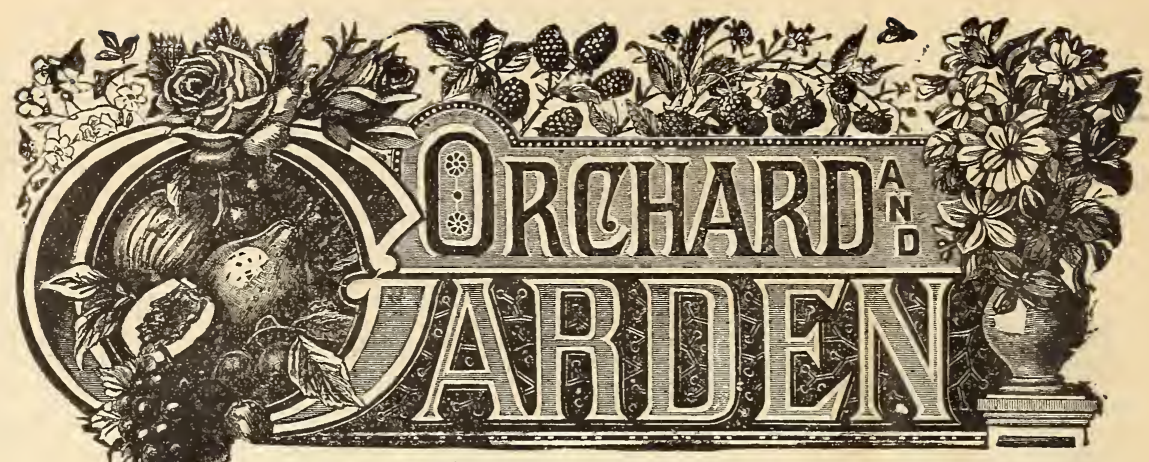

A NATIONAL JOURNAL OF HORTICLLTURE.

Illustrated and Published Monthly.

Devoted to the interests of American Fruit-growing and Gardening. The brightest and most practical horticultural Journal published. Ahead of all other papers of the kind in originality, reliability, and practical solid sense. Everybody should read it. It tells how to make the garden proftable. Its writers are among the foremost horticulturists and scientists on this Continent, and every article is contributed by a specialist on the subject of which it treats. Its departments are;:

THE ORCHARD.- Our staple fruits are dealt with under this heading. The planting of orchards: culcure and pruning of the trees; marketing and storing of the fruit, etc., etc.

THE VINEY ARD.-The merits of new varieties are faithfuily reported; new methods of culture discussed and the experience of practical growers interchanged.

THE VEGETABLE GARDEN.-Devoted not only to the home garden hut also to the interests of market gardeners, North and South. Best varieties and best methods of culture are fully discussed.

THE BERRY PATCH.-The small fruits are here treated exhaustively-new varieties, planting, culture, marketing, etc., are given special attention.

NUTS AND NUT TREES.- We give special prominence to this industry, believing it to be one of the most profitable and with a big future.
BIOGRAPHY.-A portrait and brief blographical sketch of leading horticulturists is given monthly.

INSECTS.-The special pests of the horticulturist are flgurcd and described, and remedies suggested.

THE FLOWER GARDEN.-Full particulars regarding the management of flowers are given; new and valuable sorts illustrated and described, etc.

THE LAWN AND PARK.-The ornamentation of home grounds, treatment of ornam+ntal trees and shrubs is here given.

THE HOUSEHOLD.--Every housewife may find something useful in this department; domestic economy, hints and suggestions, etc., etc.

Reports of Horticultural Societies, Editorial Comments, etc., etc.. all combine to make it the most helpful and practical Journal of the kind published. It is pre-eminently

\section{THE IDEAL JOURNAL FOR THE COUNTRY HOME. \\ Written, Edited and Published by Practical Horticulturists.}

In the future, as in the past, the determined and prepared to keep this publications in America. No efforts and pages with thoroughly practical and the foremost horticultural scientists and effect; but we do aim to give our readers interest to horticulturists and to make value to all subscribers. Its original, tained and it will continus o be entirely sive. The illustrations will be more artists and engravers, will be employed

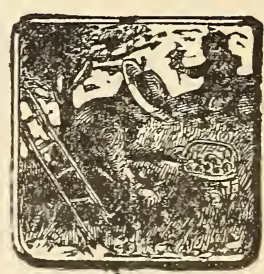

publishers of ORCHARD \& GARDEN are Journal at the head of all horticultural no expense will be spared to fll its instructive articles from the pens of writers. We do not aim at literary trustworthy information on all topics of the paper entertaining and of fullest practical character will be strictly mainindependent, seasonable and progresnumerous than heretofore and the best upon it, keeping it fully abreast of the times. Among our contributors are such eminent scientists and horticulturists as the following:
T. H. HOSIKINS, VERMONT.
J. L. BU DD, IOWA.
J. STA Y I A N, KANSAS.
F. LA ISO N-SCRIBN ER, TENN.
F. J. NISW A N DER, MICHIGAN.
A. S. FULLEl., NEW JERSEY.
W. J. GR EEN, OHIо.
ISA AC HICKS, NEW YORK.
J. TROOP, INDIANA.

E. WILLIAMS, NEW JERSEY.

S. MILLER, MISSOURI.

D. B. WIER, CALIFORNIA.

PETER IB. IIEAD, Massachosetts.

W. F. MISSEY, NORTH CAROLINA.

T. D. BAIL D, KENTTCKY.

J. W. II A N I N G, MASSACHUSETTS.

W. FALCONER, NEW YORK.

A. F. COR DLEY, VERJont.

\section{ONLY FIFTY CENTS A YEAR.}

or Three Months Trial Trip for Ten Cents. Sample Copies free.

We will mail the Journal a whole year free to any one sending us a Club of four. subscribers and two dollars, or to any one sending us a club order for trees and piants at each and dozen rates of the Guide to the amount of \$3.50. 


\title{
FUNGUS DISEASES
}

OF THE

\section{GRAPE \& OTHER PLANTS,}

\author{
AND THEIR
}

TREATMENT,

B Y

F. LAMSON-SCRIBNER,

Professor of Botany in the University of Tennessee; Director and Botanist to the Agricultural Experiment

Station of Tennessee; Fellow of the American As-

sociation for the Advancement of Science; Mem-

ber of the Academy of Natural Sciences of Phil-

adelphia, Blological Society of Washington,

Society for the Promotion of Agricultural

Science; Corresponding Member of the

Buffalo Academy of Naturalscience and

the Correy Botanical Club; Chevelier

du Merite Agricole (of France); etc.

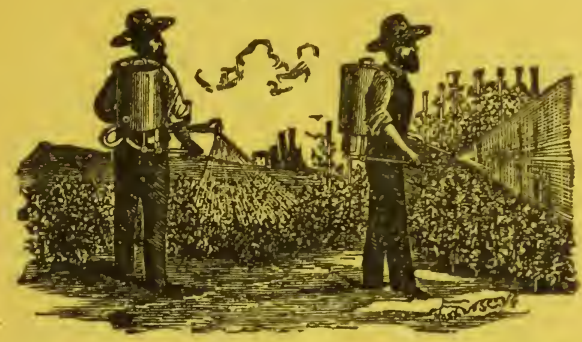

Prepared especially for the Vineyardist, Fruit Grower and Gardener of to-day and treats the subjects presented in the freshest and most practical manner.

Octavo-134 Pages, $5_{2}^{1} \times 8$ in., Fully lllust'd. Price in Cloth, 75c; Paper, 50c. By Mail Postpaid.

PUBLISHED BY

J, T. LOVETT COMPANY, LITTLE SILVER, N. J. 
2

\section{TABLE OF CONTENTS.}

CHAPTER.

I. The Essentials for Study. What are Fungi?

III. Bxperiments in the Treatment of Black-Pot of Grapes........................

IV. Bitter-Rot. White-Rot.

V. Brown-Rot. .......................... 45

YI. The Powdery Mildew of the vine.......... 55

VII. Grape Leaf Blight..... . . .............. 60

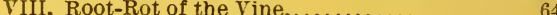

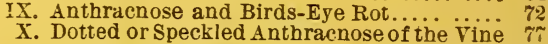

XI. Black-Rot of the Apple ............... 81

XII, Apple Rust and Cedar Apples.......... 84

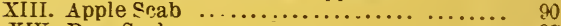

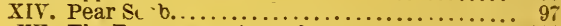

XV. The Entomosporium of the Pear and Quince 101

XVI. Plum Rot or the Monilia of Fruit.......... 10

XVII Black-Knot of the Plum and Cherry...... 111

$X$ VIII. Leaf-Spot Disease of the Plum and Cherry 119

XIX. Powdery Mildew of the Cherry.... ....... 122

XX. Peach Leaf Curl ........................ 126

XXI. Fungus of the Raspberry Anthracnose..... 131

\section{ILLUSTRATIONS.}

Effect of black-rot fungus on the grape leaf-Grape berries destroyed by Black-rot-The mycelium of the Black-rot fungus-Vertical section of a pustule, greatly magnifled-Magnifled view of Black-rotfungus as seen in grape leaf-Stylospores germinating-spermatiaMode of spraying vines-Portion of vine attacked by Black-rot and not treated-Portion of vine treated with the Bordeaux mixture-Fungus of Bitter-rot-Spores of Bitter-rot attached to their pedicels-Fungus of Whiterot-Spores of White-rot germinating-Spores of White rot attached to their pedicels-Mycelial threads of the Downy Mildew, seen in the tissue of the berry-Grape berries attacker byBrown-rot-Powder bellows-Agaricus melleus-Vine root affected with Pourridie-Sporebearing fruiting stalks of Dematophora necatrix-Colorless mycelial flaments of Dematophora necatrixPiece of root killed by the Dematophora-Birds-eye-rot of grapes-Vertical section of pustule in apple Blackrot-Spores of Apple Rust and cedar apples-Fragment of diseased apple leaf-Cedar apple-Apple-scab-Fungus of Apple-scab-A young pear affected by Pear-scab - Section of portion of pear-leaf showing fungus growth - Leaves of quince and pear attacked by Blight-CrackIng of the pear caused by Entomosporium-Fungus of Pear-leaf Blight and Quince-leaf Blight-Black-knot of plum and cherry-Leal-spot disease of the cherryMagnifled section of cherry leaf showing fungus-Powdery Mildew of the cherry-Mycelium of the Peach-leaf Curl fungus-Peach-leaf Curl. Diseased shoot and leaf -Raspherry Anthracnose. Diseased raspberry cane. 


\section{ITS SCOPE AND CHARACTER.}

The subject of grape diseases is one that demands ecnsiderable attention from vineyardists and others by reason of the terrible ravages committed by them. To successfully combat and overcome the various fungus diseases promptly as they appear requires a knowledge and familiarity that can be only gained by the study of such a work as this.

The author is the foremost authority in the country upon this subject, and fungi have been special subjects of study with him for almost a lifetime. The various fungus diseases are treated in a concise and practical manner impressing upon the reader the general characteristics of the disease and ready means for its identiflcation. The details are quite fully given in each case and remedies suggested wlth mode of application. It will be found to supply all that is necessary to be known to the intelligent fruit grower and vineyardist to enable him to prevent fungus diseases or to fight them when they do appear. To ald in their identiflcation a large number of illustrations are given (upwards of sixty) all of which are original and drawn expressly for this work by Prof. Scribner himself. A carefully prepared and convenient index add completeness to the book.

At this time when the hopes of all horticulturists are directed to spraying as a means of checking the advancing and spreading disease, this book, written by such an authority on Fungus Diseases as Prof. Scribner, is especially valuable and timely, and it is the only work of its kind that has yet been published. It may therefore very justly be considered a necessary adjunct to the equipment of every gardener and fruitgrower of to-day.

This book has been accorded a hearty welcome by the horticultural press and by horticulturists generally. It is a work that is especially needed at this time, and that it is well appreciated is fully shown by the annexed testimonials and expressions of opinion from both press and people, of which many more might be printed did space permit. 


\section{OPINIONS OF THE AUTHORITIES,}

No ONE BetTer FitTed To WRITE IT.-I am glad that you induced Prof. Scribner to write the work on Fungus Diseases of Grapes and Other Plants. Noperson coukd be found better fitted for such a task, and I am sure the manner in which he has accomplished his task will commend itself to all who are familiar with the rust, mildews and moulds which affict borticulturists. It is pleasant to me to see so much developed in this direction, when over a quarter of a century ago, some few of us, as practical horticulturists, insisted that small fungi would attack healthy vegetation, and cause disease, were laughed at, and even so good a friend and intelligent botanist as Prof. Thurber, invented the term of fungo-probists for those of us who contended this fact. There was scarcely an under-glass grape grower but had seen fungus from rotton wood, spreading from rotten wood to the stems of grape vines in the vineries, eating its way all around the stems. We had seen fungus on Rhododendrons generated in rotten leaves and eating around and girdling the stems; we had seen the fungus from rotten wood in the earth from the Mycelium or spawn of the mushroom known as the Agaricus melleus, spreading from the rotton wood in the soil to the roots of pines, firs and other trees, rendering the plants as yellow as a Peach tree with the "yellows." We had seen and known all this, before the man with a microscope came along to tell us the exact names of the fungus plants, acting in this way. Now they have gone ahead of us, and what with Baccilli, Microbes, and many other of the low forms of vegetation, contend for plant diseases by their agency much more fervently than the old horticulturist with all his advance of knowledge, had ever dreamed of. One of the merits of Prof. Scribner's book is, that when he doesn't know he honestly says so. He doesn't know how the Peach-leaf Curl is propagated. It is known that it is a fungus, but just how it gets in a plant and starts its spores is not known. Considering how so many would know everything, it is not the least commendable part of Prof. Scribner's work that when he doesn't know, he says so. I am quite sure there is no one interested in fruit growing, or in diseases of plants generally, but will be very thankful that this excellent work of Prof. Scribner's has been published.THomas MrEHaN, Botanist of the Pennsylvania Board of Agriculture.

OF MCCH PRACTICAL VALde.-I hate read Prof. Scribner's work upon "Fungus Diseases of the Grape and Other Plants" with much pleasure. This manual of the subjects treated cannot but convey much valuable information to those who have suffered from the maladies of cultivated plants. Rarely one finds so much that is of practical value brought together in so attractive and convenient a form for the crop grower. -BYRON D. HALSTEAD, Botanist and Horticultur 
VERY MUCH NEEDFD.-One of the most useful little books that has recently been offered to the farmer and fruit grower is F. Lamson-Scribner's Fungus Diseases of the Grape and Other Plants. It is a book that was very much needed and no one in the country is better able to give the best and latest information on the habits and means of destroying the many fungus pests attacking our fruits than Mr. Scribner, who was so favorably known as the Mycologist of the Department of Agriculture for many years. Mr. Scribner was one of the first to investigate the methods and the remedies used by European vineyaldists who had for many years been afficted with these pests, and were obliged to depend upon fungicides to prevent the black-rot and mildew from totally destroying their industry. The author treats in a very practical and comprehensive manner the various methods of overcoming, not only the diseases of the vine but also those attacking the apple, pear, peach, plum and cherry, and we have only to regret, that, with his large experience and knowledge of the subject, he did not also treat of the rusts, smuts, blights, etc., attucking our farm and garden crops, and have made the book a more comprehensive one. $-\mathrm{S}$. $\mathrm{T}$. MAYNARD, Botanist and Horticulturist, Mass. Agricultural College.

Thoroughly Practical and Easily Understood. -You have recently afforded me much pleasure by enabling me to look through the book on fungus diseases of fruits, published by you, and written by my friend. F. Lamson-Scribier. It is thoroughly practical, and its directions can be easily understood and followed by any intelligent farmer or fruit grower. It covers the leading diseases which prey upon the fruits of this country, and any one who wishes to keep up with the times, and expects to get the full benefits of science as applled to this subject, should not delay procuring a copy.-H. E. VAN DEMAN, U. S. Pomologist, Washington, D. C.

IT MARKS A NEW ERA. - Thanks for the copy of Prof. Scribner's very valuable work on Fungus diseases of our economic plants. It maiks a new era in our horticultural literature. In this country it is the first clear, concise and realiy practical work on this vitally important subject for the use of the worker in garden and orchard. I can think of no improvement unless it be adding a chapter on the fact that masa lands in California, and elevated moraines and ridges in the prairie states are less subject to fungus diseases of the cereals and fruits, than valley lands or great level expanses. This joined with the reasons would make a valuable addition.-J. L. BUDD, Professor of Horticulture, Iowa Agricultural College.

EASY TO UNDERSTAND.-Thanks for the "Fungus Diseases of the Grape and Other Plants" by Prof. Scribner. I think it very valuable. It is a popular manual about as easy to understand as any book of the kind can be. -W. J. BkA L, Professor of Botan\%, Michigan Agri. cultural College. 
EXCELLENT AND VALUABLE. - An excellent and valuable work, especially for the advanced vineyardist and horticulturist. The amateur may also find much in its pages which should interest him, for the author shows the why and wherefore of many minute but none the less very destructive maladies of trees and rines. $-\mathrm{A}$. S. FULLER, A uthor of The Grape Culturist, The Small Fruit Culturist, Etc., Etc.

THE BEST WORK OF THE KIND.-I wish to thank you for the book "Fungus Diseases of the Grape and Other Plants and their Treatment," by Prof. Lamson-Scribner. I have examined the contents with much care and interest, for it is a very interesting suhject to me, and have no hesitation whatever in pronouncing it the best work of the kind that I have seen or know of. We were in sore need of just such a book, something to tell us about the fungus diseases-blights, moulds and the like-that prey upon and destroy our fruit trees, bushes and vines, and how to prevent, check or destroy such serious evils, and here, replete with this information by the highest authority in the land, comes Prof. Lamson-Scribner's book, - a friend in need, a friend indeed. And be it to the learned author's praise, noit only has he rendered the text technically correct, but his language and teachings throughout are so plain and pointed that every tyro among us can understand them readily and iully. And we thank the author for the painstaking and thorough manner in which he handles his subject and illustrates it for our guidance. - WILLIA II FALCONER.

FULLY UP W」TH THE TIMES.-It seems to me to embody about all that is at present known of these destructive affections of our vineyards and orchards, and to express that knowledge in as plain and simple language as possible. Prof. Scribner shows great care and thoroughness in his work, and withal a regard for plain practicality, free from confusing technicalities, which is yet too rare with writers upon similar subjects. But I seem to notice th it in this case, as in others, we get clearness about in pro. portion to the exactness of the knowledge possessed by the writer. It is the man who clearly sees that can clearly describe; and it is the half iearned, cr the pretender, who usually plays the cutt) e-flsh in his writings.

As to that portion of the work which deals with prevention and cure, it seems to me to be quite up with the times. I congratulate you upon the issue of this new Handbook, and prophesy for it a rapid and extensive sale.-T. H. HOSKINS, M. D.

PRACTICAL, TIMELY, USEFCL.-Prof. Scribner's treatise is exceedingly opportune. At the present time fungus diseases seem to be the greatest obstacles to successful fruit culture, and every fruit grower will welcome information which will enable him to overcome come information which will enable him to overcome meet with general approval. The author and the publisher are to be congratulated upon the issue of such a practical,useful and timely publication.-T. C. BARRY. 
Written from Practical Experience.-Perhaps no book is so urgently needed by fruit growers at the present time as one giving clear and concise directions for controling the numerous fungus diseases that prey upon our fruit trees and plants. In Prof. Scribner's little work, we have a most admirable treatise for the diseases which it takes up. The book is well printed. upon good paper, and the ilustrations are especially fine. The life histories of the different fungi treated are given in clear and concise terms, followed by directions for preventing or controling their ravages. One element which gives this book a peculiar value is the fact that its author writes from abundant practical experience in the treatment of the diseases which he discusses. No other person in this country bas done so much in the fleld of grape diseases as Prof. Scribner, and hence no other person is so well qualifled to write such a book. One feels a satisfaction in reading it from the knowledge that the statements it contains are not compilations but are based upon careful experiments, very many of which were conducted under the author's immediate supervision. The book makes no pritense of being a complete treatise upun injurious fungi. It is conflued to those that attack fruits and of these some, as the flreblight of the pear and the rust of the strawberry, are not considered. But it is safe to say that no book heretofore published in this country gives so much useful information upon fungus diseases. It is to be commended to ali fruit growers as a most valuable handbook.-E. S. GOFF, Professor of Horticulture. University of tisconsin.

FULL OF THE SOUNDEST INFORMATION.-Scribner's "Fungus Diseases of the Grape and Uther Plants" is a most valuable addition to every day horticultural literature. It is a work full of the soundest information presented in such a simple and concise manner as to be easily understood. The illustrations are very good and the descriptions of them are to the point. Prof. Scribner has reduced his micromillimeters and his other meters to parts of inches, which is right, as there are but few tbat can carry f,reign measurements in their heads, and others do not know them. I hope this is the beginning of a series of books on the subject which shall apply to all branches of horticulture. The florists of America will hall with delight a book that shall give them as much information about fungus on roses, violets and carnations as does this volume on grapes, plums and cherries.-JOHN THORPE.

OF GREAT VALUE TO EVERY HORTICULTURIST.-COPy of "Diseases of the Grape andOther Plants" duly received. I desire especially to congratulate you on the publication of this very useful work in book form. It cannot fail to be of great value to every horticulturist by show. ing him how to combat the fungoid diseases of his vines and trees, and the mechanical work on the book compares favorably with the work of the best New York publishing houses.-C. C. GEORGkson, Professor of Agriculture, Kansas Agricul ural College. 
Clear. ACCCRate aND Practical. - I am exceec ingly well ple ssed with Prof. Scribner's "Fungus Diseases of the Grape and Other Plants." It appears to be just the work needed at this time. Like all of friend Scribner's work, it is rerr clear, accurate and practical. 'Now that it is fully demonstrated that to be successful fruitgromers we must destror, at the proper time and as thoroughly, the microscopie reeds ffungi) as well as the large ones subdued by the hoe and cultivator, this book comes at a most onportune time and tells in the shortest space how to do the work most thoroughly with the least trouble and expense. The illustrations are excellent and sufficient. This work should at once take its place as a standard and indispensable companion with Dorning, Thomas, Barr, Tharder, Fuller, and Husmann's popular works on fruit culture, and I fulls beliere it will.-T. T. Mrxsos.

THE PRICE Is Too LoT.-I hare examined Prof. Scribner's new book carefully and must sas that it is admirabls adapted to the purpose for which it is intended. It is not too technical for the understanding of the arerage reader, but at the same time scientific accuracy has not been lost sight of. Ererr fruit-gromer and rinerardist throughout the land should get a copy for hands reference. The book is beautifully printed and illustraced in Prof. Scribner's usual striking and accurate way. MY only objection is that the price is too low and rather an incenrenient one. Anr man who wants such a mork will give a dollar for it as readily as he will serenty-fre cents.-F. T. ArDERsos, of the Ameriman Agriculturist.

ITILI. BE GLADLI TELCOMED.-The copy of Prof. Scribner's book on Fungus Diseases has been receired. I wish to thank rou for the publication which I am sure will be gladls welcomed by fruit growers ererrwhere. The book will afford mans who do not read rour valuable paper a means of learning much that concerns them as tillers of the soil. $-B$. T. GALLOTAY, Chief of Division of Tegetable Pathology, $U$. S. Depl. of Agriculture.

PLAIN, SIMPLE AND ACCLRATE.-Few things of late rears hare put such a damper on the rinerardist as the grape-rot, and to the orchardist the scate. rot, and other diseases of the fruits of trees. In Prof. Scribner's book all these matters are discussed, explained. mith the proper remedies for the various erils, that it Will he ulain sailing bereafter if one goes to the littie trouble and expense necessary to carry out its instruetions. It is Iritten in that p'ain, simple, and accurate strle characteristic of all Prof. Scribner's productions with the pen. It should be in the hands of every horticulturist in the land.-SAMCEL MILLER

CONCISE, IXSTRTCTITE AND INTALCABLE. - Tour publication by F. Lamson-Seribner, "Fungus Diseases of the Grape and Other Plants, "is concise, instructire and inraluable to the practical fruit grower.-F. H. HILlyas, Entomologist and Botanist, Nevada Agrinutur il Experiment station. 
EVERY GROWER SHOULD HATE IT.-One of the greatest beneflts that has accrued to the cultivator from the establishment of the Hateh Experiment Stations has come from the facilities they bave afforded to speclaksts for the study of practical Botany workers should, like Huxley, regard Botony astan divisions of Biology, and in this way can produce of sults of practical and tions practical beneft to soll workers. Many stations have been fortunate in getting such men as Burrill, Scribner and others. A mere systematist in any is badly out of place in an experiment station and cannot produce the results which the gist does for the beneficto biolo tist does lor the benedt of those for whom these stations were intended. We ball therefore with pleasure any effort to place the results of practical botanical work before the mass of cultivators in such a shape that intelligent men, not botanists, can take hold of and apply in practice. Such an effort is before me in apshape of a littie volume by Prof. F. Lamson-Seribner entitled "Fungus Diseases of the Grapen-Scribner Plants." The effort manner the character of the to describe in a simple asitic plant life gener of the various low forms of pargest plant life generally known as fungl and to suggest remedles for them that have proved effective in practice. I wi ite not to criticise the effective in seems to me the best attempt ever me book, which ular line, but to express the bope thade in this particin the future go even further in that the author may very hard for go even further in the same line. It is very hard for any une accustomed to seientife work to realize how very simple he must make bis explanations when writing for general readers, and particularly for the cultivators of the soll. I do not mean to detract anything from the merits of this exceedingly valuable little book, but I am sure, as it is evidently 1 valuable unscientiflc readers, the value of a subsequent edition would be largely iucreased by the addition of a chapter explaining in the simplest manner possible the minute anatomy of vegetation and the physiolugical facts which separate fungi from treen physlolugical facts simple directions in the use of the plants, and also some merely thrown out as a sugrestion. This is present shape is admirable and grower of fruits admirable and I earnestly advise every grower of fruits to get a copy.-W. F. MASSEY, Professor of Horticulture and Botany. $N$. Colle. riculture and Mech.enic Arts; and . Cnlleye of $\mathrm{Ag}$ the Experiment Station.

TREATS IN A POPULAR STYLE.-I am greatly interested in Prof. Scribner's work on Fungus Diseases should be in the hands of every fruit grower for It treats of grape mildew, scab, etc in a popular for it that every one can understand them a popular style so dies with intellin understand them and apply remedies with intelligence, and yet in a sunflencly scientifle manner to satisfy the student. The study of these fungi bas become positively necessary to success in fruit culture, and the man who negleets it and the remedies prescribed will be far behind at barvest time. -L. WOOLY ERTON, secretary Ontario (Canada) Fruit Grouers' Association. 
HaILED TITH DELIGHT.-This work Tritten by one of our most able botanists and foremost authors on fungus diseases is copiously illustrated with original drawings from nature and "treats most extensively the fungus of the Grape as Well as the most important fungus diseases of the Apple, Pear, Peach, Plum, etc." He classifies and describes these different fungi in a concise and deflnite manner that any common observer may understand and recognize them. This book has been prepared for the vineyardist, orchardist and gardener and treats the subjects in a practical manner, giving the formulas, remedies and the wode of application. The most interesting and important part of the work is the result of the experiments by different individuals in various sections of the country showing beyond a doubt that if we cannot cure these different diseases we hare at least found a remedy by which we can successfully combat them and hold them in check so that we can produce a good crop of fruit. This work should be hailed with delight, and procured and read by every fruit grower, and should give a new impetus particularly to the grape grower, as he appears to have suffered more than his share, by these destructive fungi.-J. STA YMAN.

A GREAT SERTICE To FREIT GRotrers.-I have read with much interest Prof. Scribner's book "Fungus Diseases of the Grape and Other Plants," and am greatly pleased with it. There is no one subject that is now so generally attracting the attention of fruit growers than the subject of "spraying," as upon it at this time, more than upon any cther oue thing, depends our success, I commenced spraying my orchards of some flve thousand apple and pear trees tive years ago, and with increasing satisfaction each year. In my work of looking after horticultural interests in the Eleventh Census we have found that the grape growing industry of this country, which now has upwards of $\$ 155,000,000$ of capital invested, has turned as ucon a pivot from a depressed condition to that of a profitable investment in large sections of our country, on the results of " spraying" as prcmulgated so generally through the U.S. Department of Agriculture. Prof. Scribner by bringing all the details of this forward step together in such an attractive and practical form has rendered great service to fruit growers.-MORTIMER WHITEHEAD, Chief Special Agent U.S. Census of 1890.

A VALCABLE WORK. - I thank you for your courtesy in sending me a copy of Scribner's "Fungus Diseases of the Grape and Uther Plants." It is a valuable work. - JOSEPH HARRIS.

Clearly aND Thorocghly TREaTed.-Prof. Scribner's "Fungus Diseases of the Grape,etc." has been received and examined. I flnd the matter very clearly and thoroughly treated so that anyone of ordinary intelligence can understand it. A copy of it should be in the hands of every fruit grower, and thoroughly studied.-E. A. RIEHL, President Horticultural Society of Southern Illinois. 
DeSTINED TO REVOLUTIONIZk HoRTICUlture.-Please accept thanks for copy of Prof. Scribner's new work on Fungold Diseases, and a!low me to congratulate you, not only upon the fine typography and binding of the work, which are both nearly faultless, but especially upon giving to the horticultural world a work which is destined to revolutionize several branches of horticul ture. It would be easy to enlarge upon the particular merits of this book, but I would like to say a few words merely upon one phase of the subject and that is the flnancial effect of diffleulties and obstacles encountered in any pursuit. It may be safely laid down as a rule that the greater and more numerous these difficulties and obstacles are, the greater the protlt to those who succeed; and whenever any practical means of combating them are discovered those who avail themselves of these discoveries and use them to the best advant age are sure to make a financial success. The common potato furnishes a pertinent illustration. When potatoes grew almost spontaneously, and any farmer could readily grow all he had land and manure for, they afforded a valuable root food for stock at a small cost, but as a product for market they were uncertain and rarely very proftable, but since the rot and Colorado beetle have inade careless culture impracticable, the well-informed and thorough cultivator can be nearly certain to secure a liberal profit on this crop. I do not hesitate to predict that a similar result will follow in some of the fruits. A word to the wise is sufleient.WM. F. BASSETT.

AN ADMIRABLE TREATISE. - I am much obliged for the receipt of a cupy of Professor Scribner's book upon the "Fungus Diseases of the Grape and Other Plants"

It is indeed au admirable treatise, thoroughly scientific and yet so clear and simple that it will be understood by every cultivator. It is evident that a wonderful advance has been made within a very few years, both in understanding the nature of these diseases and the efficient remedies which will control them. While it is true that the enemies of fruit culture have largely increased within this generation, yet it is also true that our means of coping with these enemies are now so extended that the prospects of successiul and profltable results were never more encouraging than at the present time. For this result we are largely indebted to our selentifle investlyators.-WM. C. STRONG, Ex-President Mass. Horticultural Snciety.

DESERVES A WIDE CIRCULATION.-Accept my thanks for a copy of Prof.Scribner's book on "Fungus Diseases of the Grape and Other Plants." I have read it all through and am very glad to have it in this compact. form for ready reference. It ought to be very acceptable to every intelligent fruitgrower, and I sincerely hope it will meet with a wide circulation. It certainly deserves it; and you have done a very commendable work in bringing it out in such a shape. I trust you: may be amply rewarded.-E. WILLIAMS, Ex-Secretary New Jersey Horticultural Society. 


\section{OPINIONS OF THE PRESS,}

AN EXCELleNT MANUAL FOR THE FRUTT GROWRR. Mr. Lamison-Scribner who is a well known authority on the subject which he here treats,embodies in a book of some 150 pages a scientific account, in popular style, of several of the most troublesome fungi which prey upon our vines and fruit trees. The special subjects are the Black Rot, the Bitter Rot, the White Rot, the Brown Rot and the Powdery Mildew of the Grape, the Grape Leaf Blight the Root Rot of theVine. caused by two species of fungus, Anthracnose and Bird's Eye Rot of the Grape, Black Rot of the Apple, Apple Rust and Cedar Apples, Apple Scab, the Leaf Blight of the Pear, the Plum Rot, Black Knot of the Plum and Cherry, Leafspot Disease of the Plum and Cherry, Powdery Mildew of the Cherry, Peach-Leaf Curl, and Raspberry Anthracnose. These subjects are all carefu.ly considered, the fungi particularly described and the best mode of treatment indicated. The book is an excellent manual for the fruit grower, who should consult it and follow its advice.-Vick's Magazine.

THE WORK WELL PERFORMED-The want of a treatise of this kind has been long felt by the fruit-growers of America. Much useful information on the treatment of plant diseases has appeared from time to time in the Experiment Station and Department of Agriculture bulletins, but these publications are not available to the vast majority of fruit growers. In the book before us Professor Scribner has brought together into succinct form a full and plain account of all the diseases affecting grapes and other fruits in valious parts of the country, to which have been added simple directions for their treatment and ultimate eradication. After explaining very satisfactorily what fungi are, the various diseases of the grape root, vine, leaf, and fruit are fully considered, and, as the author is high authority on the subject, vineyardists need not hesitate to follow his directions. Nine diseases of the grape are thus elaborated. Next come the diseases of the apple, pear, quince, plum, cherry, peach, and raspberry. All the subjects discussed have been beautifully illustrated with drawings from nature by the author and they serve well the purpose of giving the reader an intelligent idea of the appearance of these minute yet terribly destructive parasitic plants. Both author and publishers have performed their work well, and every vineyardist and orchardist who fails to secure a copy of this treatise for daily reference will "miss it" when he comes to gather his fruits next fall.-American $\mathrm{Ag}$ riculturist,

FRUIT GROWERS SHOdLD POSSESS IT.-It is written in such plain language that the reader of ordinary intelligence can understand it and the illustrations, largely magnitied, show what a fleld of life there is in this part of the invisible world. Every careful and iutelligent fruit grower should possess this valuable handbook.-The Philadelphia Press. 
SHOWS THE BEST METHODS.-The knowledge of fungous diseases of plants has, within comparatively fewyears, been supplemented by so many yaluative experiments on the relative merits of different $\mathrm{ch}$ cals in checking their growth and by the inv chemlmachines for applyin town, and by the invention of machines for applying them in the most efficient way that there was need of a compact popular summary the subject for the use of farmers and summary of This is afforded by the little book of Prof. Scribner. which gives a popular account more esfecially of the principal rots, mildews, blights and other uiseases of the vine, followed by shorter chapters on various diseases. of apples, pears, cherries, plums, peaches aus diseases. ries. The main object of the author is and raspberbest method of applying remedies is to show the of the fungt whing remedies,and the descriptions. of the fungt which cause the various diseases are de. signed to enable thoso who are not well informed deregard to fungi to recognize with as little diffled with possible the distinctive characters of the differenty as eases as a preliminary step in app or the different disThe compass of The compass of the book prevents any extended account of the different fungi, but those which affect the grape are given with suffeient fulless cal purposes. A more extended introd for all praction the general characters of funtroductory chapter have served a useful purpose. A considerable however, of woodcuts give the gross and misonsiderable number of the fungi and the appliances for sprintling be regretted that the flgures a re utively, since the irregularity of thot numbered consecback referene numbering makes back reference difficult. The work is to be recommended to the large number of persons who need a summary of this imporiant subject wlth a view to making a practical application of the knowledge acquired.-Garden and Forest.

ThOROdGH,BRIEF, AND PRACTICAL. - Fungi have been subjects of special study with Prof. Scribner, and he is consequently one of the foremost autherities in country upou that subject. He treats gus diseases presented in this briefly and practically. subsequent practically. Their first appearance and subsequent development, down to the consummation of their evil work, are fully described in consummation. prehensiye terms, and the nature of each disease and means for its identification is given, with the remedies to be used and mode of application. He treats most extensively of fungus diseases of the grape but most the misty of fungus diseases of the grape, but also pear, peach, plum, quince, fungus diseases of the apple, which there are over 60 , etc. The illustrations, of stand, are all over 60 , are excellent, and, we underbook ar expressly for this book by pribner. The book contain 134 pages and a conveniently arranged index timely and valuable wirk arranged index. It is a by the large class of vin and we gladly welcomed who so much 
HIGH ACTHORITY ON THE SEBJECT.-The name of Prof. Scribner, at the outset gives authority to the work, and confdence in its teachings.-Farm Journal,

CONTENIENT AND TELL ILLCSTRATED.-An exhaustive treatment of fungus diseases of plants including the black rot of grapes, the white rot, the powdery mildew, leaf rot, anthracnose, black rot of the apple, apple rust, apple scab, pear scab, cracking of the pear and quince, plum rot, black knot, peach leaf curl, has been written by Prof. F. Lamson-Scribner in a convenient well i!lustrated little volume of 134 pages, with a profuse index. - New England Furmer.

COMPLETE WORK ON THE SEBJECT.--"Fungus Diseases of the Grape and Other Plants," is the name of a new work by Prof. Scrioner whose name is sufflcient to recommend it. It adds another volume of great usefnlness to my horticultural library. It is a complete work on the subject upon which it treats, and gives us the means of combating one of the worst enemies we have, successfully. It should be in the hands of every fruit grower and gardener.-Colman's Rural World.

OF GREAT USE.-A duodecimo book of 134 pages, on the "Fungous Diseases of the Grape and Other Plants," prepared by Prof. F. Lamson-Scribner, bas been recently published by J. T. Lovett Company, Littie Silver, N. J. Now that cultivators have met with so many diseases of trees and plants, this compact manual for ready reference will be found of great convenience in distinctly pointing them out and applying known remedies, and in reducing the confusion occasioned by the prevalence of these diseases, to the accuracy of science and distinct description. The following are most of the diseases treated: Black rot and brown rot of the grape: powdery mildew of the vine; black knot and plum rot, apple scab and apple rust; black rot of the apple and bitter rot; cracking of the pear; peach leaf curl; raspberry rust; leaf blight of the pear, and powdery mildew of the cherry. All are fully illustrated. An introductory chapter on general principles serves to render the subject easily understood. In a few instances a little additional information might be added, as for instance the value of a thrifty growth to prevent peach-leaf curl, and to the unscientiflc reader an explanation of the word "anthracnose," which is frequently used might be acceptable. On the whole, however, it will be found of great use for garden and feld reference-The Country Gentleman. 


\section{THE TRUE GRASSES.}

BY EDWARD HACKEL.

Translated from die naturlichen Pflanzenfamilien by F. LAMSON-SCRIBNER and E. A. SOUTHWORTH.

8 vo. 228 pp. Copiously illustrated.

What is said of THE TRCE GRASSES,

It is a treasure to me and ought to be well studied by every student of flowering plants, whether he be a systematist who strives to collect, name and classify, or the plant anatomist."-DR. W. J. BEAL, Prof. of Botany and Forestry at the Michigan Agric. Colleye.

It is a most useful and timely work, and will be of great value to us in the course of instruction which we offer here on the order Gramineæ.-A. N. PRENTISS, Professor of Botany at the Cornell University.

Among all the works hitherto published upon this subject, Prof. Hackel's book ranks as undoubtedly the most comprehensive. The translation has been done in a manner that makes it not only pleasant reading, but also interesting to scientific students and easily understood in practical use.-THEO. HOLM, in Botanical Gazette.

For students of grasses this work must possess great interest and value. The fllustrations are excellent and will be a great ald to the understanding of the technical descriptions. The remarks made in the volume, respecting the habits and economic uses of certain grasses are of great interest.-GEO. VASEY, Botanist U. S. Department Agriculture.

This translation presents to English readers the first concise and methodical account of the Grasses of the world. Dr. Hackel is known as one of the best living agrostologists, and Prof. Scribner is well known in the same fleld in this country. It enables the student to grasp the whole subject and to arrive at comparative knowledge, while at the same time its keys and detafls are ample enough to give a somewhat particular view of each genus. The chapter upon Bamboos, contributed by Dr. Brandis, is one of the best presentations of this interesting group yet written.-A mericanGarden.

The translators have combined a thorough understanding of techinal German with a special knowledge of grasses, and the resulting translaiton is accurate, clear and scientifleally correct.-Bulletin of the Torrey Botanical Club.

The work will be valuable to all who are studying the grasses.-Gardener's Chronicle.

American agrostologists are certainly indebted to Prof. Scribner and Miss Southworth for the translation before us. Every effort was made to make this volume not only a correct translation, but a helpful one to American students. The index and glossary is exceptional in its completeness. The book is a splendid piece of typographical work.-Agricultural Science.

Price $\$ 1.50$, by mall postpaid.

\section{J. T. LOVETT CO., Little Silver, N. J.}




\section{(2)RCHARDD ${ }^{\circ}$ GARDEN}

A National Journal of Horticulture.

Illustrated and Published Monthly.

Devoted to the interest of American Fruit-growing and Gardening. The brightest and most thoroughly practical horticultural journal published. Ahead of all other papers of the kind in originality, reliability and practical solid sense. Everybody should read it. It tells you how to make your garden profltable. Its writers are among the foremost horticulturists and scientists on this continent, and every article is written by a specialist in the subject of which he treats. Its departments are:

THE ORCHARD.-Our staple fruits are dealt with under this heading. The planting of orchards, culture and pruning of the trees: marketing and storing of the fruit, etc,, etc.

THE VINEYARD.-The merits of new varieties are faithfully reported; new methods of culture discussed and the experience of practical growers interchanged.

THE VEGETABLE GARDEN. -Devoted not only to the home garden but also to the interest of the market gardeners, North and South. Best varieties and best methods of culture are fully discussed.

THE BERRY PATCH.-The small fruits are here treated exhaustively - new varieties, planting, culture, marketing, etc., are given special attention.

NUTS AND NUT TREES. - We give special prominence to this industry, believing it to be one of the most profltable and with a big future.

INSECTS. - The special pests of the horticulturist are flgured and described, and remedies suggested.

THE FLOWER GARDEN. - Full particulars regarding the management of flowers are given; new and valuable sorts illustrated and described, etc.

THE LAWN AND PARK. - The ornamentation of home grounds, treatment of ornamental trees and shrubs is here given.

THE HOUSEHOLD. - Every housewife may find something useful in this department; domestic economy, hints and suggestions, etc.. ete.

Reports of Horticultural Societies, Editorial Comments, \&c., \&c., all combine to make it the most helpful and practical Journal of the kind published. Written, Edited and Published by Practical Horticulturists.

Fifty Cents a Year

or Three Months on trial for only ten cents. Sample copies free. Address

J. T. LOVETT CO.,

Witte Silver, Monmouth Co.,NewJersey. 


\section{ORCHARD \& GARDEN}

\section{PREMIUMS FOR FALL 1891.}

To anyone in GARDer alone is posite page). It $i$ ing its circulatio are enabled to of and greatly incre lots of Tress and January 1st 1892:

No. $1 . \quad$ Six LovetT's b

No. 2. Three BEEBE STRA

No. 3. Six PARKER EARLE,

No. 4. Three LOVETT or $\$ 100$

berries. (See page 12).

No. 5. Twelve THOMPSON's EAI

(See page 13).

No. 6. Six IMPROved DwARF J

No. 7. Three CRANDall CURRA

fruit. (See page 20).

No. 8. Two Childs' Great Jay

No. 9. Two Childs' Everbeay

No. 10. One LovetT's Best B

No. 11. One Moore's Diamo

No. 12. Two LovetT's WH

No. 13. Three WONDERF'

No. 14. Carlovgh AP'

No. 15. One IDAHo -

No. 16. One Lind

No. 17. Two ABU

No. 18. One ACM!

No. 19. Troo HARI

No. 20. T20o JAPA

Any body stond lots enumerated ab may select any one journal for a whole
Acme Library Card Pocket

Made by LIBRARY BUREAU

146 FrankLin St., Boston

Keep Your Card In This Pocket
'E.

Ire ORCHARD AND uncement on opment and extendI list increases we a view to quickly If the following its for it prior to

arly variety

(See page 4.)

f all black Rasp-

ırly red variety.

most interesting

7).

y extant.

(See page 23.)

(See page 33.)

colored plate). longest keeper.

of plums.

y; an anomely.

e North.

rolific bearing.

$e$ of the twenty and two dollars, ind send also the -subscribers, the clubraiser may select two luv ana receive the journal a year free, and so on for every three additional subscribers (always at fifty cents each, he $\mathrm{m}$ y select an additional lot from the above list of twenty lots; each subscriber receiving any one of the lots also, as may be chosen by him or her. In sending subscriptions and calling for the plants etc., offered as premiums, it will be necessary to refer to the numbers only-as preminum No. 1 , No. 5 , or No. 10.

Of course those who receive the journal as a preminum to a club order of Trees and Plants as offered elsewhere, cannot call for any of the preminums here offered to subscribers but, for the journal only-these premiums being extended exclusively to cash subscribers and club raisers.

MONRY ORDER OFYICE,

RED BANE, N. J.

J. T. LOVETT CO., Little Silver, N. J. 


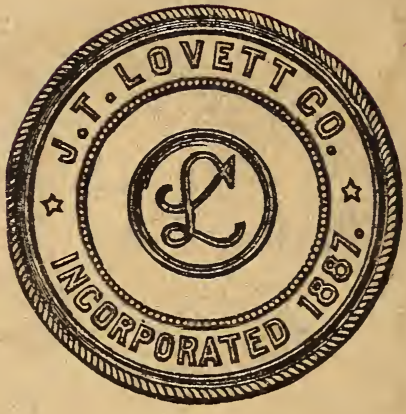




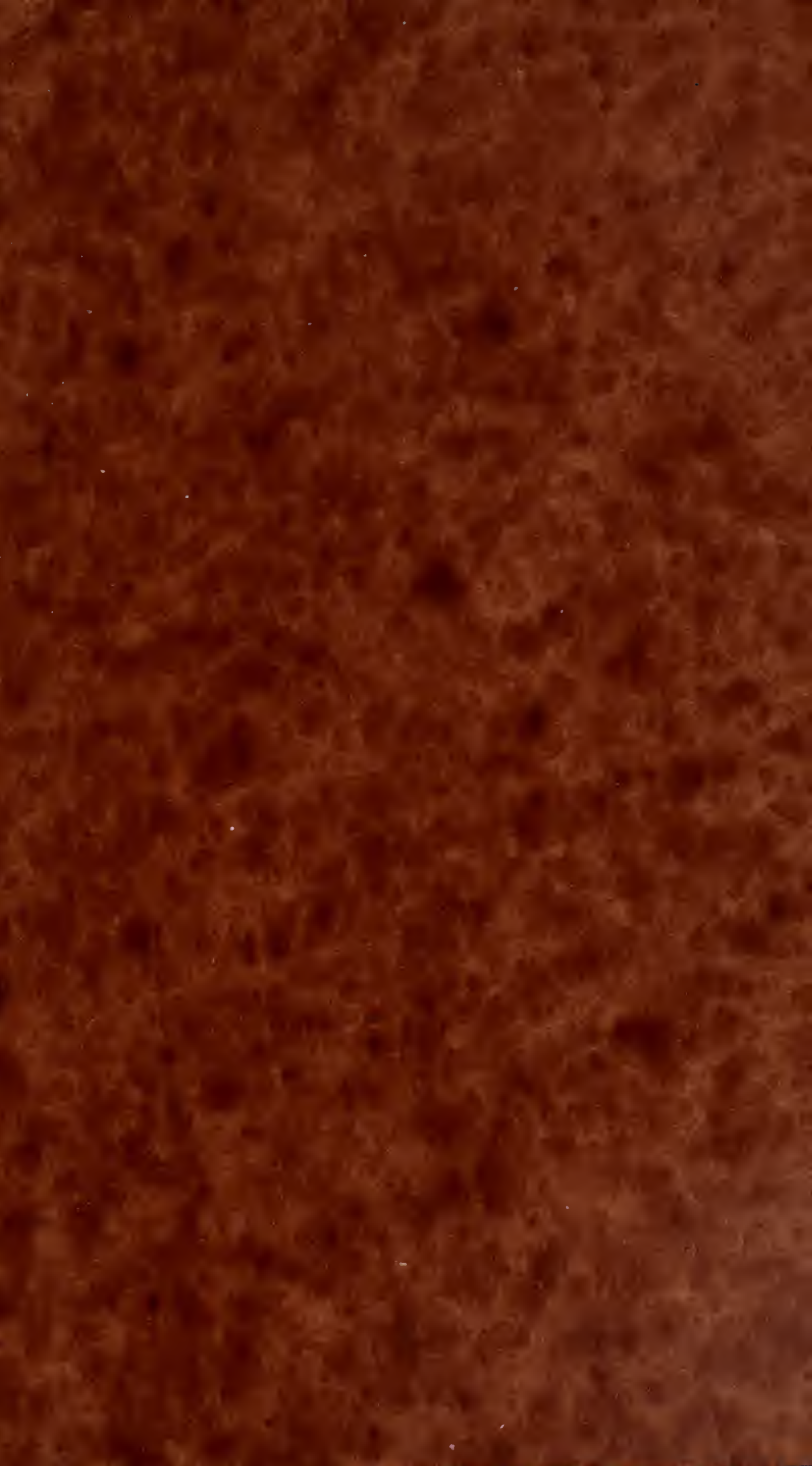


